\title{
Renal cell carcinoma : risk factors and von Hippel- Lindau gene mutations
}

Citation for published version (APA):

van Dijk, B. A. C. (2006). Renal cell carcinoma : risk factors and von Hippel-Lindau gene mutations. [Doctoral Thesis, Maastricht University]. Universitaire Pers Maastricht. https://doi.org/10.26481/dis.20060217bd

Document status and date:

Published: 01/01/2006

DOI:

10.26481/dis.20060217bd

Document Version:

Publisher's PDF, also known as Version of record

\section{Please check the document version of this publication:}

- A submitted manuscript is the version of the article upon submission and before peer-review. There can be important differences between the submitted version and the official published version of record.

People interested in the research are advised to contact the author for the final version of the publication, or visit the DOI to the publisher's website.

- The final author version and the galley proof are versions of the publication after peer review.

- The final published version features the final layout of the paper including the volume, issue and page numbers.

Link to publication

\footnotetext{
General rights rights.

- You may freely distribute the URL identifying the publication in the public portal. please follow below link for the End User Agreement:

www.umlib.nl/taverne-license

Take down policy

If you believe that this document breaches copyright please contact us at:

repository@maastrichtuniversity.nl

providing details and we will investigate your claim.
}

Copyright and moral rights for the publications made accessible in the public portal are retained by the authors and/or other copyright owners and it is a condition of accessing publications that users recognise and abide by the legal requirements associated with these

- Users may download and print one copy of any publication from the public portal for the purpose of private study or research.

- You may not further distribute the material or use it for any profit-making activity or commercial gain

If the publication is distributed under the terms of Article $25 \mathrm{fa}$ of the Dutch Copyright Act, indicated by the "Taverne" license above, 


\section{Renal Cell Carcinoma}

Risk factors and von Hippel-Lindau gene mutations 
Renal Cell Carcinoma. Risk factors and von Hippel-Lindau gene mutations. Boukje Annemarie Cornelia van Dijk

$$
\text { ISBN: } \quad 90-5278-508-2
$$

Universitaire Pers Maastricht

Cover Kachung Tsang

Lay-out Tiny Wouters

Printed by Datawyse

2006, Boukje van Dijk

All rights reserved. No part of this thesis may be reproduced or transmitted in any form or by any means, electronic or mechanical, including photocopying, recording or any information storage or retrieval system without permission in writing from the author, or, when appropriate, from the publisher of the publications. 


\section{Renal Cell Carcinoma}

Risk factors and von Hippel-Lindau gene mutations

\section{PROEFSCHRIFT}

ter verkrijging van de graad van doctor

aan de Universiteit Maastricht,

op gezag van de Rector Magnificus,

Prof. mr. G.P.M.F. Mols,

volgens het besluit van het College van Decanen,

in het openbaar te verdedigen

op vrijdag 17 februari 2006 om 14.00 uur

door

Boukje Annemarie Cornelia van Dijk

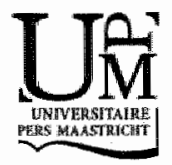




\section{Promotores}

Prof. dr. ir. P.A. van den Brandt

Prof. dr. J.A. Schalken (UMC St. Radboud)

\section{Co-promator}

Dr. L.J. Schouten

\section{Beoordelingscomminsie}

Prof. dr. Ph. Lambin (voorzitter)

Prof dr. A.H.M. Geurts van Kessel (UMC St. Radboud)

Dr. G.O.N. Oosterhof

Dr. P.H.M. Peeters (UMC Utrecht)

Prof. dr. F.I. van Schooten
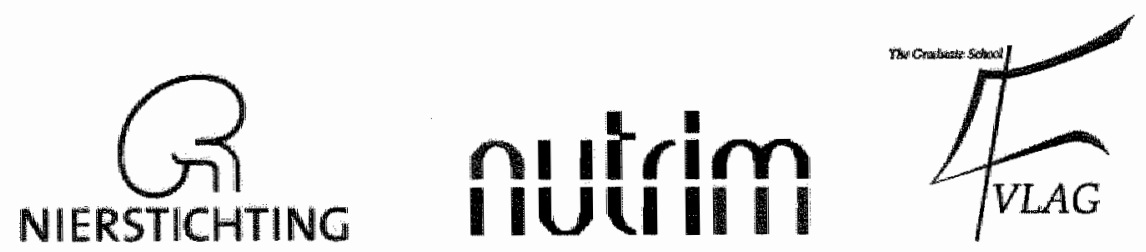

This project was funded by a grant from the Dutch Kidney foundation (C99.1863).

The studies presented in this thesis were conducted at Maastricht University, at the Department of Epidennology, Nutrition and Toxicology Research Institute Maastricht (NUTRIM), which participates in the Graduate School VLAG-2 (Fond Technology, Agrobiotechnology, Nutrition and Health sciences) accredited by the Royal Netherlands Academy of Arts and Sciences (KNAW), and the Departments of Urology and Pathology, UMC St Radboud, Nijmegen

Financial support for the printing of this thesis was kindly provided by the Dutch Kidney foundation and the Department of Epidemiology (Maastricht University). 
Voor pap en mam 



\section{Contents}

Chapter 1 Introduction

Chapter 2 Relation of height, body mass, energy intake, physical activity to risk of renal cell carcinoma: results from the Netherlands cohort study Am J Epid 2004; 160(12):1159-67

Chapter 3 Vegetable and fruit consumption and risk of renal cell carcinoma: results from the Netherlands cohort study

Int J Cancer 2005; 117(4):648-54

Chapter 4 Prevalence of von Hippel-Lindau gene mutations in sporadic renal cell carcinoma: results from the Netherlands cohort study BMC Cancer 2005;5:57

Chapter 5 Cigarette smoking, von Hippel-Lindau gene mutations and sporadic renal cell carcinoma

Submitted for publication

Chapter 6 Hypertension, antihypertensives and mutations in the von Hippel-Lindau gene in renal cell carcinoma: results from the Netherlands cohort study

$J$ Hypertension 2005;23(11):1997-2004

Chapter 7 Carotenoid and vitamin intake, von Hippel-Lindau gene mutations and sporadic renal cell carcinoma: results from the Netherlands coloort study

Submitted for publication

Chapter 8 General discussion

Summary

Samenvatting

Dankwoord

About the author 
1

Introduction 
Kidney cancer includes cancer of the renal parenchyma (Renal Cell Carcinoma (RCC)) and cancer of the renal pelvis. These two different types of cancer not only differ with respect to anatomical location and the type of cell from which these evolve (parenchymal cells versus urothelial cellls, respectively), but also with respect to their association with risk factors. Unfortinately, the distinction is not always made, as is the case for most descriptive rates of kidney cancer.

\section{Descriptive epidemiology}

Kidney cancer (including cancer of the renal pelvis) is the ninth most common cancer in the European Union'. Incidence and mortality rates for 2002 are shown in Table 1.1. These are approximately twice as high for men as for women ${ }^{1,2}$.

Table 1.1 Age standardized (world) incidence and mortality rates (ASR(W)) per 100,000 person years for kidiney caneer -2002.

\begin{tabular}{lccccc}
\hline Country/region & \multicolumn{2}{c}{ Men } & & \multicolumn{2}{c}{ Women } \\
\cline { 2 - 3 } & $\begin{array}{r}\text { Incidence } \\
\text { (ASR(W)) }\end{array}$ & $\begin{array}{c}\text { Mortality } \\
\text { (ASR(W) }\end{array}$ & & $\begin{array}{c}\text { Incidence } \\
\text { (ASR(W) }\end{array}$ & $\begin{array}{c}\text { Mortality } \\
\text { (ASR (W)) }\end{array}$ \\
\hline World & 4.7 & 2.3 & & 2.5 & 1.2 \\
More developed regions & 10.4 & 4.6 & & 5.0 & 2.1 \\
Less developed regions & 2.1 & 1.2 & & 1.2 & 0.7 \\
Northern America & 12.6 & 4.1 & & 5.9 & 2.0 \\
Western Europe & 11.3 & 5.2 & & 5.4 & 2.5 \\
The Netherlands & 9.8 & 5.5 & & 4.9 & 2.7 \\
\hline
\end{tabular}

Source: http: $/ /$ www-dep. iarc.fr ${ }^{2}$

Also, incidence and mortality rates are clearly higher for more developed regions, including The Netherlands, than for less developed regions ${ }^{2}$. In some parts of the world an increase in incidence of kidney cancer has been reported ${ }^{3-6}$, but in The Netherlands the incidence of kidney cancer (excluding cancer of the renal pelvis) remained stable ${ }^{7}$. This reported increase in incidence may partly be due to an increase in abdominal imaging use ${ }^{3-6}$, resulting in a larger number of incidentally discovered RCC. If this were the case, one would expect this increase to occur specifically in small, localized tumors. In a report by Hock et al, an increase in the percentage of localized tumors was observed in the period from 1986 through 1998 compared to the period of 1973 through 1985, but this was not statistically significant ${ }^{3}$. In that study, the annual percent change in incidence rate was also considered and this rate increased in localized, regionally advanced and distant tumors with the highest increase in the localized group ${ }^{3}$. Trends in mortality rates show a non-significant decrease ${ }^{4}$, but in the Netherlands no change in mortality rate for kidney cancer, excluding cancer of the renal pelvis, was observed ${ }^{7}$. The possible decrease in mortality rates may be the result 
of an increase in 5-year survival. European estimates for 5-year survival have increased from approximately $40 \%{ }^{8}$ for patients diagnosed in 1978-1980 to approximately $55 \%$ for patients diagnosed in 1990-1994. Generally, this may reflect better treatment or the treatment being more effective because the cancer was diagnosed at an earlier stage ${ }^{8}$.

\section{Pathology and genetics}

We confined our research to cancer of the renal parenchyma, RCC, which can be subdivided into several histological types. The most common histological subtype is clear-cell or conventional RCC, which accounts for approximately $75 \%$ of renal cell. neoplasms in surgical series ${ }^{10}$. This tumor is characterized by clear cytoplasm, hence the name clear-cell $\mathrm{RCC}^{10}$. The other subtypes are papillary RCC, chromophobe RCC, collecting duct carcinoma and unclassified RCC.

Specific genetic alterations have been linked to each of these histological subtypes. Aberrations in the von Hippel-Lindan (VHL) gene have been shown to be an early and distinct event in the development of clear-cell $\mathrm{RCC}^{11}$. The $V H L$ gene was identified after molecular research of DNA from patients with Von Hippel-Lindau disease, a hereditary syndrome that predisposes to, amongst others, clear-cell RCC. Allelic imbalance was frequently observed at $3 \mathrm{p} 25-26^{12-14}$. The corresponding gene was characterized as a tumor suppressor gene and named the won Hippel-Lindau gene $\mathrm{e}^{14,15}$. The $V H L$ gene is composed of 3 exons.

$V H L$ gene mutations have been observed in $56-69 \%$ of sporadic (non-hereditary) clearcell $\mathrm{RCCs}^{14}$. Mutations usually lead to a shortened inactive protein. The VHL protein may also be absent as a result of hypermethylation of the promotor area. This is estimated to occur in approximately $15-19 \%$ of sporadic clear-cell $\mathrm{RCCs}^{14,16}$. Since the VHL gene is a tumor suppressor gene, both alleles need to be affected before it loses its function. Loss of heterozygosity (LOH) is common and inactivates one allele. LOH has been reported to occur in $74 \%{ }^{17}$ to $93 \%$ of tumors. Kondo et al. showed $97 \%$ LOH in mutated or hypermethylated samples compared to $81 \% \mathrm{LOH}$ in wildtype samples ${ }^{19}$. The non-mutated human $V H L$ gene is translated into two wildtype VHL proteins: pVHL 30 and pVHL1 $9^{20,21}$. Both proteins are capable of suppressing tumor formation ${ }^{21}$. Under normal oxygen conditions, $\mathrm{pVHL}$ forms a complex with elongin $\mathrm{B}$, elongin $\mathrm{C}$ and cullin 2 proteins ${ }^{14,20}$, which promotes ubiquitin-mediated proteasomal degradation of hypoxia inducible factor (HIF). Loss of pVHL leads to an active HIF complex, which binds to the hypoxia-responsive elements within the promoter/enhancer of hypoxia inducible genes, thus activating hypoxia-inducible genes ${ }^{14,20}$, even under normal oxygen conditions. The result is angiogenesis (blood vessel formation), which is necessary for solid tumors to grow larger than 1-2 $\mathrm{mm}^{3}{ }^{13}$. In addition, VHL expression can restore the ability of RCC cell lines to exit the cell cycle and enter G0 quiescence upon serum withdrawal in culture ${ }^{22}$. pVHL30 has an additional role in the assembly of extracellullar fibronectin matrix ${ }^{20,21}$. Loss of pVHL function, i.e. loss of 
regulation of hypoxia inducible factors, no promotion of "cell cycle exit", and no promotion of correct formation of the fibronectin extracellular matrix ${ }^{14}$, creates an environment favorable for tumor growth. A clear summary of possible interactions and functions of the wildtype VHL protein is given in a review by Richards ${ }^{14}$.

\section{Risk factors}

Many risk factors have been investigated in association with RCC risk. Some risk factors, such as cigarette smoking ${ }^{23-26}$, obesity ${ }^{23-27}$ and a history of hypertension and/or use of anti-hypertensive medication ${ }^{23,25}$, were consistently reported to be positively associated with $\mathrm{RCC}$ risk, although rate ratios (RRs) were only moderately increased. Reports on other risk factors showed less consistent associations with RCC risk. A literature overview of risk factors, for which their association with RCC was investigated, is given in Table 1.2 .

In the following sections, some details for risk factors that are consistently linked to RCC risk are discussed.

A recent meta-analysis of 19 case-control studies and 5 cohort studies on cigarette smoking in relation to RCC concluded that inhaled tobacco smoke is clearly implicated in the etiology of RCC. Risk was increased for former (RR: $1.21 ; 95 \%$ confidence interval (CI): $1.07-1.36)$ and current (RR: $1.45 ; 95 \% \mathrm{CI}: 1.26-1.66)$ smokers with a strong dose-dependent increase in risk ${ }^{28}$. Population-based attributable risks indicate that approximately $20 \%$ to $30 \%$ of RCC among men and $10 \%$ to $20 \%$ among women can be accounted for by cigarette smoking ${ }^{23,24}$. Also, it was shown that cigarette smoke metabolites can cause mutations in human DNA, which is not restricted to tissues directly exposed to tobacco smoke ${ }^{29}$. Cigarette smoke metabolites were found in the urine of smokers ${ }^{30}$, implying exposure of the kidney to mutagenic cigarette smoke metabolites.

Body mass index (BMI), the ratio of weight $(\mathrm{kg})$ to the square of height $\left(\mathrm{m}^{2}\right)$, is believed to be an important risk factor for RCC. In a meta-analysis of 4 cohort studies, 8 population-based case control studies and 3 hospital-based case control studies, a summary RR of $1.07(95 \% \mathrm{CI}: 1.05-1.09)$ per $1 \mathrm{~kg} / \mathrm{m}^{2}$ increase in BMI was found for men and women together ${ }^{31}$. The attributable proportion of RCC for excess body weight is estimated to be $25 \%$ for both men and women in the European Union ${ }^{32}$.

Hypertension and use of diuretics or other antihypertensive medication appeared to be risk factors for RCC in many epidemiological studies ${ }^{33,34}$. In a meta-analysis, a pooled adjusted odds ratio (OR) of $1.75(95 \% \mathrm{CI}: 1.61-1.90)$ was calculated for the association of hypertension, defined as a systolic blood pressure greater than or equal to $160 \mathrm{~mm}$ $\mathrm{Hg}$, and $\mathrm{RCC}^{33}$. This pooled OR did not include prospective cohort studies, which also found increased risks of RCC with increasing blood pressure ${ }^{35-38}$. For diuretic use, a pooled OR of $1.55(95 \% \mathrm{CI}: 1.42-1.77)$ was found based on case-control studies only ${ }^{34}$. Three cohort studies were also suggestive of an association between diuretic use and 
$\mathrm{RCC}^{39-41}$ " However, it is unclear whether hypertension and antihypertensive medication, specifically diuretics, or just one of these factors is responsible for the increased risk. Some recent studies showed that diuretic medication was no longer a risk factor after controlling adequately for the diagnosis of hypertension ${ }^{42,43}$, which suggests that not medication but hypertension itself is a risk factor for $\mathrm{RCC}$.

Table 1.2 Literature overview of risk factors for renal cell carcinoma $(\mathrm{RCC})^{\mathrm{a}}$.

\begin{tabular}{|c|c|}
\hline Factors consistently linked to RCC risk & Direction of association \\
\hline Cigarette smoking & + \\
\hline Obesity & + \\
\hline History of hypertension & + \\
\hline Diuretic use & + \\
\hline Factors inconsistently linked to $\mathrm{RCC}$ risk & Direction of association ${ }^{\text {t }}$ \\
\hline Vegetable and fruit consumption & - \\
\hline Micronutrient and vitamin intake & - \\
\hline Dairy product consumption & + \\
\hline Protein intake & + \\
\hline Fat intake & + \\
\hline Meat consumption & + \\
\hline Alcohol consumption & - \\
\hline Coffee drinking & $+1-$ \\
\hline Tea drinking & $+\%$ \\
\hline Physical activity & - \\
\hline Occupational exposure to asbestos & + \\
\hline Occupational exposure to polycyclic aromatic hydrocarbons & + \\
\hline Occupational exposure to gasoline and other petroleum products & + \\
\hline Occupational exposure to solvents, such as trichloroethylene & + \\
\hline Exposure to radiation & + \\
\hline Exposure to heavy metals (e.g., cadmium) & + \\
\hline Oral contraceptiwe use & * \\
\hline Estrogen replacement therapy & + \\
\hline Increasing parity & + \\
\hline Age at menarche & - \\
\hline Age at first birth & - \\
\hline History of hysterectomy / oophorectomy & + \\
\hline Analgesic use & + \\
\hline Acquired cystic disease & + \\
\hline Kidney siones & + \\
\hline Urinary tract infection & + \\
\hline Diabetes & + \\
\hline Low socioeconomic status & to \\
\hline
\end{tabular}

${ }^{a}$ This table is based on several reviews ${ }^{23-27} ;^{b}+$ Positive association, - Negative association.

In the following sections, some details for risk factors inconsistently reported to be associated to $\mathrm{RCC}$ risk are given. 
Dietary factors have also been investigated in association with RCC; positive asssociations were reported for dairy products, intake of protein and fat, and meat while inverse associations were reponted for vegetable and fruit consumption, intake of dietary antioxidants; and alcohol consumption ${ }^{22-26}$.

$\mathrm{RCC}$ is not generally thought of as an occupationally induced tumor, but the associations of a large number of occupational factors to $\mathrm{RCC}$ have been investigated. Workers exposed to degreasing agents and solvents (e.g., trichloroethylene) have been reported to be at increased risk for $\mathrm{RCC}$, but the results are inconsistent ${ }^{23-26}$ "Also, exposure to some specific occupational risk factors, such as asbestos, gasoline and other petroleum products, hydrocarbons, lead, and cadmium have been associated to an increased $\mathrm{RCC}$ risk $^{23-26}$,

There have also been some reports on the association of reproductive factors to $R C C$, but no convincing consistent results have been observed ${ }^{24,25}$.

\section{Rationale for this study}

As has been shown in the previous section, associations between risk factors and RCC risk remain weak or inconsistent. Mechanisms linking risk factors to DNA damage, which may ultimately lead to a tumor, have been described for several risk factors. However, the endpoint $\mathrm{RCC}$, which is commonly used, is heterogeneous in that $\mathrm{RCCs}$ differ in histology and in the presence of DNA mutations. Therefore, stratified analyses based on histology and the mutational status of a tumor may lead to additional insight in the carcinogenesis process. In that respect, clear-cell RCC and the presence of $W H L$ gene mutations are a suitable endpoint to study in association to risk factors, since clear-cell RCC is the most common histological subtype and mutations in the $W H L$ gene are an early event in clear-cell renal cell carcinogenesis. This is shown by the high frequency of observed $V H L$ gene mutations in clear-cell RCC and the presence of these mutations in all stages. If heterogeneous results are observed, these may serve as a clue for fundamental etiological processes in the carcinogenesis of clear-cell RCC.

Thus far, only two studies have linked risk factors to the presence of VHL gene mutations. The first was a case-control study by the group of Brauch et $a l^{4,45}$, the other was a case-only study by Hemminki et $a^{16}$.

The group of Brauch et al. conducted a case-control study to investigate whether trichloroethylene exposure produced RCC through a specific mutational effect on the VHL gene ${ }^{44}$. Thirty-three of $44(75 \%)$ RCC cases with occupational exposure to trichloroethylene presented with at least one $V H L$ gene mutation, in comparison to 42 out of $73(58 \%)$ of the RCC cases not occupationally exposed to trichloroethylene. In the group of cases occupationally exposed to trichloroethylene, a specific mutation was observed in 13/33 (39\%) of mutations. This $\mathrm{C}>\mathrm{T}$ missense mutation at nucleotide 454 , changing a proline to a serine within the VHL protein at codon 81 , was not observed in lymphocyte DNA from these patients or from 97 control individuals without RCC. This 
mutation was also not present in tumor DNA from $107 \mathrm{RCC}$ cases, not occupationally exposed to trichloroethylene, indicating specificity ${ }^{4}$. In an additional study on partly the same patients and a non-exposed control group, no differences in tumor type, grade and stage were observed, but trichloroethylene exposed patients were diagnosed at a statistically significantly younger age than non-exposed patients. $F H L$ gene mutations were observed in $14 / 17(82 \%)$ tumors of exposed RCC cases, compared to $2 / 21(10 \%)$ tumors of the non-exposed group RCC cases, but $V H L$ gene mutation analyses were hampered by technical problems related to the quality of archival DNA ${ }^{45}$.

Hemminki et al. obtained detailled exposure information through a personal interview using a structured questionnaire and DNA from archival paraffin-embedded material for 102 male patients with RCC. Forty-seven of 102 (46\%) patients presented with at least one mutation. Consumption of vegetables was associated with a decreased frequency of WHL gene mutations among smokers, while citrus fruit consumption was associated with a decreased frequency of $V H L$ gene mutations among all patients. The authors concluded that these results provide evidence that vegetable and citrus fruit consumption protect the renal VHL gene from mutational insults, although chance findings could not be ruled out ${ }^{46}$. Additionally, it has to be noted that all investigated persons were diagnosed with $\mathrm{RCC}$, so no comparison to the level of: vegetable and citrus fruit consumption in the general population could be made.

\section{Aim of the study}

To investigate the associations of several risk factors and RCC risk, and to further investigate these associations by redefining the endpoint based on histology and $V H L$ gene mutational status.

\section{Study design}

Data from the Netherlands cohort study on diet and cancer (NLCS), a large nationwide population-based cohort study that started in 1986 in a joined effort by Maastricht University and TNO Nutrition and Food Research ${ }^{47}$, was used. In the design phase, an effort was undertaken to reduce loss to follow-up to a minimum, by choosing areas with a good coverage by the National Cancer Registry and PALGA, a nationwide pathology database ${ }^{48}$. Linkage to the PALGA database also gave us the unique opportumity to use paraffin embedded tumor material, since the location of paraffin material was recorded in this database. Paraffin material from 51 pathology laboratories was used to review histology and investigate the mutational status of RCCs, which enabled us to further define the endpoint for analyses. 
The study design of The Netherlands cohort study, including collection of paraffin material and statistical analyses, as carried out in the present study, is shown in Figure 1.1.

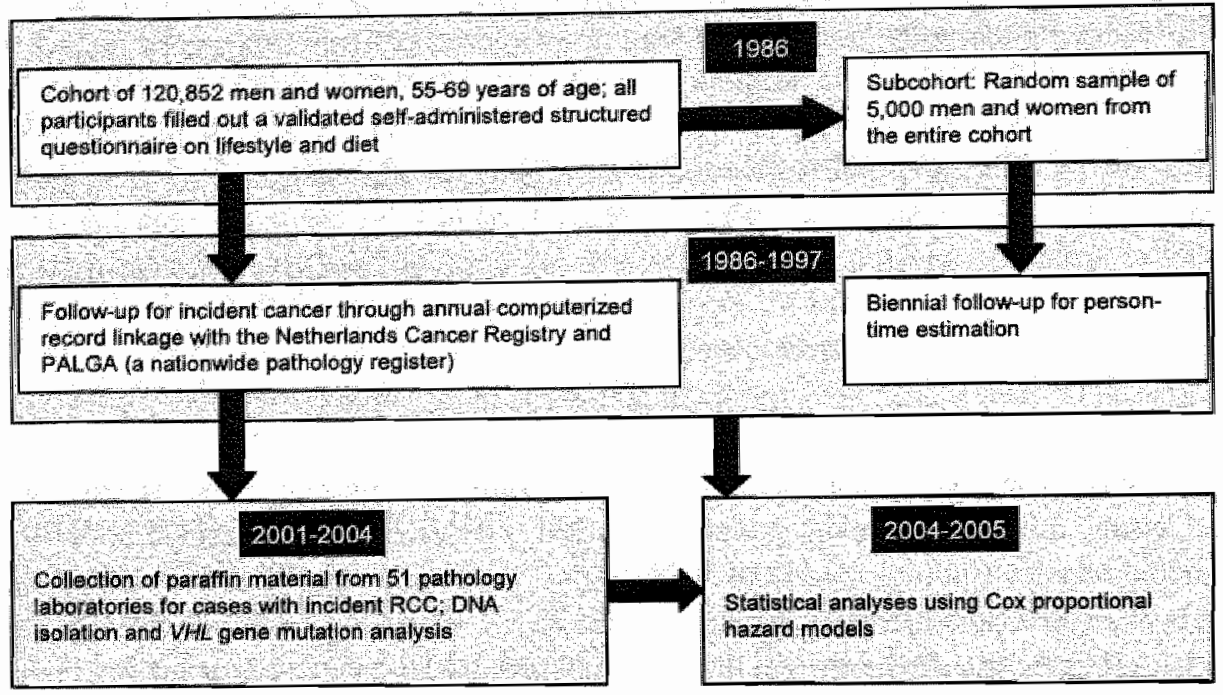

Figure 1.1 Study design - Netherlands cohort study on diet and cancer.

A case-cohort approach was used, which means that cases were enumerated for the entire cohort, while the person-time accumulated in the entire cohort was estimated using a subcohort of 5,000 men and women, which was randomly drawn from the entire cohort at baseline. After 11.3 years of follow-up 337 incident cases were observed. In this thesis, we focus on clear-cell $\mathrm{RCC}$ because this is the most common subtype of RCC, and will therefore generate a sufficiently large number of cases to investigate associations with risk factors. Additionally, aberrations in the VHL gene are an early and distinct event in the development of clear-cell RCC.

\section{Outline of this thesis}

In the next two chapters (chapters 2 and 3) associations between risk factors and RCC risk are described. The association between anthropometric variables and RCC risk is explored in chapter 2, which additionally includes information on energy intake and physical activity. In chapter 3 , the association of vegetable and fruit consumption and RCC risk is described. Chapter 4 describes the collection of paraffin material, methods and results of VHL gene mutations analysis, and the association of mutations with clinical/pathological parameters. In chapters 5,6 , and 7 the relation of cigarette smoking, hypertension and use of antihypertensive medication, and carotenoid and 
vitamin intake and RCC risk and $V H L$ gene mutations are described, respectively. Finally, in chapter 8, main findings, strengths and limitations, implications of analyses including VHL gene mutations, conclusions, and suggestions for further research are discussed. 


\section{References}

1. Ferlay J, Bray F, Sankila R, Parkin D. EUCAN: Cancer Incidence, Mortality and Prevalence in the European Union 1998, version 5.0. Lyon: LARCPress., 1999.

2. Ferlay $J_{\text {, Bay }} \mathrm{F}_{\text {, Pisani }}$, Parkin D. GLOBOCAN 2002, Cancer incidence, mortalitity and prevalence worldwide. Lyon: IARCPress, 2004.

3. Hock LM, Lynch $J$, Balaji $\mathrm{KC}$. Increasing incidence of all stages of kidney cancer in the last 2 decades in the United States. an analysiss of surveillance, epidemiology and end results program data. Journal of urology $2002 ; 167: 57-60$.

4. Crocetti $\mathrm{E}$, Capocaccia $\mathrm{R}$, Casella $\mathrm{C}$, et al. Population-based incidence and mortality cancer trends (1986-1997) from the network of Italian cancer registries. Eur I Cancer Prev 2004:13:287-95.

5. Mathew A, Devesa $\mathrm{SS}$, Fraumeni $\mathrm{JF}^{*}, \mathrm{~J}_{\mathrm{r}, \mathrm{p}}$, Chow WH. Global increases in kidney cancer incidence, 1973-1992. European journal of cancer prevention 2002;1 1:171-8.

6. Chow WH, Devesa SS, Warren $\mathrm{JL}$, Fraumeni JF, Jr. Rising incidence of renal cell cancer in the United States. Jama 1999:281:1628-31.

7. Trends of cancer in the Netherlands 1989-1998. Utrecht: Vereniging van Intergrale Kanketcentra, 2002.

8. Sant $M$, Capocaccia $R$, Coleman MP, et al. Cancer survival increases in Europe, but international differences remain wide. Eur J Cancer 2001;37:1659-67.

9. Coleman MP, Gatta $G$, Verdecchia A, et al. EUROCARE-3 summary: cancer survival in Europe at the end of the 20th century. Ann Oncol 2003;14 Suppl 5:v128-49.

10. Kovacs $G$, Akhtar $M$, Beckwith BJ, et al. The Heidelberg classification of renal cell tumours [editorial]. J Pathol 1997;183:131-3.

11. Kaelin WG, Ir. The von hippel-lindau tumor suppressor gene and kidney cancer. Clin Cancer Res 2004; 10:6290S-5S.

12. Zbar B, Brauch $\mathrm{H}$, Talmadge $\mathrm{C}$, Linehan M. Loss of alleles of loci on the short arm of chromosome 3 in renal cell carcinoma. Nature 1987;327:721-4.

13. Decker HJ, Weidt EJ, Brieger J. The von Hippel-Lindau tumor suppressor gene. A rare and intriguing disease opening new insight into basic mechanisms of carcinogenesis. Cancer Genet Cytogenet 1997;93:74-83.

14. Richards FM. Molecular pathology of von Hippel-Lindau disease and the VHL tumour suppressor gene. Expert Rev Mol Med 2001;2001:1-27.

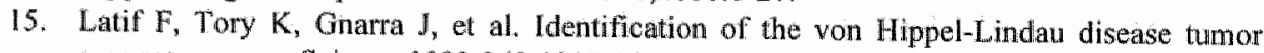
suppressor gene. Science 1993;260:1317-20.

16. Herman JG, Latif F, Weng $Y$, et al. Silencing of the VHL twmor-suppressor gene by DNA methylation in renal carcinoma. Proc Nat1 Acad Sci U S A 1994;91:9700-4.

17. Hamano K, Esumi M, Igarashi $H$, et al. Biallelic inactivation of the von Hippel-Lindau turnor suppressor gene in sporadic renal cell carcinoma. Journal of urology 2002;167:713-7.

18. Brauch $\mathrm{H}$, weirich $\mathrm{G}$, Brieger $J$, et al. VHL alterations in human clear cell renal cell carcinoma: association with advanced tumor stage and a noval hot spot mutation. Cancer Res 2000;60:1942-8.

19. Kondo $\mathrm{K}$, Ya $\mathrm{M}$, Yoshida $\mathrm{M}$, et al. Comprehensive mutational analysis of the VHL gene in sporadic renal cell carcinoma: relationship to clinicopathological parameters. Gene Chromosome Canc 2002;34:58-68.

20. Sufan RI, Jewett MA, Ohh M. The role of von Hippel-Lindau tumor suppressor protein and hypoxia in renal clear cell carcinoma. Am J Physiol Renal Physiol 2004;287:F1-6.

21. Maynard MA, Ohh M. Von Hippel-Lindau tumor suppressor protein and hypoxia-inducible factor in kidney cancer. Am J Nephrol 2004;24:1-13. 
22. Pause A, Lee $\mathrm{S}$, Lonergan KM, Klausner RD. The won Hippel-Lindau tumor suppressor gene is required for cell cycle exit upon serum withdrawal. Proc Natl Acad Sci U S A $1998 ; 95: 993-8$.

23. McLaughlin $J K$, Lipworth $L$. Epidemiologic aspects of renal cell cancer. Semin Oncol $2000 ; 27: 1.15-23$.

24. Lindblad P. Epidemiology of renal cell carcinoma. Scand J Surg 2004;93:88-96.

25. Dhote R, Pellicer Coeuret M, Thiounn $N$, Debre B, Vidal Trecan G. Risk factors for adult renal cell carcinoma: a systematic review and implications for prevention. BJU international 2000;86:20-7.

26. Mellemgaard A. Human renal-cell carcinoma-epidemiological and mechanistic aspects. LARC scientific publications 1999:69-80.

27. Wolk $A$, Lindblad $P$, Adami $\mathrm{HO}$. Nutrition and renal cell cancer. Cancer Causes Control 1996;7:5-18.

28. Tunt DD, van der Hel OL, McMillan GP, Boffetta $P$, Brennan P. Renal cell carcinoma in relation to cigarette smoking: Meta-analysis of 24 studies. Int I Cancer 2004;1 14:101-8.

29. Phillips DH. Smoking-related DNA and protein adducts in human tissues. Carcinogenesis 2002;23:1979-2004.

30. Hecht SS. Human urinary carcinogen metabolites: biomarkers for investigating tobacco and cancer. Carcinogenesis 2002;23:907-22.

31. Bergstrom A, Hsieh CC, Lindblad P, Lu CM, Cook NR, Wolk A. Obesity and renal cell cancer--a quantitative review. Br J Cancer 2001;85:984-90.

32. Bergstrom A, Pisani P, Tenet V, Wolk A, Adami HO. Overweight as an avoidable cause of cancer in Europe. Int J Cancer 2001;91:421-30.

33. Grossman E, Messerli FH, Boyko V, Goldbourt U. Is there an association between hypertension and cancer mortality? Am J Med 2002;112:479-86.

34. Grossman E, Messerli FH, Goldbourt U. Does diuretic therapy increase the risk of renal cell carcinoma? [editorial] [see comments]. Am J Cardiol 1999;83:1090-3.

35. Grove JS, Nomura A, Severson RK, Stemmermann GN. The association of blood pressure with cancer incidence in a prospective study. American joumal of epidemiology 1991;134:942-7.

36. Chow WH, Gridley G, Fraumeni JF, Jr., Jarvholm B. Obesity, hypertension, and the risk of kidney cancer in men. N Engl J Med 2000;343:1305-11.

37. Coughin SS, Neaton JD, Randall B, Sengupta A. Predictors of mortallity from kidney cancer in 332,547 men screened for the Multiple Risk Factor Intervention Trial. Cancen $1997 ; 79: 2171-7$.

38. Rosengren $\mathrm{A}$, Himmelmann $\mathrm{A}$, Wilhelmsen $\mathrm{L}$, Branehog $\mathrm{I}_{3}$ Wedel $\boldsymbol{H}$. Hypertension and long-tern cancer incidence and morlality among Swedish men. J Hypertens 1998;16: $933-40$.

39. Mellemgard A, Moller H, Olsen JH. Diuretics may increase risk of renal cell carcinoma. Cancer Causes Control 1992;3:309-12.

40. Prineas RJ, Folsom AR, Zhang ZM, Sellers TA, Potter J. Nutrition and other risk factors for renal cell carcinoma in postmenopausal women. Epidemiology 1997;8:31-6.

41. Heath CW, Jr., Lally CA, Calle EE, McLaughlin JK, Thun MJ. Hypertension, diuretics, and antihypertensive medications as possible risk factors for renal cell cancer. Am J Epidemiol $1997 ; 145: 607-13$.

42. McLaughlin JK, Chow WH, Mandel JS, et al. International renal-cell cancer study. VIII. Role of diuretics, other anti-hypertensive medications and hypertension. Int J Cancer $1995 ; 63: 216-21$. 
43. Shapiro: JA, Williams MA, Weiss NS, Stergachis A, LaCroix AZ, Barlow WE. Hypertension, antibypertensive medication use, and risk of renal cell carcinoma. Am J Epidemiol 1999;149:521-30.

44. Brauch $H_{\text {, }}$ Weirich $G$, Homauer MA, Storkel $\mathrm{S}$, WohI $\mathrm{T}$, Bruming $\mathrm{T}$. Trichloroethylene exposure and speciffe somatic mutations in patients with renal cell carcinoma. $J \mathrm{Natl}$ Cancer Inst 1999,91:854-61.

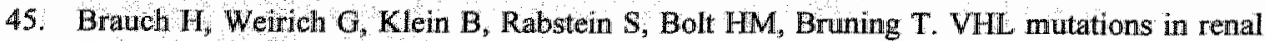
cell cancer does accupational exposure to trichlloroethylene make a difference? Toxicol Lett 2004;151:301-10.

46. Hemmink $\mathrm{K}$, liang $\mathrm{Y}$, Ma X, Yang K, Egevad L, Lindblad P. Molecular epidemiology of VHL gene mutationis in renal cell carcinoma patients: relation to dietary and other factors. Carcinogenesis 2002;23:809-15.

47. Van den Brandt PA, Goldbohm RA, Van 't Veer P, Volovics A, Hermus RJ, Sturmans F. A large-scale prospective cohort study on diet and cancer in The Netherlands. I Clin Epidemio $1990 ; 43: 285-95$.

48. Goldbohm RA, Van den Brandt PA, Dorant E. Estimation of the coverage of Dutch municipalities by cancer registries and PALGA based on hospital discharge data. Tijdschr Soc Gezondheidsz $\$ 994 ; 72: 80-4$ 


\section{2}

Relation of height, body mass, energy intake, physical activity to risk of renal cell carcinoma: results from the Netherlands cohort study

Boukje A.C. van Dijk Leo J. Schouten

Lambertus A.L.M. Kiemeney R. Alexandra Goldbohm

Piet A. van den Brandt 


\begin{abstract}
Data from the Metherlands Colont Study on diet and cancer (NLCS) were used to investigate the association between anthroponnery, energy intake and physical activity and risk of renal cell carcinoma (RCC). The NLCS consists of 120,852 men and women aged 55-69 years who completed a self-administered questionnaire at baseline (1986). A case-cohort approuch was used. Atter 9.3 years of follow-up, 275 microscopically confmed incident cases were available for analysis. Incidence rate ratios for RCC were estimated using Cox proportional hazard models. Height was associated with RCC risk only in women (per 5-cm increment, ate tatio (RR): $1.23 ; 95 \%$ confidence interval (CD) 1.03-1.46). Body mass index (weight (kg)/height $\left.(\mathrm{m})^{2}\right)$ was alssociated with increased risk of RCC (per $1-\mathrm{kg} / \mathrm{m}^{2}$ increment, RR: $1.07 ; 95 \% \mathrm{CI}$ : $1.02-1.12$ ) for men and women, as was gain in body mass index from age 20 years to baseline (per $1-\mathrm{kg} / \mathrm{m}^{2}$ increment. RR: 1.06; $95 \% \mathrm{Cl}: 1.01-1.10$ ). Energy intake was not related to RCC risk, while a possible protective effect was observed for physical activity in men. These resuits suggest that body mass index and gain in body mass index since age 20 are associated with increased risk of RCC.
\end{abstract}




\section{Introduction}

Body mass index (BMI), the ratio of weight $(\mathrm{kg})$ to the square of height $\left(\mathrm{m}^{2}\right)$, is believed to be an important risk factor for Renal Cell Carcinoma (RCC). In a quantitative review, a summary relative risk per $1-\mathrm{kg} / \mathrm{m}^{2}$ increase in BMT of $1.07(95 \%$ confidence interval (CI): 1.05-1.09) was found for men and women". The attributable proportion of RCC for excess body weight is estimated to be $25 \%$ for both men and women in the European Union ${ }^{2}$. Most studies have reported an association between BMI and RCC for both sexes ${ }^{3-10}$, but some studies have reported associations confined to men ${ }^{1-13}$ or women ${ }^{14,15}$. Inconsistent reports exist on the association between height and $\mathrm{RCC}$ risk $^{10,13,16}$. High body weight is associated with increased risk of RCC, particularly among women ${ }^{17,18}$ and weight changes should be investigated further ${ }^{18}$. Reports on energy intake ${ }^{15,19}$ and physicall activity ${ }^{16,20,211}$ have been inconsistent.

BMT is a measure of body mass relative to height. In general, there is good correlation between BMI and percentage of body fat. Obesity or excess body fat is caused by excess energy intake relative to energy expenditure, which consists of resting metabolic rate, the thermic effect of food, posture and spontaneous activity, and voluntary physical activity ${ }^{22}$.

Two different biological mechanisms have been proposed to explain the observed relation between BMI and renal cancer risk. Physical activity and energy intake may also fit these mechanisms. Yu and Rohan ${ }^{23}$ proposed that the insulin-like growth factor I (IGF-I) system may be the mechanistic link between obesity and the development of RCC. IGF-I has been shown to stimulate cell proliferation and inhibit apoptosis ${ }^{23}$, both of which favor tumor growth. In humans, it has been shown that obese persons have increased serum levels of free IGF-I ${ }^{22}$. Overnutrition has been reported to increase levels of $\mathrm{IGF}_{-} \mathrm{I}^{23}$, while no conclusions can be drawn regarding the effect of physical activity on IGF-I levels ${ }^{22,24-28}$.

Secondly, the process of lipid peroxidation may be involved ${ }^{29}$. Byproducts of lipid peroxidation have been shown to react with renal cell DNA to form adducts, which may lead to mutations. Obese subjects are known to exhibit increased lipid peroxidation, while exercise programs resulted in reduced lipid peroxidation. Furthermore, it has been proposed that lipid peroxidation may also explain the roles of other risk factors, such as smoking, and protective factors, such as intake of foods high in antioxidants, in the development of $\mathrm{RCC}^{29}$.

Hence, it would be logical to investigate BMI, energy intake and physical activity simultaneously. To our knowledge, only one study investigated the roles of BMI, physical activity and energy intake together ${ }^{21}$, but the emphasis of that study was on physical activity ${ }^{21}$. In this study, a prospective cohort study with a relatively large number of cases, we estimated the effects of height, weight, BMI, BMI at age 20 years, BMI change since age 20 years, energy intake, and physical activity on risk of RCC. We also investigated the effects of BMI, energy intake and physical activity simultaneously. 


\section{Materials and methods}

\section{The Netherlands Cohort Study on diet and cancer}

The study design, including data-collection strategies, has been described in detail previously ${ }^{30}$. Briefly, this population-based prospective cohort study on diet and cancer started in the Netherlands in September 1986. The cohort includes 58,279 men and 62,573 women who were aged 55-69 years at baseline. The study was designed as a case-cohort study, using all cases and a random sample of 5,000 persons from the cohort (subcohort), who have been followed for estimation of the accumulated personyears in the entire cohort ${ }^{31}$.

\section{Follow-up}

Incident cancer cases occurring in the total cohort were identified through record linkage to the Netherlands cancer registries and PALGA (the national automated pathology archive $)^{32}$. The completeness of cancer follow-up was estimated to be more than $96 \% \%^{33}$. This gave us 275 incident cases (179 men and 96 women) with microscopically confirmed adenocarcinoma of the renal parenchyma and no prevalent cancer at baseline.

Follow-up of the subcohort was almost complete; out of the 5,000 subcohort members $(2,411$ men and 2,589 women), only two men were lost to follow-up after 9.3 years (September 1986 - December 1995). Subcohort members with prevalent cancer (other than skin cancer) at baseline were excluded ( 76 men and 145 women) from the analyses, leaving 4,779 subcohort members (2,335 men and 2,444 women).

\section{Questionnaire}

At baseline, all cohort members completed a self-administered questionnaire, which has been described elsewhere ${ }^{34}$. Questions were asked about current height, current weight, weight at age 20 years, family history of cancer, physical activity, job history and usual consumption of food and beverages during the year preceding the start of the study.

BMI was calculated by dividing weight $(\mathrm{kg})$ by height squared $\left(\mathrm{m}^{2}\right)$. Rate ratios are presented per $1-\mathrm{kg} / \mathrm{m}^{2}$ increment for BMI at baseline, BMI at age 20 years, and BMI gain between age 20 years and baseline. In addition, BMI at baseline was categorized into the following categories: $\mathrm{BMI}<23,23 \leq \mathrm{BMI}<25,25 \leq \mathrm{BMI}<27,27 \leq \mathrm{BMI}<30$, and $B M \geq 30$. Because of missing values, analyses for BMI were based on 264 incident cases and 4,592 subcohort members. For BMI at age 20 years, participants were categorized into four groups: $\mathrm{BMI}<20,20 \leq \mathrm{BMI}<21,21 \leq \mathrm{BMI}<23$, and $\mathrm{BMI} \geq 23$. Gain in BMI $\left(\mathrm{kg} / \mathrm{m}^{2}\right)$ was categorized as $<0,0-4,4-8$, or $\geq 8$. Analyses for BMI at age 20 and BMI gain since age 20 were based on 227 cases and 3,905 subcohort members, since not all participants provided information on their weight at age 20 . 
Energy-intake was calculated from the food frequency questionnaire ${ }^{34,35}$ using the computerized Dutch Food Composition table ${ }^{36}$. Fifteen cases and 338 subcohort members with incomplete or inconsistent dietary data were excluded from the analyses. Details are given elsewhere ${ }^{34}$. On the basis of the distribution in the subcohort, energyintake was divided into quintiles for men and women separately.

Physical activity was divided into occupational and nonoccupational activity. In this paper, we use the term "nonoccupational physical activity" to cover both recreational physical activity and the physical activity involved in getting to and from work (e.g., walking, cycling). For estimation of occupational activity, participants were asked to report job title(s) and job duration(s). Assessment of physical activity at work was based on the job held for the longest amount of time. Total energy expenditure was based on a rating system developed by Hettinger et al. ${ }^{37}$. Participants were classified into three energy expenditure groups: $<8 \mathrm{~kJ} /$ minute, $8-12 \mathrm{~kJ} /$ minute, and $\geq 12 \mathrm{~kJ} / \mathrm{min}$. Occupational physical activity was not calculated for women, since most women of this generation had not held a job or had worked for only a short period of time, mostly in the distant past. Baseline nonoccupational physical activity was calculated by adding up the number of minutes spent per day on cycling/walking to work, shopping, and walking the dog, and the number of hours spent per week on gardening/odd jobs, recreational cycling/walking and sports/exercise, as reported ${ }^{38}$.

\section{Statistical analysis}

On the basis of the literature, age (continuous variable), sex and cigarette smoking (current smoking (yes/no), number of years of smoking, and number of cigarettes smoked per day) were considered as confounders. We did not adjust for family history of RCC (present or not present in a first-degree relative), since only 49 participants ( 4 cases and 45 subcohort members) reported having a first-degree relative with RCC. Incidence rate ratios for height and weight were obtained from models in which both variables were always entered simultaneously. Results for BMI are additionally adjusted for energy intake and physical activity. We also investigated whether BMI at age 20 (as a proxy for young adulthood) or BMI gain between age 20 and baseline were independent predictors of RCC risk. In all BMI gain regression models, we adjusted for BMI at age 20. Furthermore, we calculated RCC rate ratios for energy intake and physical activity variables (entered into a model together) with adjustment for age only and adjustment for age, smoking and BMI. Results are shown for men and women together to enhance the precision of our statistical analyses, unless the $p$ value for the interaction term between sex and the variable of interest was less than or equal to 0.05 .

Rate ratios and 95 percent confidence intervals for $\mathrm{RCC}$ were estimated in Cox proportional hazards models using 2001 STATA statistical software (release 7; Stata Corporation, College Station, Texas), after testing the proportional hazards assumption using scaled Schoenfeld residues ${ }^{39}$. Standard errors were estimated using the robust Huber-White sandwich estimator to account for additional variance introduced by 
sampling from the cohort ${ }^{40}$. To obtain $p$ walues for dose-response trends, we fitted ordinal exposure variables as continuous terms. Two sided $p$ values are reported throughout this paper.

\section{Results}

Mean weight, height and BMI at baseline were higher for cases than for subcohort members (Table 2.1). Cases more often smoked than subcohort members: $44.7 \%$ of male cases and $24.2 \%$ of female cases smoked at baseline as compared with $36.8 \%$ of male subcohort members and $21.0 \%$ of female subcohort members (Table 2.1).

Results for height, weight, and non-occupational physical activity are shown stratified by sex. The interaction term for sex $X$ height was statistically significant $(p=0.02)$. Even though the interaction terms for weight and non-occupational physical activity were not statistically significant $(p=0.20$ and $p=0.21$, respectively), we decided to show results stratified by sex, since category limits for weight differed for men and women and estimates for nonoccupational physical activity pointed in a different directions for men and women.

Height was not associated with RCC risk in men (Table 2.2). In women, however, an increased risk of 1.23 per $5 \mathrm{~mm}$ increment $(95 \% \mathrm{CI}: 1.03-1.46$ ) was observed (Table 2.2). Weight increased RCC risk approximately $10 \%$ per $5 \mathrm{~kg}$ for men and women (Table 2.2), while further adjustment for smoking did not materially change the risk estimates.

A high BMI was associated with increased risk of $\mathrm{RCC}$ (per $1-\mathrm{kg} / \mathrm{m}^{2}$, rate ratio (RR): $1.05 ; 95 \% \mathrm{CI}: 1.01-1.10$ ), though the trend was not linear (Table 2.3). Additional adjustment for smoking did not alter the estimates (data not shown). After further adjustment for energy intake and physical activity, the increased risk of BMI remained (RR: $1.07 ; 95 \%$ CI: $1.02-1.12$ ) (Table 2.3).

BMI at age 20 years was not related to RCC (Table 2.3). However, gaining body mass in adult life was associated with an increase in risk of RCC. A BMI gain of $1 \mathrm{~kg} / \mathrm{m}^{2}$ was associeted with increased RCC risk (RR: $1.06 ; 95 \% \mathrm{Cl}: 1.01-1.10$ ) (Table 2.3). 
Table 2.1 Distribution of data on anthroponetrical wariables, energy-intake, physical activity and potential confounders among patients with renal cell carcinoma and subeohort members at baseline, Netherlands Cohort Study on Diet and Cancer, 1986-1995.

\begin{tabular}{|c|c|c|c|c|c|}
\hline & \multirow[b]{2}{*}{ Category } & \multicolumn{2}{|l|}{ Cases } & \multicolumn{2}{|l|}{ Subcohort } \\
\hline & & Mean $\left(\mathrm{SD}^{6}\right)$ & $\%$ & Mean $\left(\mathrm{SD}^{\mathrm{b}}\right)$ & $\%$ \\
\hline \multicolumn{6}{|l|}{ Exposwre variables } \\
\hline \multicolumn{6}{|l|}{ Height $(\mathrm{cm})$ at baseline } \\
\hline Men & & $176.6(7.0)$ & & $176.4(6.7)$ & \\
\hline Women & & $166.9(5.8)$ & & $165.1(6.2)$ & \\
\hline \multicolumn{6}{|l|}{ Weight (kg) at baseline } \\
\hline Men & & $79.3(9.8)$ & & $779(9.5)$ & \\
\hline Women & & $71.7(10.8)$ & & $68.5(10.3)$ & \\
\hline Body mass index at baseline & & $25.5(3.1)$ & & $25.1(3.1)$ & \\
\hline Body mass index at age 20 years & & $21.7(2.6)$ & & $21.5(2.6)$ & \\
\hline $\begin{array}{l}\text { Change in body mass index (baseline } \\
\text { minus age } 20 \text { ) }\end{array}$ & & $3.9(3.3)$ & & $3.5(3.4)$ & \\
\hline \multicolumn{6}{|l|}{ Energy intake (kcal/day) } \\
\hline Men & & $2140(500)$ & & $2166(511)$ & \\
\hline Women & & $1652(375)$ & & $1686(397)$ & \\
\hline Occupational physical activity & $<8$ & & $59.10 \%$ & & $57.6 \%$ \\
\hline \multirow[t]{2}{*}{ (men only) (kJ/minute) } & $8-12$ & & $26.5 \%$ & & $26.5 \%$ \\
\hline & $>12$ & & $14.4 \%$ & & $16.0 \%$ \\
\hline \multicolumn{6}{|l|}{$\begin{array}{l}\text { Nonoccupational physical activity } \\
\text { (minutes/day) }\end{array}$} \\
\hline \multicolumn{6}{|l|}{ Men } \\
\hline$<30$ & & & $22.8 \%$ & & $18.4 \%$ \\
\hline $30-60$ & & & $24.0 \%$ & & $30.9 \%$ \\
\hline $60-90$ & & & $17.0 \%$ & & $18.8 \%$ \\
\hline$>90$ & & & $36.3 \%$ & & $31,9 \%$ \\
\hline \multicolumn{6}{|l|}{ Women } \\
\hline$<30$ & & & $26.4 \%$ & & $24.9 \%$ \\
\hline $30-60$ & & & $31.0 \%$ & & $31.1 \%$ \\
\hline $60-90$ & & & $24.1 \%$ & & $22.5 \%$ \\
\hline$>90$ & & & $18.4 \%$ & & $21.4 \%$ \\
\hline \multicolumn{6}{|l|}{ Confounding factors } \\
\hline Age (years) & & $62.1(3.9)$ & & $61.4(4.2)$ & \\
\hline \multicolumn{6}{|l|}{ Current cigarette smoker } \\
\hline Men & & & $44.7 \%$ & & $36.8 \%$ \\
\hline Women & & & $24.2 \%$ & & $21.0 \%$ \\
\hline \multicolumn{6}{|l|}{ No. of cigarettes smoked per day } \\
\hline Men & & $\| 7.6(12.7)$ & & $14.7(11.4)$ & \\
\hline Women & & $4.5(7.6)$ & & $4.6(7.7)$ & \\
\hline \multicolumn{6}{|l|}{ No. of years of smoking } \\
\hline Men & & $33.8(14.0)$ & & $29.4(15.9)$ & \\
\hline Women & & $11.8(16.0)$ & & $11.3(15.9)$ & \\
\hline
\end{tabular}

Analyses were based on 275 incident cases (179 men and 96 women) and 4,779 subcohort members $(2,335$ men and 2,444 women), though totals vary because of missing walues. Data pertain to both sexes unless otherwise specified; "SD, standard deviation; "Weight (kg)/height(m) 
Table 2.2 Rate ratios for renal cell carcinoma according to height and weight, Netherlands Cohort Study on Diet and Cancer $1986-1995^{\text {a }}$

\begin{tabular}{|c|c|c|c|c|c|c|c|}
\hline Variable & $\begin{array}{l}\text { Categorical } \\
\text { mean }\end{array}$ & $\begin{array}{l}\text { No. of } \\
\text { casses }\end{array}$ & $\begin{array}{l}\text { No. of person- } \\
\text { years in subcohort }\end{array}$ & $\mathrm{RR}^{\mathrm{b}, \mathrm{c}}$ & $95 \% \mathrm{Cl}^{b}$ & $\mathbf{R R}^{d}$ & $95 \% \mathrm{CI}$ \\
\hline
\end{tabular}

Height (eri) at baseline

Men

$$
\begin{aligned}
& <170^{\circ} \\
& 170-<175 \\
& 175-<180 \\
& 180-<185 \\
& >=185
\end{aligned}
$$$$
p \text { trend }
$$

Continuous variable

(per $5-\mathrm{cm}$ increment)

Women

$$
\begin{aligned}
& <160^{\circ} \\
& 160-<165 \\
& 165-<170 \\
& 170-<175 \\
& >=175
\end{aligned}
$$

$p$ trend

Continuous variable (per $5-\mathrm{cm}$ increment) Weight ( $\mathrm{kg}$ ) at baseline Men

$$
\begin{aligned}
& <75^{\circ} \\
& 75-<80 \\
& 80-<85 \\
& 85-<90 \\
& >=90
\end{aligned}
$$

$p$ trend

Continuous variable

(per $5+\mathrm{kg}$ increment)

Women

$$
\begin{aligned}
& <65^{\circ} \\
& 65-<70 \\
& 70-<75 \\
& 75-<80 \\
& >=80
\end{aligned}
$$

$p$ trend

Continuous variable (per 5-kg increment)

$\begin{array}{lllllll}166.0 & 25 & 2,630 & 1 & & 1 & \\ 171.9 & 38 & 4,802 & 0.81 & 0.47-1.37 & 0.72 & 0.42-1.25 \\ 176.8 & 57 & 5,689 & 1.00 & 0.59-1.70 & 0.87 & 0.50-1.54 \\ 181.7 & 31 & 3,892 & 0.72 & 0.40-1.29 & 0.70 & 0.38-1.28 \\ 188.0 & 22 & 2,310 & 0.75 & 0.39-1.43 & 0.71 & 0.36-1.39 \\ & & & 0.37 & & 0.38 & \\ & 173 & 19,322 & 0.96 & 0.84-1.11 & 0.97 & 0.84-1.13\end{array}$

$\begin{array}{rrrrrrr}155.7 & 10 & 3,582 & 1 & & 1 & \\ 161.9 & 20 & 5,326 & 1.26 & 0.59-2.70 & 1.20 & 0.53-2.74 \\ 166.8 & 31 & 6,962 & 1.41 & 0.69-2.90 & 1.55 & 0.73-3.27 \\ 171.5 & 22 & 3,595 & 1.79 & 0.84-3.79 & 1.95 & 0.89-4.30 \\ 176.9 & 8 & 1,521 & 1.56 & 0.68-3.55 & 1.64 & 0.67-3.99 \\ & & & 0.13 & & 0.07 & \\ & 91 & 20,986 & 1.17 & 0.99-1.39 & 1.23 & 1.03-1.46\end{array}$

$\begin{array}{lllllll}68.5 & 55 & 7,055 & 1 & & 1 & \\ 76.4 & 35 & 3,820 & 1.17 & 0.74-1.84 & 1.17 & 0.72-1.89 \\ 81.4 & 32 & 4,000 & 1.10 & 0.68-1.77 & 1.06 & 0.64-1.76 \\ 86.2 & 21 & 2,130 & 1.35 & 0.78-2.32 & 1.29 & 0.73-2.29 \\ 94.9 & 30 & 2,317 & 1.76 & 1.04-2.96 & 1.73 & 0.99-3.00 \\ & & & 0.05 & & 0.07 & \\ & 173 & 19,322 & 1.10 & 1.00-1.21 & 1.09 & 0.98-1.20\end{array}$

$\begin{array}{lllllll}58.5 & 22 & 7,498 & 1 & & 1 & \\ 66.6 & 19 & 4,351 & 1.29 & 0.69-2.40 & 1.18 & 0.62-2.26 \\ 71.4 & 14 & 3,748 & 1.08 & 0.55-2.12 & 1.10 & 0.56-2.17 \\ 76.3 & 1.6 & 2,328 & 2.04 & 1.07-3.91 & 2.09 & 1.08-4.02 \\ 86.1 & 20 & 3,060 & 1.91 & 1.06-3.47 & 1.54 & 0.82-2.92 \\ & & & 0.01 & & 0.05 & \\ & 91 & 20,986 & 1.13 & 1.02-1.24 & 1.11 & 1.01-1.23\end{array}$

\footnotetext{
"Height and weight were always entered into the model simultaneously. Numbers of cases and person-years in the subcohort were lower in the multivariable analyses because of missing values; ${ }^{2} \mathrm{RR}$, rate ratio; $\mathrm{Cl}$,

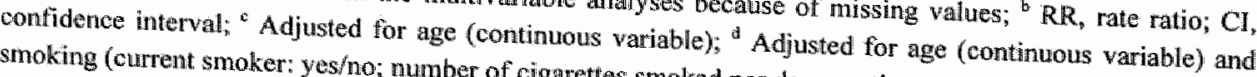
smoking (current smoker: yes/no; number of cigarettes smoked per day: continuous variable; number of years
of smoking: continuous variable); ${ }^{-}$Reference group
} 
Table 2.3. Rate ratios for renal cell carcinoma according to BMI, "BMI at age 20 years, and change in BMI between age 20 years and baseline, Netherlands Cohort Study on Diet and Cancer, 1986-1995.

\begin{tabular}{|c|c|c|c|c|c|c|c|}
\hline Variable & $\begin{array}{c}\text { Categarical } \\
\text { mean }\end{array}$ & $\begin{array}{l}\text { No. of } \\
\text { cases }\end{array}$ & $\begin{array}{c}\text { No of person- } \\
\text { years in } \\
\text { subcohort }\end{array}$ & $\mathrm{RR}^{\mathrm{a}} \mathrm{c}$ & $95 \% \mathrm{Cl}^{\mathrm{s}}$ & $\mathbb{R} \mathbb{R}$ & $95 \% \mathrm{Cl}$ \\
\hline \multicolumn{8}{|l|}{ BMT at baseline $\mathrm{e}^{\mathrm{e}}$} \\
\hline$<23$ & 21.4 & 49 & 9,596 & 0.81 & $0.56-1.17$ & 0.77 & $0.50-1.19$ \\
\hline $23-<25^{f}$ & 24.0 & 83 & 12,032 & 1 & & 1 & \\
\hline $25-<27$ & 25.9 & 54 & 9,460 & 0.81 & $0.57-1.16$ & 0.92 & $0.61-1.38$ \\
\hline $27-<30$ & 28.2 & 62 & 6,503 & 1.40 & $0.99-1.97$ & 1.46 & $0.97-2.21$ \\
\hline$>=30$ & 32.3 & 16 & 2,717 & 1.03 & $0.59-1.80$ & 1.04 & $0.54-1.99$ \\
\hline$p$ trend & & & & 0.05 & & 0.04 & \\
\hline Continuous variab̆le (per $\mathrm{kg} / \mathrm{m}^{2}$ ) & & 264 & 40,308 & 1.05 & $1.01 \cdot 1.10$ & 1.07 & $1.02-1.12$ \\
\hline \multicolumn{8}{|l|}{ BMI at age 20 years: } \\
\hline$<20^{\mathbb{f}}$ & 18.4 & 58 & 8,876 & 1 & & $\mathbb{1}$ & \\
\hline $20-<21$ & 20.5 & 28 & 5,559 & 0.67 & $0.42-1.08$ & 0.76 & $0.47-1.23$ \\
\hline $21-<23$ & 22.0 & 70 & 10,964 & 0.88 & $0.61-1.26$ & 0.96 & $0.66-1.41$ \\
\hline$>=23$ & 24.7 & 72 & 9,062 & 1.11 & $0.78-1.59$ & 1.18 & $0.80-1.72$ \\
\hline$p$ trend & & & & 0.41 & & 0.29 & \\
\hline Continuous variable (per $\mathrm{kg} / \mathrm{m}^{2}$ ) & & 228 & $34,46 \|$ & 1.02 & $0.97-1.08$ & 1.03 & $0.98-1.08$ \\
\hline \multicolumn{8}{|l|}{$\begin{array}{l}\text { Change in BMI since age } 20 \\
\text { years }^{\text {, }} \text {, }\end{array}$} \\
\hline$<0$ & -2.0 & 14 & 3,735 & 0.51 & $0.29-0.90$ & 0.50 & $0.27-0.90$ \\
\hline $0-<4^{\mathbb{P}}$ & 2.2 & 115 & 16,445 & 1 & & 1 & \\
\hline $4-<8$ & 5.7 & 74 & 11,170 & 1.04 & $0.76-1.43$ & 1.02 & $0.74-1.42$ \\
\hline$>=8$ & 10.2 & 24 & 3,002 & 1.53 & $0.96-2.46$ & 1.34 & $0.79-2.19$ \\
\hline$p$ trend & & & & 0.01 & & 0.04 & \\
\hline Continuous variable (per $\mathrm{kg} / \mathrm{m}^{2}$ ) & & 227 & 34,352 & 1.07 & $1.02-1.11$ & 1.06 & $1.01-1.10$ \\
\hline
\end{tabular}

${ }^{2} \mathrm{BMI}$, body mass index; $\mathbb{R R}$, rate ratio; $\mathrm{Cl}$, confidence interval; ${ }^{\text {b }}$ Numbers of cases and person-years in the subcohort were lower in the multivariable analyses because of missing values. All data pertain to both sexes:

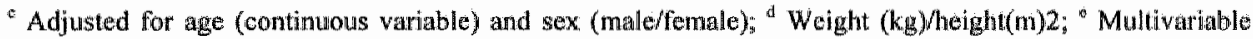
rate ratios were adjusted for age (contimuous variable), sex (male/female), smoking (current smoker: yes/no; number of cigarettes smoked per day: continuous wariable; number of years of smoking: continuous variable), energy intake (continuous variable), non-occupational physical activity $(<30,30-60,60-90$, or $>90$ min/day $)_{6}$ and, for men only, occupational physical activity $(<8,8-12$, or $>12 \mathrm{kj} / \mathrm{min})$; ${ }^{\circ}$ Reference group; Multivariable rate ratios were adjusted for age (continuous variable), sex (male/female), and smoking. (current smoker: yes/no; number of cigarettes smoked per day: continuous variable; number of years of smoking: continuous variable);

Energy intake was not related to risk of RCC. Estimates did not change after adjustment for smoking or after further adjustment for BMI and physical activity (data not shown). In addition, we tested the highest quintile against the first quintile for energy intake. We did not observe an increased risk for persons in the highest quintile, either in the model with age, sex and physical activity (RR: $0.80 ; 95 \% \mathrm{Cl}: 0.50-1.27$ ) or in the model additionally adjusted for smoking and BMI (RR: $0.83 ; 95 \% \mathrm{CI}: 0.51-$ $1.36)$. 
For men, estimates for occupational physical activity greater than or equal to $8 \mathrm{kj} /$ minute or nonoccupational physical activity greater than or equal to 30 minutes/day were all less than 1 (Table 2.4). Moreover, the risk for men was significantly decreased for nonoccupational physical activity of 30-60 minutes/day (RR: $0.52 ; 95 \%$ CI: $0.30-0.91$ ), but there was no significant trend ( $p=0.63$ ). Estimates for nonoccupational physical activity for women (Table 2.4) were mostly larger than one but never statistically significant.

Table 2.4 Rate ratios for renal cell carcinoma according to physical activity, Netherlands Cohort Study on Diet and Cancer, 1986-1995.

\begin{tabular}{|c|c|c|c|c|c|c|}
\hline Vuriable & $\begin{array}{l}\text { No. of } \\
\text { cases }\end{array}$ & $\begin{array}{l}\text { No. of person- } \\
\text { years in } \\
\text { subcohort }\end{array}$ & $\mathbb{R R}^{b, c}$ & $95 \% \mathrm{Cl}^{\mathrm{b}}$ & $\mathbb{R R}^{\mathbb{d}}$ & $95 \% \mathrm{Cl}$ \\
\hline \multicolumn{7}{|c|}{$\begin{array}{l}\text { Occupational physical activity } \\
\text { (men only) (kJ/minute) }\end{array}$} \\
\hline$<8^{*}$ & 76 & 8,617 & 1 & & $\mathbb{1}$ & \\
\hline $8-12$ & 35 & 3,905 & 0.98 & $0.64-1.49$ & 0.86 & $0.54-1.39$ \\
\hline$>12$ & 19 & 2,312 & 0.86 & $0.50-1.46$ & 0.82 & $0.46-1.47$ \\
\hline$p$ trend & & & 0.60 & & 0.44 & \\
\hline \multirow{2}{*}{\multicolumn{7}{|c|}{$\begin{array}{l}\text { Nonoccupational physical } \\
\text { activity (minutes/day) } \\
\text { Men }\end{array}$}} \\
\hline & & & & & & \\
\hline$<30^{\mathrm{e}}$ & 34 & 2,580 & 1 & & 1 & \\
\hline $30-60$ & 30 & 4,861 & 0.46 & $0.28-0.77$ & 0.52 & $0.30-0.91$ \\
\hline $60-90$ & 24 & 2,732 & 0.67 & $0.38-1.17$ & 0.63 & $0.34-1.16$ \\
\hline$>90$ & 42 & $4,66 \|$ & 0.66 & $0.4 \pi-1.07$ & 0.74 & $0.44-1.23$ \\
\hline$p$ trend & & & 0.47 & & 0.63 & \\
\hline \multicolumn{7}{|l|}{ Women } \\
\hline$<30^{\circ}$ & 23 & 4,937 & 1 & & 1 & \\
\hline $30-60$ & 27 & 6,234 & 0.95 & $0.54-1.68$ & 1.13 & $0.59-2.15$ \\
\hline 60.90 & 21 & 4,444 & 1.07 & $0.59-1.94$ & $1.43 i$ & $0.73-2.79$ \\
\hline$>90$ & 15 & 4,279 & 0.85 & $0.44-1.63$ & 1.13 & $0.56-2.29$ \\
\hline$p$ trend & & & 0.74 & & 0.55 & \\
\hline
\end{tabular}

"Numbers of cases and person-years in the subcohort were lower in multivariable analyses because of missing values. Occupational and nonoccupational physical activity were simultaneously entered into the

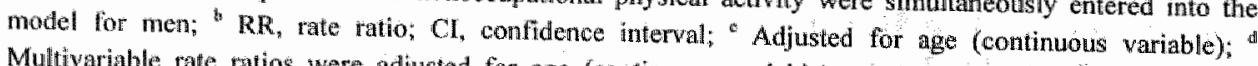
Multivariable rate ratios were adjusted for age (continuous varable), snoking (current smoker: yes/no; number of cigarettes smoked per day: continuous variable; number of years of smoking: continuous variable), energy intake (continuous variable), and body mass index (weight $(\mathrm{kg}) /$ height $\left.(\mathrm{m})^{2}\right)$; "Reference 


\section{Discussion}

Our results suggest that a high $\mathrm{BMI}$ is an independent risk factor for $\mathrm{RCC}$ and that this relation is not influenced by energy intake and/or physical activity. Furthermore, energy intake does not seem to be an independent risk factor for $\mathrm{RCC}$, while the role of physical activity remains unclear. BMI at age 20 years was not related to RCC risk, while BMI gain between young adulthood and baseline was associated with increased $\mathrm{RCC}$ risk. For women, height was associated with an increased risk of RCC.

Since $\mathrm{RCC}$ is relatively rare, most studies that have evaluated the relation between anthropometric measures and RCC risk have been case-control studies. Only four cohort studies have reported on the relation between anthropometric factors and RCC risk $^{10,13.15,41}$. The prospective cohort setting makes selection bias in our study unlikely, while case-control studies, especially hospital-based case-control studies, may suffer from selection and information bias. In the current study, the estimated rate ratio for the association between BMI and RCC was 1.07, based on 264 incident cases. This is in line with the findings of a meta-analysis on 14 studies $^{1}$ and the results of other cohort studies reporting on BMI and RCC risk ${ }^{10,13,15,41}$. Only one hospital-based case-control study reported no association between BMI and RCC risk ${ }^{42}$. Height and weight were self-reported in our study, as in most other studies, which means misclassification might be present. Systematic underestimation of weight and overestimation of height have been reported ${ }^{43,44}$. More specifically, the higher the measured BMI, the greater the underestimation of weight and the overestimation of height for men and women ${ }^{44}$. This tendency could have lead to underestimation of the effect of BMI on RCC risk in our study.

An increased risk of RCC with increasing BMI has been reported consistently. This observation may fit both suggested biological mechanisms, since it has been reported that obese persons have higher levels of free IGF- $\mathrm{I}^{22}$ and exhibit increased lipid peroxidation ${ }^{29}$. Both have been linked to tumor development. In view of the strong relation between $\mathrm{BMI}$ and $\mathrm{RCC}$, it is remarkable that no convincing mechanism has yet been proposed for this relation. Further research is needed.

In this study, we found $\mathrm{RCC}$ risk to increase with height (contradictory to most other studies on height and RCC) in women. An increased cancer risk with height has been observed before for women in the Netherlands Cohort Study on Diet and Cancer for breast cancer ${ }^{45}$ and ovarian cancer ${ }^{46}$. However, for men, an increased risk with height was not observed in the current study or in a study of prostate cancer carried out within the Netherlands Cohort Study on Diet and $\mathrm{Cancer}^{47}$. Biological mechanisms through which height and cancer risk are linked are not clear yet, but IGF-I is known to play a fundamental role in somatic growth ${ }^{48}$. A real albeit relatively weak association between height and risk of several cancers possibly exists, but the relation has been unclear for RCC because research on this topic is scarce ${ }^{48}$. It is unclear to us why sex would modify the association between height and $\mathrm{RCC}$. As far as we know, no other studies report differences between men and women. 
Another cohort study found weight at age 18 years and weight gain since age 18 to be independent risk factors for women ${ }^{15}$. Our results on BMI at age 20 and BMI change between young adulthood and baseline do not support the hypothesis that BMI at young adulthood is an independent risk factor of RCC, but BMI gain might be. However, BMI at age 20 and BMI gain between age 20 and baseline were retrospectively reported, which means recall bias might have been present. However, the effect of the recall bias will be nondifferential since only incident cases are included in the analyses, and would thus result in attenuated RRs for these factors.

Only the International Renal Cell Cancer study ${ }^{19}$, a large case-control study, reported a positive association between energy intake and RCC risk, but this association might have been due to recall bias. In the current study, no association was observed between energy intake and RCC. This is in line with the findings of another cohort study ${ }^{15}$. This is remarkable, since a high BMI is associated with an increased risk of RCC and a high $B M I$ results from excess energy intake in relation to energy expenditure ${ }^{22}$. This might be explained by the fact that energy intake tends to be underreported by overweight persons ${ }^{49}$. It might also be possible that measurement error concealed a possible effect of energy intake on RCC. The validity of reported energy intake in our study was checked by comparing results of the food frequency questionnaire with 3-day diaries completed at three time points during a calendar year. Reported intakes were, on average, $300 \mathrm{kcal}$ lower than those reported by means of the diaries. However, the questionnaire was able to rank subjects according to their energy intake ${ }^{34}$. Energy intake does not seem to be an independent risk factor for RCC in the current study or in the other cohort study that reported on energy intake, but replication, preferably by
other cohort studies, is desirable.

We did not find a clear association of physical activity and risk of RCC. Results of other studies are also inconsistent $t^{16,20-22,50}$. In general, there has been little standardization of the methods used for assessing physical activity in epidemiological studies, and few methods have been appropriately tested for reliability and validity. The use of crude measures of physical activity is likely to result in measurement error and difficulty in determining the true nature of the relation between physical activity and cancer risk ${ }^{5 !}$. Our measures for nonoccupational physical activity might have been affected by nondifferential misclassification, since it is socially desirable to be active. Thus, persons engaging in little or no activity may have overestimated their nonoccupational physical activity. The result of nondifferential misclassification is also possible that the effect in association of leisure-time physical activity with women has been reported ${ }^{52}$, which would suggest that the risk $\mathrm{BMI}$ in men and decreased for higher levels of (leisure-time) phgest that the risk of RCC should be direction of a possible protective effectime) physical activity. Our results point in the though not as clearly as the results reported bysical activity on risk of RCC for men, et al. was restricted to male smokers; thus, its results not be generalizable. Furthermore, 
there were only five cases in the highest leisure-time physical activity category, and men with a higher level of recreational physical activity showed a healthier lifestyle (i.e., smoked less) ${ }^{21}$. A more standardized manner for investigating the role of physical activity in large study groups might contribute to an unraveling of the role of physical activity.

In summary, our results confirm an increased risk of RCC with BMI, while BMI gain between young adulthood and baseline may also increase RCC risk. An effort should be undertaken to elucidate possible underlying mechanisms between factors such as BMI, BMI gain in adulthood, physical activity and energy intake and cancer risk, specifically RCC risk.

\section{Acknowledgements}

This study was financially supported by the Dutch Cancer Society and the Dutch Kidney Foundation (grant C99.1863). The authors thank the staffs of the Dutch regional cancer registries and the Netherlands national database for pathology (PALGA) for providing incidence data. They also thank Dr. E. Dorant and C.A. de Brouwer for their preparatory work for this study; Dr. A. Volovics and Dr. A. Kester for statistical advice; S. van de Crommert, H. Brants, J. Nelissen, C. de Zwart, M. Moll, W.van Dijk, M. Jansen and A. Pisters for data entry and processing; and H. van Montfort, T, van Moergastel, L. van den Bosch, and R. Schmeitz for programming assistance. 


\section{References}

1. Bergstrom A, Hsieh $C C$, Lindblad P, Lu CM, Cook NR, Wolk A. Obesity and renal cell cancer-a quantitative review. Br J Cancer 2001;85:984-90.

2. Bergstrom $A$, Pisani $P$, Tenet $V$, Wolk A, Adami HO. Overweight as an avoidable cause of cancer in Europe. Int I Cancer 2001:91:421-30.

3. Muscat JE, Hoffmann D, Wynder EL. The epidemiology of renal cell carcinoma. A second look. Cancer 1995;75:2552-7.

4. Benhamou $\mathrm{S}$, Lenfant $\mathrm{MH}$, Ory Paoletti $\mathrm{C}$, Flamant R. Risk factors for renal-cell careinoma in a French case-control study. Int J Cancer 1993;55:32-6.

5. McLaughlin JK, GaO YT, Gao RN, et al. Risk factors for renal-cell cancer in Shanghai, China. Int J Cancer 1992;52:562-5.

6. Goodman MT, Morgenstern H, Wynder EL. A case-control study of factors affecting the development of renal cell cancer. Am J Epidemiol 1986;124:926-41.

7. Shapiro JA, Williams MA, Weiss NS. Body mass index and risk of renal cell carcinoma. Epidemiology 1999;10:188-91.

8. Yuan JM, Castelao JE, Gago Dominguez M, Ross RK, Yu MC. Hypertension, obesity and their medications in relation to renal cell carcinoma. Br J Cancer 1998;77:1508-13.

9. Boeing $\mathrm{H}$, Schlehofer $\mathrm{B}$, Wahrendorf $\mathrm{H}$. Diet, obesity and risk for renal cell carcinoma: results from a case control-study in Germany. Z Enahrungswiss 1997;36:3-11.

10. Tulinius $\mathbf{H}$, Sigfusson $N$, Sigvaldason $H$, Bjarnadottir $K$, Tryggvadottir L. Risk factors for malignant diseases: a cohort study on a population of 22,946 Icelanders. Cancer Epidemiol Bionnarkers Prev 1997;6:863-73.

11. Asal NR, Risser DR, Kadamani S, Geyer JR, Lee ET, Cherng N. Risk factors in renal cell carcinoma: I. Methodology, demographics, tobacco, beverage use, and obesity. Cancer Detect Prew 1988;11:359-77.

12. Maclure $M$, Willett $W$. A case-control study of diet and risk of renal adenocarcinoma. Epidemiology $1990 ; 1: 430-40$.

13. Chow WH, Gridley G, Fraumeni JF, Jr., Jarvholm B. Obesity, hypertension, and the risk of kidney cancer in men. N Engl J Med 2000;343:1305-11.

14. Kreiger N, Marrett LD, Dodds L, Hilditch S, Darlington GA. Risk factors for renal cell carcinoma: results of a population-based case-control study. Cancer Causes Control $1993 ; 4: 101-10$.

15. Prineas $\mathrm{RJ}_{*}$ Folsom $\mathrm{AR}_{\text {; }}$ Zhang ZM, Sellers TA, Potter J. Nutrition and other risk factors for renal cell carcinoma in postmenopatusal women. Epidemiology 1997;8:31-6.

16. Mellemgaard A, Lindblad $P$, Schlehofer $B$, et al. Intemational renal-cell cancer study. III. Role of weight, beight, physical activity, and use of amphetamines. Int $J$ Cancer $1995 ; 60: 350-4$.

17. McLaughin JK, Lipworth L. Epideniologic aspects of renal cell cancer. Semin Oncol 2000;27:115-23.

18. Wolk A, Lindblad $\mathbb{P}$, Adami HO. Nutrition and renal cell cancer. Cancer Causes Control
$1996,7,5-18$.

19. Wolk A, Gridley $G$, Niwa $S$, et al. International renal-cell cancer study. VII. Role of diet Int J Cancer 1996;65:67-73.

20. Bergstrom A, Terry $P$, Lindblad $P$, et al. Physical activity and risk of renal cell cancer. Int $J$ Cancer 2001:92:155-7.

21. Mahabir S, Leitzmann MF, Pietinen P, Albanes D, Virtamo J, Taylor PR. Physical activity and renal cell cancer risk in a cohort of male smokers. Int J Cancer 2004;108:600-5.

22. Vainio $\mathrm{H}$, Bianchini $\mathrm{F}$, eds. Weight control and physical activity. Lyon: IARC press, 2002. 
23. Yu H, Rohan $\mathrm{T}$. Role of the insulin-like growth factor family in cancer development and progression. J Natl Cancer Inst 2000;92:1472-89.

24. Allen NE, Appleby PN, Kaaks R, Rinaldi S, Davey GK, Key TJ. Lifestyle determinants of serum insulin-like growth-factor-I (IGF-I), C-peptide and hormone binding protein levels in British women. Cancer Causes Control 2003;14:65-74.

25. Baibas N, Bamia C, Vassilopoulou E, Sdrolias J, Trichopoulou A, Trichopoulos D. Dietary and lifestyle factors in relation to plasma insulin-like growth factor I. in a general population sample. Eur J Cancer Prev 2003;12:229-34.

26. Chang $\mathrm{S}$, Wu X, Yu H, Spitz MR. Plasma concentrations of insulin-like growth factors among healthy adult men and postmenopausal women: associations with body composition, lifestyle, and reproductive factors. Cancer Epidemiol Biomarkers Prev 2002;11:758-66.

27. Holmes MD, Pollak MN, Hankinson SE. Lifestyle correlates of plasma insulin-like growth factor I and insulin-like growth factor binding protein 3 concentrations. Cancer Epidemiol Biomarkers Prev 2002; 1 1:862-7.

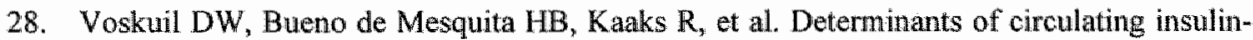
like growth factor (IGF)-I and lGF binding proteins 1-3 in premenopausal women: physical activity and anthropometry (Netherlands). Cancer Causes Control 2001;12:951-8.

29. Gago-Dominguez M, Castelao JE, Yuan JM, Ross RK, Yu MC. Lipid peroxidation: a novel and unifying concept of the etiology of renal cell carcinoma (United States). Cancer Causes Control 2002;13:287-93.

30. Van den Brandt PA, Goldbohm RA, Van 't Veer P, Volovics A, Hermus R., Sturmans F. A large-scale prospective cohort study on diet and cancer in The Netherlands. J Clin Epidemiol 1990;43:285-95.

31. Volovics $A$, wan den Brandt PA. Methods for the analyses of case-cohort studies. Biom J $1997 ; 39: 159-214$

32. Van den Brandt PA, Schouten LJ, Goldbohm RA, Dorant E, Hunen PM. Development of a record linkage protocoll for use in the Dutch Cancer Registry for Epidemiological Research. Int J Epidemiol 1990;19:553-8.

33. Goldbohm RA, Van den Brandt PA, Dorant E. Estimation of the coverage of Dutch municipalities by cancer registries and PALGA based on hospitall discharge data. Tijdschr Soc Gezondheidsz 1994;72:80-4.

34. Goldbohm RA, van den Brandt PA, Brants HA, et al. Validation of a dietary questionnaire used in a large-scale prospective cohort study on diet and cancer. Eur I Clin Nutr 1994;48:253-65.

35. Goldbohm RA, van 't Veer P, van den Brandt PA, et al. Reproducibility of a food frequency questionnaire and stabillity of dietary habits determined from five annually repeated measurements. Eur J Clin Nutr 1995;49:420-9.

36. NEVO table. Dutch food composition table 1986-1987. The Hague, The Netherlands: Voorlichtingsbureau woor de Voeding, 1986.

37. Hettinger Th, Mueller BH, Gebhard Hj. Ermittlung des Arbeitserergieumsatzes bei Dynamisch Muskulaerer Arbeit. Calculation of metabolic activity in dynamic musculoskeletal labor. Dortmund: Federal Institute of Occupational Safety and Health, 1989.

38. Dirx MJ, Voorrips LE, Goldbohm RA, van den Brandt PA. Baseline recreational physical activity, history of sports participation, and postmenopausal breast carcinoma risk in the Netherlands Cohort Study. Cancer 2001;92:1638-49.

39. Schoenfeld D. Partiall residuals for the proportional hazards regression model. Biometrika $1982 ; 69: 239-41$.

40. Lin DY, Wei LJ. The robust inference for the Cox Proportional Hazards Model. J Am Stat Assoc 1989;84:1074-8. 
41. Wolk $A$, Gridley $G$, Sverisson $M$, et al. A prospective study of obesity and cancer risk (Sweden). Cancer Causes Control 2001;12:13-21.

42. Talamini $R$, Baron $A E, B$ arra $S$, et al $A$ case-control study of risk factor for renall cell cancer in northern Italy. Cancer Causes Control 1990;1:125-31.

43. Kuczmarski MF, Kuczmarski RJ, Najjar M. Effects of age on validity of self-reported height, weight, and body mass index: findings from the Third National Health and Nutrition Examination Survey, 1988-1994. J Am Diet Assoc 2001; 101:28-34.

44. Niedhammer I, Bugel $I$, Bonenfant $S$, Goldberg $M$, Leclere A. Validity of self-reported weight and height in the French GAZEL cohort. Int J Obes Relat Metab Disord $2000 ; 24: 1111-8$.

45. Van den Brandt PA, Dirx MJ, Ronckers CM, Van den Hoogen P, Goldbohm RA. Height, weight weight change, and postmenopausal breast cancer risk: The Netherlands Cohort Study. Cancer Causes Control 1997;8:39-47.

46. Schouten LJ, Goldbohm RA, Van Den Brandt PA. Height, weight, weight chrnge, and ovarian cancer risk in the Netherlands cohort study on diet and cancer. Am I Epidemiol $2003 ; 157: 424-33$.

47. Schuurman AG, Goldbohm RA, Dorant E, van den Brandt PA. Anthropometry in relation to prostate cancer risk in the Netherlands Cohort Study. Am J Epidemiol 2000; 151:541-9.

48. Gunnell D, Okasha M, Smith GD, Oliver SE, Sandhu J, Holly JM. Height, leg length, and cancer risk: a systematic review. Epidemiol Rev 2001;23:313-42.

49. Seidell JC. Dietary fat and obesity: an epidemiologic perspective. Am J Clin Nutr $1998 ; 67: 546 \mathrm{~S}-50 \mathrm{~S}$.

50. Mellemgaard A, Engholm G, McLaughlin $J K$, Olsen $J H$. Risk factors for renal-cell carcinoma in Denmark. III. Role of weight, physical activity and reproductive factors. Int J Cancer $1994 ; 56: 66-71$.

51. Friedenreich CM, Orenstein MR. Physical activity and cancer prevention: etiologic evidence and biological mechanisms.. J Nutr $2002 ; 132: 34565-64 \mathrm{~S}$.

52. Lahti Koski $M$, Pietinen $P$, Helliovaara $M$, Vartiainen $\mathbb{E}$. Associations of body mass index and obesity with physical activity, food choices, alcohol intake, and smoking in the 19821997 FINRISK Studies. Am J Clin Nutr 2002;75:809-17. 


\title{
Vegetable and fruit consumption and risk of renal cell carcinoma: results from the Netherlands cohort study
}

\author{
Boukje A.C. van Dijk \\ Leo J. Schouten \\ Lambertus A.L.M. Kiemeney \\ R. Alexandra Goldbohm \\ Piet A. van den Brandt \\ Int J Cancer 2005;117(4):648-54
}




\section{Abstract}

Vegetable and fruit consumption is generally inversely associated with various cancer types, including Renal Cell Carcinona (RCC). The Netherlands cohort study on diet and cancer (NLCS) consists of 120,852 men and women, aged 55-59, who filled-out a self-administered questionnaire that includes a 150-item foodfrequency guestionnaire and additional questions on lifestyle factors at baseline in 1986. A case-cohort approach was used. After 9.3 years of follow-up, 275 microscopically confirmed incident cases were identified. Subjects with incomplete or inconsistent dietary data were excluded, leaving 260 RCC cases for analyses on frut consumption and $249 \mathrm{RCC}$ cases for analyses on vegetable consumption. Incidence rate ratios (RR) and corresponding $95 \%$ confidence intervals $(\mathrm{CD}$ ) were estimated using Cox proportional hazard models. RRs for exposure variables are expressed per increment of $25 \mathrm{~g} / \mathrm{day}$ and are adjusted for age, sex, smoking, body mass index and history of hypertension at baseline. The RRs for vegetable consumption were firther adjusted for fruit consumption and wice versa. Total vegetable and fruit consumption (RR: 1.00;95\% Cl: $0.97-1.02$ ), vegetable (RR: 1.00; 95\% Cl: 0.96-1.06) and fruit consumption (RR: $1.00 ; 95 \%$ CI: 0.97\% 4.03) were not associated with RCC risk. Also, no association existed for botanical subgroups of vegetables and trut. For 30 individual vegetables and fruits, we observed one that significantly increased risk (mandarin consumption, RR: $1.76 ; 95 \% \mathrm{CI}: 1.28-2.42$ ), which must be regarded cautiously because of multiple testing. These results suggest the absence of an association between vegetable andior fruit consumption and RCC risk. 


\section{Introduction}

In general, vegetable and fruit consumption is assumed to reduce risk of various cancer types. Most reviews on Renal Cell Carcinoma (RCC) also conclude that vegetable and fruit consumption may reduce $\mathrm{RCC}$ risk ${ }^{1-5}$. Statistically significant reduced risks for $\mathrm{RCC}$ have been reported for the highest tertile of vegetable and fruit consumption ${ }^{6}$, for vegetable and fruit consumption but restricted to $\mathrm{men}^{7}$, for cruciferous/dark green vegetables $^{8}$, for vegetable and vegetable juice consumption ${ }^{9}$, for carrot consumption ${ }^{10}$ for root vegetable and banana consumption" and for fruit consumption ${ }^{12,13}$. Furthermore, two studies showed estimates pointing in the direction of a protective effect, but associations were not statistically significantly different from one $e^{14,15}$. Finally, three studies observed null associations ${ }^{16-18}$.

Antioxidant vitamins, fibres or enzyme inducers present in vegetable and fruits might be responsible for this preventive effect ${ }^{5}$. Plants rich in nitrosation inhibitors, antioxidants or enzyme inducers, e.g., ascorbate and polyphenols or carotenoid-rich vegetables, garlic and cruciferous vegetables may thus be most effective in preventing cancer ${ }^{5}$. The biological plausibility that vegetable and fruit consumption reduces cancer risk is present, but so far reported results do not support this notion unequivocally ${ }^{6-18}$. We investigated total vegetable and fruit consumption, as well as the consumption of botanical groups of vegetables and fruits and individual vegetables and fruits and RCC risk in a large cohort. For some important risk factors stratified analyses will be carried out, e.g. for smoking because smoking increases oxidative stress and a more pronounced protective effect has been reported for never smokers ${ }^{12.15}$.

\section{Materials and methods}

\section{Netherlands Cohort Study}

The Netherlands Cohort Study on diet and cancer is a large cohort study that started in September 1986 . The study design has been reported in detail elsewher ${ }^{19}$. Briefly, the cohort included 120,852 men and women aged 55-69 years in 1986. An elderly cohort was selected because dietary habits (and their contrasts) are stabilized, and such a cohort will yield sufficient cases for meaningful analyses within a reasonable time period $^{19}$. The case-cohort design was used, which means that a subcohort of 5,000 men and women was randomly sampled from the cohort after baseline exposure measurement to estimate the number of person-years for the entire cohort, whereas cases were enumerated for the entire cohor ${ }^{20}$.

\section{Follow-up for incident cancers and vital status}

The entire cohort was followed for incident cancer by computerized record linkage with the Netherlands Cancer Registry and PALGA, a national database of pathology 
reports. The method of record linkage to obtain information on cancer incidence has been described previously ${ }^{21}$. The completeness of cancer follow-up was estimated to be more than $96 \%$. After 9.3 years of follow-up 275 incident RCC cases have been identified.

The subcohort has been followed up for vital status information biennially by mail. The vital status of subcohort members who did not respond was completed by contacting. municipal population registries. Only two male subcohort members were lost to followup after 9.3 years of follow-up and were censored. Subcohort members with prevalent cancer at baseline (other than skin cancer) were excluded from analyses, leaving 4,779 subcohort members.

\section{Questionnaire}

At baseline, all cohort members completed a mailed, self-administered questionnaire on dietary habits, lifestyle, smoking, personal and family history of cancer and demographic data. The dietary section of the questionnaire was a 150 -item semiquantitative food-frequency questionnaire, which was validated against 3-day diaries completed at three time points during a calendar year ${ }^{23}$. The questionnaire concentrated on the habitual consumption of food and beverages during the year preceding the start of the study. With regard to vegetable consumption, participants were asked to report their frequency of consumption of a number of vegetables, both in summer and in winter. They could choose one of six categories, ranging from "never or less than once a month" to "three to seven times per week". Usual serving sizes were asked for string beans and cooked endive only, the mean of which served as an indicator for serving sizes of all cooked vegetables. This procedure was chosen because in a pilot study (based on an extensive dietary history with food models and photos used to estimate individual portion sizes) it was shown that serving sizes of different types of cooked vegetables were correlated within subjects ${ }^{24}$. To derive an individual serving size for each type or vegetable the indicator serving size was multiplied with a type-specific factor calculated from the same pilot study data as the ratio of the means of the specific to the indicator serving sizes ${ }^{24}$. For tomatoes and sweet peppers, consumption was asked in pieces per week and month, respectively, during summer and winter. With regard to fruit consumption, frequencies varying from "never or less than once a month" to "six or seven days per week" and amounts consumed could be reported for mandarins, oranges, grapefruits, grapes, bananas, apples/pears and strawberries. Using standard portion sizes, these frequencies and amounts have been converted to consumption in grams per day. The choice of items for inclusion in the questionnaire was such that it covered almost all vegetables and fruits eaten regularly, with the exceptions of chicory, red cabbage and cucumber. Broccoli was a rarely available vegetable in 1986 and therefore not included. However, an open-ended question on other foods eaten on a regular basis was included. Participants could write down how many times per week they ate such a food and how much they were used to eat on each occasion. 
According to criteria published before ${ }^{23}$, subjects with incomplete or inconsistent dietary data were excluded; $260 \mathrm{RCC}$ cases and 4,441 subcohort members remained for analyses on fruit consumption. In addition, we computed an error index based on the consistency of responses on vegetable questions. Questions on vegetable consumption appeared early in the questionnaire, which led some subjects to making mistakes on these particular items, while items appearing further along in the questionnaire were filled out without problems. When the vegetable error index exceeded a certain value, i.e, more than three errors, subjects were excluded from analyses on vegetable consumption. Therefore, data analysis regarding vegetable consumption was based on 249 RCC cases and 4,201 subcohort members.

\section{Data analysis}

Rate ratios (RRs) were calculated for total vegetable and fruit consumption, total vegetable consumption, total fruit consumption, cooked vegetable consumption and raw vegetable consumption. RRs were also calculated for botanical groups of vegetables and fruits (composition of botanical groups is shown in Appendix 1), with the exception of groups based on one main constituent (carrots, beets, tomatoes, grapes, bananas and strawberries). These were analysed in the individual vegetable and fruit analysis only. RRs were calculated per increment of $25 \mathrm{~g} /$ day. Also, subjects were classified into quintiles and tertiles of vegetable or fruit consumption, based on the distribution in the subcohort. Analyses for total vegetable and fruit consumption, total vegetable and total fruit consumption have been repeated excluding the first two years of follow-up to evaluate whether pre-clinical RCC influenced results.

Based on the literature and previous analyses, considered confounders were age (continuous), sex, cigarette smoking (current smoker yes or no, number of smoking years and number of cigarettes a day), alcohol intake, body mass index (BMI), history of hypertension, physical activity, energy intake and social economic status (SES) based on education. We did not adjust for family history of RCC (present or not in a first-degree relative) since only 49 participants (4 cases and 45 subcohort members) reported a first-degree relative with RCC. Age and sex were included in all analyses. Factors that statistically significantly contributed to the model were entered in the multivariable model, leaving BMI and a history of hypertension. Smoking was also entered since some of the smoking variables to describe the smoking status satisfied this criterion as well. Moreover, these factors are well known risk factors of RCC, and may be associated with a "healthy" lifestyle, which may also be associated with vegetable and fruit consumption. For all analyses on vegetable consumption, fruit consumption was also included as a confounder and vice versa. We investigated possible interaction by sex by entering an interaction term in the model and assessing the significance of this term using the Wald test. Since no interaction on RCC risk between sex and dietary intakes was observed, results are shown for men and women combined. Furthermore, total vegetable and fruit consumption, vegetable consumption 
and fruit consumption are presented stratified by smoking status (never, ex- or current smoker), BMI ( $<25 \mathrm{~kg} / \mathrm{m}^{2}$ or $\left.\geq 25 \mathrm{~kg} / \mathrm{m}^{2}\right)$ and a history of hypertension (yes or no).

RRs and corresponding 95 percent confidence intervals (C) for RCC were estimated using Cox proportional hazard models processed with the STATA statistical software package (STATA statistical software, Release 7, STATA Corporation, College Station, TX, USA, 2001) after testing the proportional hazards assumption using scaled Schoenfeld residuals ${ }^{25}$. The proportional hazards assumption was not rejected. Standard errors were estimated using the robust Huber-White sandwich estimator to account for additional variance introduced by sampling from the cohort ${ }^{26}$. To obtain $p$ values for dose-response trends, ordinal exposure variables were fitted as continuous terms. Two sided $p$ values are reported throughout this paper.

\section{Results}

The mean age (standard deviation) was 62.1 (3.9) for cases and 61.4 (4.2) for subcohort members. Sixty-five $\%$ of cases were male, compared to $49 \%$ of subcohort members. The mean BMI was somewhat higher for cases than for subcohort members (25.5 $\mathrm{kg} / \mathrm{m}^{2}$ compared to $\left.25.1 \mathrm{~kg} / \mathrm{m}^{2}\right)$. Almost a third $(30 \%)$ of the cases and approximately a quarter $(26 \%)$ of subcohort members reported a history of hypertension.

Also, cases were more often current smokers ( $38 \%$ compared to $29 \%$ ) or ex-smokers ( $38 \%$ compared to $35 \%$ ) and smoked more and longer than subcohort members (within the strata of ex- and current smokers).

No statistically significant interaction was shown for sex and total vegetable and fruit consumption ( $p$ value $=0.40$ ), for sex and vegetable consumption ( $p$ value $=0.12$ ) or for sex and fruit consumption ( $p$ value $=0.99$ ), so RRs for $\mathrm{RCC}$ were callculated for men and women combined.

Differences in vegetable consumption between cases and subcohort members were small (Table 3.1). However, mean fruit consumption was somewhat lower for cases than for subcohort members and this difference was present in all fruit groups (Table 3.1).

Table 3.2 shows means of vegetable and fruit consumption for never, ex- and current smokers, for a BMI $<25$ and $\geq 25$ and for a positive history of hypertension or not (Table 3.2). Similar means were observed for vegetable consumption in different smoking groups and for strata of BMI and a history of hypertension. Mean fruit consumption was higher in never smokers. In the stratum of current smokers, cases ate more vegetables and less fruit than subcohort members. Among never smokers, cases consumed less fruit than subcohort members (Table 3.2). Fruit consumption was somewhat lower for cases with a $\mathrm{BMI}<25$ (Table 3.2). 
Table 3.1 Mean daily vegetable and fruit consumption among RCC cases and subcohort nuember ant baselime, Netherlands Cohort Study on Diet and Cancer, 1986-1995.

\begin{tabular}{lcc}
\hline Exposure variables: & $\begin{array}{c}\text { Cases } \\
\text { Mean (SD) }\end{array}$ & $\begin{array}{c}\text { Subcohort } \\
\text { Mean (SD) }\end{array}$ \\
\hline Total vegetables \& fruit" $^{\mathrm{t}}$ & $350.5(141.3)$ & $362.1(151.9)$ \\
Total vegetables $^{\mathrm{a}}$ & $190.4(76.7)$ & $188.4(75.6)$ \\
Cooked vegetables $^{\mathrm{a}}$ & $152.4(65.3)$ & $149.3(61.3)$ \\
Raw vegetables $^{\mathrm{a}}$ & $38.0(23.7)$ & $39.1(29.6)$ \\
Legumes $^{\mathrm{a}}$ & $36.1(25.0)$ & $32.4(22.1)$ \\
Brassicas $^{\mathrm{a}}$ & $32.9(20.2)$ & $31.7(19.8)$ \\
Leafy vegetables, cooked $^{\mathrm{a}}$ & $21.9(15.5)$ & $21.3(15.8)$ \\
Leafy vegetables, raw $^{\mathrm{a}}$ & $9.1(7.9)$ & $10.0(9.0)$ \\
Allium vegetables, cooked $^{\mathrm{u}}$ & $29.6(24.8)$ & $29.1(24.3)$ \\
Total fruit $^{\mathrm{b}}$ & $161.9(112.2)$ & $175.3(119.4)$ \\
Citrus fruit $^{\mathrm{b}}$ & $73.0(71.4)$ & $77.0(74.3)$ \\
Apples, pears $^{\mathrm{b}}$ & $81.4(74.6)$ & $87.3(82.4)$ \\
\hline
\end{tabular}

"Based on 249 incident cases and 4,201 subcohort members; "Based on 260 incident cases and 4,444.1 subcohort members

Multivariable rate ratios of RCC for total vegetable and fruit consumption as well as for botanical subgroups of vegetable and fruit consumption are shown in Table 3.3. We also analysed age and sex adjusted rates, but these were not very different (data not shown). "All vegetables and fruits", "all vegetables" and "all fruits" were not (inversely) associated with RCC risk (all RRs equalled 1). RRs of RCC for these groups hardly changed after exclusion of the first two years of follow-up (data not shown).

Legume consumption was associated with an increased risk for every 25 grams of legume consumed more per day (multivariable adjusted RR: 1.14; 95\% Cl: 0.99-1.33) (Table 3.3). This increased risk was restricted to the highest quintile of legume consumption (RR: $1.31 ; 95 \%$ CI: 0.83-2.07). An increment of 25 gram per day of raw, leafy vegetables more was associated with a reduced RCC risk (RR: $0.68 ; 95 \% \mathrm{CI}$ : $0.45-1.04)$, with an indication of a decreasing risk with increasing consumption ( $p$ value for trend: 0.11 ) (Table 3.3).

Table 3,4 shows RRs of RCC for individual vegetables and fruits. No statistically significant reduced or increased risks were observed for individual vegetables. A significantly increased risk of RCC was observed for mandarin consumption (RR: 1.76; 95\% CI: 1.28-2.42). Other citrus fruits, however, were not associated with either an increased or decreased risk of $\mathrm{RCC}$ (Table 3.4). Banana consumption may be associated with a reduced RCC risk (RR: $0.85 ; 95 \%$ CI: 0.72-1.01). 
Tabie 3.2 Mean daily vegetable and fruil consumption among RCC cases and subcohor members ai baseline, according to clgarette smoking (newer, ex- or current smoker), BMI ( $<25$ and $\geq 25)$ and history of hypertension reported (yes or no), Netherlands Cohort Study on Diet and Cancer, 1986-1995.

\begin{tabular}{|c|c|c|c|c|}
\hline & \multicolumn{4}{|c|}{ Vegetable consumption } \\
\hline & $\begin{array}{l}\text { Cases } \\
\text { (N) }\end{array}$ & $\begin{array}{c}\text { Cases } \\
\text { Mean (sdl) }\end{array}$ & $\begin{array}{l}\text { Subcohort } \\
\text { members (N) }\end{array}$ & $\begin{array}{l}\text { Subcohort } \\
\text { Mean (sd) }\end{array}$ \\
\hline Never smokelr & 61 & $183.9(71.4)$ & 1,496 & $187.4(74.6)$ \\
\hline Ex-smoker & 92 & $186.5(73.4)$ & 1,525 & $192.9(74.5)$ \\
\hline Current smoket & 96 & $198.4(82.8)$ & 1,180 & $183.8(78.2)$ \\
\hline$B M I<25$ & 119 & $187.3(72.7)$ & 2,221 & $188.3(76.4)$ \\
\hline$B M D>25$ & 130 & $193.4(80.4)$ & 1,980 & $188.4(74.8)$ \\
\hline No history of hypertension & 172 & $187.7(79.5)$ & 3,118 & $186.9(74.7)$ \\
\hline \multirow[t]{3}{*}{ History of hypertension } & 77 & $196.6(70.0)$ & 1,083 & $192.6(78.3)$ \\
\hline & \multicolumn{4}{|c|}{ Fruit consumption } \\
\hline & $\begin{array}{c}\text { Cases } \\
(\mathrm{N})\end{array}$ & $\begin{array}{c}\text { Cases } \\
\text { Mean (sd) }\end{array}$ & $\begin{array}{c}\text { Subcohort } \\
\text { members }(\mathrm{N})\end{array}$ & $\begin{array}{l}\text { Subcohort } \\
\text { Mean (sd) }\end{array}$ \\
\hline Never smoker & 63 & $188.2(113.6)$ & 1,588 & $202.5(123.3)$ \\
\hline Ex-smoker & 100 & $172.2(106.3)$ & 1,594 & $173.4(117.1)$ \\
\hline Current smoker & 97 & $134.3(112.5)$ & 1,259 & $143.3(108.7)$ \\
\hline $\mathrm{BM} 1<25$ & 124 & $151.4(99.3)$ & 2,344 & $175.9(119.5)$ \\
\hline $\mathrm{BMI}>=25$ & 136 & $171.5(122.4)$ & 2,097 & $174.5(119.4)$ \\
\hline No history of hypertension & 180 & $1.61 .0(115.0)$ & 3,290 & $173.2(119.7)$ \\
\hline History of hypertension & 80 & $164.0(106.5)$ & 1,151 & $181.3(11.8 .4)$ \\
\hline
\end{tabular}

Table 3.5 shows multivariable adjusted RRs for vegetable and fruit consumption, stratified by snioking status, BMI and history of hypertension. The estimated RRs did not differ largely between strata. None of the interaction terms of smoking, BMI or history of hypertension with tertiles of total vegetable and fruit consumption, with total vegetable consumption or with total fruit consumption were statistically significant. 
Table 3.3 Multivariable adjusted rate ratios and $95 \%$ confidence intervals for $\mathrm{RCC}$ for total and subgroups of vegetable and fruit consumption, Netherlands Cohort Study on Diet and Cancer, 1986-1995.

\begin{tabular}{|c|c|c|c|c|c|c|c|}
\hline \multirow[t]{2}{*}{ Vegetable/Eruit group } & \multicolumn{5}{|c|}{ Quintile of consumption } & \multirow{2}{*}{$\begin{array}{l}p \text { walue } \\
\text { for trend }\end{array}$} & \multirow{2}{*}{$\begin{array}{l}\text { Conthimuous } \\
2.5 \mathrm{~g} \text { per day }\end{array}$} \\
\hline & $1(\text { (How })^{n}$ & 2 & 3 & 4 & 5 (high) & & \\
\hline \multicolumn{8}{|l|}{ All wegetables and fruits: } \\
\hline Median consumption (g/day) & 189 & 275 & 34.3 & 418 & $\$ 56$ & & \\
\hline Cases of RCC & 50 & 34 & 48 & $\$ 1$ & 39 & & 222 \\
\hline Personmyears & 6,601 & 6,727 & 7,016 & 6,789 & 6.979 & & 34,111 \\
\hline Multivariable adjusted $\mathbb{R R}^{b}$ & 1 & 0.69 & 0.94 & 1.01 & 0.78 & 0.79 & 1.00 \\
\hline $95 \% \mathrm{CI}$ & - & $0.44-1.09$ & $0.62 \cdot 1.42$ & $0.67-1.52$ & $0.50-1.21$ & & $0.97-1.02$ \\
\hline \multicolumn{8}{|l|}{ All wegetables. } \\
\hline Median consumption (g/day) & 104 & 145 & 178 & 217 & 287 & & \\
\hline Cases of RCC & 48 & 44 & 38 & $\$ 0$ & 42 & & 222 \\
\hline Person-years & 6,587 & 6,933 & 6,888 & 6,831 & 6,873 & & 34,111 \\
\hline Multivariable adjusted $\mathbb{R R}^{2}$ & 1 & 0.87 & 0.77 & 1.04 & 0.84 & 0.76 & 1.00 \\
\hline $95 \% \mathrm{Cl}$ & & $0.57-1.34$ & $0.49-1.19$ & $0.68-1.59$ & $0.54-1.34$ & & $0.96-1.06$ \\
\hline \multicolumn{8}{|l|}{ Cooked vegetables ${ }^{q}$} \\
\hline Median consumption (g/day) & 79 & 114 & 142 & 173 & 230 & & \\
\hline Cases of RCC & 48 & 40 & 42 & 42 & 50 & & 222 \\
\hline Pierson-years & 6,622 & 6.802 & 7,012 & 6,848 & 6,827 & & $3,4,111$ \\
\hline Multiwariable adjusted $\mathbb{R R}^{b}$ & i & 0.79 & 0.78 & 0.81 & 0.97 & 0.24 & 1.011 \\
\hline $95 \% \mathrm{Cl}$ & $=$ & $0.51-1.23$ & $0.51-1.21$ & $0.53 \times 1.25$ & $0.63-1.48$ & & $0.95-1.07$ \\
\hline \multicolumn{8}{|l|}{ Raw vegetables" } \\
\hline Median consumption ( $\mathrm{g} / \mathrm{day})$ & 8 & 22 & 34 & 48 & 76 & & \\
\hline Cases of RCC & 33 & 47 & 50 & 52 & 40 & & 2,22 \\
\hline Person-years & 6,753 & 6,802 & 6,770 & 6,905 & 6,881 & & 34,111 \\
\hline Multivariable adjusted $\mathrm{RR}^{\mathrm{b}}$ & 1 & 1.46 & 1.64 & 1.63 & 1.26 & 0.88 & 0.99 \\
\hline $95 \% \mathrm{Cl}$ & - & 0.91 .2 .33 & $1.04-2.59$ & $1.04-2.58$ & $0.78-2.06$ & & $0.89-1.09$ \\
\hline Legumes $^{\mathrm{d}}$ & & & & & & & \\
\hline Median consumption (g/day) & 10 & 19 & 28 & 38 & 60 & & \\
\hline Cases of RCC & 44 & 39 & 41 & 40 & 58 & & 222 \\
\hline Person-years & $6,58.6$ & 6,976 & 6,761 & 6,898 & 64890 & & 34,111 \\
\hline Multiwariable adjusted $\mathrm{RR}^{\mathrm{b}}$ & 1 & 0.86 & 0.92 & 0.91 & 1.31 & 0.27 & 1.14 \\
\hline $95 \% \mathrm{Cl}$ & - & $0.54-1.38$ & $0.58 \cdot 1.46$ & $0.56-1.49$ & $0.83-2.07$ & & $0.99-1.33$ \\
\hline \multicolumn{8}{|l|}{ Braissicas } \\
\hline Meduan constumption (g/day) & 10 & 20 & 28 & 38 & 57 & & \\
\hline Cases of RCC & 43 & 34 & $\$ 1$ & 52 & 42 & & 222 \\
\hline Person-years & 6,627 & 6.819 & 6,915 & 6,847 & 6,904 & & 34,111 \\
\hline Multivariable adjusted RR $^{\text {b }}$ & 1 & 0.78 & 1.12 & 1.18 & 0.90 & 0.81 & 0.98 \\
\hline $95 \% \mathrm{Cl}$ & - & $0.49-1.26$ & $0.72-1.73$ & $0.74-11.88$ & 0.54 .50 & & $0.80-1.20$ \\
\hline
\end{tabular}




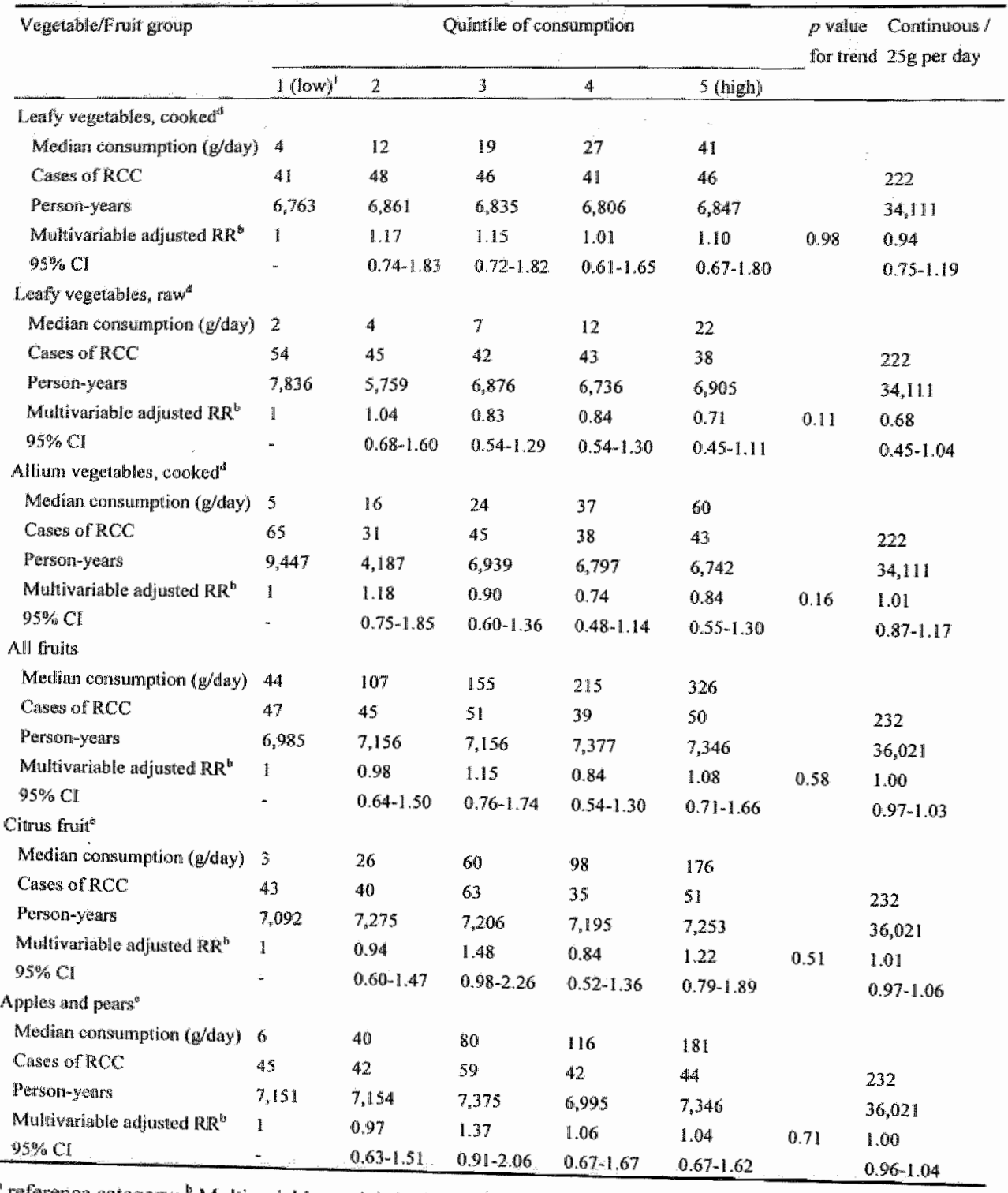

"reference category; "Multivariable models include adjustment for age, sex, current smoker (yes/no), number of cigarettes per day, number of snoking years, BMI, history of hypertension and fruit or wegetable consumption for vegetrble or frull consumption, respectively; " Cooked and raw vegetables are Altum vegetables, carrots, heets, torm "Legumes, brassicas, cooked leafy vegetables, raw leafy vegetables, in the modell" "Citrus fruit, apples and pears. grapes, bananac, and raw vegetables are simultaneously entered sibutameously entered in the model. 
Table 3.4 Rate ratios and $95 \%$ confidence intervals for $\mathrm{RCC}$ for individual vegetable and fruit consumption, Netherlands Cohort Study on Diet and Cancer, 1986-1995.

\begin{tabular}{|c|c|c|c|c|c|}
\hline Variable $^{a}$ & $\begin{array}{c}\text { Median } \\
\text { consumption } \\
\text { (grams/day) }\end{array}$ & $\begin{array}{c}\text { Age and sex } \\
\text { adjusted RR } \\
\text { per } 25 \mathrm{~g} \\
\text { increment }\end{array}$ & $95 \% \mathrm{Cl}$ & $\begin{array}{c}\text { Multiwariable } \\
\text { adjusted } \mathrm{kR}^{\mathrm{b}} \\
\text { per } 25 \mathrm{~g} \\
\text { increment }\end{array}$ & $95 \% \mathrm{Cl}$ \\
\hline Brussels sprouts & 7 & 1.16 & $0.77-1.77$ & 1.03 & $0.65-1.65$ \\
\hline Leek & 6 & 0.94 & $0.64-1.37$ & 0.92 & $0.61-1.40$ \\
\hline Sauerkraut & 5 & 11.46 & $0.75-2.84$ & 1.72 & $0.86-3.44$ \\
\hline Cauliflower & 12 & 0.93 & $0.64-1.36$ & 0.89 & $0.60-1.32$ \\
\hline Cabbage & 5 & 0.81 & $0.50-1.33$ & 0.87 & $0.51-1.47$ \\
\hline Spinach & 8 & 0.80 & $0.53-1.20$ & 0.79 & $0.51-1.22$ \\
\hline Endiwe prepared & 10 & 1.21 & $0.90 * 1.63$ & 1.07 & $0.78-1.47$ \\
\hline Red beets & 6 & 0.84 & $0.53-1.32$ & 0.95 & $0.60-1.49$ \\
\hline Carrots prepared & 7 & 0.98 & $0.65-1.47$ & 0.92 & $0.60-1.43$ \\
\hline String and sliced beans & 17 & 1.16 & $0.94-1.43$ & 1.17 & $0.94-1.46$ \\
\hline Broad beans & $\mathbb{1}$ & 1.20 & $0.78-1.87$ & 1.06 & $0.66-1.68$ \\
\hline Kale & 2 & 1.63 & $0.64-4.12$ & 1.74 & $0.66-4.61$ \\
\hline Endive raw & 0 & 0.60 & $0.25-1.43$ & 0.63 & $0.25-1.60$ \\
\hline Lettuce & 6 & 0.82 & $0.50-1.33$ & 0.77 & $0.46-1.30$ \\
\hline Carrots raw & 0 & 0.89 & $0.60-1.31$ & 0.93 & $0.61 * 1.41$ \\
\hline Rhubarb & 0 & 1.03 & $0.50-2.12$ & 1.09 & $0,52-2,28$ \\
\hline Apple sauce & 4 & 0.98 & $0.79-1.22$ & 0.98 & $0.78-1.24$ \\
\hline Onions & 11 & 1.11 & $0.92-1.33$ & 1.08 & $0.88-1.32$ \\
\hline Tomatoes & 19 & 1.13 & $0.99-1.29$ & 1.11 & $0.97-1.28$ \\
\hline Mushrooms & 4 & 0.82 & $0.32-2.08$ & 0.82 & $0.29-2.34$ \\
\hline Sweet peppers & 1 & 0.58 & $0.22-1.54$ & 0.72 & $0.28-1.87$ \\
\hline Gherkins & 0 & 0.76 & $0.49-1.18$ & 0.71 & $0.42-1.21$ \\
\hline Raisins & 0 & 0.34 & $0.04-2.58$ & 0.43 & $0.05 \cdot 3.35$ \\
\hline Mandarins & 2 & 1.77 & $1.31-2.40$ & 1.76 & $1.28-2.42$ \\
\hline Oranges & 32 & 1.00 & $0.95-1.06$ & 1.02 & $0.96-1.08$ \\
\hline Grapefruit & 0 & 0.96 & $0.83-1.12$ & 0.97 & $0.83-1.14$ \\
\hline Grapes & 1 & 0.77 & $0.53-1.12$ & 0.73 & $0.49 \cdot 1.09$ \\
\hline Bananas & 4 & 0.87 & $0.75-1.01$ & 0.85 & $0.72 \times 1.01$ \\
\hline Apples, pears & 53 & 0.99 & $0.95-1.03$ & 1.00 & $0.96 \times 1.04$ \\
\hline Strawberries & 5 & 0.88 & $0.57-1.37$ & 0.99 & $0.65-1.50$ \\
\hline
\end{tabular}

"All vegetable variables (bnissels sprouts through gherkins) are entered simultaneously in the model; rate ratios are based on 249 cases and 36,886 person-years. All fruit variables (raisins through strawberries) are entered simultaneously in the model; relative risks are based on 260 cases and 38,994 person-years. The number of cases and person years in the subcoltott is lower ifi multivariable analyses due to missing values; ${ }^{\text {th }}$ Multivariable models include adjustment for age, sex, current smoker (yes/no), number of cigarettes per day, number of smoking years, BMI, history of hypertension and fruit or vegetable consumption for vegetable or fruit consumption, respectively. 
Table 3.5 Rate ratios and 95\% confidence intervals for RCC for vegetable and fruit consumption, according to cigarette smoking (never, ex- or current smoker), BMI ( $<25$ and $\geq 25$ ) and history of hypertenision reported (yes or no), Netherlands Cohort Study on Diet and Cancer, 1986-1995.

\begin{tabular}{|c|c|c|c|c|c|c|}
\hline & \multirow{2}{*}{$\begin{array}{l}\text { No of cases / } \\
\text { person-years in } \\
\text { subcohort }\end{array}$} & \multicolumn{3}{|c|}{$\begin{array}{l}\text { Tertile of vegetable and fruit } \\
\text { consumption }\end{array}$} & \multirow{2}{*}{$\begin{array}{l}P \text { wallue } \\
\text { for } \\
\text { trend }\end{array}$} & \multirow{2}{*}{$\begin{array}{l}\text { Continuous per } \\
25 \mathrm{~g} \text { increment }\end{array}$} \\
\hline 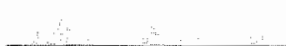 & & $1(\mathrm{low})$ & 2 & 3 (high) & & \\
\hline \multicolumn{7}{|l|}{ Vegetable consumption } \\
\hline Never smokker ${ }^{\overline{3}}$ & $59 / 12,970$ & $1(\mathrm{ref})$ & $\begin{array}{c}0.92 \\
(0.47-1.77)\end{array}$ & $\begin{array}{c}1.11 \\
(0.57-2.18)\end{array}$ & 0.77 & $\begin{array}{c}0.99 \\
(0.91-1.09)\end{array}$ \\
\hline Ex-smaker ${ }^{b}$ & $82 / 12,221$ & 1 (ref) & $\begin{array}{c}0.91 \\
(0.52-11.59)\end{array}$ & $\begin{array}{c}0.84 \\
(0.48-1.49)\end{array}$ & 0.56 & $\begin{array}{c}0.96 \\
(0.87-1.05)\end{array}$ \\
\hline Current smoker ${ }^{\text {th }}$ & $81 / 8,921$ & $1(\mathrm{ref})$ & $\begin{array}{c}0.95 \\
(0.53-1.71)\end{array}$ & $\begin{array}{c}1.24 \\
(0.72-2.15)\end{array}$ & 0.44 & $\begin{array}{c}1.05 \\
(0.98-1.13)\end{array}$ \\
\hline$B M I \propto 25^{5}$ & $112 / 18,673$ & $1(\mathrm{ref})$ & $\begin{array}{c}0.84 \\
(0.52-1.36)\end{array}$ & $\begin{array}{c}1.08 \\
(0.67-1.73)\end{array}$ & 0.77 & $\begin{array}{c}1.00 \\
(0.94-1.07)\end{array}$ \\
\hline $\mathrm{BMI} \geq 25$ & $117 / 16,564$ & $1(\mathrm{ref})$ & $\begin{array}{c}1.00 \\
(0.63-11.59)\end{array}$ & $\begin{array}{c}1.04 \\
(0.65-1.66)\end{array}$ & 0.87 & $\begin{array}{c}1.01 \\
(0.94-1.08)\end{array}$ \\
\hline $\begin{array}{l}\text { History of } \\
\text { hypertension }=\text { no }\end{array}$ & $151 / 25,241$ & 1 (ref) & $\begin{array}{c}0.86 \\
(0.57-1.31)\end{array}$ & $\begin{array}{c}1.01 \\
(0.67-1.51)\end{array}$ & 0.98 & $\begin{array}{c}1.00 \\
(0.94-1.06)\end{array}$ \\
\hline $\begin{array}{l}\text { History of } \\
\text { hypertension }=y^{*} \mathrm{es}^{\mathrm{d}}\end{array}$ & $71 / 8,870$ & 1 (ref) & $\begin{array}{c}1.02 \\
(0.54-1.92) \\
\end{array}$ & $\begin{array}{c}1.07 \\
(0.56-2.04)\end{array}$ & 0.83 & $\begin{array}{c}1.01 \\
(0.93-1.08)\end{array}$ \\
\hline \multicolumn{7}{|l|}{ Fruit consumption } \\
\hline Never smoker & $61 / 13,755$ & $1(\mathrm{ref})$ & $\begin{array}{c}0.76 \\
(0.40-1.41)\end{array}$ & $\begin{array}{c}0.71 \\
(0.38-1.33)\end{array}$ & 0.30 & $\begin{array}{c}0.98 \\
(0.93-1.04)\end{array}$ \\
\hline Ex-smoker ${ }^{t}$ & $90 / 12,734$ & $1($ ref $)$ & $\begin{array}{c}0.94 \\
(0.54-1.63)\end{array}$ & $\begin{array}{c}1.21 \\
(0.71-2.06)\end{array}$ & 0.46 & $\begin{array}{c}0.01 \\
(0.97-1.05)\end{array}$ \\
\hline Current smoker ${ }^{b}$ & $81 / 9,532$ & $1($ ref) & $\begin{array}{c}1.17 \\
(0.69-1.99)\end{array}$ & $\begin{array}{c}0.79 \\
(0.43-1.46)\end{array}$ & 0.54 & $\begin{array}{c}0.99 \\
(0.93-1.05)\end{array}$ \\
\hline$B M 1<25^{\circ}$ & $117 / 19,698$ & 1 (ref) & $\begin{array}{c}0.97 \\
(0.61-1.53)\end{array}$ & $\begin{array}{c}0.81 \\
(0.50-1.31)\end{array}$ & 0.39 & $\begin{array}{c}0.97 \\
(0.93-1.01)\end{array}$ \\
\hline $\mathrm{BMI} \geq 25^{\mathrm{e}}$ & $122 / 17,527$ & 1 (ref) & $\begin{array}{c}0.85 \\
(0.53-1.34)\end{array}$ & $\begin{array}{c}0.95 \\
(0.60-1.49)\end{array}$ & 0.82 & $\begin{array}{c}1.01 \\
(0.97-1.06)\end{array}$ \\
\hline $\begin{array}{l}\text { History of } \\
\text { hypertension }=10^{\mathrm{d}}\end{array}$ & $159 / 26,597$ & $1(\mathrm{ref})$ & $\begin{array}{c}1.04 \\
(0.70-1.55)\end{array}$ & $\begin{array}{c}0.96 \\
(0.63-1.44)\end{array}$ & 0.83 & $\begin{array}{c}1.01 \\
(0.97-1.04)\end{array}$ \\
\hline $\begin{array}{l}\text { History of } \\
\text { hypertension }=y \mathrm{es}^{\mathrm{dl}}\end{array}$ & $73 / 9,423$ & $1(\mathrm{ret})$ & $\begin{array}{c}0.81 \\
(0.44-1.46)\end{array}$ & $\begin{array}{c}0.88 \\
(0.49-1.57)\end{array}$ & 0.67 & $\begin{array}{c}0.98 \\
(0.93 \cdot 1.03)\end{array}$ \\
\hline
\end{tabular}




\section{Discussion}

Neither total vegetable and/or fruit consumption, nor consumption of a botanical group of vegetables or fruits, nor individual vegetables or fruits was associated with a decreased RCC risk in this cohort study. The only statistically significant resuit observed in 30 analyses of specific vegetables and fruits was an increased risk for mandarin consumption, which must be regarded cautiously because of multiple testing. Also, no modifying effect for smoking, BMI or a history of hypertension could be shown.

The prospective nature of a cohort study together with the completeness of follow-up, as has been achieved in this study, reduced the potential for selection bias to a minimum. Information bias, i.e, a change in (report of) dietary habits of RCC cases due to the disease, is also largely avoided in a prospective study because dietary habits were reported before the disease was diagnosed. A change in dietary habits of subjects with pre-clinical RCC at the time of completing the baseline questionnaire remains possible. An indicator of advanced disease such as weight loss, is estimated to be associated with RCC in approximately $35 \%$ of cases ${ }^{27}$. Weight loss may be induced by substances such as cytokines, insulin, inflammatory mediators etc. produced in pathologic amounts by the tumour ${ }^{27}$. However, results excluding the first two years of follow-up did not differ from presented results (including the first two years of followup), indicating that our results were not influenced by the possible presence of preclinical RCC cases. Also, more than $50 \%$ of RCCs are now detected incidentally because of the more pervasive use of non-invasive imaging for the evaluation of a variety of non-specific symptom complexes ${ }^{27}$.

Residual confounding by risk factors for RCC such as smoking or BMI is a realistic threat. Clustering of low vegetable and fruit consumption with smoking has been reported for the Dutch population ${ }^{28}$, and insufficient control of one factor will then confound the association between the other factor and RCC. We tried to model cigarette smoking habits such that they best explained $\mathrm{RCC}$ risk, resulting in a model including the habitual number of cigarettes smoked per day (smoking amount) and the number of years smoked (smoking duration), both as continuous variables. Furthermore, estimated RRs were not different for smoking strata (never, ex, current).

Correction for BMI may have influenced results because high vegetable and fruit consumption might be associated with a lower BMI (as a result of the dietary pattern). However, the correlation of BMI with total vegetable and fruit consumption is not large $(\mathrm{r}=0.025 ; p$ value $=0.0781)$. Also, mean BMI did not differ for quintiles of total vegetable and fruit consumption, vegetable consumption and fruit consumption (mean BMI range: $24.8-25.2 \mathrm{~kg} / \mathrm{m}^{2}$ ). Moreover, the $\mathrm{RR}$ and corresponding $95 \% \mathrm{CI}$ for vegetable and fruit consumption did not change after removing BMI from the model.

Although we measured vegetable and fruit consumption extensively, a potential limitation remains misclassification of exposure. Usual vegetable consumption is not very easy to assess in food-frequency questionnaires (or in other methods of dietary 
assessment), particularly if portion sizes have to be estimated. In the NLCS validation study, the FFQ was tested against 3-day diaries completed at three time points during a calendar year among 212 randomly selected subcohor members. The correlation coefficient for total vegetables consumption was $0.4^{23}$, which is moderate, but comparable to the figure reported for many other prospective studies ${ }^{29,30}$. One of the reasons for the low correlation may be the relative lack of true contrast in the frequency of vegetable consumption in a population such as the Dutch, because people are accustomed to a diet including only one hot meal per day, which almost always includes vegetables. This relative lack of contrast and thus a relatively large measurement error may result in attenuation of the estimated RR for the association of total vegetable consumption and RCC. Due to individual preferences, contrast in consumption frequency of specific vegetables is much higher, which means that attenuation is probably less important for RRs estimated for specific vegetables. It was not possible to assess validity for specific vegetables in the NLCS validation study, since 9 days of dietary recond (3-day diaries completed at three time points during a calendar year) are not sufficient to estimate consumption frequency of specific vegetables. To minimize the amount of uninformative data in addition to the general dietary exclusion criteria, we excluded subjects who appeared not to have understood how to fill out the questions on vegetable consumption, which occurred in the first part of the food-frequency questionnaire; an extreme score on the vegetable error index defined those subjects. For the same cohort, statistically significant inverse associations have been described between most categories of vegetable or fruit consumption and lung cancer ${ }^{24}$ as well as between brassica vegetables and cooked leafy vegetables and colon cancer $^{31}$, indicating that measurement error or too little contrast mosit likely do not mask a possible association.

To our knowledge, only three cohort studies ${ }^{11,14,16}$ have evaluated the relationship between vegetable and/or fruit consumption and RCC. The lowa Women's Health Study with data on 124 women reported no association for "total fruit and vegetables" and for "cruciferous or green leafy vegetables" ". In an earlier report from this study on 62 cases, a null association was reported for consumption of "fruit + vegetables", "fruit" and "vegetables" and RCC risk ${ }^{32}$. These results were confirmed in our study.

The Swedish Mammography Cohort included 122 Swedish women and observed a non-significant inverse association between the combined consumption of total fruits and total vegetables and RCC risk. Individual vegetables were associated with nonsignificantly decreased risks, except for root vegetables, which were statistically significantly inversely associated. For individual fruits, a non-significant inverse association with apples, a null association with citrus fruit, a statistically significant inverse association with banana and a non-significant increased risk with fruit juice consumption were observed". "The only agreement with the current study was the protective effect for banana consumption. A direct relationship between total phenolic content and total antioxidant activity in phytochemical extracts of different fruits has been observed, bananas ranked $6^{\text {th }}$ out of 11 fruits tested ${ }^{33}$. Bananas had the highest 
bound-W phenolics content, but the significance of bound phytochemicals in fruits to human health is not clear ${ }^{33}$. The other cohort study was conducted amongst Californian Seventh-day Adventists with 8 malle and 6 female incident cases ${ }^{14}$. Participants in this study seldom smoked (only $3 \%$ current smokers and $20 \%$ ex-smokers) and were mostly vegetarian. This study only reported on green salad and fruit consumption for which a statistically non-significant inverse association was found.

Ten case-control studies ${ }^{6-10,12,13,15,17,18}$ have evaluated the relationship between vegetable and/or fruit consumption and $\mathrm{RCC}$ risk. Three studies are based on a large number of cases and population based controls. The first was conducted in Los Angeles and reported on dark green vegetables, yellow-orange vegetables, tomatoes or tomato products, citrus fruits and citrus fruit juices in relation to RCC, based on 1,204 RCC cases and an equal number of neighbourhood controls matched by sex, date of birth (within 5 years) and ethnicity ${ }^{8}$. Only dark green vegetables showed a significant inverse association with $\mathbb{R C C}$ risk. Results were not different for smokers or never smokers, for persons with a BMI greater or less than $24.4 \mathrm{~kg} / \mathrm{m}^{2}$ or for persons with or without a history of hypertension, which was confirmed in this study. The second study was performed in Canada among 1,279 incident cases and 5,370 controls. A significant inverse association with RCC was observed with increasing total consumption of vegetables and vegetable juices for males and females combined Statistically significant inverse associations between total consumption of dark-green vegetables (broccoli and spinach) and cruciferous vegetables (broccoli, cabbage, cauliflower and Brussels sprouts) were observed for females only. Smoking did not modify the association between vegetable and fruit consumption and $\mathrm{RCC}^{9}$. The other large casecontrol study was a multicenter study from Australia, Denmark, Sweden and the United States of America (International renal-cell cancer study) ${ }^{15}$ and investigated total vegetables, orange/dark green vegetables, cruciferous vegetables, allium vegetables, total fruit, citrus and apples and pears among 1,185 cases and 1,526 controls. A significantly decreased risk in quartile 4 for orange/dark green vegetables was observed, with most estimates less than, but close to one and a more pronounced statistically significant inverse association with RCC in never smokers. Four of the case-control studies, referred to earlier, were part of the International Renal Cell Cancer Study ${ }^{12,13,17,18}$. These studies reported a statistically significantly inverse association with RCC for fruit consumption ${ }^{12,13}$ and null associations ${ }^{16-18}$. However, results from one study were not included in the aggregated article because other methods were used for dietary assessment ${ }^{13}$, while another article included a larger case group ${ }^{18}$, and a third article additionally reported on food intake 20 years before the interview (with similar results) ${ }^{12}$. Data from case-control studies from Italy, Germany and China mostly showed decreased risks with vegetable and fruit consumption ${ }^{6,7,10,13}$. Statistically significant decreased associations were only observed for carrot consumption $^{10}$, the highest tertile of green vegetable consumption ${ }^{6}$, total vegetable and total fruit consumption but confined to $\mathrm{men}^{7}$ and the highest tertile of fruit consumption ${ }^{6,13}$. None of the earlier mentioned studies reported on mandarin 
consumption, which suggests this was either not investigated or no statistically significant association was observed.

We were able to assess the independent association with specific vegetable and fruit groups and for individual vegetables and fruts by adjusting for total vegetable and/or fruit consumption. Only one cohort study ${ }^{11}$ and one hospital based case-control study also adjusted for total vegetable/fruit consumption ${ }^{6}$. All significantly reduced risks reported so far seen to be confined to a subgroup such as one specific type of vegetable or fruit or to a specific tertile quartile or quintile, which may suggest chance results due to multiple testing. In our study, statistically significant results for a quintile were also incidentally observed, but we did not observe this in multivariable adjusted analyses based on the continuous vegetable or fruit variable, or in the trend over the categories.

To our knowledge this is the largest prospective study on vegetable and fuit consumption and $\mathrm{RCC}$ risk currently available. Our results suggest the absence of an association between vegetable and fruit consumption and RCC risk.

\section{Acknowledgements}

The authors thank the staffs of the Dutch regional cancer registries and the Netherlands national database for pathology (PALGA) for providing incidence data. They also thank Dr. E. Dorant and Ms. C.A. de Brouwer for their preparatory work for this study; Dr. A. Volovics and Dr. A. Kester for statistical advice; Ms. S. van de Crommert, Ms. H. Brants, Ms. J. Nelissen, Ms. C. de Zwart, Ms. M. Moll, Ms. W.van Dijk, Ms. M. Jansen and Ms. A. Pisters for data entry and processing; and Mr. H. van Montfort, Mr. T. van Moergastel, Ms. L. van den Bosch and Mr. R. Schmeitz for programming assistance. 


\section{Appendix 1}

Composition of botanical vegetable and fruir groups.

\begin{tabular}{|c|c|}
\hline Group name & Vegetables or fruit represented in this group \\
\hline Cooked regetables & $\begin{array}{l}\text { Endive (prepared); cauliflower (prepared); kale (prepared); mushrooms } \\
\text { leek (prepared); spinach (prepared); Brussels sprouts (prepared); onion } \\
\text { (prepared); carrots (prepared); sauerkraut; beets (prepared); broad bean } \\
\text { (prepared); cabbage (prepared); sliced beans, string beans (prepared); swee } \\
\text { peppers; other vegetables prepared. }\end{array}$ \\
\hline Raw wegetables & Raw endive; lettuce; carrots (raw); tomatoes; other raw vegetables. \\
\hline Legume & Broad beans (prepared); pulses; sliced beans, string beans (prepared). \\
\hline Brassica & $\begin{array}{l}\text { Cauliflower (prepared), cabbage (prepared), kale (prepared); Bnissels } \\
\text { sprouts (prepared). }\end{array}$ \\
\hline Leafy vegetables, cooked & Endive (prepared); spinach (prepared). \\
\hline Leafy vegetables, raw & Raw endive; lettuce; cress ${ }^{a}$. \\
\hline Allium vegetables & Leek (prepared); onions (prepared); cocktail onions (sweet-sour)" garlic". \\
\hline Carrots & Carrots (prepared); canned carrots \\
\hline Beets: & Beets (prepared); beet-juice. \\
\hline Tomatoes & Tonatoes-raw; tonato-juice. \\
\hline Other cooked vegetables & Other vegetables prepared ${ }^{a}$ \\
\hline Other raw vegetables & Other raw vegetables ${ }^{a}$ \\
\hline Citrusfruit & $\begin{array}{l}\text { Lemons }{ }^{\mathrm{a}} \text {, fresh lemon juice 1; grapefruit, fresh grapefruit juice; mandarins } \\
\text { oranges, fresh orange juice. }\end{array}$ \\
\hline Grapes & Grapes (blue and white). \\
\hline Bananas & Bananas. \\
\hline Apples/pears & Applesauce; apples, pears. \\
\hline Strawberries & Strawberries. \\
\hline Other fruit and fruit juices & Other fruits and fruit juices \\
\hline
\end{tabular}

"Vegetable or fruit not specifically asked about in the questionnaire but entered in the open-ended question where participants could fill out other foods regularly eaten; ${ }^{\text {b }}$ Data derived from question on supplement use. 


\section{References}

1. Tavani A, La Vecchia C. Epidemiology of renal-cell carcinoma. J Nephrol 1997;10:93-106.

2. McLaughlin $\mathrm{KK}$, Lipworth L. Epidemiologic aspects of renal cell cancer. Semin Oncol $2000 ; 27: 115-23$.

3. Key T, Allen N, Spencer E, Trawis R. The effect of diet on risk of cancer. Lancet $2002,360,861-8$.

4. Wolk $A$, Lindblad $P$, Adami HO. Nutrition and renal cell cancer. Cancer Causes Control $1996,7: 5-18$.

5. Vainio $\mathrm{H}_{3}$ Bianchin $\mathrm{F}$, eds. Fruit and Vegetables. Lyon: IARC press, 2003.

6. Negri E, La Vechia $C$, Franceschi S, D'Avanzo B, Parazzini F. Vegetable and fruit consumption and cancer risk. Int J Cancer 1991;48:350-4.

7. McLaughlin JK, Gao YT, Gao RN, et al. Risk factors for renal-cell cancer in Shanghai, China. Int J Cancer 1992;52:562-5.

8. Yuan JM, Gago Dominguez M, Castelao JE, Hankin JH, Ross RK, Yu MC. Cruciferous vegetables in relation to renal cell carcinoma. Int J Cancer 1998;77:21 1-6.

9. Hu , Mao $Y$, White $K$. Diet and vitamin or mineral supplements and risk of renal cell carcinoma in Canada. Cancer Causes Control 2003; 14:705-14.

10. Talamini $\mathrm{R}$, Baron $\mathrm{AE}$, Barra $\mathrm{S}$, et al. $\mathrm{A}$ case-control study of risk factor for renal cell cancer in northern Italy. Cancer Causes Contro\1990;1:125-31.

11. Rashidkhani B, Lindblad P, Wolk A. Fruits, vegetables and risk of renal cell carcinoma: A prospective study of Swedish women. Int J Cancer 2005;113:451-5.

12. Lindblad P, Wolk A, Bergstrom R, Adami HO. Diet and risk of renal cell cancer: a population-based case-control study. Cancer Epidemiol Biomarkers Prev 1997;6:215-23.

13. Boeing $\mathrm{H}$, Schlehofer $\mathrm{B}$, Wahrendorf $\mathrm{J}$. Diet, obesity and risk for renal cell carcinoma: results from a case control-study in Germany. Z Ernahrungswiss 1997;36:3-11.

14. Fraser GE, Phillips RL, Beeson WL. Hypertension, antibypertensive medication and risk of renal carcinoma in California Seventh-Day Adventists. Int J Epidemiol 1990;19:832-8.

15. Wolk $A$, Gridley $G$, Niwa $S$, et al. International renal-cell cancer study. VII. Role of diet. Int J Cancer 1996;65:67-73.

16. Nicodemus KK, Sweeney C, Folsom AR. Evaluation of dietary, medical and lifestyle risk factors for incident kidney cancer in postmenopausal women. Int I Cancer 2004;108: $115-21$.

17. Mellengaard $A$, McLaughlin JK, Overvad $K$, Olsen $\mathbf{J H}$. Dietary risk factors for renal cell carcinoma in Denmark. Eur J Cancer 1996;32a:673-82.

18. Chow WH, Gridley G, McLaughlin JK, et al. Protein intake and risk of renal cell cancer. J Natl Cancer linst 1994;86:1131-9.

19. Van den Brandt PA, Goldbohm RA, Van "t Veer P, Volovics A, Hermus RJ, Sturmans F. A large-scale prospective cohort study on diet and cancer in The Netherlands. I Clin Epidemiol 1990;43:285-95.

20. Volovics A, wan den Brandt PA. Methods for the analyses of case-colort studies. Biom $J$ $1997 ; 39: 159-214$.

21. Van den Brandt PA, Schouten LJ, Goldbohm RA, Dorant $E_{3}$ Hunen PM. Development of a record linkage protocol for use in the Dutch Cancer Registry for Epidemiological Research. Int J Epidemiol 1990;19:553-8.

22. Goldbohm RA, Van den Brandt PA, Dorant E. Estimation of the coverage of Dutch municipalities by cancer registries and PALGA based on hospital discharge data. Tijdschr Soc Gezondheidsz 1994;72:80-4. 
23. Goldbohm RA, van den Brandt PA, Brants HA, et al Validation of a dietary questionnaire used in a large-scale prospective cohort study on diet and cancer. Eur J Clin Nutr $1994 ; 48: 253-65$.

24. Voorrips LE, Goldbohm RA, Verhoeven DT, et al. Vegetable and fruit consumption and lung cancer risk in the Netherlands Cohort Study on diet and cancer. Cancer Causes Control 2000;11:101-15.

25. Schoenfeld D. Partial residuals for the proportional hazards regression model. Biometrika $1982 ; 69: 239-41$.

26. Lin DY, Wei LJ. The robust inference for the Cox Proportional Hazards Model. II Am Stat Assoc 1989;84:1074-8.

27. Novick $\mathrm{AC}$, Campbell SC. 75. Renal tumors. In: Walsh $\mathrm{PC}$, Retik $\mathrm{AB}$, Darracott Vaughan Jr E, et al., eds. Campbell's Urology. eighth ed. Philadelphia: Saunders, 2002:2672-719.

28. Schuit $\mathrm{AJ}$, van Loon $\mathrm{AJ}$, Tijhuis $\mathrm{M}$, Ocke $\mathrm{M}$. Clustering of lifestyle risk factors in a general adult population. Prev Med 2002;35:219-24.

29. Smith-Warner SA, Elmer $\mathrm{PJ}$, Fosdick L, Tharp TM, Randall B. Reliability and comparability of three dietary assessment methods for estimating fruit and vegetable intakes. Epidemiology 1997;8:196-201.

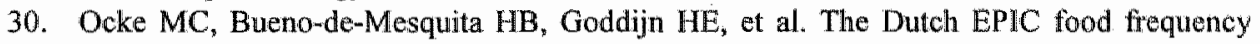
questionnaire. I. Description of the questionnaire, and relative validity and reproducibility for food groups. Int J Epidemiol 1997;26 Suppl 1:S37-48.

31. Voorrips LE, Goldbohm RA, van Poppel G, Sturmans F, Hermus RJ, van den Brandt PA. Vegetable and fruit consumption and risks of colon and rectal cancer in a prospective cohort study: The Netherlands Cohort Study on Diet and Cancer. Am J Epidemiol $2000 ; 152: 1081-92$.

32. Prineas RJ, Folsom AR, Zhang ZM, Sellers TA, Potter J. Nutrition and other risk factors for renal cell carcinoma in postmenopausal women. Epidemiology 1997;8:31-6.

33. Sun $J_{9}$ Chu YF, Wu X, Liu RH. Antioxidant and antiproliferative activities of common fruits. J Agric Food Chem 2002;50:7449-54. 


\section{4}

\section{Prevalence of von Hippel-Lindau gene mutations in sporadic renal cell carcinoma: results from the Netherlands cohort study}

Kjeld P. van Houwelingen Boukje A.C. van Dijk Christina A. Hulsbergen-van de Kaa Leo J. Schouten Hanneke J.M. Gorissen Jack A. Schalken Piet A. van den Brandt Egbert Oosterwijk BMC Cancer 2005:5:57 


\section{Abstract}

\section{Background}

Biallelic wom Hippel-Lindou (VHL) gene defects, a rate-limiting event in the carcinogenesis, occur in approximately $75 \%$ of sporadic clear-cell Renal Cell Carcinoma (RCC). We stadied the VHL mutation status in a large population-based case group.

\section{Methods}

Cases were identified within the Netherlands cohort study on diet and caneer, which includes 120,852 men and women. After 11.3 years of follow-tup, 337 incident cases with histologically confirmed epithelial cancers wore identitied. DNA was isolated from paraffin material collected from 51 pathology laboratories and revised by one pathologist, leaving material from 235 cases. WHL mutational status was assessed by SSCP followed by direct sequencing, after testing SSCP as a screening tool in a subsample.

\section{Results}

The number of mutations was significantly higher for clear-cell RCC compared to other histological types. Wa observed 131 mutations in 114 out of 187 patients $(61 \%)$ with clear-cell $\mathrm{RCC}$. The majority of mutations were truncating mutations $(47 \%)$. The mean tumor size was $72.7 \mathrm{~mm}$ for mutated tumors compared to $65.3 \mathrm{~mm}$ for wildtype tunors $(p=0,06)$. No statistically significant differences were obserwed for nuclear grade. TNM distribution or stage. In other histological types, we observed 8 mutations in 7 out of 48 patients (15\%), 1 mutation in 1 of 6 oncocytoma, 3 mutations in 2 of 7 chromophobe RCC, 2 mutations in 2 of 30 papillary RCC, no mutations in 1 collecting duct carcinoma and 2 mutations in 2 of 4 unclassified RCC.

\section{Conchusions}

WHL mutations were detected in $61 \%$ of sporadic cllear-cell RCC. VHL mutated and wildtype clear-cell RCC did not differ with respect to most parameters. 


\section{Background}

Historically, the classification of Renal Cell Cancer (RCC) was based on morphological features. The majority of RCC are of the clear cell type ( $\sim 80 \%)$; other subtypes are papillary RCC (10\%), chromophobe RRC (5\%), collecting-duct carcinoma (1\%) and unclassified RCC (3-5\%). Based on the work of numerous investigators, it became evident that $\mathrm{RCC}$ could be divided into genetically distinct classes: this resulted in the so-called Heidelberg classification, which partly overlaps the former pathological classification of RCC based on morphological criteria. The most prominent common genetic aberration for clear-cell (conventional) RCC is loss of $3 \mathrm{p}$. Characteristic for papillary RCC is trisomy of chromosomes $3 \mathrm{q}, 7,8,12,16,17,20$, and loss of the $\mathrm{Y}$ chromosome, and chromophobe $\mathrm{RCC}$ is characterized by a combination of loss of heterozygosity at chromosomes $1,2,6,10,13,17$, and $21^{1}$.

Von Hippel-Lindau (VHL) disease is a rare inherited disorder associated with, amongst others, an enhanced risk for clear-cell $\mathrm{RCC}^{2}$. The VHL gene responsible for this syndrome was identified through linkage analyses and molecular cloning and is located on chromosome $3 \mathrm{p} 25$. After its identification it became evident that the $V H L$ gene is also involved in the development of sporadic clear-cell RCC. Together with loss of the homologous chromosome $3 \mathrm{p}$ allele $(3 \mathrm{p} \mathrm{LOH}), V H L$ mutations are rate-limiting events in the carcinogenesis of clear-cell $\mathrm{RCC}^{3,4}$. Mutations have been observed in the entire gene and usually lead to a truncated inactive protein ${ }^{5}$. The $V H L$ gene is considered a tumor suppressor gene, involved in cell cycle regulation, regulation of hypoxia inducible genes and proper fibronectin assembly in extracellular matrix $x^{6,7}$. It was estimated that approximately $75 \%$ of all sporadic clear-cell RCC harbor biallelic $W H L$ defects $^{8}$. In approximately $19 \%$ of sporadic clear-cell $\mathrm{RCC}$, methylation of the VHL gene promoter appeared to be involved ${ }^{9}$. In approximately $10 \%-20 \%$ of sporadic clearcell RCC no alteration in the $V H L$ alleles was detected, indicating that other genes are involved in clear-cell RCC carcinogenesis, possibly affecting the same signaling pathway as VHL.

Several risk factors for developing $\mathrm{RCC}$ have been identified: tobacco smoking, obesity, drugs such as phenacetin, hypertension and/or its medication, and occupational exposure to trichloroethylene, gasoline, petroleum products, asbestos, and iron processing fumes. The influence of dietary factors, such as vegetable, fruit, vitamin C, carotenoid, meat and milk product consumption, is controversial ${ }^{10}$. Multiple and specific types of VHL mutations in RCC have been associated with exposure to the industrial solvent trichloroethylene ${ }^{11,12}$. Consumption of vegetables and citrus firuit decreased the frequency of $V H L$ mutations among smokers and consumption of citrus fruit decreased $V H L$ mutation frequency for all patients ${ }^{13}$. These findings and investigations in animals ${ }^{14}$ suggest that mutational patterns in the $V H L$ gene may serve as an etiological imprint to factors causing renal cancer. Thus, it may be possible to improve our etiological insight in particular risk factors when a more specific endpoint 
than "RCC" can be defined, e.g. based on histology and mutational status of a gene involved in tumor carcinogenesis.

We decided to determine the mutational status of the $V H L$ gene of RCC cases identified within a population-based cohort of 120,852 men and women aged 55-69, which was recruited in the Netherlands to study associations between dietary habits, lifestyle and cancer occurrence. To validate whether SSCP could serve as a prescreening method, SSCP and direct sequencing was exaluated in a subset of 20 patients. In this article we report on histopathological and clinical parameters and the type and number of mutations in $V H L$ observed in a large population-based sample of cases.

\section{Methods}

\section{Stucly population}

The RCC cases selected for this study were incident cases identified in the population of the Netherlands Cohort Study (NLCS) on diet and cancer. The NLCS has been described in detail elsewhere ${ }^{15}$. Briefly, this prospective study was initiated in 1986 and included 58,279 men and 62,573 women, 55 to 69 years of age, who completed a selfadministered questionnaire on diet, family history of cancer, and other risk factors for cancer at baseline. The entire cohort is being monitored for cancer occurrence by annual record linkage to the Netherlands Cancer Registry and to PALGA, a nationwide network and registry of histo- and cytopathology ${ }^{16}$. Information on sex and family history of RCC (at baseline) was retrieved from the NLCS database, while information on age at diagnosis and tumor localization was retrieved from the Netherlands Cancer Registry. Tumor stage was classified according to the 1987 revision of the UICC-TNM classification $^{17}$, using information from the cancer registry and the pathology report. Tumor size was retrieved from the pathology report.

\section{Tissue sample collection}

Paraffin material was collected after approval by the Medical Ethical Committees of Maastricht University, PALGA and the Netherlands cancer registry. From 1986 to 1997 (11.3 years follow up) 355 kidney cancer cases (ICD-O-3: C64.9) were identified. Urothelial cell carcinomas were excluded and only histologically confirmed epithelial cancers were included (ICD-O: M8010-8119, 8140-8570), leaving 337 cases. The PALGA database was also used to identify the location of tumor tissue storage in the Dutch pathology laboratories. For 273 cases, a PALGA record with information on the location of paraffin material was available at the start of the collection of paraffin blocks. The tissue samples were distributed over 51 pathology laboratories throughout the Netherlands. 
For $251 / 273$ cases $(92 \%)$ paraffin blocks were collected. Failure to retrieve material was the result of the refusal of the pathology laboratory to cooperate ( 3 laboratories with material for 10 cases), the unavailability of suitable material (i.e. only material from a biopsy, cytology or a metastasis was present) ( 8 cases), not being able to locate the paraffin block at the laboratory ( 3 cases), and for 1 case the reason was not recorded. Paraffin blocks of parallel normal tissue were collected if available. Collected archival tissue sample blocks were registered and coded using a unique identification number.

\section{Revision}

Genomic DNA was extracted from five $20-\mu \mathrm{m}$ slices from each tumor and nomal specimen. A flanking section was haematoxylin and eosin (HE) stained for histological purposes, e.g. grading and estimation of percentage of tumor cells: One experienced pathologist (CAHK) reviewed all HE stained slides. The RCC were classified according to the World Health Organization (WHO) classification of Tumours of $2002^{18}$. Nuclear grading was performed according to Fuhrman ${ }^{19}$. Grading was based on the most atypical focus in the paraffin block used for DNA extraction, with a dimension of at least one high power field.

Material of 16 cases was discarded after revision. The collected material was unsuitable for analysis, because it concerned a biopsy $(\mathrm{N}=2)$ or a metastasis $(\mathrm{N}=2)$ or no tumor tissue was present $(\mathrm{N}=4)$ or material contained less than $10 \%$ malignant cells $(\mathrm{N}=7)$ (tumor samples had to contain at least 10\% malignant cells to decrease the possibility of ignoring mutations). Material from one case was reclassified as urothelial cell carcinoma and subsequently excluded. As a result, tumor DNA from 235 cases was available for further analysis.

\section{DNA isolation}

Genomic DNA was prepared as follows: paraffin was removed with xylene and genomic DNA was extracted by salt-precipitation. Briefly, $450 \mu$ of cell lysis solution $(10 \mathrm{mM}$ Tris/ $/ \mathrm{HCl}$ (pH 7.4), $400 \mathrm{mM} \mathrm{NaCl}, 2 \mathrm{mM}$ EDTA), $25 \mu l$ of $10 \%$ SDS and $50 \mu 1$ of proteinase $\mathrm{K}$ solution $(20 \mathrm{mg} / \mathrm{ml})$ were added to the tissue samples and incubated over-night at $55^{\circ} \mathrm{C}$. Proteins were precipitated using $175 \mu$ l of saturated $\mathrm{NaCl}$, followed by centrifugation ( 2 minutes, $13.200 \mathrm{rpm}$ ). DNA was precipitated by the addition of 0.6 volumes of iso-propanol, dissolved in TE ( $\mathrm{pH} 7.4$ ) and stored at $-20^{\circ} \mathrm{C}$. The DNA concentration and purity was measured at 260 and $280 \mathrm{~nm}$.

\section{VHL mutation analysis}

PCR primers used for amplification are described in Table 4.1. Amplification of DNA for SSCP analysis and sequence analysis was performed as follows: $100 \mathrm{ng}$ of the extracted DNA was subjected to 35 cycles of PCR: $40 \mathrm{sec}$ at $92^{\circ} \mathrm{C}, 40 \mathrm{sec}$ at $\mathrm{Tm}$ and 40 $\mathrm{sec}$ at $72^{\circ} \mathrm{C}$. Exon amplification was performed in $30 \mu \mathrm{l}$ of buffer: $50 \mathrm{mM} \mathrm{KCl}, 10 \mathrm{mM}$ 
Tris-HCl (pH 9.0), $1.5 \mathrm{mM} \mathrm{MgCl2,} 1 \%$ triton X-100, 0.1\% (w/v) gelatin, $250 \mathrm{uM}$ dNTP's, 25 pmol of each primer and 1 U Taq polymerase (HT Biotechnology Ltd.). For SSCP analysis, $0.2 \mu$ of $[032 \mathrm{P}] \mathrm{dATP}(10 \mathrm{mCi} / \mathrm{ml},-3000 \mathrm{Ci} / \mathrm{mmol}$, FRMA) was added.

For SSCP analyses, $5 \mu$ of the radiolabeled PCR product was diluted in $5 \mu$ lloading buffer ( $96 \%$ formamide, $20 \mathrm{mM} \mathbb{E D T A}, 0.05 \%$ bromophenol blue and xylene cyanol), boiled for $3 \mathrm{~min}$, and quenched on ice before loading. Three $\mu$ l of each sample was loaded on a $0.5 \times \mathrm{MDE}$ gel, containing $0.6 \mathrm{x}$ TBE either with or without $10 \%(\mathrm{v} / \mathrm{v})$ glycerol. Electrophoresis was performed at room temperature at $5 \mathrm{~W}$ for MDE gels without glycerol, and at $7 \mathrm{~W}$ for $\mathrm{MDE}$ gels with $10 \%(\mathrm{v} / \mathrm{v})$ glycerol, using $0.6 \times \mathrm{TBE}$ as electrophoresis buffer. After 20 hours of electrophoresis, the gels were transferred to Whatmann $3 \mathrm{MM}$ paper (FIRMA) and dried on a gel dryer. The separated fragments were visualized by Hyperfilm-MP (FIRMA) exposure.

For sequence analysis, the PCR products were purified using the WizardTM PCR preps purification system (Promega Corp.). Sequencing was performed at the local central sequence facility using BigDye Terminator and the ABI basecaller (Applied Biosystems). Mutations were identified by visual inspection of sequences provided by the ABI basecaller, and called when unequivocally present on the sense and/or antisense strand, and when the area under the curve of peaks changed by more than $5 \%$, compared to the area under the curve of the normal signal.

Table 4.1 Primers used to amplify the $W H L$ gene.

\begin{tabular}{|c|c|c|c|c|}
\hline Name & Sequence $5^{\prime}>3$ & Exon & $\operatorname{Tm}$ & Eragment length \\
\hline Sense $3 a$ & GOT CTG GAT CGC GGA GGGA & 1 & $64^{\circ} \mathrm{C}^{\mathrm{a}}$ & $191 \mathrm{bp}$ \\
\hline Asense 4 a & GCC CGG CCT CCA TCT CCT & 1 & & \\
\hline Sensesa & AGT CGG GCG CCG AGG AGT & 1 & $64^{\circ} \mathrm{C}^{\mathrm{a}}$ & $184 b p$ \\
\hline Asense6a & CCG TCG AAG TTG AGC CAT AC & 1 & & \\
\hline Sense7a & COC AGO TCA TCT TCTGCA AT & I & $64^{\circ} \mathrm{C}^{\mathrm{b}}$ & $159 \mathrm{bp}$ \\
\hline Asense8a & CTO CTOGOT COG GCC TAAG & 1 & & \\
\hline Senseg & GTG GCT CTT TAA CAA CCT TTG C & 2 & $60^{\circ} \mathrm{C}$ & $194 \mathrm{bp}$ \\
\hline Asensul 10 & CCT GTA CTT ACC ACA ACA ACC TTA TC & 2 & & \\
\hline Sensellla & CAC TOA GGA TTT GGT TTT TGC & 3 & $55^{\circ} \mathrm{C}$ & $162 \mathrm{bp}$ \\
\hline Asiense 125 & TCC AGO TCT TTC TGC ACA TTT & 3 & & \\
\hline Sitnse $13 a$ & OAC ATC GTC AGG TCG CTC TA & 3 & $55^{\circ} \mathrm{C}$ & $150 \mathrm{bp}$ \\
\hline Asense 14a & TCA AAA GCT GAG ATG AAA CAG TG & 3 & & \\
\hline
\end{tabular}

"3\% DMSO added for $\mathrm{PCR}_{*}$ " $1.5 \% \mathrm{DMSO}$ and $2.5 \mathrm{mM} \mathrm{MgCl} \mathrm{m}_{2}$ added for $\mathrm{PCR}_{;}$" $4 \%$ DMSO and $1.0 \mathrm{mM}$ $\mathrm{MgCl}_{2}$ added for $\mathrm{PCR}$

\section{Feasibility and comparability pilot}

Twenty samples were analyzed by PCR-SSCP and direct sequencing to investigate the suitability of PCR-SSCP as a screening tool preceding direct sequencing. After evaluation, we decided to use PCR-SSCP as a screening instrument before direct 
sequencing. All remaining samples were subjected to PCR-SSCP, which was only followed by direct sequencing in case of an aberrant band pattern on the PCR-SSCP. Samples were also sequenced when equivocal PCR-SSCP results were obtained.

\section{Statistical analyses}

The overall frequency of $V H L$ mutations as well as the type of mutation and affected exon and codon were computed for all 235 cases. Differences between histological subtypes were assessed by the $\chi^{2}$-test. For clear-cell RCC, mutated and wildtype tumors were compared with respect to age at diagnosis, sex, grade, TNM classification ${ }^{17}$, stage and family history of RCC. Differences in mean values of age at diagnosis as a continuous variable were evaluated by the Student $t$-test. Differences in the categorical variables sex, family history of RCC, grade, TNM classification and stage were evaluated for significance by the $\chi^{2}$-test. A $p$ value of 0.05 or less was considered statistically significant. Statistical analyses were performed with the STATA statistical software package (STATA statistical software, Release 7, STATA corporation, College Station, TX, USA, 2001).

\section{Results}

\section{PCR-SSCP as a screening tool preceding direct sequencing}

To evaluate whether PCR-SSCP could be used to distinguish between wildtype and mutated VHL, we determined the VHL status of 20 cases by SSCP and direct sequencing (Table 4.2). SSCP and direct sequencing were mostly in agreement. In all cases where disparate results were obtained, this concerned aberrant signals in PCRSSCP, followed by a negative result by direct sequencing (Table 4.2). Most importantly, we never found a mutation in the sequence analysis after a negative PCRSSCP ( $0 \%$ false-negatives) (Table 4.2$)$. However, we are aware that the sampling size is limited, and it is known that SSCP as a screening tool is neither $100 \%$ sensitive nor specific. Therefore, we estimated the chance of a positive result on direct sequencing after a negative result on the SSCP (i.e., the chance that a mutation will be missed by using SSCP as a screening instrument). The point estimate for the percentage of falsenegatives based on SSCP is $0 \%$, with an upper confidence limit between $3.7 \%$ and $16.9 \%$, based either on the individual analyses $(\mathrm{N}=97)$, or on the number of cases $(\mathrm{N}=20)$ (see Additional file 1: Calculation of the estimated upper $95 \%$ confidence limit). Different types of mutations were identified by SSCP followed by direct sequencing in this pilot. 
Table 4.2 Mutution analysis in 20 samples by $\$ \$ \mathrm{SP}$ and direct sequencing.

\begin{tabular}{|c|c|c|c|c|}
\hline & & & \multicolumn{2}{|c|}{ Direct sequencing } \\
\hline & & & Positive & Negalive \\
\hline \multirow[t]{2}{*}{ Primerset $3 / 4$} & $\$ \$ C P$ & Positive & 0 & 5 \\
\hline & & Neggative & 0 & 15 \\
\hline \multirow[t]{2}{*}{ Primerset $5 / 6$} & SSCP & Positive & 2 & 0 \\
\hline & & Negative & 0 & 18 \\
\hline \multirow[t]{2}{*}{ Primerset $7 / 8$} & SSCP & Positive & 4 & 2 \\
\hline & & Negative & 0 & 14 \\
\hline \multirow[t]{2}{*}{ Primersel $9 / 10$} & SSCP & Positive & 3 & 0 \\
\hline & & Negative & 0 & 17 \\
\hline \multirow[t]{2}{*}{ Primerset $11 / 12$} & SSCP & Positive & 4 & 1 \\
\hline & & Negative & 0 & 15 \\
\hline \multirow[t]{2}{*}{ Primerset $13 / 14$} & $\mathrm{SSCP}$ & Positive & 2 & 0 \\
\hline & & Negative & 0 & 18 \\
\hline
\end{tabular}

\section{VHL mutations and clinical parameters}

We were able to analyze at least one tumor block for 235 patients with 236 tumors (one patient had two primary tumors). After revision by CAHK, the analyzed samples could be subdivided as follows: clear-cell RCC (188/236, 79.7\%), papillary RCC (30/236, $12.7 \%)$; chromophobe RCC (7/236,3.0\%); oncosytoma $(6 / 236,2.5 \%)$, collecting duct carcinoma $(1 / 236,0.4 \%)$, and unclassified RCC (4/236, 1.7\%). For 198 cases one paraffin block was analyzed, while for 34 cases 2 paraffin blocks were analyzed and for 3 cases 3 paraffin blocks were analyzed. In 10 cases, a different genotype was observed in different tumor blocks obtained from 1 tumor. In 6 cases, 1 sample contained wildtype $V H L$ while the other sample harbored one or more mutations. For the statistical analyses these cases were analyzed as "mutated". In 13 cases, 2 mutations in the same paraffin block were observed. In one patient with two primary tumors, both tumors showed a different mutation. In total we observed 253 outcomes (139 mutations (in 121 patients) and 114 wildtype) for 235 patients with 236 primary tumors. All 139 observed mutations are described. (see Additional file 2: Description of observed mutations $(\mathrm{N}=139)$, histological parameters and personal characteristics for 121 cases). VHL gene mutations were mostly observed in clear-cell RCC, but also in unclassified RCC (2/4); papillary RCC (2/30); chromophobe RCC ( 3 mutations in $2 / 7$ patients) and oncocytoma (1/6) (see Additional file 2: Description of observed mutations ( $N=139$ ), histological parameters and personal characteristics for 121 cases). The percentage of patients with a mutation was significantly higher for clear-cell tumors compared to tumors of other histological types $\left(\chi^{2}: 32.9 ; p\right.$ value $\left.<0.001\right)$. In the remainder of this paper, we will only consider clear-cell RCC, leaving 204 outcomes (131 mutations (in 114 patients) and 73 wildtype) for 187 patients with 188 primary tumors. Nine outcomes were mutations in intronic sequences, possibly affecting splicing. The majority of observed mutations in coding regions lead to a truncated VHL product 
(insertion/deletion mutations leading to a frameshift and nonsense mutations, 62/122) or to a deleted/inserted or altered amino acid, 47/122). The percentage of point mutations was much higher in exon $1(50.7 \%)$ than in exon 2 and $3(29.6 \%$ and $23.1 \%$, respectively).

Figure 4.1 shows the type of mutation plotted against the codon number. We observed 62 truncating mutations, which consisted of 4 nonsense mutations and 58 deletions or insertions leading to a shift of the reading frame (Figure 4.1A), 15 insertions or deletions that did not affect the reading frame (Figure 4.1B), 32 missense mutations (Figure 4.1C) and 13 silent mutations (Figure 4.1D).

Cases with a mutation were older (mean: 67.8 years; sd: 4.7 ) than cases without a mutation (mean: 67.1 ; sd: 4.6 ). The mean age difference at diagnosis was 0.8 years with a $95 \% \mathrm{Cl}$ ranging from -0.6 through 2.2 years. The percentage of men with clearcell RCC with a $V H L$ mutation was somewhat higher than the percentage of males among patients with a clear-cell RCC without a $V H L$ mutation, $63.2 \%$ vs. $53.4 \%\left(\chi^{2}\right.$ : $1.75 ; p$ value: 0.19 ).

The mean tumor size was $72.7 \mathrm{~mm}$ for tumors with a $V H L$ mutation compared to 65.3 mm for tumors without a $V H L$ mutation. The difference was $7.3 \mathrm{~mm}$ with a $95 \% \mathrm{Cl}$ from $-2.1 \mathrm{~mm}$ through $16.8 \mathrm{~mm}$. Other tumor parameters for patients with a primary clear-cell RCC with or without a VHL mutation are shown in Table 4.3. We did not observe a difference in nuclear grade, $T, N, M$, or stage between mutated and wildtype tumors.

For 3 patients, a positive family history was reported; 2 of these patients (Sample id's: 1003 and 306/1600) had a clear-cell tumor harboring a mutation. One patient with a papillary tumor reported a positive family history; no mutations in the $V H L$ gene were observed in the corresponding tumor sample. Obviously, these numbers are too small to engage in statistical testing. 


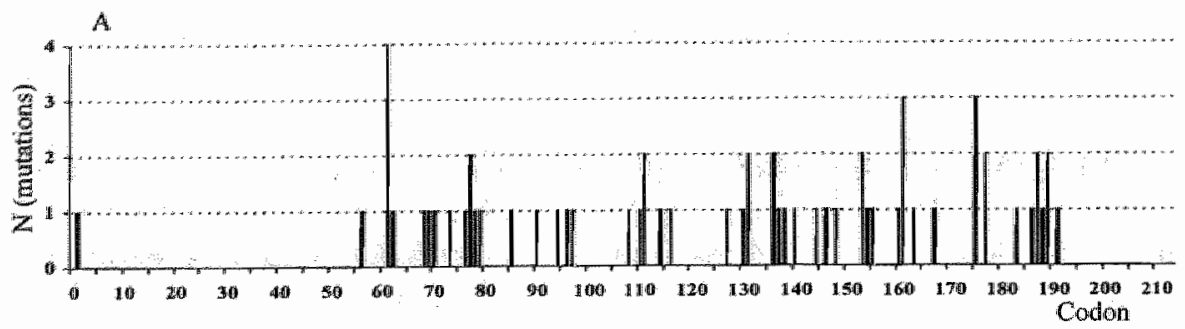

B
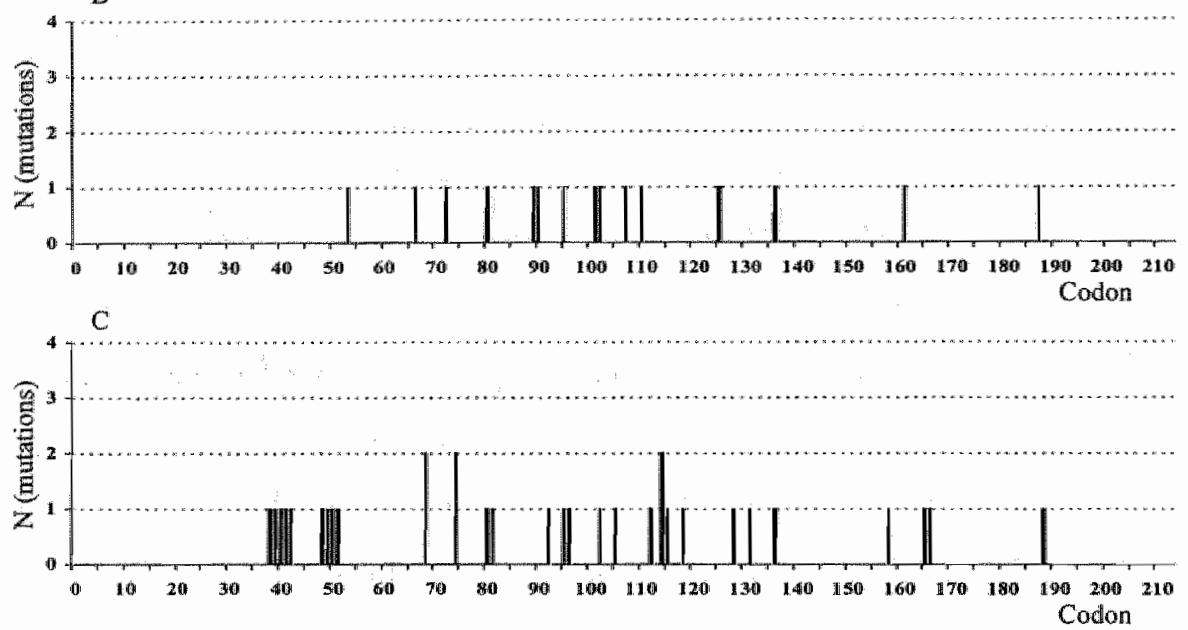

D

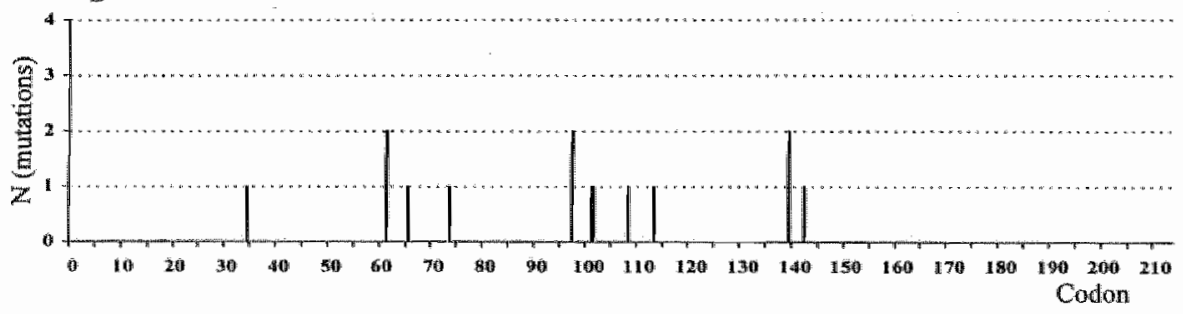

Figure 4.1 Type of mutation plotted against the codon number.
A. Truncating mutations (Frameshift \& Nonsense mutations)
B. In-frame insertions/deletions
C. Missense muttations
D. Silent mutations

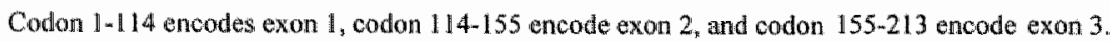


Table 43 Tumor parameters for patients with a clear-cell tumor, also stratiffed by WHL mutation status.

\begin{tabular}{|c|c|c|c|c|c|c|c|c|}
\hline & \multicolumn{2}{|c|}{$\begin{array}{l}\text { All tumors } \\
(N=188)\end{array}$} & \multicolumn{2}{|c|}{$\begin{array}{l}\text { VHL mutated } \\
\text { tumors }(\mathrm{N}=115)\end{array}$} & \multicolumn{2}{|c|}{$\begin{array}{l}\text { Wildtype tumors } \\
(\mathrm{N}=73)\end{array}$} & \multirow[b]{2}{*}{$x^{2}$} & \multirow[b]{2}{*}{$p$ value } \\
\hline & $N$ & $\%$ & $\mathbb{N}$ & $\%$ & $\mathrm{~N}$ & $\%$ & & \\
\hline \multicolumn{9}{|c|}{$T\left(\mathrm{TNM}^{\mathrm{a}}\right)$} \\
\hline 1 & 5 & 2.7 & 4 & 3.5 & 1 & 1.4 & & \\
\hline 2 & 93 & 49.5 & 55 & 47.8 & 38 & 52. & & \\
\hline $3 \mathrm{~A}$ & 35 & 18.6 & 20 & 17,4 & 15 & 20.6 & & \\
\hline $3 \mathbb{B}$ & 50 & 26.6 & 34 & 29.6 & 16 & 21.9 & & \\
\hline 4 & 2 & $1 . \mathbb{1}$ & 1 & 0.9 & 1 & 1.4 & $0.18^{d, f}$ & 0.67 \\
\hline $\mathrm{x}$ & 3 & 1.6 & 1 & 0.9 & 2 & 2.7 & & \\
\hline \multicolumn{9}{|c|}{$N\left(\mathrm{TNM}^{\mathrm{a}}\right)$} \\
\hline 0 & 126 & 67.0 & 78 & 67.8 & 48 & 65.8 & & \\
\hline 1 & $\pi$ & 3.7 & 6 & 5.2 & 1 & 1.4 & & \\
\hline 2 & 7 & 3.7 & 5 & 4.4 & 2 & 2.7 & $1.51^{0,8}$ & 0.22 \\
\hline$x$ & 48 & 25.5 & 26 & 22.6 & 22 & 30.1 & & \\
\hline \multicolumn{9}{|c|}{$\mathrm{M}\left(\mathrm{TNM}^{\mathrm{s}}\right)$} \\
\hline 0 & 131 & 69.7 & 77 & 67.0 & 54 & 74.0 & & \\
\hline $\mathbb{1}$ & 26 & 13.8 & 18 & 15.7 & 8 & 11.0 & $0.99^{\mathrm{f}}$ & 0.32 \\
\hline$x$ & 31 & 16.5 & 20 & 17.4 & 11 & 15.1 & & \\
\hline \multicolumn{9}{|c|}{ Stage $\left(T_{N M}^{\mathrm{a}}\right)$} \\
\hline 1 & 5 & 2.7 & 4 & 3.5 & 1 & 1.4 & & \\
\hline 2 & 83 & 44.2 & 46 & 40.0 & 37 & 50.7 & & \\
\hline 3 & 66 & 35.1 & 42 & 36,5 & 24 & 32.9 & & \\
\hline 4 & 32 & 17.0 & 22 & 19.1 & 10 & 13.7 & $1.41^{\mathrm{d}_{\mathrm{n}} \mathrm{f}}$ & 0.24 \\
\hline$x$ & 2 & 1.1 & 1 & 0.9 & 1 & 1.4 & & \\
\hline \multicolumn{9}{|c|}{ Nuclear grading ${ }^{b, c}$} \\
\hline I & 46 & 24.5 & 27 & 23.5 & 19 & 26.0 & & \\
\hline II & 67 & 35.6 & 43 & 37.4 & 24 & 32.9 & & \\
\hline III & 48 & 25.5 & 29 & 25.2 & 19 & 26.0 & & \\
\hline IV & 27 & 14.4 & 16 & 13.9 & 11 & 15.1 & 0.43 & 0.94 \\
\hline
\end{tabular}

a Based on pathological TNM unless unknown, then clinical TNM (UICC, 1987) was used": "Based on the

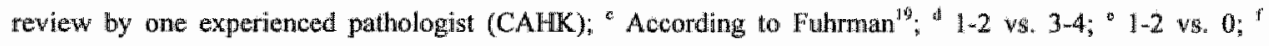
Excludes "X (unknown)" category.

\section{Discussion}

The VHL gene is a tumor suppressor gene predisposing to both sporadic clear-cell (conventional) RCC and von Hippel-Lindau disease. We analyzed 235 cases of primary sporadic RCC, of which 187 cases presented with the histological subtype clear-cell RCC, identified within the Netherlands cohort study on diet and cancer. VHL mutations were assessed by PCR-SSCP, followed by direct sequencing when aberrant signals. 
were detected in SSCP. Screening by SSCP was considered appropriate, since we never detected a mutation by direct sequencing after a negative result on the SSCP in a pilot study. Furthermore, we estimated the upper $95 \%$ confidence limit for cases missed at $3.7 \%$ or $16.9 \%$, based on the individual analyses $(\mathrm{N}-97)$ or on the number of cases $(\mathrm{N}=20)$. Therefore, mutated cases may have been overlooked, which placed them in the wildtype group. This would have resulted in a reduction of contrast between wildtype and mutated groups.

We observed 131 mutations in 114 out of 187 patients (61\%) in patients with clear-cell tumors. Estimates reported. in the literature ${ }^{2,20-30}$ range from $36 \% \%^{25}$ to $54 \%$, and therefore our estimate appears high. However, our estimate is close to the estimate of $75 \%$ as discussed in the review by Cohen ${ }^{8}$. This difference in the observed proportion of mutations in the $V H L$ gene may be attributed to the use of different techniques, e.g., SSCP vs. direct sequencing, to contamination with normal tissue components, or to the type of material analyzed (fresh or archival paraffin material). In our study, we used SSCP followed by direct sequencing, as most investigations did $^{220-29}$. To avoid ignoring VHL mutations through contamination with normal tissue, samples needed to contain at least $10 \%$ tumor cells. The wast majority of samples (180 out of 190) contained at least $50 \%$ viable tumor tissue. The sample with the lowest percentage of viable tumor tissue, in which we observed a mutation, contained $30 \%$ of viable tumor tissue. For 2 samples the percentage of viable tumor tissue was lower $(10 \%$ and $20 \%)$, thus we cannot formally exclude the possibility that we overlooked an existing mutation. We jdentified cases in a population-based study after 11.3 years of followup, the time span and the number of patients and hospitals involved excluded the possibility to collect fresh material. Three other studies on sporadic RCC used paraffin embedded material and the percentages of mutations detected were $46 \% \%^{29}, 50 \%{ }^{22}$ and $54 \% \%^{27}$

The occurrence of various types of mutations is comparable to other studies of this size $\mathrm{e}^{21,24,26,27}$, but some differences are also apparent. The presence of silent mutations is not commonly reported; only $\mathrm{Ma}$ et $\mathrm{al}^{27}$ reported $13 \%$ of silent mutations, similar to $11 \%$ observed by us. It is possible that others do not report silent mutations because the investigators do not wish to designate these as true mutations since their relevance is unclear. The percentage of frameshift mutations was approximately $50 \%$ in most studies $^{21,26}$, comparable to the $48 \%$ observed in the current study. The percentage of inframe deletions/insertions was higher in our study $(12 \%)$ as compared to the percentage in other studies $(<5 \%)^{21,26}$. Compared to the distribution of mutation data present in the Universal $V H L$ Mutation database with 747 mutations $^{31}$, the relative amount of point mutations is much higher in the database $(64 \%)$, compared to the percentage of point mutations we observed ( $44 \%$ ), as well as the frequency of nonsense mutations (11\% vs. $3 \%$ ). However, many of the mutations in the Mutation database concern germline mutations identified in VHL-families. It has been suggested that the mutational spectrum between germline and sporadic $V H L$ mutations may differ ${ }^{25}$, which could explain the disparity. We were not able to select records for sporadic tumors in the 
database, but Gallou et al $^{26}$ described mutations for 145 sporadic cases from this database. Compared to our results, the percentage of nonsense mutations was higher $(8 \%$ vs. $3 \%$ ) and the percentage of in-frame deletions or insertions was lower ( $4 \%$ vs. $12 \%)^{26}$.

Furthermore, we searched the Universal VHL Mutation database ${ }^{31}$ for the mutations observed in the cases with a positive family history of RCC. The $\mathrm{P}$ A (silent) mutation at codon 139 (sample id 1003) was not reported before, the deletion of 1 nucleotide at codon 146 (sample id 306) was recorded in the database twice, while the second 1 nucleotide deletion at codon 167 (sample id 1600) had not been reported before.

For $10 \mathrm{RCC}$ cases, we observed different VHL genotypes in different tumor samples obtained from one tumor. Samples were re-analyzed to exclude technical errors. Again, different $V H L$ genotypes, identical to the earlier genotypes, were observed, showing that tumor heterogeneity appears to play a role. This was an unexpected finding in view of the general acceptance that a mutation in the $V H L$ gene is an early event in clear-cell $\mathrm{RCC}$ carcinogenesis, because one would then expect monogenetic VHL expression. Nevertheless, it is possible that genetic instability leads to additional mutational events, eventually leading to different $V H L$ genotypes in clear-cell RCC. This was underscored by 13 cases showing 2 mutations within the same paraffin block and other studies have also reported multiple mutations per primary tumor ${ }^{21,27,29}$.

The distribution of histological subtypes was comparable to the distribution described before ${ }^{32, \mathrm{p}^{2692}}$. Surprisingly, we also found $V H L$ mutations in some of the non-clear-cell RCC samples that were collected. These results are in contrast with the current opinion that $V H L$ mutations are exclusively restricted to clear-cell RCC. $V H L$ mutations, however, have also been reported in chromophobe $\mathrm{RCC}$, although these were clustered in the $5^{\prime} U T R /$ promoter region ${ }^{22}$, and Brauch et al ${ }^{12}$ described a renal oncocytoma with a $V H L$ mutation. To our knowledge, others have not yet described $V H L$ mutations in papillary RCC. It is conceivable that genetic instability following tumor-initiating events leads to $V H L$ mutations acquired at a later stage of tumor development. As expected, the relative occurrence of $V H L$ mutations in the non-clear-cell $\mathrm{RCC}$ renal tumors was much lower than in clear-cell RCC, emphasizing the crucial role of $V H L$ mutations in clear-cell RCC carcinogenesis.

The high percentage of mutations observed, the observation of mutational heterogeneity (different genotypes in 1 or different samples from the same tumor), and the observation of mutations in other histological types, raises the question whether paraffin material is suitable for analysis. It has been shown, however, that $V H L$ gene mutations can be detected in archival paraffin material ${ }^{33}$. Identical mutations were observed in exon 2 in 3 cases for which archival paraffin material and tumor derived cell lines were assessed by SSCP and sequencing ${ }^{33}$. On the other hand, it has also been reported that artifacts may occur when archival paraffin material is used ${ }^{34}$. Williams et al. reported up to 1 mutation artifact per 500 bases recorded. The chance of such artificial mutations in formalin-fixed material was inversely correlated with the number of cells used in the PCR: the fewer the cells, the more artifacts. No artifacts were 
observed when 300 cells were used and only 1 artifact was observed in 150 cells $(0.03 \%)$. The highest frequency of artifacts was observed when using 10 or 20 cells, and equalled $0.2 \%{ }^{34}$. The number of cells in our analyses, however, was large $(>500$ cells), since 520 - $\mu \mathrm{m}$ slices of paraffin embedded material were used and biopsies were excluded:

The mean turnor size was larger for mutated tumors than for wildtype tumors, however this was not statistically significant. Two other studies did not show a difference in tumor size ${ }^{24,28}$. VHL gene mutations leading to reduced or inactive VHL protein (pVHL) could theoretically lead to a larger tumor size. In the absence of pVHL, hypoxia inducible factor becomes stabilized and upregulates a myriad of hypoxiainducible genes, resulting in hypervascular tumors ${ }^{35}$. This should be a growth advantage. Our results and results from others ${ }^{24,28}$ showed no association with nuclear grade (according to Fuhrman) ${ }^{19}$. It was difficult to compare TNM and stage, since different classifications were used in different studies and the TNM classification has changed definitions in recent years. We reviewed all cases and classified them according to the 1987 version of the TNM classification ${ }^{17}$. We did not observe a difference in $T, N, M$, or stage between mutated and wildtype tumors, as was confirmed by 2 other studies ${ }^{24,28}$. One study, however, reported a higher percentage of mutations in $\mathrm{pT} 3$ tumors with a VHL mutation or hypermethylation, compared to tumors without $V H L$ alteration $(64 \% \text { vs. } 40 \%)^{21}$.

Phenotype should also be considered. Mutations may impair $\mathrm{pVHL}$ function. However, in order for $\mathrm{pVHL}$ to lose its function, biallelic $V H L$ defects have to occur. We did not measure $\mathrm{LOH}$, since it is well documented that LOH commonly oceurs in RCC cases, with estimates ranging from $74 \%{ }^{30}$ to $93 \%{ }^{21}$. Kondo et al. showed $97 \% \mathrm{LOH}$ in mutated or hypermethylated samples compared to $81 \% \mathrm{LOH}$ in wildtype samples ${ }^{24}$. Furthermore, silent mutations do not lead to an altered protein, but these types of mutations were not common (13/131) in our study. Also, pVHL formation may be inhibited by epigenetic silencing, which has been reported to occur in $19 \%$ of clear-cell RCC. This could have resulted in misclassification in comparing pathological parameters, because samples with epigenetic silencing only were classified as wildtype tumors, as we were not able to investigate epigenetic silencing in the current study. Finally, cells in cell culture have been shown to produce two types of proteins: pVHL30 and pVHL19 (a results of internal translation from the second methionine within the $W H L$ open reading frame (Met 54$)^{36-38}$. The pVHL19 product has been shown to inhibit the production of hypoxia-inducible genes, but does not bind to fibronectin ${ }^{36,37}$. Reintroduction of pVHL19 has been shown to inhibit tumor formation in nude mice ${ }^{37}$. We detected mutations $5^{x}$ of codon 54 in 11 cases; these are unusual and would be predicted to affect pVHL30, but not pVHL19 translation products. However in 5 of these 11 cases, a second mutation was observed 3 'of codon 54 . So, in 5 of these cases the other mutation may be relevant. For the other 6 cases, these mutations may not lead to a functionally inactive protein, and thus we may have 
misclassified these. However, as remarked before, the pVHL 19 variant does not bind to fibronectin and thus may not contribute to the maintenance of the extracellular matrix.

\section{Conclusions}

$V H L$ mutations were observed in $61 \%$ of sporadic clear-cell RCC. No differences were observed in nuclear grade, TNM distribution or stage between $V H L$ mutated and wildtype clear-cell RCC. However, the tumor size was larger for VHL mutated clearcell RCC. This study forms a good basis to study possible associations between potential risk factors and $V H L$ mutations in clear-cell RCC. Ultimately, this should lead to greater insight in the etiology of clear-cell RCC.

\section{Acknowledgements}

This study was financially supported by the Dutch Kidney Foundation (Grant C99.1863) and the Dutch Cancer Society. We wish to thank Dr. R.A. Goldbohm, Dr. E. Dorant, C.A. de Brouwer, Prof. Dr. Kiemeney, Prof. Dr. Geurts van Kessel and Prof. Dr. Ruiter for their preparatory work for this study; Dr. A. Kester for statistical advice; S. van de Crommert, H. Brants, J. Nelissen, C. de Zwart, M. Moll, W. van Dijk, M. Jansen and A. Pisters for assistance; and H. van Montfort, T. van Moergastel, L. van den Bosch and R. Schmeitz for programming assistance. The authors also thank the staffs of the Dutch regional cancer registries and the Netherlands national database for pathology (PALGA) for providing incidence data. Finally, we would like to thank the pathology laboratories from the following hospitals for providing paraffin material: UMC Nijmegen, Academisch Ziekenhuis Groningen, Leids Universitair Medisch Centrum (LUMC), Rijnland ziekenhuis, Antoni van Leeuwenhoek ziekenhuis, Laboratorium Pathologie Oost Nederland, Academisch Ziekenhuis Utrecht, Ziekenhuis Rijinstate, Laboratorium voor de Volksgezondheid in Friesland, Stichting samenwerkende ziekenhuizen Oost-Groningen, Martini ziekenhuis, Stichting Samenwerking Delftse Ziekenhuizen, Ziekenhuis Leyenburg, Vrije Universiteit Medisch Centrum, Academisch Medisch Centrum, Academisch Ziekenhuis Maastricht, Groene Hart Ziekenhuis, Canisius Wilhelmina Ziekenhuis, Slotervaartziekenhuis, Maaslandziekenhuis, Atrium Medisch Centrum Heerlen, Atrium Medisch Centrum Kerkrade, Deventer ziekenhuis, IJsselmeerziekenhuizen Lelystad, Isala klinieken, Elkerliekziekenhuis, Jeroen Bosch Ziekenhuis, Pathologisch laboratorium voor het Gooi en Almere, Regional Pathologisch \& Cytologisch Laboratorium voor Eemland en Noord/West Veluwe, Diakonessenhuï Utrecht, St. Antonius Ziekenhuis, Onze Lieve Vrouwe Gasthuis, Boven-IJ Ziekenhuis, Stichting Pathologisch Anatomisch Laboratorium Kennemerland, Ziekenhuis de Heel, Diaconessenhuis Leiden, Rode Kruis Ziekenhuiis, Bronovo ziekenhuis, Laurentius ziekenhuis Roermond, Pathologisch 
Laboratorium voor Dordrecht en omstreken, Zuiderziekenhuis, St. Claraziekenhuis, Medisch Centrum Haaglanden, Havenziekenhuis, Stichting Streek Laboratorium Zeeland, Stichting Pathologisch en cytologisch laboratorium West-Brabant, Stichting lgnatius ziekenhuis, St. Elisabeth ziekenliwis, Catharinaziekenhuis, St. Maartensgasthuis and Spaane ziekenhuis. 


\section{Additional file 1}

\section{Calculation of the estimated ipper $95 \%$ confidence limit}

The point estimate for the percentage of samples negative on the SSCP and positive on direct sequencing equals $0 \%$ (Table 4.2 ); the upper confidence limit was calculated by the following formula: $P(X=0 \mid N, P u)=0.025 \rightarrow(1-P u)^{N}=0.025$. This analysis was performed for two situations. Situation 1; calculation of upper $95 \%$ confidence limit based on the cases and situation 2; calculation of upper $95 \%$ confidence limit based on the individual analyses. The $\mathrm{N}$ differs for these situations described; for situation $1, \mathrm{~N}$ equals 20 (there are 20 cases for with at least one negative SSCP, followed by a negative result on direct sequencing), for situation $2 \mathrm{~N}$ equals 97 (of all $120 \mathrm{SSCP}$ results, 97 were negative and were followed by a negative result on direct sequencing). The estimations of the upper confidence limit are: based on situation 1: $P(x=0 \mid N=20$, $\mathrm{P}=\mathrm{Pu})=0.025 \rightarrow(1-\mathrm{Pu})^{20}=0.025 \rightarrow \mathrm{Pu}=0.1685$ and based on situation 2: $\mathrm{P}(\mathrm{x}=0 \mid \mathrm{N}=97$, $\mathrm{P}=\mathrm{Pu})=0.025 \rightarrow(1-\mathrm{Pu})^{97}=0.025 \rightarrow \mathrm{Pu}=0.0373$. However, both of these estimates are not completely true, because in the first situation we assume all the analyses on all primer sets to be dependent and for the second estimation, we assume all the analyses of all primer sets to be completely independent, neither of which is true. Primer sets are not completely independent, since some primer sets were selected to overlap to sequence the whole coding sequence of the gene. In total, 204 out of 1042 nucleotides were determined by more than 1 primer set. Also, the quality of the extracted DNA and other properties of the DNA may render the analyses by different primer sets not independent. 


\section{Additional file 2}

Description of observed mutations $(\mathrm{N}=139)$, histological parameters and personal characteristics for 121 cases.

\begin{tabular}{|c|c|c|c|c|c|c|c|c|c|}
\hline \multirow{2}{*}{ Sample } & \multirow{2}{*}{$\begin{array}{l}\text { Ser/ Age at } \\
\text { incidence }\end{array}$} & \multicolumn{3}{|c|}{$\begin{array}{c}\text { DMM } \\
\text { classification }\end{array}$} & \multirow{2}{*}{ Stage } & \multirow[t]{2}{*}{ Histollogy } & \multirow[t]{2}{*}{$\begin{array}{l}\text { Nuelear } \\
\text { Gradde }\end{array}$} & \multirow[t]{2}{*}{$\begin{array}{l}\text { \% Vital } \\
\text { tumor tissue }\end{array}$} & \multirow[t]{2}{*}{$\begin{array}{l}V M L \text { status } \\
\text { Mutation }\end{array}$} \\
\hline & & $\mathrm{T}$ & $\mathrm{N}$ & $M$ & & & & & \\
\hline 941 & $M / 7$ & 2 & 0 & 0 & II & Clear-cell & I & 75 & $\begin{array}{l}{[\mathrm{c} .1-1,20 \mathrm{del} 21(+)} \\
\text { c.291_310del20] }\end{array}$ \\
\hline 349 & F/68 & 2 & 0 & 0 & II & Clear-cell & mil & 50 & $c .102 \mathrm{C}>\mathrm{T}$ \\
\hline 2,048 & $M / 65$ & $3 \mathrm{~B}$ & 0 & 0 & III & Clear-cell & IV & 85 & $0.113 \mathrm{C}>\mathrm{T}$ \\
\hline 1,782 & $M / 66$ & 38 & 2 & $\mathrm{X}$ & IV & Clear-cell & IIII & 90 & $\begin{array}{l}{[c .115 \mathrm{G}>\mathrm{A}(+)} \\
\mathrm{c} 291 \mathrm{C}>\mathrm{A}]\end{array}$ \\
\hline 1,716 & $F / 58$ & 2 & $\mathrm{x}$ & $x$ & 11 & Clear-cell & II & 50 & $\begin{array}{l}{[\mathrm{c} .118 \mathrm{C}>\mathrm{T}(+)} \\
\text { c. } 145 \mathrm{G}>\mathrm{T}]\end{array}$ \\
\hline 973 & $M / 61$ & $3 \mathrm{~B}$ & 0 & 0 & III & Clear-cell & III & 60 & {$[c .122 \mathrm{~A}>\mathrm{T}(+)$} \\
\hline 974 & & & & & & & III & 90 & $c .1830 \mathrm{CT}]$ \\
\hline 1,013 & $\mathrm{~F} / 70$ & 2 & 1 & 1 & IV & Clear-cell & III & 100 & $0.125 \mathrm{~A}>\mathrm{T}$ \\
\hline 187 & $M / 74$ & $3 \mathrm{~B}$ & 0 & 0 & m & Clear-cell & II & 100 & c. $142 \mathrm{C}>\mathrm{G}$ \\
\hline 336 & $M / 65$ & 2 & 0 & 0 & II & Clear-cell & II & 90 & $\begin{array}{l}{[c .149 \mathrm{C}>\mathrm{G}(+)} \\
\text { c. } 221 \mathrm{P}>\mathrm{C}]\end{array}$ \\
\hline 1,524 & $M / 64$ & 2 & 0 & $\mathrm{X}$ & II & Clear-cell & II & 100 & {$[\mathrm{c} .151 \mathrm{G}>\mathrm{C}(+)$} \\
\hline 1,525 & & & & & & & II & 100 & c. $284 \mathrm{C}>\mathrm{GI}$ \\
\hline 463 & $F / 66$ & $3 \mathrm{~B}$ & 0 & 0 & III & Clear-cell & III & 100 & c. 158 ins 45 \\
\hline 1,510 & $\mathrm{~F} / 68$ & 2 & 0 & 0 & II & Clear-cell & I & 100 & c.166dell \\
\hline 2,109 & $F / 65$ & 2 & 0 & 0 & II & Clear-cell & I & 100 & $\begin{array}{l}{[\mathrm{c} .183 \mathrm{del}(\mathrm{A}]} \\
\text { c. } 463+5 \mathrm{~T}>\mathrm{A}]\end{array}$ \\
\hline 191 & E $/ 66$ & 2 & 0 & 0 & $\mathbb{1 1}$ & Clear-cell & 1 & 90 & c.183_187dels \\
\hline 683 & $M / 74$ & $3 \mathrm{~A}$ & 0 & 0 & IIII & Clear-cell & II & 100 & c. 183 _187del5 \\
\hline 1,306 & $M / 62$ & $3 \mathrm{~A}$ & 0 & 0 & III & Clear-well & III & 100 & c. $183 \mathrm{C}>\mathrm{P}$ \\
\hline 260 & $M / 69$ & 2 & 0 & 0 & II & Clear-cell & $\mathbb{1}$ & 100 & c.183ins5 \\
\hline 14 & $M / 66$ & 2 & 0 & 0 & II & Clear-cell & 11 & 100 & c. 185 ins 5 \\
\hline 669 & $M / 65$ & $3 \mathrm{~B}$ & 0 & 0 & III & Clea-cell & IV & 70 & c. $1950>C$ \\
\hline 829 & $M / 66$ & $3 \mathrm{~A}$ & 0 & 0 & IIII & Clear-cell & III & 60 & c. $198.221 \mathrm{del} 24$ \\
\hline 592 & $M / 73$ & 2 & 0 & 0 & II & Clear-cell & III & 100 & $\begin{array}{l}{[c .202 T>A(+)} \\
\text { c. } 203 C>A]\end{array}$ \\
\hline 1.809 & $F / 65$ & 2 & 0 & 0 & II & Clear-cell & II & 90 & $\begin{array}{l}{[0.204 \text { dell }(+)} \\
c .283 \text { 297del15] }\end{array}$ \\
\hline 2,002 & $10 / 65$ & $3 \mathrm{~B}$ & 0 & 0 & III & Clear-cell & III & 90 & c.205del1 \\
\hline 757 & $M / 67$ & $3 B$ & $\Downarrow$ & $\mathrm{x}$ & III & Clear-cell & I & 95 & c.208G $\mathrm{T}$ \\
\hline 2,043 & $M / 70$ & $3 \mathrm{~A}$ & 0 & 0 & III & Clear-cell & III & 70 & c $21522590 \mathrm{de} 145$ \\
\hline 2,438 & $M / 77$ & $3 B$ & 0 & 1 & IV & Clear-cell & II & 50 & c. $217 \mathrm{dell}$ \\
\hline 2,035 & $M / 72$ & 2 & 0 & 1 & IV & Clear-cell & 1 & 90 & $c .219 \mathrm{G}>\mathrm{A}$ \\
\hline 2,049 & $M / 68$ & $3 \mathrm{~A}$ & $x$ & $\mathrm{x}$ & III & Clear-cell & IV & 90 & $0.221 \mathrm{~T}>\mathrm{A}$ \\
\hline 597 & $F(7)$ & 2 & 0 & 0 & II & Clear-cell & 1 & 95 & $0.227 \mathrm{dell}$ \\
\hline
\end{tabular}




\begin{tabular}{|c|c|c|c|c|c|c|c|c|c|}
\hline \multirow[t]{2}{*}{ Sample } & \multirow[t]{2}{*}{$\begin{array}{l}\text { Sex/Age at } \\
\text { incidence }\end{array}$} & \multicolumn{3}{|c|}{$\begin{array}{c}\text { TNM } \\
\text { classification }^{\text {n }}\end{array}$} & \multirow[t]{2}{*}{ Stage $^{3}$} & \multirow[t]{2}{*}{ Histology } & \multirow[t]{2}{*}{$\begin{array}{l}\text { Nuclear } \\
\text { Grade }^{b_{2}}\end{array}$} & \multirow[t]{2}{*}{$\begin{array}{c}\text { \% Vital } \\
\text { tumor tissue }\end{array}$} & \multirow[t]{2}{*}{$\begin{array}{l}\text { WHL status } \\
\text { Mutution }\end{array}$} \\
\hline & & $\mathbb{T}$ & $\mathrm{N}$ & M & & & & & \\
\hline 1,323 & $\mathbb{M} / 58$ & 4 & $\mathrm{X}$ & 1 & IV & Clear-cell & IV & 100 & $0: 231 \_232$ del 2 \\
\hline 593 & $M / 70$ & 2 & 0 & 0 & II & Clear-cell & II & 95 & $0.231 \mathrm{C}>\mathrm{A}$ \\
\hline 334 & $M / 70$ & $3 B$ & $x$ & 0 & IIII & Clear-cell & IIII & 80 & c. 234237 del4 \\
\hline 562 & $M / 65$ & $3 \mathrm{~B}$ & 0 & 0 & IIII & Clear-cell & II & 100 & c.236_237del2 \\
\hline 1,798 & $M / 67$ & 2 & $\mathrm{x}$ & $X$ & $\mathbb{I I}$ & Clear-cell & III & 95 & c. $239241 \mathrm{del} 3$ \\
\hline 926 & $M / 73$ & $3 B$ & 1 & 0 & III & Clear-cell & II & 70 & $\mathrm{c} .240 \mathrm{r}>\mathrm{A}$ \\
\hline 949 & $M / 60$ & $3 \mathrm{~B}$ & 2 & $x$ & IV & Clear-cell & III & 50 & $0.241 \mathrm{C}>\mathrm{T}$ \\
\hline 879 & $\mathrm{M} / 70$ & 2 & 0 & $x$ & II & Clear-cell & III & 48 & c. 253 ins 23 \\
\hline 1,502 & $M / 65$ & 2 & 0 & 1 & TV & Clear-cell & III & 100 & c.268_270del3 \\
\hline 1,651 & $\mathrm{~F} / 58$ & 2 & 0 & 0 & II & Clear-cell & III & 100 & c.268_274del 7 \\
\hline 6 & $M / 64$ & 2 & 0 & 0 & II & Clear-cell & n & 100 & c.270 $272 \mathrm{del} 3$ \\
\hline 7 & $M / 64$ & $3 \mathrm{~A}$ & 1 & 1 & IV & Clear-cell & III & 50 & c. $274 \mathrm{G}>\mathrm{T}$ \\
\hline 424 & $F / 69$ & 2 & 0 & $\mathrm{X}$ & II & Clear-cell & 1 & 100 & c.282ins 1 \\
\hline 229 & $M / 75$ & 2 & 0 & 0 & II & Clear-cell & IV & 45 & c.288_291del4 \\
\hline 2,088 & $F / 70$ & 2 & 0 & 0 & II & Clear-cell & II & 67 & c. $288 \mathrm{G}>\mathrm{T}$ \\
\hline 1,339 & $F / 68$ & $3 \mathrm{~B}$ & 0 & 0 & III & Clear-cell & III & 50 & c. $291 \mathrm{C}>\mathrm{T}$ \\
\hline 755 & $M / 67$ & $3 B$ & $X$ & 0 & III & Clear-cell & II & 95 & c. $301 \mathrm{C}>\mathrm{T}$ \\
\hline 1.342 & $F / 74$ & 2 & 0 & 0 & II & Clear-cell & II & 90 & c. 302 304del 3 \\
\hline 176 & $M / 69$ & 38 & $\mathrm{x}$ & $\mathrm{X}$ & III & Clear-cell & 11 & 100 & $\begin{array}{l}\text { [c. } 304 \mathrm{C}>\mathrm{G}(+) \\
\text { c.444del1] }\end{array}$ \\
\hline 695 & F/ 69 & $3 \mathrm{~B}$ & 0 & 0 & III & Clear-cell & II & 90 & $0.306 \quad 308$ del 3 \\
\hline 343 & $F / 60$ & 2 & 0 & 0 & II & Clear-cell & III & 70 & $0.314 \mathrm{C}>\mathrm{T}$ \\
\hline 954 & $\mathrm{M} / 70$ & $3 \mathrm{~A}$ & $x$ & $x$ & III & Clear-cell & IV & 100 & $\begin{array}{l}{\left[\mathrm{c} .321 \_323 \mathrm{del} 3(+)\right.} \\
\mathrm{c} .426 \mathrm{~T}>\mathrm{G}]\end{array}$ \\
\hline 161 & $M / 69$ & 2 & 0 & 0 & II & Clear-cell & I & 66 & c. $324 \mathrm{C}>\mathrm{A}$ \\
\hline 1,350 & $\mathrm{~F} / 65$ & 1 & 0 & 0 & 1 & Clear-cell & 1 & 85 & c.324del II \\
\hline 965 & $M / 67$ & $3 B$ & $\mathrm{X}$ & $x$ & III & Clear-cell & 1 & 90 & c. $328,333 \mathrm{del} 6$ \\
\hline 49 & $F / 66$ & $3 B$ & $\mathrm{x}$ & 1 & IV & Clear-cell & $\|$ & 90 & $\begin{array}{l}{[\mathrm{c} .330 \mathrm{de} \|(\mathrm{H})} \\
\text { c.381dell] }\end{array}$ \\
\hline 307 & $M / 63$ & 2 & $x$ & $\mathrm{x}$ & II & Clear-cell & II & 95 & c.33ldell \\
\hline 48 & $M / 63$ & $3 \mathrm{~B}$ & 0 & 0 & IIII & Clear-cell & IV & 100 & c. $333 \mathrm{dell}$ \\
\hline 189 & $M / 58$ & $3 B$ & 0 & 0 & III & Clear-cell & IIII & 95 & c. $334 \mathrm{~T}>\mathrm{O}$ \\
\hline 1.912 & $M / 66$ & $3 \mathrm{~A}$ & 0 & 0 & liII & Clear-coll & nil & 100 & $\cos 39 \mathrm{~A}>\mathrm{T}$ \\
\hline 904 & $F / 65$ & 2 & 1 & 0 & IIf & Clear-cell & II & 100 & $c .340 G \% \mathrm{~T}$ \\
\hline 38 & $F / 66$ & $3 \mathrm{~A}$ & 0 & 0 & III] & Clear-cell & II & 100 & $\begin{array}{l}\text { [c. } 340 \mathrm{G}>\mathrm{A}(+) \\
\text { c. } 340+2 \mathrm{~T}>\mathrm{G} \rrbracket\end{array}$ \\
\hline 2,458 & $F / 57$ & $3 \mathrm{~A}$ & $\mathrm{X}$ & 0 & III & Clear-cell & 1 & 85 & c. $340+9 \mathrm{C}>\mathrm{T}$ \\
\hline 262 & $F / 64$ & 2 & 0 & 0 & II & Clear-cell & 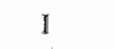 & 90 & c. $341-2 \mathrm{dell}$ \\
\hline 690 & F/75 & 3B & $\mathrm{x}$ & 1 & IV & Clear-cell & in & 60 & c.341-1_367del28 \\
\hline 1,299 & $M / 72$ & 2 & 0 & 0 & 11 & Clear-cell & II & 90 & c. $343 \mathrm{C}>\mathrm{A}$ \\
\hline 596 & F/ 66 & 2 & 0 & 0 & II & Clear-cell & III & $\mathbb{1 0 0}$ & c. 348 354del? \\
\hline 338 & $M / 68$ & $3 \mathrm{~B}$ & 0 & 0 & III & Clear-cell! & III & 100 & c. $353 \mathrm{~T}>\mathrm{A}$ \\
\hline
\end{tabular}




\begin{tabular}{|c|c|c|c|c|c|c|c|c|c|}
\hline \multirow[t]{2}{*}{ Sample } & \multirow[t]{2}{*}{$\begin{array}{l}\text { Sex/Age at } \\
\text { incidence }\end{array}$} & \multicolumn{3}{|c|}{$\begin{array}{c}\text { TMWM } \\
\text { classification }\end{array}$} & \multirow[t]{2}{*}{ Stage } & \multirow[t]{2}{*}{ Histology } & \multirow[t]{2}{*}{$\begin{array}{l}\text { Nivclear } \\
\text { Graide }^{\text {bac }}\end{array}$} & \multirow{2}{*}{$\begin{array}{c}\% \text { Vital } \\
\text { tumor tisstue }\end{array}$} & \multirow{2}{*}{$\begin{array}{l}\text { WHL status } \\
\text { Mutation }\end{array}$} \\
\hline & & $T$ & $\mathbb{N}$ & $M$ & & & & & \\
\hline 9 & $M / 70$ & $3 A$ & $\mathrm{X}$ & 1 & IV & Clear-cell & IV & 100 & c. 373,378 del 6 \\
\hline 400 & $\mathrm{p} / 7 \mathrm{~s}$ & 2 & 0 & $\mathrm{X}$ & il & Clear-cell & II & 90 & $c_{n} 383 T>A$ \\
\hline 2,057 & $\mathrm{M} / 68$ & 2 & $x$ & $\mathrm{x}$ & $\mathbb{1 I}$ & Clear-cell & IV & 50 & c.390dell \\
\hline 2,454 & $F / 66$ & 2 & 0 & 1 & $\mathbb{N}$ & Clear-cell & II & 95 & c.391A $>\mathrm{T}$ \\
\hline 1,167 & $M / 74$ & 1 & 0 & 0 & i & Clear-cell & 1 & 30 & c.393_396del4 \\
\hline 2,446 & $M / 72$ & $3 B$ & 1 & $x$ & III & Clearucell & III & 85 & c. 393 3966del4 \\
\hline 559 & $\mathrm{M} / 67$ & $3 \mathrm{~A}$ & 0 & 0 & III & Cleatroell & 1 & 100 & c. $406 \quad 408 \mathrm{del} 3$ \\
\hline 854 & $M / 65$ & $3 \mathrm{~A}$ & 0 & $a$ & III & Clear-cell & III & 70 & c.406ins: \\
\hline 2,078 & $M / 7 \mathbb{1}$ & $3 A$ & 0 & 1 & IV & Clear-cell & III & 80 & c.408dell \\
\hline 777 & $M / 67$ & $3 \mathrm{~B}$ & 0 & 0 & $\mathrm{III}$ & Clear-celi. & II & 100 & c. $408 \mathrm{~T}-\mathrm{G}$ \\
\hline 309 & $M / 63$ & $3 \mathrm{~A}$ & 0 & $x$ & III & Clear-cell & 1 & 100 & c. $409 \mathrm{del}$ \\
\hline 2,449 & $6 / 75$ & 2 & 0 & 0 & II & Clear-cell & II & 100 & c. 413 4 414 del2 \\
\hline 947 & $M / 80$ & $x$ & 0 & 0 & $x$ & Clear-cell & II & 100 & $c .417 \bar{T}>A$ \\
\hline 1,003 & $F / 70$ & 1 & 0 & 0 & 1 & Clear-cell & l & 60 & $c .417 \mathrm{~T}>\mathrm{A}$ \\
\hline 670 & $M / 77$ & $3 B$ & 2 & 0 & IV & Clear-cell & i & 60 & c.418_425del8 \\
\hline 461 & $F / 65$ & $3 \mathrm{~A}$ & 0 & 0 & III & Chear-cell & I & 100 & c.431dell \\
\hline 306 & $M / 67$ & $3 B$ & 2 & 0 & IV & Clear-cell & IV & 75 & {$[\mathrm{c} .437 \mathrm{dell}(+)$} \\
\hline 1,600 & & & & & & & IV & 75 & c.501del1] \\
\hline 651 & $F / 71$ & $3 \mathrm{~A}$ & $\mathrm{X}$ & $\mathbb{1}$ & IV & Clear-cell & IV & 70 & c. 457 _ $463 \mathrm{del} 7$ \\
\hline 1,334 & $\mathrm{~F} / 75$ & 2 & 0 & 1 & IV & Clear-cell & II & 100 & c.458ins 4 \\
\hline 952 & $M / 72$ & 2 & 0 & 1 & IV & Clear-cell & IV & 100 & c. 462 ins 1 \\
\hline 398 & $5 / 70$ & 2 & $\mathrm{X}$ & 0 & II & Clear-cell & IV & 100 & $c_{n} 463+3 A>T$ \\
\hline 2,092 & $\mathrm{~F} / 62$ & $3 \mathrm{~B}$ & 2 & 1 & IV & Clear-cell & IV & 80 & c. $463+8 \mathrm{C}>\mathrm{T}$ \\
\hline 989 & $M / 66$ & 2 & 0 & 0 & II & Clear-cell & 1 & 90 & c. $463+23 \mathrm{~A}>\mathrm{G}$ \\
\hline 1,325 & $M / 69$ & 2 & $\mathrm{x}$ & 0 & III & Clear-cell & I & 85 & c. $464-2$ 469del 8 \\
\hline 2,455 & $M / 71$ & 2 & 0 & 0 & II & Clear-cell & II & 70 & $c .464-10>A$ \\
\hline 11,332 & $M / 66$ & 2 & 0 & $x$ & II & Clear-cell & II & 90 & c. $464-16>C$ \\
\hline 1,303 & $M / 66$ & 2 & 0 & 0 & II & Clear-cell & II & 70 & $c, 472 \mathrm{C}>\mathrm{G}$ \\
\hline \multirow[t]{2}{*}{682} & $M / 75$ & 2 & $\mathrm{x}$ & 0 & $\|$ & Clear-cell & III & 95 & {$[\mathrm{c} .480 \mathrm{del}(\mathrm{t})$} \\
\hline & & & & & & & & & c. $\left.482 \_483 \mathrm{del} 2\right]$ \\
\hline 170 & $F / 67$ & 2 & 0 & 0 & II & Clear-cell & II & 67 & c.481_483del 3 \\
\hline 692 & $F / 70$ & 2 & $x$ & 0 & III & Clear-cell & 1 & 85 & $c .481 \mathrm{C}>\mathrm{T}$ \\
\hline 2,127 & $15 / 74$ & $3 \mathrm{~B}$ & 0 & $x$ & III & Clear-cell & IV & 90 & c. 482 ins 1 \\
\hline 960 & $M / 60$ & 2 & 0 & 0 & II & Clear-cell & II & 90 & $0.487 \mathrm{dell}$ \\
\hline 1,329 & $\mathrm{M} / 73$ & 2 & 0 & 1 & IV & Clear-cell & $n$ & 95 & c. $494 T>A$ \\
\hline 9444 & $M / 69$ & 2 & 0 & 0 & III & Clear-cell & III & 100 & c. $497 \mathrm{~T}>\mathrm{G}$ \\
\hline 568 & F/76 & $3 \mathrm{~A}$ & $\mathrm{x}$ & 0 & III & Clear-cell & 1 & 50 & c.523 deli \\
\hline 1,314 & $M / 66$ & $3 \mathrm{~B}$ & 0 & 0 & III & Clear-cell & II & 50 & c.525_532del8 \\
\hline 1,170 & $M / 66$ & 1 & 0 & 0 & 1 & Clear-cell & $\mathrm{n}$ & 80 & c. $.525 \bar{C}>A$ \\
\hline 1,297 & $M / 59$ & $3 \mathrm{~A}$ & $\mathrm{x}$ & 1 & IV & Clear-cell & IV & 100 & $0.529 \mathrm{dell}$ \\
\hline 787 & $M / 70$ & $3 \mathrm{~A}$ & 0 & 0 & $\mathrm{mII}$ & Clear-cell & $\mathrm{mII}$ & 50 & c. $529 \mathrm{ins} 1$ \\
\hline 11 & $M / 69$ & 2 & $\mathrm{x}$ & 0 & II & Clear-cell & II & 100 & $0.547 \mathrm{dell}$ \\
\hline
\end{tabular}




\begin{tabular}{|c|c|c|c|c|c|c|c|c|c|}
\hline \multirow[t]{2}{*}{ Sample } & \multirow[t]{2}{*}{$\begin{array}{l}\text { Sex / Age at } \\
\text { incidence }\end{array}$} & \multicolumn{3}{|c|}{$\begin{array}{c}\text { TNM } \\
\text { classification }^{\text {" }}\end{array}$} & \multirow[t]{2}{*}{ Stage $^{a}$} & \multirow[t]{2}{*}{ Histology } & \multirow[t]{2}{*}{$\begin{array}{l}\text { Nuclear } \\
\text { Gradede }^{\text {bie }}\end{array}$} & \multirow[t]{2}{*}{$\begin{array}{c}\text { \% Vital himor } \\
\text { dissue }\end{array}$} & \multirow[t]{2}{*}{$\begin{array}{l}\text { rHL status } \\
\text { Mutation }^{\mathrm{i}}\end{array}$} \\
\hline & & $\mathrm{T}$ & $\mathrm{N}$ & M & & & & & \\
\hline 506 & $F / 76$ & 2 & 0 & 0 & II & Clear-cell & II & 80 & $\begin{array}{l}{[0.559 \text { s60del }(+)} \\
\text { c.563dell] }\end{array}$ \\
\hline 496 & $M / 66$ & $3 B$ & 0 & 0 & III & Clear-cell & 1 & 100 & $\| c .559$ 560del2 $(t)$ \\
\hline 497 & & (2) & & & & & 11 & 100 & $c .561,563$ ide 3$]$ \\
\hline 1,001 & $F / 61$ & 2 & $x$ & $\mathrm{X}$ & II & Clear-cell & III & 100 & $c .561,564 \mathrm{del} 4$ \\
\hline 1 & $M / 60$ & 3B & 0 & 0 & m & Clear-cent & II & 100 & $0.563 \mathrm{~T}>\mathrm{A}$ \\
\hline 369 & $M / 74$ & 2 & $x$ & 1 & IV & Clear-cell & $\Downarrow$ & 80 & $0.566 \_569 \mathrm{del} 4$ \\
\hline 1,004 & $\mathrm{~F} / 69$ & 2 & 0 & 0 & II & Clear-cell & 1 & 100 & c.567dell \\
\hline 2,086 & $F / 74$ & $3 B$ & $\mathrm{x}$ & 0 & III & Clear-cell & II & 100 & c. $573,577 \mathrm{del} 5$ \\
\hline 962 & $M / 74$ & $3 \mathrm{~B}$ & 0 & 0 & III & Chromophobe & IV & 50 & {$[0.1] 17$ dell $7(+)$} \\
\hline 963 & & & & & & & IV & 50 & $\left.c_{4} 47 \| \mathrm{T}>A\right]$ \\
\hline 347 & $M / 67$ & $3 \mathrm{~A}$ & 0 & 0 & III & Chromophobe & II & 40 & $c .333 \mathrm{C}>\mathrm{I}$ \\
\hline 1,016 & $F / 65$ & 2 & $\mathrm{x}$ & $\mathrm{X}$ & II & Oncocytoma & $x$ & 90 & c. $113 \mathrm{C} \gg \mathrm{T}$ \\
\hline 1,499 & M/ 69 & 2 & 0 & 0 & 11 & Papillary & n & 100 & $0.264 \mathrm{C}>\mathrm{C}$ \\
\hline 31 & $M / 63$ & 2 & 0 & $x$ & II & Papillary & III & 100 & $0.443 \mathrm{~T}>\mathrm{C}$ \\
\hline 2,456 & $F / 73$ & 2 & 3 & 0 & IV & Unclassified & IV & 80 & c. $245 \mathrm{G}>\mathrm{C}$ \\
\hline 16 & F/65 & $3 \mathrm{~A}$ & 0 & 0 & III & Unclassified & IV & 90 & c. $353 \mathrm{~T}>\mathrm{C}$ \\
\hline
\end{tabular}

"Based on pathological TNM unless unknown, then clinical TNM (UICC, 1987) was used" "Based on the review by one experienced pathologist (CAHK); "According to Fuhrman ${ }^{19}$; "The notation of WHL gene mutations was based on the guidelines described at the following website: www.genomic.unimelb.edu.au/mdi/mutnomen/examplesDNA.html (Exon 1: c.1 through c.340; exon 2: c.341 through c.463; exon 3: c464 through c. 642 ) 


\section{References}

1. Kovacs $\mathrm{G}$, Akhtar M, Beckwith $\mathrm{BJ}$, et al. The Heidelberg classification of renal cell tumours [editorial]. J Pathol 1997;183:131-3.

2. Gnarra JR, Tory $\mathrm{K}$, Weng $\mathrm{Y}$, et al Mutations of the VHL tumour suppressor gene in renal carcinonia: Nat Genet 1994:7:85-90.

3. Latif $\mathbf{F}$ Tory $\mathrm{K}$, Gnarra $\mathrm{J}$, et al. Identification of the von Hippel-Lindau disease tumor suppressor gene. Science 1993;260:1317-20.

4. Zbar B, Brauch H, Talmadge $C$, Linehan M. Loss of alleles of loci on the short arm of chromosome 3 in renal cell carcinoma. Nature 1987;327:721-4.

5. Gnarra JR, Duan DR, Weng $Y$, ef al. Molecular cloning of the von Hippel-Lindau tumor suppressor gene and its role in tenal carcinoma. Biochm Biophys Acta 1996;1242:201-10.

6. Richards FM. Molecular pathology of von Hippel-Lindau disease and the VHL tumour stuppressor gene. Expert Rev Mol Med 2001;2001:1-27.

7. Kaelin $W G$, Jr. The von hippel-lindau tumor suppressor gene and kidney cancer. Clin Cancer Res 2004;10:6290S-5S.

8. Cohen HT. Advances in the molecular basis of renal neoplasia. Curr Opin Nephrol Hy 1999;8:325-31.

9. Herman $\sqrt{ } G$, Latif F, Weng $Y$, et al. Silencing of the VHL tumor-suppressor gene by DNA methylation in renal carcinoma. Proe Natl Acad Sci U S A 1994;9 19700-4.

10. McLaughlin JK, Lipworth L. Epidemiologic aspects of renal cell cancer. Semin Oncol 2000;27:115-23.

11. Brauch H, Weirich G, Mornauer MA, Storkel S, Wohl T, Bruning T. Trichlloroethylene exposure and specific somatic mutations in patients with renal cell carcinoma. $J$ Nat Cancer Inst 1999;91:854-61.

12. Brauch $\mathbb{H}$, Weirich $G$, Klein $\mathbb{B}$, Rabstein $S$, Bolt $H M$, Buning $T$. VHL mutations in renal cell cancer: does occupational exposure to trichloroethylene make a difference? Toxicol Lett 2004:151:301-10.

13. Hemminki K, Jiang Y, Ma X, Yang $K$, Egevad L, Lindblad P. Molecular epidemiology of VHL gene mutations in renal cell carcinoma patients: relation to dietary and other factors. Carcinogenesis 2002;23:809-15.

14. Shiao $\mathrm{YH}_{3}$ Rice IM, Anderson LM, Diwan BA, Hard GC. von Hippel-Lindau gene mutations in $\mathrm{N}$-nitrosodimethylamine-induced rat renal epithelial tumors [see comments]. I] Natl Cancer Inst 1998;90:1720-3.

15. Van den Brandt PA, Goldbohm RA, Van 't Veer P, Volovics A, Hermus RJ, Sturmans F. A large-scale prospective cohort study on diet and cancer in The Netherlands. $J$ Clin Epidemiol 1990;43:285-95.

16. Van den Brandt PA, Schouten LJ, Goldbohm RA, Dorant E, Hunen PM. Development of a record linkage protocol for use in the Dutch Cancer Registry for Epidemiological Research. lnt J Epidemiol 1990;19:553-8.

117. Hermanek P, Sobin L. TNM Classification of Malignant Tumours. Fourth, fully revised edition ed: Springer-Verlag, 1987.

18. Eble J, Sauter G, Epstein J, Sesterhenn I. World Health Organization Classification of Tumours. Pathology and Genetics. Tumours of the Urinary System and Male Genital Orgains. Lyon: LARC Press, 2004.

19. Fuhrman S, Lasky L, Limas C. Prognostic significance of morphologic parameters in rena] cell carcinoma. Am J Surg Pathol 1982;6:655-63.

20. Bailly $M_{s}$ Bain $C$, Favrot MC, Ozturk M. Somatio mutations of von Hippel-Lindau (VHL) tumor-suppressor gene in European kidney cancers. Int J Cancer 1995;63:660-4. 
21. Brauch $H$, Weirich $G$, Brieger $J$, et al. VHL alterations in human clear cell tenal cell carcinoma: association with advanced tumor stage and a novel hot spot mutation. Cancer Res 2000;60:1942-8.

22. Barnabas $N$, Amin MB, Pindolia $K$, Nalnavati $R$, Worsham MJ. Mutations in the von Hippel-Lindau (VHL) gene refine differential diagnostic criteria in renal cell carcinoma. $J$ Surg Oncol 2002;80:52-60.

23. Foster $\mathbb{K}$, Prowse A, van den Berg A, et al. Somatic mutations of the von Hippel-Lindau disease tumour suppressor gene in non-familial clear cell renal carcinoma. Hum Mol Genet 1994;3:2169-73.

24. Kondo $K$, Yao $M$, Yoshida $M$, et al. Comprehensive mutational analysis of the VHL gene in sporadic renal cell carcinoma: relationship to clinicopathological parameters. Gene Chromosome Canc 2002;34:58-68.

25. Gallou C, Joly D, Mejean A, et al. Mutations of the VHL gene in sporadic renal cell carcinoma: definition of a risk factor for VHL patients to develop an RCC [In Process Citation]. Hum Mutat 1999;13:464-75.

26. Gallou $\mathrm{C}$, Longuemaux S, Delomenie C, et al. Association of GSTT1 non-null and NAT1 slow/rapid genotypes with von Hippel-Lindau tumour suppressor gene transversions in sporadic renal cell carcinoma. Pharmacogenetics $2001 ; 11: 521-35$.

27. Ma X, Yang K, Lindblad P, Egevad L, Henminki $K$. VHL gene alterations in renal cell carcinoma patients: novel hotspot or founder mutations and linkage disequilibrium. Oncogene 2001;20:5393-400.

28. Suzuki $H$, Ueda $T$, Komiya $A$, et al. Mutational state of von Hippel-Lindau and adenomatous polyposis coli genes in renal tumors. Oncology 1997;54:252-7.

29. Yang $K$, Lindblad $P$, Egevad $L$, Hemminki $K$. Novel somatic mutations in the VHL gene in Swedish archived sporadic renal cell carcinomas [In Process Citation]. Cancer Lett 1999;141:1-8.

30. Hamano K, Esumi M, Igarashi $H$, et al. Biallelic inactivation of the von Hippel-Lindau tumor suppressor gene in sporadic renal cell carcinoma. Journal of urology 2002;167:713-7.

31. Beroud C, Collod-Beroud G, Boileau C, Soussi T, Junien C. UMD (Universal mutation database): a generic software to build and analyze locus-specific databases. Hum Mutat 2000; $15: 86-94$.

32. Novick AC, Campbell SC. 75. Renal tumors. In: Walsh PC, Retik AB, Darracott Vaughan Jr E, et al., eds. Campbell's Urology, eighth ed. Philadelphia: Saunders, 2002:2672-719.

33. Zhuang Z, Gnarra JR, Dudley $\mathrm{CF}$, Zbar B, Linehan WM, Lubensky LA. Detection of von Hippel-Lindau disease gene mutations in paraffin-embedded sporadic renal cell carcinoma specimens, Mod Pathol 1996;9:838-42.

34. Williams $\mathrm{C}$, Ponten $\mathrm{F}$, Moberg $\mathrm{C}$, et al. A high frequency of sequence alterations is due to formalin fixation of archiwal specimens. Am J Pathol 1999;155:1467-71.

35. Maynard MA, Ohh M. Von Hippel-Lindau tumor suppressor protein and hypoxia-inducible factor in kidney cancer. Am J Nephrol $2004 ; 24: 1-13$.

36. IViopoulos $\mathrm{O}$, Ohh $\mathrm{M}$, Kaelin WG, Jr. pVHL19 is a biologically active product of the von Hippel-Lindau gene arising from internal translation initiation. Proc Natl Acad Sci U S A 1998;95:11661-6.

37. Blankenship C, Naglich JG, Whaley JM, Seizinger B, Kley N. Alternate choice of initiation codon produces a biologically active product of the von Hippel Lindav gene with tumor suppressor activity. Oncogene 1999;18:1529-35.

38. Schoenfeld A, Davidowitz EJ, Burk RD. A second major native von Hippel-Lindau gene product, initiated from an internal translation start site, functions as a tumor suppressor. Proceedings of the National Academy of Sciences of the United States of America 1998;95:8817-22. 


\title{
Cigarette smoking, von Hippel-Lindau gene mutations and sporadic renal cell carcinoma
}

\author{
Boukje A.C van Dijk \\ Leo J. Schouten \\ Egbert Oosterwijk \\ Christina A. Hulsbergen-van de Kaa \\ Lambertus A.L.M Kiemeney \\ R. Alexandra Goldbohm \\ Jack $A$. Schalken \\ Piet A. van den Brandt \\ Submitted for publication
}




\section{Abstract}

Cigarette snoking is a known risk facter for renal cell carcinoma (RCC) with a modestly increased rate ratio (RR) and a positive dose-response relation. Von Hippe-Lindau (WHL) gene mutations are considered a primary ewent in the carcinogenesis of RCC. We investigated whether smoking is assaciated with mutations in the $N H L$ gene in sparadic RCC.

The Netherlands Cohort Study on diet and cancer (NLCS) includes 120,852 persons, who completed a selfadministered questionnaire on smoking habits and other factors. After 11.3 years of follow-up, 337 cases and a random sample of 5,000 persons (subcohort) were used in a case-cohort approach. Collected tumor DNA. (N=235) was analyzed for $V H L$ gene mutations. RRs and corresponding $95 \%$ confidence intervals (CI) were estimated using Cox propottional hazard models, adjusting for age, sex and body mass index.

For men, RRs for total RCC were $1.52(95 \% \mathrm{Cl}: 0.89-2.59)$ and $2.07(95 \% \mathrm{Cl}: 1.20-3.56)$ for ex- and current sinokers compared to never smokers, respectively. Estimates for women equaled 0.95 (95\% CI: 0.57-1.59) and $\$ .37$ (95\% Cl: $0.87-2.16$ ), respectively. For men, RRs for current smokers compared to never smokers were $2.34(95 \% \mathrm{Cl}: 0.79-6.94)$ and 2.95 (95\% Cl:0.65-13.28) for $V H L$ gene mutated and $V H L$ wildtype tumors, respectively. For women, these estimates were $0.82(95 \% \mathrm{Cl}: 0.35-1.93)$ and 2.04 (95\% Cl:0.94$4.45)$, respectively. Results have to be interpreted cautiously because of small numbers.

Smoking was associated with RCC risk of men, but not specifically with VHL gene mutations, irrespective of sex, suggesting that smoking may cause RCC independent of VHL gene mutations. 


\section{Introduction}

Renal Cell Carcinoma ( $R C C$ ) is the ninth most common tumor in the European Union' and is associated with a 5-year survival of approximately $55 \%{ }^{2}$. Both the incidence and mortality rates are about twice as high for males than females 1 .

Mutations in the von Hippel-Lindau (VHL) gene are perceived to be an early event in renal carcinogenesis and are mainly observed in tumors of the most common histological subtype, clear-cell $\mathrm{RCC}^{3}$. Mutations are observed in the entire gene and usually lead to a truncated inactive protein ${ }^{3}$. The $V H L$ gene is a tumor suppressor gene involved in cell cycle regulation, regulation of hypoxia inducible genes and proper fibronectin assembly in extracellular matrix ${ }^{4,5}$. It is estimated that 56 to $69 \%{ }^{4}$ of clearcell renal tumors harbor a mutation in the $V H L$ gene.

Occupational exposure to trichloroethylene ${ }^{6,7}$ and consumption of citrus fruit and vegetables (confined to smokers) ${ }^{8}$ have been linked to $V H L$ gene mutations in renal cell carcinoma ( $\mathrm{RCC}$ ) in previous studies ${ }^{6-8}$. There was no difference in the proportion of smokers for cases with or without a $V H L$ gene mutation, but in this case-only study by Hemminki et al. no comparison to the population could be made ${ }^{8}$. To our knowledge, there are no other reports on an association of smoking and $V H L$ gene mutations published thus far.

A recent meta-analysis on cigarette smoking in relation to renal cell carcinoma (RCC) concluded that inhaled tobacco smoke is clearly implicated in the etiology of RCC. Risk was increased for former (RR: $1.21 ; 95 \% \mathrm{CI}$ : 1.07-1.36) and current (RR: 1.45; 1.26-1.66) smokers with a strong dose-dependent increase in risk ${ }^{9}$. It has also been shown that cigarette smoke metabolites can cause mutations in human DNA, which is not restricted to tissues directly exposed to tobacco smoke ${ }^{10}$. Moreover, it has been reported that specific constituents can cause specific mutations ${ }^{10-12}$. Also, cigarette smoke metabolites have been shown in urine ${ }^{13}$.

We investigated whether cigarette smoking is associated with sporadic $\mathrm{RCC}$ and with mutations in the $V H L$ gene in clear-cell RCC in a prospective cohort study.

\section{Materials and methods}

\section{Subjects}

The Netherlands Cohort Study on diet and cancer is a prospective cohort study, which started in September 1986. The study design has been reported in detail elsewhere ${ }^{14}$. Briefly, the cohort included 120,852 men and women, aged 55-69 years, at the beginning of the study. The study was designed as a case-cohort study, using all cases and a random sample of 5,000 persons from the cohort (subcohort), who have been followed to estimate the accumulated person-years in the entire cohort ${ }^{15}$. Follow-up for incident cancer has been established by computerized record linkage with the 
Netherlands Cancer Registry and PALGA, a national database of pathology reports. The method of record linkage to obtain information on cancer incidence has been described previously $y^{16}$. The completeness of cancer follow-up was estimated to be more than 96 percent ${ }^{17}$. From 1986 to 1997 (11.3 years follow up) 355 kidney cancer cases (ICD-0-3: C64.9) were identified. Urothelial cell carcinomas were excluded and only histologically confirmed epithelial cancers were included (ICD-O: M8010-8119, 8140-8570), Jeaving 337 cases. All participants who reported prevalent cancer (excluding skin cancer) at baseline were excluded from analyses (leaving 4,774 subcohort members).

\section{VHL gene mutation analysis}

Paraffin material of cancer cases was collected after approval by the Medical Ethical Committees of Maastricht University, PALGA and the Netherlands cancer registry. We were able to collect paraffin blocks of tumors for 251 cases from 51 pathology laboratories, which we described in detail elsewhere ${ }^{18}$. One experienced pathologist (CAHK) revised all HE-stained slides. The RCC were classified according to the World Health Organization (WHO) classification of Tumours of $2002^{19}$. DNA isolation and mutation analyses have been described previously ${ }^{18}$. Briefly, paraffin was removed with xylene and DNA was extracted by salt-precipitation. The entire gene was amplified using 6 primer sets. Samples were first subjected to PCR-SSCP analysis, which was followed by direct sequencing in case of aberrant or equivocal results. Mutations were identified by visual inspection of sequences provided by the ABI basecaller. After revision and $V H L$ gene mutation analyses, data was available for 235 cases $^{18}$.

\section{Questionnaire}

At baseline, all cohort members completed a mailed, self-administered questionnaire on dietary habits (food-frequency questionnaire), lifestyle, smoking, personal and family history of cancer and demographic data ${ }^{20}$. Questions on cigarette, cigar and pipe smoking in the questionnaire addressed smoking status (never, ex or current smoker), age at first and last exposure, frequency, duration and inhalation pattern. Brand and type of cigarette and how much of a cigarette was usually smoked was additionally questioned, as well as use of chewing and snuff tobacco. Information on smoking status was complete for 336 cases and 4,762 subcohort members.

\section{Statistical analysis}

Differences between cases with and without collected tumor material, between men and women and between cases with and without a mutation in the VHL gene were assessed by calculating student t-tests and chi-square tests. RRs were calculated for never, exand current smokers. All analyses were also carried out for men and women separately because of the difference in smoking habits between men and women. Most men were 
current or ex-smokers while most women were never smokers in this cohort Case groups were defined as follows: total RCC (all cases of RCC detected by linkage to cancer and pathology registry; $\mathrm{N}=337$ ); clear-cell $\mathrm{RCC}$ (all cases of RCC classified as clear-cell after revision by one experienced pathologist (CAHK); $\mathrm{N}=187$ ); WHL mutated clear-cell RCC (clear-cell RCC with a mutation in the $V H L$ gene; $\mathrm{N}=114$ ) and $V H L$ wildtype clear-cell RCC (clear-cell RCC without a mutation in the VHL gene; $\mathrm{N}=73$ ).

Furthermore, the association of smoking and specific type and location of mutations were investigated. Specifically, the total number of $\mathrm{G}: \mathrm{C} \rightarrow \mathrm{T}: \mathrm{A}^{12}$ transversions, which has been linked to the carcinogenic tobacco smoke constituent benzo (a) pyrene diol epoxide (BPDE) and the number of $\mathrm{G}: \mathrm{C} \rightarrow \mathrm{A}: \mathrm{T}^{11,12}$ transitions, which has been linked to $\mathrm{N}$-nitrosamino compounds, another carcinogenic cigarette smoke constituent.

Confounders considered were age at baseline (years), sex, body mass index $\left(\mathrm{kg} / \mathrm{m}^{2}\right)$, a history of hypertension (yes/no), a family history of RCC (yes/no), alcohol consumption (g/day), social economic status (SES) based on education, physical activity in leisure time $(<30,30-60,60-90,>90 \mathrm{~min} /$ day $)$, occupational physical activity (for men only) $(<8,8-12,>12 \mathrm{kj} / \mathrm{min}$ ), vegetable ( $\mathrm{g} /$ day) and fruit consumption ( $\mathrm{g} /$ day) and energy intake (kcal/day). Those variables that were found to statistically significantly $(p<0.05)$ contribute to the multivariable model for overall RCC (age at baseline and sex), using the Wald test, were included as covariates in multivariable analyses. Confounders entered in smoking status analyses were age, sex (if appropriate) and BMI. Cigar and pipe smoking (never, ex- and current smoker) were additionally included in the model to account for other sources of tobacco smoke. To assess dose response relations, the number of cigarettes smoked per day was categorized into $<10$, $10-20,20-30$ and 30 or more cigarettes per day (additionally adjusted for the number of smoking years), and the number of smoking years was categorized into $<20,20-40$ and 40 or more smoking years (additionally adjusted for number of cigarettes smoked per day). Age at first exposure $(<15,15-17,17-20$ and 20 or older at first exposure) and years of cessation ( $<5,5-20$ or more than 20 years) were also investigated, with additional adjustment for the number of cigarettes smoked per day.

RRs and corresponding 95\% confidence intervals (CI) were estimated using Cox proportional hazard models processed with STATA (STATA statistical software, Release 7, STATA Corporation, College Station, TX, USA, 2001), after testing the proportional hazards assumption using scalled Schoenfeld residuals ${ }^{21}$. Standard errors were estimated using the robust Huber-White sandwich estimator to account for additional variance introduced by sampling from the cohort ${ }^{22}$. To obtain $p$ values for dose-response trends, ordinal exposure variables were fitted as continuous terms. Two sided $p$ values are reported throughout this paper. 


\section{Results}

Table 5.1 shows baseline characteristics of potential confounders and smoking variables for subcohort members, all cases and cases with collected tumor material, separately for men and women. First, we checked whether the ability to collect tumor tissue introduced bias. There were no statistically significant differences in mean age, the proportion of men, or the distribution over the smoking categories never, ex- and current smokers (men and women combined) between cases with $(\mathrm{N}=235)$ or without $(\mathrm{N}=102)$ tumor tissue. The mean age was somewhat higher for cases than for subcohort members (table 5.1). A positive family history for RCC was seldomly reported, with only slight differences between subcohort members and cases. The distribution of cases in smoking categories differed between men and women; there were almost no male never smokers while female smokers were scarce.

Table 5.1 Description of possible confounding variables and smoking wariables for men and women, Netherlands cohort study on diet and cancer, 1986-1997.

\begin{tabular}{|c|c|c|c|c|c|c|}
\hline \multirow[b]{2}{*}{ Variable } & \multicolumn{3}{|c|}{ Men } & \multicolumn{3}{|c|}{ Women } \\
\hline & Subcolnort & RCC cases & $\begin{array}{c}\mathrm{RCC} \text {, tumor } \\
\text { tisisue } \\
\text { collected }\end{array}$ & Sulbeohort & RCC cases & $\begin{array}{l}\mathrm{RCC} \text {, tumor } \\
\text { tissiue } \\
\text { collected }\end{array}$ \\
\hline & $N=2331$ & $N=217$ & $\mathbb{N}=148$ & $\mathbb{N}=2431$ & $N=119$ & $N=87$ \\
\hline Age-Mean (sd) & $61.4(4.2)$ & $62.0(3.8)$ & $6.2 .2(3.8)$ & $61.5 .(4.3)$ & $61.8(4.0)$ & $61.6(4.0)$ \\
\hline Family history of RCC $-\mathrm{N}(\%)$ & $14(0.6)$ & $3(1.4)$ & $2(1.4)$ & $33(0.4)$ & $10.8 \mathrm{~g}$ & $1(1.2)$ \\
\hline \multirow[t]{2}{*}{ History of hypertension - N $(\%)$} & $534(229)$ & $56(25.8)$ & $37(25,6)$ & $700(28.8)$ & $41(34.5)$ & $31(35.6)$ \\
\hline & $N=2247$ & $N=210$ & $N=\| 1$ & $N=2341$ & $N=113$ & $N=82$ \\
\hline \multirow[t]{2}{*}{ BMI - Mean (sd) } & $25.0(2.6)$ & $25.3(2.7)$ & $25.4(2.6)$ & $25.1(3.6)$ & $25.8(3.4)$ & $25.7(3.2)$ \\
\hline & $N=2331$ & $N=2.17$ & $N=14 \mathbb{8}$ & $N=2431$ & $N=119$ & $\mathrm{~N}=887$ \\
\hline \multirow[t]{2}{*}{ Cigarette suroking } & $300(129)$ & $18(8.3)$ & $12(8.1)$ & $1,431(58.9)$ & $66(5.5 .5)$ & $49(56.3)$ \\
\hline & $1.175(50.4)$ & $108(49.8)$ & $79(53.4)$ & $491(20.2)$ & $21(17.6)$ & $15(17.2)$ \\
\hline Current - N (\%) & $856(36.7)$ & $91(41.9)$ & $57(38.5)$ & $509(20,9)$ & $32(26.9)$ & $23(26.4)$ \\
\hline Never stroker - N $(\%)$ & $217(9.3)$ & $11(5.1)$ & $6(4.1)$ & $1431(58.9)$ & $64(53.8)$ & $48(55.2)$ \\
\hline Cigarette only smoker $-N(\%)$ & $1413(60: 6)$ & $136(62.7)$ & $86(58.1)$ & $995(40.9)$ & $53(44.5)$ & $38(43.7)$ \\
\hline Cigar and/or pipe smoker - N $(\%)$ & $83(3.6)$ & $7(3.2)$ & $6(4.1)$ & 0 & $2(1.7)$ & $1(1.2)$ \\
\hline $\begin{array}{l}\text { Cigatette and other type of tobacco } \\
\text { smoker - N }(\%)\end{array}$ & $618(26.5)$ & $63(29,0)$ & $50(33.8)$ & $5(0.2)$ & 0 & 0 \\
\hline
\end{tabular}

Table 5.2 shows multivariable adjusted analyses for smoking with different endpoints for the total group and stratified by sex. For women, cigar or pipe smoking were not included in the model since only 2 female cases smoked cigars (table 5.1). RRs are generally stronger for men, with statistically significantly increased risks for men only (table 5.2). However, no statistical significant interactions were observed for smoking 
with sex. The RRs were higher for $V H L$ wildtype clear-cell tumors than for mutated clear-cell tumors. This was observed both in men and women. The number of male never smokers, which was also the reference group, was very low for the molecular endpoints. Therefore these analyses were repeated using current smokers as a reference group to increase precision of estimates. Conclusions did not change (data not shown).

Table 5.2 Rate ratios for ex-and current smokers compared to never smokers for all tumors (total), clearcell tumors, clear-cell tumors with a VHL gene mutation and $V H L$ wildype clear-cell cases, Netherlands cohort study on diet and cancer (1986-1997).

\begin{tabular}{|c|c|c|c|c|c|c|c|c|c|c|}
\hline & \multicolumn{3}{|c|}{ Never smokers } & \multicolumn{3}{|c|}{ Ex-smokers } & \multicolumn{3}{|c|}{ Current smokess } & \multirow[b]{2}{*}{$\begin{array}{l}p \text { value for } \\
\text { intertaction }\end{array}$} \\
\hline & $\begin{array}{c}\text { Cases } \\
(\mathrm{N})\end{array}$ & $\begin{array}{c}\text { Person-years } \\
\text { subiooluont }\end{array}$ & & $\begin{array}{l}\text { Cases } \\
\text { (N) }\end{array}$ & $\begin{array}{c}\text { Person-years } \\
\text { subcohort }\end{array}$ & $\begin{array}{c}\mathrm{RR} \\
(95 \% \mathrm{CI})\end{array}$ & $\begin{array}{l}\text { Cases } \\
(\mathrm{N})\end{array}$ & $\begin{array}{c}\text { Person-years } \\
\text { subeohort }\end{array}$ & $\begin{array}{c}\mathrm{RR} \\
(95 \% \mathrm{Cl})\end{array}$ & \\
\hline \multicolumn{11}{|c|}{ Men \& women } \\
\hline Tolal & 81 & 17,906 & 1 & 125 & 16,759 & $\begin{array}{c}1.17 \\
(0.85-1.61)\end{array}$ & 117 & 13,377 & $\begin{array}{c}1.60 \\
(1.17-2.20)\end{array}$ & 0,43 \\
\hline Clear-cell & 48 & 17,906 & $\mathbb{H}$ & 73 & 16,759 & $\begin{array}{c}1.34 \\
(0.91-1.99)\end{array}$ & 57 & 13,377 & $\begin{array}{c}1.49 \\
(0.98-2.26)\end{array}$ & 0.20 \\
\hline $\begin{array}{l}\text { Clear-cell } \\
\text { willdype }\end{array}$ & 18 & 17,906 & $\|$ & 27 & 16,759 & $\begin{array}{c}1.58 \\
(0.84 \times 2.94)\end{array}$ & 26 & 13,377 & $\begin{array}{c}2.06 \\
(1.07-3.94)\end{array}$ & 0.55 \\
\hline $\begin{array}{l}\text { Clear-cell } \\
\text { mutated }\end{array}$ & 30 & 17,9006 & 1 & 46 & 16,759 & $\begin{array}{c}1.20 \\
(0.73-11.96)\end{array}$ & 31 & 13,377 & $\begin{array}{c}1.17 \\
(0.69-1.99)\end{array}$ & 0.24 \\
\hline \multicolumn{11}{|l|}{ Ment } \\
\hline Total & 17 & 3,086 & 1 & 105 & 11,643 & $\begin{array}{c}1.52 \\
(0.89-2.59)\end{array}$ & 88 & 8,176 & $\begin{array}{c}2.07 \\
(1.20-3.56)\end{array}$ & \\
\hline Clear-cell & 6 & $3,0 \% 6$ & 1 & 60 & 11,643 & $\begin{array}{c}2.43 \\
(1.07-5.56)\end{array}$ & 39 & 8,176 & $\begin{array}{c}2.54 \\
(1.05-6.17)\end{array}$ & \\
\hline $\begin{array}{l}\text { Clear-cell } \\
\text { wildtype }\end{array}$ & 2 & 3,086 & 1 & 21 & 11,643 & $\begin{array}{c}2.68 \\
(0.66-10.86)\end{array}$ & 15 & 8,176 & $\begin{array}{c}2.95 \\
(0.65-13.28)\end{array}$ & \\
\hline $\begin{array}{l}\text { Clear-cell } \\
\text { mutaled }\end{array}$ & 4 & 3,0866 & 1 & 39 & $11_{0} 643 i$ & $\begin{array}{c}2.33 \\
(0.84-6.44)\end{array}$ & 24 & 8,176 & $\begin{array}{c}2.34 \\
(0.7946 .94)\end{array}$ & \\
\hline \multicolumn{11}{|l|}{ Wonneri } \\
\hline Tratal & 64: & 14,820 & 1 & 20 & 5,116 & $\begin{array}{c}0.95 \\
(0.57 \cdot 1.59)\end{array}$ & 29 & 5,201 & $\begin{array}{c}1.37 \\
(0.87+2.16)\end{array}$ & \\
\hline Clear-cell & 42 & 14,820 & 1 & 13 & 5,116 & $\begin{array}{c}0.94 \\
(0.50-11.76)\end{array}$ & 18 & 5,201 & $\begin{array}{c}1.29 \\
(0.73-2.28)\end{array}$ & \\
\hline $\begin{array}{l}\text { Clear-cell } \\
\text { wildype }\end{array}$ & 16 & 14,820 & 1 & 6 & 5,116 & $\begin{array}{c}1.12 \\
(0.44-2.86)\end{array}$ & 11 & 5,201 & $\begin{array}{c}2.04 \\
(0.94-4.45)\end{array}$ & \\
\hline $\begin{array}{l}\text { Clearmeell } \\
\text { mutated }\end{array}$ & 26 & 14,820 & 1 & 7 & 5,116 & $\begin{array}{c}0.82 \\
(0.35-1.92)\end{array}$ & 7 & 5,201 & $\begin{array}{c}0.82 \\
(0.35+1.93)\end{array}$ & \\
\hline
\end{tabular}

a Reference group; "Test for interaction of sex and smoking; "Cigarette, cigar and plpe smoking, multivariable adjusted for age, sex and BMI: "Cigarette, cigar and pipe smoking, multivariable adjusted for age and BMI: Cigarette smoking, multivariable adjusted for age and BMl. 
Table 5.3 shows additional cigarette smoking features for men who smoke(d). The number of females who smoke(d) was too small for meaningful analyses. Risk of RCC increased with increasing smoking frequency (number of cigarettes/day) and to a lesser extent with smoking duration (the number of years smoked). Age at first exposure was not associated with RCC risk. The risk of RCC was mostly lower after cessation although no clear trend was present. There were no noteworthy differences between mutated and wildtype clear-cell RCC.

The distribution of smokers for the different type of mutations, the mutational spectra, specific mutations (i.e., G:C $\rightarrow \mathrm{T}: \mathrm{A}$ transversions and $\mathrm{G}: \mathrm{C} \rightarrow \mathrm{A}: \mathrm{T}$ transitions) and location of mutations is shown in table 5.4. There did not seem to be a difference between never, ex- and current smokers.

\section{Discussion}

We observed an increased risk of RCC with cigarette smoking for men, with a suggestion of an increasing risk with number of cigarettes smoked per day. This association was less clear for women. Risks were somewhat higher for tumors without a VHL gene mutation compared to tumors with one. This indicates that the number of mutations in the $V H L$ gene was not increased by smoking, even though it has been clearly shown that cigarette smoking is associated with mutations in other genes such as p.53.

Many studies have reported on smoking as a risk factor for $\mathrm{RCC}$. Almost all concluded that smoking was associated with an increased risk and most observed increasing risks, not only with the number of cigarettes smoked per day but also with the number of years smoked and decreasing risks with number of years since cessation, as is also shown in the meta-analysis by Hunt et $a l$. . We observed a difference in risk between men and women, which was also observed in the meta-analysis ${ }^{9}$. This is probably the result of the difference in exposure between men and women, and maybe of different smoking habits. In the subcohort, female ex- and current smokers usually smoked filter-tipped cigarettes (60\%), while male ex-and current smokers mainly smoked nonfiltered cigarettes $(65 \%)$.

The percentage of smokers in this cohort appears to be slightly lower compared to the percentage in the population. In the subcohort, $37 \%$ of men reported to be a current smoker while $21 \%$ of women reported to be current smokers. A report on percentages of male and female smokers in the age groups of 50-65 and 65t in 1986 in the Netherlands reports $45 \%$ and $41 \%$ smokers for men and $29 \%$ and $12 \%$ smokers in women ${ }^{23}$. This difference may be the result of a selective response by smoking status to the baseline questionnaire or of underreporting of smoking habits because of social desirability. The response rate to the questionnaire at baseline equalled $35.5 \%{ }^{14}$, with a slight shift towards non-smoking compared to the population ${ }^{24}$. This selective response would not lead to altered RRs, while underreporting would result in an underestimation of the RRs. 


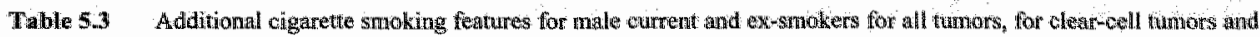
for clear-cell tumors with or without mutation, Netherlands cohor study an diet and cancer, $1986-1997$.

\begin{tabular}{|c|c|c|c|c|c|c|c|c|c|}
\hline \multirow[b]{2}{*}{$\begin{array}{l}\text { Cilgarete smoking } \\
\text { fatwires }\end{array}$} & \multirow[b]{2}{*}{$\begin{array}{l}\text { Person-years } \\
\text { subcolhort }\end{array}$} & \multicolumn{2}{|r|}{ All tumors } & \multicolumn{2}{|r|}{ Chear-cell } & \multirow{2}{*}{$\begin{array}{c}\text { Cases } \\
\text { (N) }\end{array}$} & \multirow{2}{*}{ 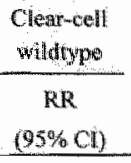 } & \multirow{2}{*}{$\begin{array}{c}\text { Cases } \\
\text { (N) }\end{array}$} & \multirow{2}{*}{$\begin{array}{c}\text { Clear-oll } \\
\text { mutated } \\
\text { RR } \\
(9 \% \text { CD }\end{array}$} \\
\hline & & $\begin{array}{c}\text { Cases } \\
\text { (N) }\end{array}$ & $\begin{array}{c}\text { RR } \\
(95 \% \mathrm{CD}) \\
\end{array}$ & $\begin{array}{l}\text { Cases } \\
\mathrm{ND}\end{array}$ & $\begin{array}{c}\mathrm{RR} \\
(95 \% \mathrm{CI}) \\
\end{array}$ & & & & \\
\hline \multicolumn{10}{|c|}{ Frequency (cigarettes/day) } \\
\hline$<10$ & 3,489 & 31 & $\frac{1}{\text { (reference) }}$ & 14 & $\begin{array}{c}1 \\
\text { (reference) }\end{array}$ & 6 & $\begin{array}{c}1 \\
\text { (reference) }\end{array}$ & 8 & $\begin{array}{c}1 \\
\text { (reforence) }\end{array}$ \\
\hline $10-<20$ & 6,643 & 58 & $\begin{array}{c}0.93 \\
(0.58-1.48)\end{array}$ & 28 & $\begin{array}{c}1.01 \\
(0.51-1.99)\end{array}$ & 10 & $\begin{array}{c}0.84 \\
(0.29-2.44)\end{array}$ & 18 & $\begin{array}{c}1.13 \\
(0.47 \cdot 2.71)\end{array}$ \\
\hline $20<<30$ & 6,043 & 59 & $\begin{array}{c}1.04 \\
(0.65-1.67)\end{array}$ & 35 & $\begin{array}{c}1.38 \\
(0.70-2.70)\end{array}$ & 13 & $\begin{array}{c}1.21 \\
(0.44-3.37)\end{array}$ & 22 & $\begin{array}{c}1.50 \\
(0.62-3.62)\end{array}$ \\
\hline $30+$ & 1,957 & 29 & $\begin{array}{c}1.52 \\
(0.88-2.65)\end{array}$ & 16 & $\begin{array}{c}1.77 \\
(0.83-3.79)\end{array}$ & 6 & $\begin{array}{c}1.61 \\
(0.51-5.15)\end{array}$ & 10 & $\begin{array}{c}1.89 \\
(0.71 \times 5.06)\end{array}$ \\
\hline prallue for trend & & & 0.16 & & 0.08 & & 0.32 & & 0.14 \\
\hline $\begin{array}{l}\text { Continucus per } 10 \\
\text { cigarettes/day }\end{array}$ & 18,132 & 177 & $\begin{array}{c}1.14 \\
(0.99-1.31)\end{array}$ & 93 & $\begin{array}{c}1.19 \\
(1.00-1.42)\end{array}$ & 35 & $\begin{array}{c}1.26 \\
(0.94-1.69)\end{array}$ & 58 & $\begin{array}{c}1.16 \\
(0.94-1.41)\end{array}$ \\
\hline \multicolumn{10}{|l|}{ Duration (years) } \\
\hline 20 & 2,625 & 21 & $\begin{array}{c}1 \\
\text { (reference) }\end{array}$ & 13 & $\begin{array}{c}\text { l } \\
\text { (reference) }\end{array}$ & 4 & $\begin{array}{c}1 \\
\text { (roference) }\end{array}$ & 9 & $\begin{array}{c}1 \\
\text { (rofetencis) }\end{array}$ \\
\hline $20<<0$ & 8,299 & 78 & $\begin{array}{c}1.09 \\
(0.66-1.80)\end{array}$ & $43 i$ & $\begin{array}{c}0.97 \\
(0.51-1.84)\end{array}$ & 17 & $\begin{array}{c}1.20 \\
(0.40-3.60)\end{array}$ & 26 & $\begin{array}{c}0.86 \\
(0.39-1.89)\end{array}$ \\
\hline $40+$ & 7,208 & 78 & $\begin{array}{c}1.25 \\
(0.75-2.08)\end{array}$ & 37 & $\begin{array}{c}1.03 \\
(0.53-2.01)\end{array}$ & 1.4 & $\begin{array}{c}1.20 \\
(0.41-3.51)\end{array}$ & 23 & $\begin{array}{c}0.96 \\
(0.42-2.19)\end{array}$ \\
\hline$p$ value for trend & & & 0.33 & & 0.86 & & 0.80 & & 0.99 \\
\hline $\begin{array}{l}\text { Continuous per } 10 \\
\text { years }\end{array}$ & 18,132 & 177 & $\begin{array}{c}1.10 \\
(0.94-1.28)\end{array}$ & 93 & $\begin{array}{c}1.07 \\
(0.88-1.30)\end{array}$ & 35 & $\begin{array}{c}1.10 \\
(0.82-1.49)\end{array}$ & 58 & $\begin{array}{c}1.05 \\
(0.81-1.36)\end{array}$ \\
\hline \multicolumn{10}{|c|}{ Age at first exposure (years) } \\
\hline$<15$ & 4,073 & 41 & $\begin{array}{c}1 \\
\text { (reference) }\end{array}$ & 21 & $\begin{array}{c}\Downarrow \\
\text { (reference) }\end{array}$ & 8 & $\begin{array}{c}1 \\
\text { (reference) }\end{array}$ & 13 & $\begin{array}{c}1 \\
\text { (reference) }\end{array}$ \\
\hline $15<17$ & 5,289 & 46 & $\begin{array}{c}0.89 \\
(0.57-1.39)\end{array}$ & 28 & $\begin{array}{c}1.09 \\
(0.61 \times 1.96)\end{array}$ & 13 & $\begin{array}{c}1.41 \\
(0.58-3.48)\end{array}$ & 15 & $\begin{array}{c}0.91 \\
(0.43-1.92)\end{array}$ \\
\hline $17-<20$ & 5,371 & 51 & $\begin{array}{c}0.96 \\
(0.62-1.48)\end{array}$ & 24 & $\begin{array}{c}0.89 \\
(0.481 .64)\end{array}$ & 7 & $\begin{array}{c}0.70 \\
(0.24-1.99)\end{array}$ & 17 & $\begin{array}{c}0.99 \\
(0.47-209)\end{array}$ \\
\hline $20+$ & 3,537 & 38 & $\begin{array}{c}1.07 \\
(0.66-1.72)\end{array}$ & 20 & $\begin{array}{c}1.17 \\
(0.61-224)\end{array}$ & 7 & $\begin{array}{c}1.12 \\
(0.39-3.20)\end{array}$ & 13 & $\begin{array}{c}1.20 \\
(0.54 \mathrm{~m} 267)\end{array}$ \\
\hline p walue for trend & & & 0.74 & & 0.87 & & 0.72 & & 0.63 \\
\hline \multicolumn{10}{|c|}{ Years since cessation } \\
\hline Cument smoker & 7,212 & 77 & $\begin{array}{c}1 \\
\text { (reference) }\end{array}$ & 34 & $\begin{array}{c}1 \\
\text { (reference) }\end{array}$ & 14 & $\begin{array}{c}1 \\
\text { (refterence) }\end{array}$ & 20 & $\begin{array}{c}\mathrm{I} \\
\text { (refereneo) }\end{array}$ \\
\hline$<5$ & 1,503 & 19 & $\begin{array}{c}0.98 \\
(0.56 \cdot 1.71)\end{array}$ & 12 & $\begin{array}{c}1.33 \\
(0.66-2.65)\end{array}$ & 3 & $\begin{array}{c}0.83 \\
(0.242 .85)\end{array}$ & 9 & $\begin{array}{c}1.69 \\
(0.71-3.81)\end{array}$ \\
\hline $5-<20$ & 6,059 & 46 & $\begin{array}{c}0.58 \\
(0.37-0.89)\end{array}$ & 26 & $\begin{array}{c}0.68 \\
(0.37-1.23)\end{array}$ & 9 & $\begin{array}{c}0.59 \\
(0.23-1.48)\end{array}$ & 17 & $\begin{array}{c}0.75 \\
(0.34 \times 1.61)\end{array}$ \\
\hline $20+$ & 3,604 & 3.5 & $\begin{array}{c}0.78 \\
(0.50 \cdots 1.21)\end{array}$ & 21 & $\begin{array}{c}1.01 \\
(0.50-1.83)\end{array}$ & 9 & $\begin{array}{c}1.10 \\
(0.47-2.61)\end{array}$ & $\| 2$ & $\begin{array}{c}0.96 \\
(0.44-2.12)\end{array}$ \\
\hline$p^{p}$ willue for trend & & & 0.07 & & 0.60 & & 0.87 & & 0.61 \\
\hline
\end{tabular}

- Number of cigarettes smoked per day, years of cigarette smoking, pipe and ciggar smoking, multivariable adjusted for age and BMi, "Number of stmoking years or age at first exposure or years since cessation, number of cigarettes smoked pher thy, pipe and cigar smoking, multivariable adjusted for age and BMI 
Table 5.4. Distribution of smoking (never, ex- and current) for mutational characteristics of the VHL gene for all andiated clear-cell tumors.

\begin{tabular}{|c|c|c|c|c|}
\hline & $\begin{array}{c}\text { Never smokers } \\
\text { N }(\%)\end{array}$ & $\begin{array}{c}\text { Ex-smokers } \\
N(\%)\end{array}$ & $\begin{array}{c}\text { Current smokers } \\
N(\%)\end{array}$ & p value \\
\hline \multicolumn{5}{|l|}{ Type of mutation } \\
\hline Point mutation & $16(32.0)$ & $23(46.0)$ & $11(22.0)$ & $0.16^{6}$ \\
\hline Deletion or insertion & $18(26.9)$ & $25(37.3)$ & $24(35.8)$ & $0.84^{4}$ \\
\hline \multicolumn{5}{|l|}{ Mutational spectra } \\
\hline Silent & $5(38.5)$ & $4(30.8)$ & $4(30.8)$ & $0.59^{\mathrm{b}}$ \\
\hline Missensise & $7(25.0)$ & $16(57.1)$ & $5(17.9)$ & $0.09^{2}$ \\
\hline In-frame deletion/insertion & $5(33.3)$ & $3(20.0)$ & $7(46.7)$ & $0.25^{b}$ \\
\hline Nonsense & $I(25.0)$ & $2(50.0)$ & $1(25.0)$ & $1.00^{6}$ \\
\hline Prameshift deletion/insertion & $14(26.4)$ & $21(39.6)$ & $18(34.0)$ & $1.00^{\circ}$ \\
\hline Truncating mutation & $15(26.3)$ & $23(40.4)$ & $19(33.3)$ & $1.00^{\mathrm{a}}$ \\
\hline \multicolumn{5}{|l|}{ Specific mutations } \\
\hline$G: C-T: A$ & $3(27.3)$ & $5(45.5)$ & $3(27,3)$ & $0.93^{\mathrm{b}}$ \\
\hline $\mathrm{G}: \mathrm{C} \rightarrow \mathrm{A}: \mathrm{T}$ & $5(31.3)$ & $9(56.3)$ & $2(12.5)$ & $0.19^{\mathrm{s}}$ \\
\hline \multicolumn{5}{|l|}{ Location } \\
\hline Exon 1 & $18(29.5)$ & $24(39.3)$ & $19(31,2)$ & $0.83^{\mathrm{a}}$ \\
\hline Exon 2 & $7(25.9)$ & $12(44.4)$ & $8(29.6)$ & $0.87^{\mathrm{a}}$ \\
\hline Exon 3 & $6(26.1)$ & $9(39.1)$ & $8(34.8)$ & $1.00^{\mathrm{B}}$ \\
\hline Intron & $3(33.3)$ & $4(44.4)$ & $2(22.2)$ & $0.76^{b}$ \\
\hline
\end{tabular}

"chi-square test of variable ws. remainder (other types/locations of mutations and VHL wildtype); ${ }^{\text {b Fisher- }}$ Exact test because at least one expected value equals less than 2 or more than $20 \%$ of expected values equal less than 5 .

Then the question remains whether we measured smoking at the most relevant period of life. Latency is unknown, but a latency of decades seems plausible. Most of the ever smokers in the subcoliort had smoked for 20 years or more $(86.0 \%$ of men and $75.5 \%$ of women), while $42.2 \%$ of men and $23.7 \%$ of women had smoked for 40 years or more. Also, $77.0 \%$ of men and $36.7 \%$ of women started smoking before the age of nineteen. These percentages are sufficiently high to assume that smoking could have caused cancer within the time frame measured by this study.

Because smoking is associated with risk of RCC and its constituents have been shown to cause mutations and the $V H L$ tumor suppressor gene is considered to be one of the primary events in the carcinogenesis of RCC, we hypothesized smoking to be associated with VHL gene mutations. Contrary to what we expected, RRs were somewhat higher for $V H L$ wildtype tumors than for $V H L$ mutated tumors, regardless of sex. We also did not find an association of smoking and type of $V H L$ gene mutations or with specific types of mutations implicated with exposure to cigarette smoke constituents. The observation that smoking, specifically exposure to BPDE, induces $\mathrm{G}: \mathrm{C} \rightarrow \mathrm{T}: \mathrm{A}$ transversions has predominantly been reported for the $p 53$ tumor suppressor 
gene in lung cancer ${ }^{25}$ and may not apply to all genes and cancer sites. For example, in a study on bladder cancer, not one $p 53 \mathrm{G}: \mathrm{C} \rightarrow \mathrm{T}: \mathrm{A}$ transversion was observed in smokers $^{26}$. Exposure to $\mathrm{N}$-nitrosamino compounds was associated with $\mathrm{G}: \mathrm{C} \rightarrow \mathrm{A}: \mathrm{T}$ transitions in the ras gene in tumors of rodents ${ }^{12}$ and also with $V H L$ gene mutations in rats $^{\text {". }}$. We found no evidence to suggest this plays a role in humans.

To our knowledge, we are one of the first to investigate the association of risk factors with $V H L$ gene mutations. A direct association between a risk factor and mutations may give additional information on the pathway(s) that lead to tumor growth. Previously, Brauch et al. observed a positive association of occupational exposure to trichloroethylene, an industrial solvent, to VHL gene mutations and a hot spot for mutations in a case-control study ${ }^{6,7}$. However, long-term exposure to an extremely high dose of the probable carcinogen trichloroethylene was investigated. Hemminki et al. investigated the association of vegetable and fruit consumption with mutations in a case-only study ${ }^{8}$. With regard to vegetable and fruit consumption, decreased risks were observed for vegetable consumption (for smokers) and citrus consumption (for smokers and smokers and non-smokers together) in 66 tests with the number of patients per group sometimes as low as $3^{8}$. In this report, the OR for risk of $V H L$ gene mutations compared to wildtype VHL as a result of smoking equaled $0.95(95 \% \mathrm{Cl}: 0.41-2.21)$ in a case-only analysis ${ }^{8}$. This supports our observation that smoking may not be associated with $V H L$ gene mutations.

Smoking was associated with RCC risk for men but smoking was not associated with $V H L$ gene mutations, irrespective of sex, implying that smoking may cause or promote RCC independent from VHL gene mutations.

\section{Acknowledgements}

This study was financially supported by the Dutch Kidney Foundation (Grant C99.1863) and the Dutch Cancer Society. We wish to thank Dr. E. Dorant, C. de Brouwer, Prof. Dr. A. Geurts van Kessel and Prof. Dr. D. Ruiter for their preparatory work for this study; Dr. A. Volovics and Dr. A. Kester for statistical advice; S. van de Crommert, H. Brants, J. Nelissen, C. de Zwart, M. Moll, W. van Dijk, M. Jansen and A. Pisters for assistance; H. van Montfort, T. van Moergastel, L. van den Bosch and R. Schmeitz for programming assistance; and $\mathrm{K}$. van Houwelingen and $\mathrm{H}$. Gorissen for laboratory assistance. The authors also thank the staffs of the Dutch regional cancer registries and the Netherlands national database for pathology (PALGA) for providing incidence data. Finally, we would like to thank the participating pathological laboratories for providing paraffin material (for a complete list, see: ${ }^{18}$ ). 


\section{References}

1. Ferlay $I$, Bray $\mathrm{F}$, Sankila R, Parkin D. EUCAN: Cancer Incidence, Mortality and Prevalence in the European Union 1998, version 5.0. Lyon: IARCPress., 1999.

2. Coleman MP, Gatta G, Verdechia A, et al EUROCARE-3 sumary: cancer survival in Europe at the end of the 20th century. Ann Oncol 2003;14 Suppl 5:v128-49.

3. Gnarta JR, Duan DR, Weng $Y$, et al. Molecular cloning of the von Hippel-Lindau tumor suppressor gene and its rolle in renal carcinoma. Biochim Biophys Acta 1996;1242:201-10.

4. Richards FM. Molecular pathology of von Hippel-Lindau disease and the VHL tumour suppressor gene. Expert Rev Mol Med 2001;2001:1-27.

5. Kaelin WG, Jr. The von hippel-lindau tumor suppressor gene and kidney cancer. Clin Cancer Res 2004;10:6290\$-5s.

6. Brauch $\mathrm{H}_{3}$ Werrich $\mathrm{G}$, Homauer MA, Storkel S, Wohl T, Bruning T. Trichloroethylene exposure and specific somatic mutations in patients with renal cell carcinoma. I Natl Cancer Inst $1999 ; 91: 854-61$.

7. Brauch $\mathrm{H}$, Weirich $\mathrm{G}$, Klein $\mathrm{B}$, Rabstein $\mathrm{S}$, Bolt HM, Bruning T. VHL mutations in renal cell cancer: does occupational exposure to trichloroethylene make a difference? Toxicol Lett 2004;151:301-10.

8. Hemminki K, Jiang $Y$. Ma X, Yang K, Egevad L, Lindblad P. Mollecular epidemiology of VHL gene mutations in renal cell carcinoma patients: relation to dietary and other factors. Carcinogenesis 2002;23:809-15.

9. Hunt JD, van der Hel OL, McMillan GP, Boffetta P, Brennan P. Renal cell carcinoma in relation to cigarette smoking: Meta-analysis of 24 studies. Int J Cancer 2004;114:101-8.

10. Phillips DH. Smoking-related DNA and protein adducts in human tissues. Carcinogenesis 2002;23:1979-2004.

11. Shiao YH, Rice JM, Anderson LM, Diwan BA, Hard GC. von Hippel-Lindau gene mutations in $\mathrm{N}$-nitrosodimethylamine-induced rat renal epithelial tumors [see comments]. J Natl Cancer Inst 1998;90:1720-3.

12. Harris CC. Chemical and physical carcinogenesis." advances and perspectives for the $1990 \mathrm{~s}$. Cancer Res 1991;51:5023S-44S.

13. Hecht SS. Human urinary carcinogen metabolites: biomarkers for investigating tobacco and caincer. Carcinogenesis 2002;23:907-22.

14. Van den Brandt PA, Goldbohm RA, Van 't Veer P, Volovics A, Hermus RI, Sturmans F. A large-scale prospective cohort study on diet and cancer in The Netherlands. $J$ Clin Epidemiol 1990;43:285-95.

15. Volovics $\mathrm{A}$, vati den Brandt PA. Methods for the analyses of case-cohort studies. Biom $J$ $1997 ; 39: 159-214$.

16. Van den Brandt PA, Schouten LJ, Goldbohm RA, Dorant E, Humen PM. Development of a record linkage protocol for use in the Dutch Cancer Registry for Epidemiological Research. Int J Epidemiol 1990;19:553-8.

17. Goldbohm RA, Van den Brandt PA, Dorant E. Estimation of the coverage of Dutch municipalities by cancer registries and PALGA based on hospital discharge data. Tijdschr Soc Gezondheidsz 1994;72:80-4.

18. van Houwelingen KP, van Dijk BA, Hullsbergen-van de Kaa CA, at al. Prewalence of von Hippel-Lindau gene mutations in sporadic renal cell carcinoma: results from the Netherlands cohort study. BMC Cancer 2005;5:57.

19. Eble J, Sauter G, Epstein J, Sesterhenn I. World Health Organization Classification of Tumours. Pathology and Genetics. Tumours of the Urinary System and Male Genital Organs. Lyon: IARC Press, 2004. 
20. Goldbohm RA, wan den Brandt PA, Brants HA, et al. Validation of a dietary questionnaire used in a large-scale prospective cohort study on diet and cancer. Eur J Clin Nutr $1994,48: 253-65$.

21. Schoenfeld D. Partial residuals for the proportional hazards regression model. Biometrika $1982 ; 69: 239-41$.

22. Lin DY, Wei LJ. The robust inference for the Cox Proportional Hazards Model. J Am Stat Assoc $1989 ; 84: 1074-8$.

23. Cijfers en Onderzoek. Jaarverslag: STTVORO, 1999.

24. Goldbohm RA, Van den Brandt PA, Brants HA, Van 't Veer P, Sturmans F, Hermus RJJ. A self-administered questionnaire to assess dietary habits in a cohort study on diet and cancer. In: Kohlmeier L, ed. The diet history method. Proceedings of the 2nd Berlin meeting on nutritional epidemiology, Berlin, October 1989. London: Smith-Gordon, 1991:93-6.

25. Hussain SP, Amstad P, Raja K, et al. Mutability of p53 hotspot codons to benzo(a)pyrene diol epoxide (BPDE) and the frequency of 553 mutations in nontumorous human lung. Cancer Res 2001;61:6350-5.

26. Spruck $\mathrm{CH}_{4}$ 3rd, Rideout WM, 3rd, Olumi AF, et al. Distinct pattern of p53 mutations in bladder cancer: relationship to tobacco usage. Cancer Res 1993;53:1162-6. 


\section{6}

\section{Hypertension, antihypertensives and mutations in the von Hippel-Lindau gene in renal cell carcinoma: results from the Netherlands cohort study}

Leo J. Schouten Boukje A.C. van Dijk

Egbert Oosterwijk Christina A. Hulsbergen-van de Kaa Lambertus A.L.M. Kiemeney R. Alexandra Goldbohm

Jack A. Schalken Piet A. van den Brandt $J$ Hypertension 2005;23(11):1997-2004 


\section{Abstract}

\section{Objectives}

Hypertension and/or antihypertensive medication are reported to be risk factors of renal cell carcinoma (RCC). We investigated whether these risk factors are associated with von Hippel-Lindan gene (VHL) mutations in RCC.

\section{Merhods}

The Netherlands Cohort Study on Diet and Cancer (NLCS) started in 1986 (N=120,852 men and women) and uses the case-cohort methodology. After 11.3 years of follow-up, $337 \mathrm{RCC}$ cases and 4,774 subcohort members were available for analysis. DNA was isolated from paraffin-embedded tumor tissue for VHL analysils.

\section{Results}

Cohort members who reported hypertension on use of anti-hypertensive medication had a slightly (nonsignificant) increased tisk of RCC: rate ratios (RR) equaled $1.22(95 \% \mathrm{Cl} ; 0.94-1.58)$ and $1.14(95 \% \mathrm{Cl}$ : $0.85-1.52$ ), respectively. RRs were adjusted for sex, age, body matss index and cigarette smoking. Of the 235 patients for whom tumor tissue specimens were collected, 187 had a clear-eell RCC of whom 114 had a $V H L$ mutation. History of hypertension was associated with a non-significantly increased risk of clear-cell RCC with VHL mutations (RR: $1.34 ; 95 \% \mathrm{C}: 0.87-2.07$ ), and was not associated with the risk of clear-cell RCC without WHL nutations (RR: $0.88 ; 95 \%$ Cl:0.51-1.53). Use of diuretios was associated with clear-cell RCC without WHL mutations (RR: $2.11 ; 95 \%$ Cl:1.16-3.83).

\section{Conchistons}

In this study non-significantly increased risks for history of hypertension and use of antihypertensive medication witl RCC were observed. The association with hypertension was stronger in RCC patients with VHL mutations, while there was a positive association of diuretics use and risk of RCC without $V H L$ mutations. 


\section{Introduction}

Hypertension and use of diuretics or other antihypertensive medication have been found to be risk factors for renal cell carcinoma ( $R C C)$ in many epidemiological studies ${ }^{1,2}$. It is unclear, however, whether the increased risk is caused by hypertension itself, or by the use of antihypertensive medication. Some recent studies showed that diuretic medication was no longer a risk factor after controlling for the diagnosis of hypertension ${ }^{3,4}$, suggesting that not medication but hypertension is a risk factor for RCC. Several prospective studies have studied the effect of hypertension on the risk of $\mathrm{RCC}^{5-12}$, but few prospective cohort studies were also able to study the use of antihypertensive medication ${ }^{8,11,12}$.

RCC is classified in different subtypes. The majority of RCC are of the clear cell type $(\sim 80 \%)$; other subtypes are papillary RCC $(10 \%)$, chromophobe RCC $(5 \%)$, collectingduct carcinoma $(1 \%)$ and unclassified RCC $(3-5 \%)^{13}$. Von Hippel-Lindau (VHL) disease is a rare inherited disorder associated with (amongst others) an increased risk for clear-cell $\mathrm{RCC}^{14}$. After the identification of the $V H L$ gene on chromosome $3 \mathrm{p} 25$ it became evident that this gene is also involved in the development of sporadic clear-cell RCC. It is estimated that approximately $75 \%$ of all sporadic clear-cell RCC harbor biallelic $V H L$ defects ${ }^{15}$. Two studies suggested that risk factors, such as occupational exposure to trichloroethylene and fruit consumption, are associated with mutations in the $V H L$ gene in $\mathrm{RCC}^{16,17}$.

Despite the fact that many studies have observed an association between the diagnosis of hypertension and/or use of antihypertensive medication and RCC risk, there is still much uncertainty with respect to the biological mechanism. Gago-Dominguez ${ }^{18}$ suggested the 'lipid peroxidation' hypothesis as the underlying mechanism, but this remains to be proven. The different subtypes of RCC may have different etiologies. The $V H L$ gene is the main causative gene for sporadic clear-cell $\mathrm{RCC}^{15}$. Whether hypertension and/or use of antihypertensive medication are associated with clear-cell RCC, or more specifically with mutational status of the VHL gene, has not been investigated before. It is conceivable that these risk factors are associated with specific subtypes of RCC, or with mutational status of the VHL gene in clear-cell RCC.

We decided to study whether hypertension and use of antihypertensive medication were associated with risk of RCC, and more specifically with mutational status of the $V H L$ gene in clear-cell RCC, within a large prospective cohort study.

\section{Materials and methods}

\section{Subjects}

The Netherlands Cohort Study on diet and cancer is a prospective cohort study, which started in September 1986. The study design has been reported in detail elsewhere ${ }^{19}$. Briefly, the cohort included 120,852 men and women, aged 55-69 years, at the 
beginning of the study. The study was designed as a case-cohort study, using all cases and a random sample of 5,000 persons from the cohort (subcohort), who have been followed to estimate the accumulated person-years in the entire cohor ${ }^{20}$. Follow-up for incident cancer has been established by computerized record linkage with the Netherlands Cancer Registry and PALGA, a national database of pathology reports. The method of record linkage to obtain information on cancer incidence has been described previously ${ }^{21}$. The completeness of cancer follow-up was estimated to be more than $96 \%{ }^{22}$. From 1986 to 1997 (11.3 years follow up) 355 kidney cancer cases [International Classification of Diseases for Oncology, wersion 3 (ICD-O-3): C64.9] were identified. Urothelial cell carcinomas were excluded and only histologically confirmed epithelial cancers were included (ICD-O: M8010-8119, 8140-8570), leaving 337 cases. All subcohort members who reported prevalent cancer (excluding skin cancer) at baseline were excluded from analyses (leaving 4,774 subcohort members).

\section{VHL mutation analysis}

Paraffin blocks of tumors were collected from 51 pathology laboratories, the procedures have been described in detail elsewhere ${ }^{23}$. We were able to collect material for 251 cases. One experienced pathologist (CAHK) revised all haematoxylin and eosin (HE)-stained slides. The RCCs were classified according to the World Health Organization (WHO) classification of Tumours of $2002^{24}$. The protocol for DNA isolation and mutation analyses have been described previously ${ }^{23}$. Briefly, paraffin was removed with xylene and tumor DNA was extracted by salt-precipitation. The entire gene was amplified using 6 primer sets as described before ${ }^{23}$. Samples were first subjected to polymerase chain reaction-single-strand conformational polymorphism (PCR-SSCP) analysis, which was followed by direct sequencing in case of aberrant or unclear results. Mutations were identified by visual inspection of sequences provided by the ABI basecaller (Applied Biosystems, Nieuwerkerk a.d. IJssel, The Netherlands). After revision and $V H L$ gene mutation analyses, data was available for $235 \operatorname{cases}^{23}$.

\section{Questionnaire}

At baseline, all cohort members completed a mailed, self-administered questionnaire on dietary habits and other risk factors for cancer ${ }^{2 k}$. Participants were asked to report whether a physician had ever diagnosed 'high blood pressure' and at what age the diagnosis was made (in five year age groups from 'younger than 30 years', in 30-34 years" to " $65-69$ years'). Duration since diagnosis was calculated by subtracting the midpoint age in the age group of diagnosis from the age at baseline and was categorized into three broad categories: 0-9 years, $10-19$ years and $\geq 20$ years.

Participants were also asked to report on use of any drugs that they used longer than six months, for what condition and in what calendar period. All drugs were classified into therapeutic groups using the Anatomical Therapeutic Chemical (ATC) classification of the WHO Collaborative Centre for Drug Statistical Methodology ${ }^{26,27}$. 


\section{Data analysis}

Differences between cases with and without collected tumor material were assessed by calculating Student t-tests and chi-square tests. RRs for RCC were calculated for history of hypertension and use of antihypertensive medication. Case groups were defined as follows: total RCC (all histologically confirmed cases of RCC detected by linkage to cancer and pathology registries; $N=337$ ); clear-cell RCC (classified as clearcell RCC after pathological revision; $N=187$ ); mutated clear-cell RCC (clear-cell RCC with a mutation in the VHL gene; $\mathrm{N}=114$ ) and wildtype clear-cell RCC (clear-cell RCC without a mutation in the VHL gene; $\mathrm{N}=73$ ). Confounders considered were age at baseline (years), sex, current cigarette smoking (yes'no), cigarettes smoked (number/day), years of cigarette smoking (years), alcohol consumption ( $\mathrm{g} / \mathrm{day}$ ), body mass index (BMI; $\mathrm{kg} / \mathrm{m}^{2}$ ), a history of diabetes mellitus (yes/no), a history of RCC in first-grade family (yes/no), non-occupational physical activity $(<30,30-60,60-90,>90$ min/day), occupational physical activity for men only $(<8,8-12,>8 \mathrm{kj} / \mathrm{min})$ and social economic status (SES) based on education. Those variables that were associated with diagnosis of hypertension (and/or use of antihypertensive medication), that were an independent risk factor of $\mathrm{RCC}$ and that changed the risk estimates for the association of hypertension (and/or the use of antihypertensive medication) and RCC more than $10 \%$ were included as confounders in multivariable analyses. Using these criteria, confounders entered in the analyses were age, sex, BMI, current cigarette smoking, number of cigarettes smoked per day, and number of years of cigarette smoking.

RRs and corresponding 95\% confidence intervals (CI) for RCC were estimated using Cox proportional hazard models processed with the STATA statistical software package (STATA statistical software, Release 7, STATA Corporation, College Station, Texas, USA, 2001), after testing the proportional hazards assumption using scaled Schoenfeld residuals ${ }^{28}$. Standard errors were estimated using the robust Huber-White sandwich estimator to account for additional variance introduced by sampling persontime from the cohort ${ }^{29}$. To obtain $p$ values for dose-response trends, ordinal exposure variables were fitted as continuous terms.

\section{Results}

Hypertension was reported somewhat more frequently among RCC cases than subcohort members $(29.4 \%$ versus $26.3 \%$; Table 6.1$)$. RCC cases also reported a slightly higher use of antihypertensive medication than the subcohort members $(23.2 \%$ versus $21.1 \%$ ). RCC cases had a higher BMI, were more often current cigarette smokers and had been diagnosed less frequently with diabetes mellitus than subcohort members. When these variables were compared between patients with tumor material and patients without tumor material, no significant differences were observed. Only the percentage of antihypertensive medication use was significantly higher for cases with 
tumor tissue collected compared to cases for whom no tissue could be collected $(p=0.02)$.

Table 6.1 Description of exposure variables and potential confounders in subcohort members $(\mathrm{N}=4,774)$, $\mathrm{RCC}$ cases $(\mathrm{N}=337)$ and $\mathrm{RCC}$ cases with tissue blocks collected $(\mathrm{N}=235)$, The Netherlands Cohort Study on Diet and Cancer (NLCS), 1986-1997.

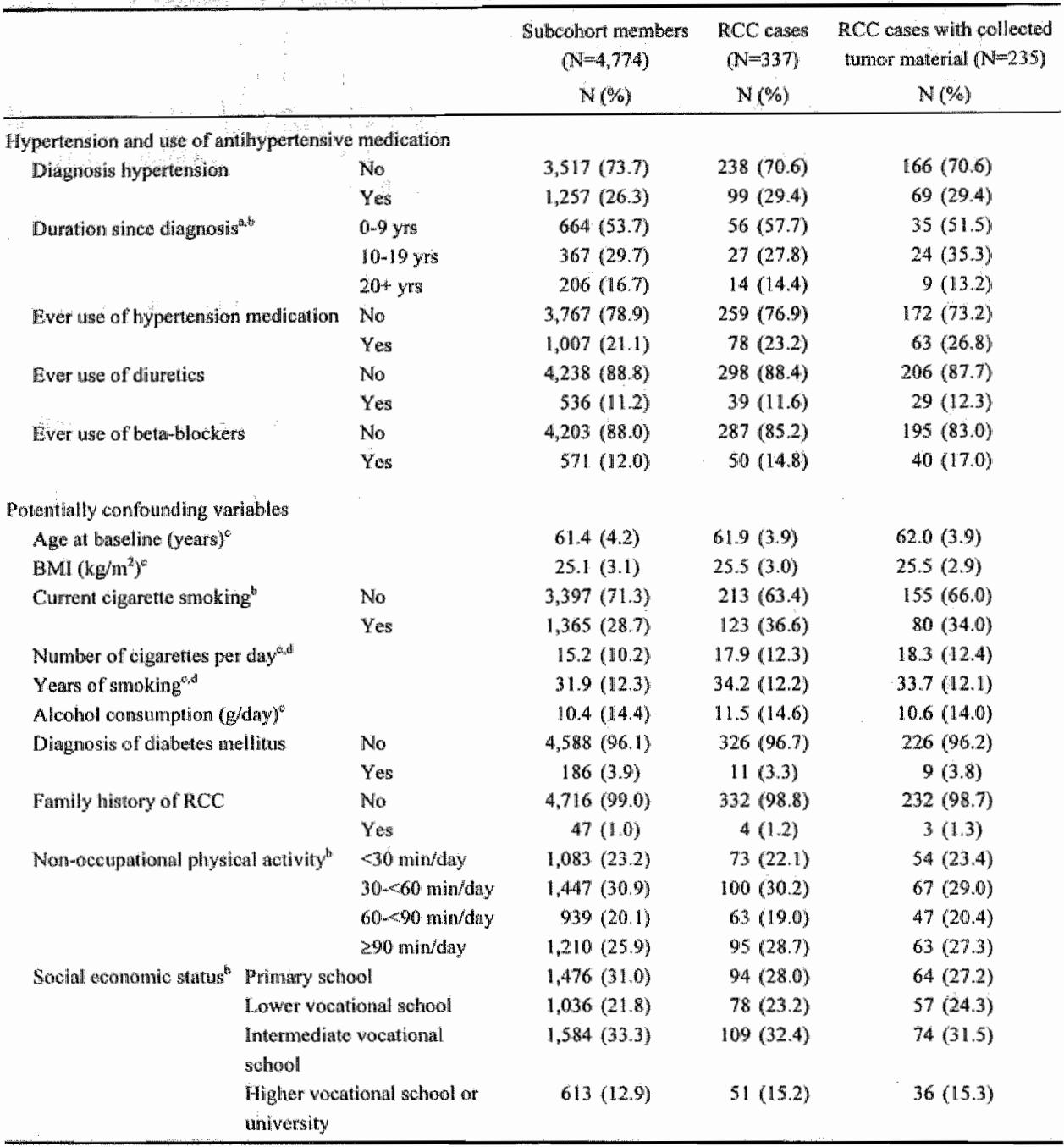

$\mathrm{RCC}=$ Renal cell carcinoma; BMIow Body Mass Index; "Only for persons who reported a diagnosis of hypertension; ${ }^{\circ}$ Due to missing walues totals do not add up to 4774,337 and 235 , respectively; " Mean (standard deviation); ${ }^{2}$ Only for ever-smokers

Cohort members who reported a history of hypertension or use of antihypertensive medication at baseline, had a slightly increased risk of RCC (rate ratio (RR): $1.22 ; 95 \%$ confidence interval $(95 \% \mathrm{CI}): 0.94-1.58$ and $1.14 ;(95 \% \mathrm{Cl}: 0.85-1.52)$, respectively 
(Table 6.2). These RRs (as all following RRs) were adjusted for sex, age, BMI and cigarette smoking. There was no difference between men and women with respect to the association between history of hypertension and RCC risk ( $p$ for interaction $=0.99$ ). A diagnosis of hypertension was associated with a RR of $1.21(95 \% \mathrm{Cl}: 0.87-1.69)$ in men and a RR of $1.21(95 \% \mathrm{CI}: 0.80-1.84)$ in women. The RR for use of antihypertensive medication was also nearly the same in men and women $(p$ for interaction $=0.92$ ). With an increasing time interval between diagnosis of hypertension and baseline, hypertension was associated with slightly decreasing risks of RCC, with RRs of $1.27 ; 1.16$ and 1.15 , for time intervals of less than 10 years, $10-19$ years, and 20 years or more, respectively.

Studying the interaction of the diagnosis of hypertension and antihypertensive medication use did not reveal divergent results. The RRs for use of diuretics or betablockers in cohort members, who had not reported a diagnosis of hypertension were relatively high, but the number of cases and person-years in the subcohort was small (Table 6.2).

Repeated analysis with exclusion of the first two years of follow-up did not alter the results considerably: RRs were slightly lower (data not shown).

Of the 235 patients for whom tissue specimens were available, 187 had a clear-cell RCC $(80 \%)$. In 114 patients with clear-cell RCC a mutation in the VHL gene was detected $(61 \%)$. The RR for diagnosis of hypertension was higher in cases with a $V H L$ mutation than in cases with VHL wildtype: RRs equalled 1.34 (95\% CI: 0.87-2.07) and 0.88 (95\% CI: $0.51-1.53$ ), respectively (Table 6.3 ). By contrast, the RR for use of antihypertensive medication was higher in cases with VHL wildtype (RR: 1.53 ; 95\% CI: 0.89-2.61). The RR for use of diuretics was statistically significantly increased in cases with $V H L$ wildtype (RR: $2.11 ; 95 \%$ CI: 1.16-3.83).

The RR was also increased in cohort members who used diuretics or beta-blockers and did not report a diagnosis of hypertension but numbers of cases and subcohort personyears were very small and the confidence intervals were wide. 
Trable 6.2 Ageadjusted and nultiwariable adjusted rate ratios (RR) for total RCC $(\mathrm{N}=337 \mathrm{7})$ according to hypertension and antihypertensive medication use; The Netherlands Cohort Study on Dier and Cancer (NLCS) 1986-1997.

\begin{tabular}{|c|c|c|c|c|c|c|}
\hline \multirow[b]{2}{*}{ variable } & \multicolumn{3}{|c|}{ Age- and sex-adjusted analyses } & \multicolumn{3}{|c|}{ Multivariable adjusted analyses } \\
\hline & $\begin{array}{l}\text { Nerses/ Person } \\
\text { years sulbcohort }\end{array}$ & $\mathbf{R R}^{\mathbf{a}}$ & $95 \% \mathrm{CI}$ & $\begin{array}{l}\text { Nassed Penson } \\
\text { years subcohort }\end{array}$ & $\mathrm{RR}^{\mathrm{b}}$ & $95 \% \mathrm{CI}$ \\
\hline \multicolumn{7}{|c|}{ Diagnosis of hyperterusion } \\
\hline No & $238 / 36,943$ & 1 & Ref & $210 / 33,554$ & il & Ref \\
\hline 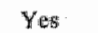 & $99 / 13,054$ & 1.24 & $0.97-1.59$ & $90 / 12 ; 097$ & 1.22 & $0.94-1.58$ \\
\hline
\end{tabular}

Time Hitarval befween dingmos is hypentension and baseline

\begin{tabular}{|c|c|c|c|c|c|c|}
\hline No didgnosis of hypertension & $238 / 36,943$ & 1 & Ref & $210 / 33,554$ & 1 & $\operatorname{Ref}$ \\
\hline 0.9 years & $56 / 6,918$ & 1.32 & $0.97-1.79$ & $51 / 6,365$ & 1.27 & $0.92 \times 1.76$ \\
\hline $10-19$ yeara & $27 / 3,753$ & 1.16 & $0.77-1.76$ & $24 / 3,459$ & 1.16 & $0.74-1.81$ \\
\hline 20.- years & $14 / 2,181$ & 1.06 & 0.611 .86 & $14 / 2,075$ & 1.15 & 0.6602 .03 \\
\hline$p$ for trend & & & 0.44 & & & 0.71 \\
\hline
\end{tabular}

Antitrypertensive medication use

\begin{tabular}{|c|c|c|c|c|c|c|}
\hline No & $259 / 39,787$ & 1 & Ref & $231 / 36,237$ & 1 & Ref \\
\hline Yest & $78: 10,210$ & 1.20 & $0.92-1.56$ & $69 / 9,415$ & 1.14 & $0.85-1.52$ \\
\hline \multicolumn{7}{|c|}{ Yuretic use } \\
\hline No & $298 / 44,55$ & 1 & Ref & $265 / 40,6449$ & 1 & Ref \\
\hline Yes: & $39 / 5,4444$ & 1.16 & $0.82-1.64$ & $35 / 5,0003$ & 1.14 & $0.79-1.66$ \\
\hline \multicolumn{7}{|c|}{ Aetil-blocker tuse } \\
\hline No & $287 / 44,157$ & 1 & Ref & $255 / 40,256$ & 1 & Ref \\
\hline Yes & $50 / 5.839$ & 1.30 & $0.94-1.78$ & $45 / 5,394$ & 1.27 & $0.90-1.78$ \\
\hline
\end{tabular}

Diagnosis of hypertension and antilimpertensive nedication use

\begin{tabular}{|c|c|c|c|c|c|c|}
\hline No Hyp/No Med & $219 / 34,310$ & 1 & Ref & $194 / 31,148$ & 1 & Ref \\
\hline No Hyp/Yes Med & $19 / 2,633$ & 1.06 & $0.65-1.73$ & $16 / 2,408$ & 0.95 & $0.56-1.64$ \\
\hline Yes: Hypha Med & $40 / 5,478$ & 3.19 & $0.83-1.68$ & $37 / 5,090$ & 1.16 & $0.80-1.68$ \\
\hline Yes Hyp/Yes Mad & $59 / 7,576$ & 1.29 & $0.95-1.75$ & $53 / 7,008$ & 11.25 & $0.91-1.74$ \\
\hline \multicolumn{7}{|c|}{ ingmos is of hypertension tund ditretic use } \\
\hline No Hyp/ No Meal & $230 / 36,155$ & 1 & Ref & $203 / 32,837$ & 1 & Ref \\
\hline No Iyp/Yos Med & $8 / 788$ & 1.69 & $0.80-3.57$ & $7 / 717$ & 1.54 & $0.68-3.46$ \\
\hline Yes Hyp No Med & $68 / 8,396$ & 1.32 & $0.99-1.75$ & $62 / 7,812$ & 1.28 & $0.95-1.73$ \\
\hline Yes Hyp/Yas Med & $31 / 4,657$ & 1.15 & $0.77 \times 1.64$ & $2,8 / 4,286$ & 1.15 & $0.76 \% 1.75$ \\
\hline \multicolumn{7}{|c|}{ angusis of hypertension and beta-blocker use } \\
\hline No Hypho Med & $222 / 35,348$ & 1 & Rof & $196 / 32,098$ & 1 & Reft \\
\hline No Hypryes Med & $16 / 1.595$ & 1.41 & $0.82-2.41$ & $14 / 1,456$ & 1.36 & $0.76 \cdot 2.44$ \\
\hline Yes lyp/No Med & $65 / 8,811$ & 11.23 & $0.92-1.64$ & $59 / 8,159$ & 1.21 & $0.89-1.64$ \\
\hline Yes lyp/Yes Med & $34 / 4,243$ & 1.33 & $0.91-1.95$ & $31 / 3,939$ & 1.31 & $0.87-1.96$ \\
\hline
\end{tabular}

$\mathrm{RCC}_{\mathrm{s}}$ renal cell carchoms: $\mathrm{RR}$, rate ration $\mathrm{Cl}$, confidence interval; Ref reference; " Rate ratio adjusted for age (years) and sex; "Ráte ratio adjusted for age (years), sex, body mass index ( $\left.\mathrm{kg} / \mathrm{m}^{2}\right)$, current cigarette smoking at baseline (yes wersws no), nuirmber of chgarettes smoked per day continuous) and years of cigarette smoking (continuous) 


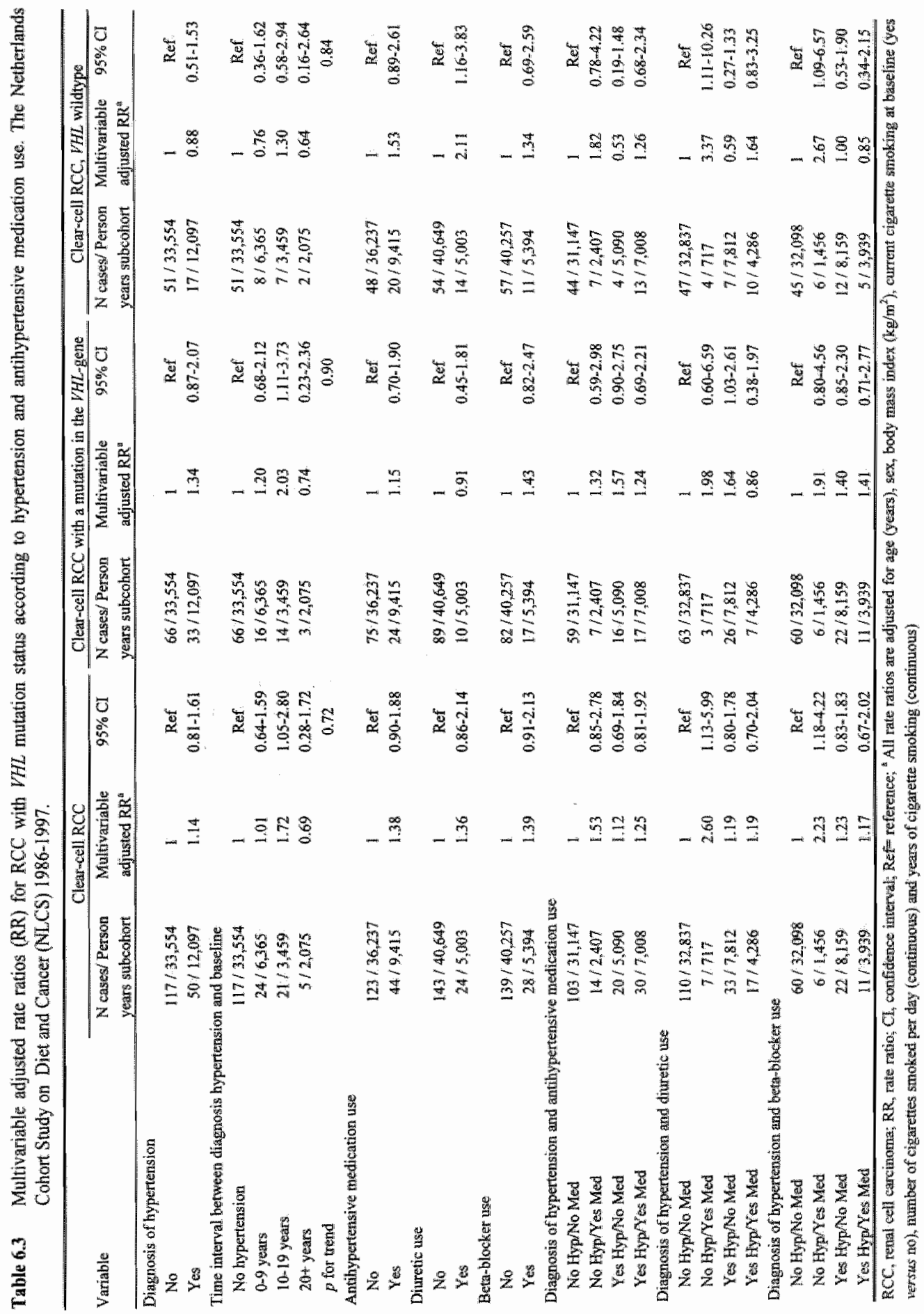




\section{Discussion}

In this study we observed that hypertension and use of antihypertensive medication were associated with a slightly increased, although statistically non-significant, risk of RCC. The association with hypertension was stronger in RCC patients with VHL mutations, while the association with use of antihypertensive medication was stronger in cases with $W H L$ wildtype. Diuretics were associated with an increased risk of clearcell RCC with $V H L$ wildtype.

These results from the NLCS are most likely not affected by selection or information bias. Selection bias is unlikely given the high level of follow-up in terms of cases and subcohort person-years ${ }^{22,30}$. In theory, selection bias may have occurred in the collection of tissue samples ${ }^{31}$. For 235 of the 337 cases $(70 \%)$, tumor material could be collected. There was no indication for bias in the selection of cases with tumor material according to the risk factors and potential confounders studied, except for the use of antihypertensive medication, which can be attributed most likely to chance. Information bias is unlikely in our study because the information with respect to the risk factors was collected before the diagnosis of RCC. Diagnosis of hypertension and use of antihypertensive medication were self-reported ${ }$ however, and misclassification of exposure is a potential source of bias. In two studies conducted in the United States moderate agreement between self-report and actual measurement of blood pressure was observed; estimates of sensitivity for self-reported hypertension were between $62 \%$ and $82 \%{ }^{32}$ and $71 \%$ in the NHANES III study ${ }^{33}$. In an American validation study sensitivity of recall for use of antihypertensive medication among controls was $86 \%$ after two years and $79 \%$ after eight years ${ }^{34}$. In a small validation study (207 subjects) within our cohort study, use of medication for the cardiovascular system was recalled correctly by $66 \%$ of the users ${ }^{26}$. The subgroup of cases and subcohort members that reported use of antihypertensive medication, without reporting a diagnosis of hypertension, may indicate misclassification. Examining the indications for medication reported by the participants in the questionnaire at baseline revealed that only $11 \%$ of the persons in this group reported that the medication was used because of hypertension, suggesting that misclassification is limited. The misclassification of self-reported hypertension and use of antihypertensive medication is expected to be non-differential, attenuating the rate ratios towards one.

In a meta-analysis ${ }^{2}$ based on 13 case-control studies a pooled adjusted odds ratio of 1.75 (95\% Cl: 1.61-1.90) was calculated for the association between hypertension and RCC. This pooled odds ratio did not include results from prospective cohort studies. Four prospective cohort studies measured blood pressure at baseline and followed the cohort members for the occurrence of $\mathrm{RCC}^{5,6,9,10}$. All studies found increased risks of RCC with increasing blood pressure. The outcomes of these studies are difficult to compare with our study, because of the different exposure measurement. Three prospective cohort studies used self-reported diagnosis of hypertension to define the exposure $^{8,11,12}$ and show therefore the highest resemblance with our study design. Two 
of these studies reported increased RRs for diagmosis of hypertension and RCC risk ${ }^{11,12}$. These studies were relatively small, however, with 14 and $62 \mathrm{RCC}$ cases, respectively. The Cancer Prevention Study $\mathrm{II}^{8}$ included 1.2 million subjects and $335 \mathrm{RCC}$ deaths after seven years of follow-up. Self-reported diagnosis of hypertension was associated with RCC deaths in females (RR: $2.2 ; 95 \%$ CI: 1.5-3.2), but not in males (RR: 1.1; $95 \% \mathrm{CI}: 0.9-1.5)^{8}$. The RRs for hypertension observed in the current study are lower than the pooled odds ratio for case-control studies ${ }^{2}$, but our estimates point in the same direction. Also, several other studies have published RRs comparable to ours, especially for males ${ }^{4,8,35-37}$.

In another meta-analysis a pooled odds ratio was calculated for use of diuretics and risk of $\mathrm{RCC}^{\sharp}$. Based on nine case-control studies an average odds ratio was calculated of 1.55 (95\% Cl: $1.42-1.71$ ). Some of the included studies used self-report, while others used medical files or data from a pharmacy database ${ }^{4,36,38,39}$. Three prospective cohort studies also showed an increased risk for use of diuretics, with an exception for males in the Cancer Prevention Study $\mathbb{I I}^{7,8,11}$.

Hypertension may be a possible cause, but it may also be an early symptom of $\mathrm{RCC}^{40}$. The increased risk of hypertension may therefore reflect detection bias. Whether this bias is present may be evaluated by excluding cases from the analysis that were detected shortly after baseline measurement, or by investigating the relative risks according to time interval between diagnosis of hypertension and baseline. In our study, relative risks were slightly lower after exclusion of cases in the first two years of follow-up, and duration between diagnosis of hypertension and baseline was associated with slightly decreasing risks estimates. In a Danish record-linkage study a U-shaped pattern was observed with highest risks for the shortest and the longest time interval. Other studies did not observe a modification of the risk estimates according to time interval $1^{4,10,38,41,42}$.

Despite the large number of epidemiological studies, there is little convincing evidence with respect to the biological mechanism between hypertension or use of antihypertensive medication and the development of RCC. Gago-Dominguez et al. ${ }^{18}$ suggested that lipid peroxidation, which is increased in obese and hypertensive individuals, might be responsible - at least in part - for the increased risk of RCC. Byproducts of lipid peroxidation have been shown to react with renal DNA to form adducts $^{18}$. Diuretic therapy might be carcinogenic through conversion in the stomach to carcinogenic nitroso derivates or through a low-grade carcinogenic effect on the renal tubular cell, its principal target'.

In our study, we also investigated whether hypertension and/or use of antihypertensive medication were associated with mutational status of the VHL gene. The VHL gene is a tumor suppressor gene. Loss of function is an early event in most cases of clear-cell $\mathrm{RCC}$, by mutation or methylation of the promoter region. When hypertension and/or use of antihypertensive drugs are related to RCC risk, it is conceivable that these risk factors are associated with specific subtypes of RCC, e.g. clear-cell RCC with mutations in the VHL gene. In our analysis somewhat higher risks were found for 
hypertension in relation to the risk of clear-cell RCC with a mutation in the VHL gene, and slightly decreased risks in cases with VHL wildtype. For use of antihypertensive medication and especially diuretic treatment, we observed the opposite; RRs were increased in cases with VHL wildtype and only slightly increased in cases with mutations in the VHL gene. It is possible that diagnosis of hypertension and use of diuretics and risk of clear-cell RCC work through different pathways (through a mutation in the $V H L$ gene or not). However, false-positive findings because of multiple testing and small numbers cannot be excluded.

This is the first study to evaluate the association of hypertension and/or use of antihypertensive medication with mutations in the $V H L$ gene. Without a specific $a$ priori hypothesis it is difficult to exclude chance findings, especially with the small numbers in the sub-analyses. The findings with respect to the possible association with the VHL gene need to be confirmed in future studies.

\section{Acknowledgements}

We are indebted to the participants of this study and further wish to thank the cancer registries (IKA, IKL, IKMNN, IKN, IKO, IKR, IKST, IKW, IKZ and VIKC), the Netherlands nationwide registry of pathology (PALGA) and the pathology laboratories for providing the tissue samples (for a complete list $\operatorname{see}^{23}$ ). We also thank Dr. E. Dorant, C.A. de Brouwer, prof.dr. A. Geurts van Kessel and prof.dr. D.J. Ruiter for their preparatory work for this study; K.P. van Houwelingen and H. Gorissen for the laboratory analysis, Dr. A. Volovics and Dr. A. Kester for statistical advice; S. van de Crommert, H. Brants, J. Nelissen, C. de Zwart, M. Moll, W. van Dijk, M. Jansen, and A. Pisters for assistance; and H. van Montfort, T. van Moergastel, L. van den Bosch, and R. Schmeitz for programming assistance. 


\section{References}

1. Grossman $\mathrm{E}$, Messerli $\mathbf{F H}$, Goldbourt U. Does diuretic therapy increase the risk of renal cell carcinoma? [editorial][see comments]. Am I Cardiol 1999;83:1090-3.

2. Grossman E, Messerli FH, Boyko V, Goldbourt U. Is there an association between hypertension and cancer mortality? Am J Med 2002; 1 12:479-86.

3. McLaughlin JK, Chow WH, Mandel JS, et al. International renal-cell cancer study. VIII. Role of diuretics, other anti-bypertensive medications and hypertension. Int J Cancer $1995 ; 63: 216-21$.

4. Shapiro JA, Williams MA, Weiss NS, Stergachis A, LaCroix AZ, Barlow WE. Hypertension, antihypertensive medication use, and risk of renal cell carcinoma. Am y Epidemiol 1999;149:521-30.

5. Chow WH, Gridley G, Fraumeni JF, Jr., Jarvholm B. Obesity, hypertension, and the risk of kidney cancer in men. N Engl I Med 2000;343:1305-11.

6. Rosengren A, Himmelmann A, Wilhelmsen L, Branehog I, Wedel H. Hypertension and long-term cancer incidence and mortality among Swedish men. J Hypertens 1998 ; 16:93340 .

7. Mellemgaard A, Moller H, Olsen JH. Diuretics may increase risk of renal cell carcinoma. Cancer Causes Control 1992;3:309-12.

8. Heath CW Jr., Lally CA, Calle EE, McLaughlin JK, Thun M.I. Hypertension, diuretics, and antihypertensiwe medications as possible risk factors for renal cell cancer. Am J Epidemiol 1997;1:45:607-13.

9. Grove JS, Nomura A, Severson RK, Stemmermann GN. The association of blood pressure with cancer incidence in a prospective study. Am J Epidemiol 1991;134:942-7.

10. Coughlin SS, Neaton JD, Randall B, Sengupta A. Predictors of mortality from kidney cancer in 332,547 men screened for the Multiple Risk Factor Intervention. Trial. Cancer $1997 ; 79: 2171-7$.

11. Prineas RJ, Folsom AR, Zhang ZM, Sellers TA, Potter J. Nutrition and other risk factors for renal cell carcinoma in postmenopausal women. Epidemiology 1997;8:31-6.

12. Fraser GE, Phillips RL, Beeson WL. Hypertension, antihypertensive medication and risk of renal carcinoma in California Seventh-Day Adventists. Int J Epidemiol 1990;19:832-8.

13. Kovacs $G$, Akhtar $M$, Beckwith $B J$, et al. The Heidelberg classification of renal cell tumours [editoriall]. J Pathol 1997; 183:131-3.

14. Gnarra JR, Tory $\mathrm{K}$, Weng $\mathrm{Y}$, et al. Mutations of the VHL tumour suppressor gene in renal carcinoma. Nat Genet 1994:7:85-90.

15. Cohen HT. Advances in the molecular basis of renal neoplasia. Curr Opin Nephrol Hy $1999 ; 8: 325-31$.

16. Brauch $\mathrm{H}$, Weirich $\mathrm{G}$, Hornauer MA, Storkel $\mathrm{S}$, Wohl $\mathrm{T}$, Bruning $\mathrm{T}$. Trichloroethylene exposure and specific somatic mutations in patients with renal cell carcinoma. I Natll Cancer Inst 1999;91:854-61.

17. Hemminki $\mathrm{K}$, Jiang $\mathrm{Y}$, Ma X, Yang K, Egevad L, Lindblad P. Molecular epidemiology of VHL gene mutations in renal cell carcinoma patients: relation to dietary and other factors. Carcinogenesis $2002 ; 23 ; 809-15$.

18. Gago-Dominguez M, Castelao JE, Yuan JM, Ross RK, Yu MC. Lipid peroxidation: a nowel and unifying concept of the etiology of renal cell carcinoma (United States). Cancer Causes Control 2002;13:287-93.

19. Van den Brandt PA, Goldbohm RA, Van 't Veer P, Volovics A, Hermus RJ, Sturmans $F$. A large-scale prospective cohort study on diet and cancer in The Netherlands. I Clin Epidemiol 1990;43:285-95. 
20. Volovics $A$, van den Brandt PA. Methods for the analyses of case-cohort studies. Biom I $1997 ; 39: 159-214$.

21. Van den Brandt PA, Schouten LJ, Goldbohm RA, Dorant E, Hunen PM. Development of a record linkage protocol for use in the Dutch Cancer Registry for Epidemiological Research. Int J Epidemial 1990;19:553-8.

22. Goldbohm RA, Van den Brandt PA, Dorant E. Estimation of the coverage of Dutch municipalities by cancer registries and PALGA based on hospital discharge data. Tijdschr Soc Gezondheidsz 1994;72:80-4.

23. van Houwelingen $\mathrm{KP}$, van Dijk BAC, Hulsbergen-van de Kaa CA, et al. Prevalence of Von Hippel-Lindau gene mutations in sporadic Renal Cell Carcinoma: results from the Netherlands Cohort Study. BMC Cancer 2005;5:57.

24. Eble J, Sauter $G$, Epstein $J_{\text {s }}$ Sesterhenn $I$. World Health Organization Classification of Tumours. Pathology and Genetics. Tumours of the Urinary System and Male Genital Organs. Lyon: LARC Press, 2004.

25. Goldbohm RA, van den Brandt PA, Brants HA, et al. Validation of a dietary questionnaire used in a large-scale prospective cohort study on diet and cancer. Eur J Clin Nutr $1994,48253-65$.

26. Van den Brandt PA, Petri H, Dorant E, Goldbohm RA, Van de Crommert S. Comparison of questionnaire information and pharmacy data on drug use. Pharm Weekbl [Sci] $1991 ; 13: 91-6$.

27. Anonymous. About the ATC/DDD system. WHO Collaborating Centre for Drug Statistics Methodology, 2004.

28. Schoenfeld D. Partial residuals for the proportional hazards regression model. Biometrika 1982;69:239-41.

29. Lin DY, Wei LJ. The robust inference for the Cox Proportional Hazards Model. J A.m Stat Assoc 1989;84:1074-8.

30. van den Brandt PA, van't Veer P, Goldbohm RA, et al. A prospective cohort study on dietary fat and the risk of postmenopausal breast cancer. Cancer Res 1993;53:75-82.

31. Hoppin JA, Tolbert PE, Taylor JA, Schroeder JC, Holly EA. Potential for selection bias with tumor tissue retrieval in molecular epidemiology studies. Ann Epidemiol 2002;12:1-6.

32. Giles WH, Croft JB, Keenan NL, Lane MJ, Wheeler FC. The validity of self-reported hypertension and correlates of hypertension awareness among blacks and whites within the stroke belt. Am J Prev Med 1995;11:163-9.

33. Vargas CM, Burt VL, Gillum RF, Pamuk BR. Validity of self-reported hypertension in the National Health and Nutrition Examination Survey III, 1988-1991. Prev Med 1997;26: $678-85$.

34. Boudreau DM, Daling JR, Malone KE, Gardner IS, Blough DK, Heckbert SR. A validation study of patient interview data and pharmacy records for antihypertensive, statin, and antidepressant medication use among older women. Am J Epidemiol 2004;159:308-17.

35. Kreiger $N$, Marrett $L D$, Dodds $L$, Hilditch $S$, Darlington GA. Risk factors for renal cell carcinoma: results of a population-based case-control study. Cancer Causes Control $1993 ; 4: 101-10$.

36. Weinmann S, Glass AG, Weiss NS, Psaty BM, Siscovick DS, White E. Use of diuretics and other antihypertensive medications in relation to the risk of renal cell cancer. Am J Epidemiol 1994;140;792-804.

37. Chow WH, McLaughlin JK, Mandel JS, Wacholder $S$, Niwa S, Fraumeni JF, Jr. Risk of renal cell cancer in relation to diuretics, antihypertensive drugs, and hypertension. Cancer Epidemiol Bionarkers Prev 1995;4:327-31. 
38. Finkle WD, MclLaughlin JK, Rasgon SA, Yeoh HH, Low JE. Increased risk of renal cell cancer among women using diuretics in the United States. Cancer Causes Control $1993 ; 4: 555-8$.

39. Hiatt RA, Tolan K, Quesenberry CP, Jr. Renal cell carcinoma and thiazide use: a historical, case-control. study (Callformia, USA). Cancer Causes Control 1994;5:319-25.

40. Novick AC, Campbell SC. 75. Renal tumors. In: Walsh PC, Retik AB, Darracott Vaughan Jr E, et al, eds. Campbell's Urology, eighth ed. Philadelphia: Saunders, 2002:2672-719.

41. Yuan JM, Castelao JE, Gago Dominguez M, Ross RK, Yu MC. Hypertension, obesity and their medications in relation to renal cell carcinoma. Br J Cancer 1998;77:1508-13.

42. Rosenberg $L$, Rao RS, Palmer $J R_{\text {, }}$ et al. Calcium channel blockers and the risk of cancer. JAMA 1998;279:1000-4. 


\section{7}

Carotenoid and vitamin intake, von HippelLindau gene mutations and sporadic renal cell carcinoma: results from the Netherlands cohort study

Boukje A.C. van Dijk Leo J. Schouten Egbert Oosterwijk Christina A. Hulsbergen-van de Kaa Lambertus A.L.M. Kiemeney R. Alexandra Goldbohm Jack A. Schalken Piet A. van den Brandt 


\section{Abstract}

\section{Background}

Carotenoids and vitamins may prevent cancer from occurring because of their antioxidant capacties. Von Hippel-Lindau (VHL) gene mutations are considered a primary event in the carcinogenesis of clear-cell renal cell carcinoma (RCC).

\section{Objective}

We investigated whether dietary carotenoid and vitamin intake and supplemental vitamin use were associated with RCC risk and with mutations in the YHL gene in clear-cell RCC.

\section{Dessign}

The Netherlands Cohort Study on diet and cancer (NLCS) includes 120,852 persons, who completed a selfadministered food-frequency questionnaire in 1986. After 11.3 years of follow-up, 314 cases and a tandom sample of 4.438 persons (subeohort) with complete dietary data were used in a case-cohort approach. WHL gene mutational analys is was complete for 225 cases. Rate ratios (RRs) and corresponding $95 \%$ confidence intervals were estimated using Cox proportional hazard models, while adjusting for age, sex, smoking, body mass index and a history of lypertension.

\section{Reswits}

We observed no association for dietary carotenoid and vitamin intake and RCC risk. We observed a somewhat increased risk with supplemental vitamin $\mathrm{E}, \mathrm{AD}$, and multivitamin use. Results were suggestive of ligher RRs for alpha-carotene, beta-cryptoxanthin, folate, and supplemental vitamin $\mathrm{C}$ and multivitamin intake for wildtype WHL thmors.

\section{Conchusions}

There was no association of carotenoid, vitamin or supplemental vitamin intake and RCC risk. Some results were suggestive for a differential effect between VHL wildtype and VHL mutated tumors. These associations should be investigated by others to confirm the current observations. 


\section{Introduction}

Renal Cell Carcinoma (RCC) is the ninth most common tumor in the European Union'. Both the incidence and mortality rates are about twice as high for males than females ${ }^{\mathrm{i}}$. The 5-year survival is approximately $55 \%{ }^{2}$.

Mutations in the von Hippel-Lindau (VHL) gene are believed to be an early event in renal carcinogenesis. VHL mutations are mainly observed in tumors of the most common histological subtype, i.e. clear-cell $\mathrm{RCC}^{3}$. Mutations are observed in the entire gene and usually lead to a truncated inactive protein ${ }^{3}$. The $V H L$ gene is a tumor suppressor gene involved in cell cycle regulation, regulation of hypoxia inducible genes and proper fibronectin assembly in extracellular matrix ${ }^{4,5}$. It is estimated that $56 \%$ to $69 \%$ of clear-cell renal tumors harbor a mutation in the $V H L$ gene.

Occupational exposure to trichloroethylene ${ }^{6,7}$ and consumption of citrus fruit and vegetables (confined to smokers) ${ }^{8}$ have been linked to $V H L$ gene mutations in renal cell carcinoma $(\mathrm{RCC})$ in previous studies ${ }^{6-8}$. There is some evidence that the intake of vegetables, selenium and particularly citrus fruit protects the renal WHL gene from mutational insults, although chance results could not be ruled out ${ }^{8}$. To our knowledge, there are no other reports on an association of fruits and vegetables, or the more specific carotenoids and vitamin intake, and $V H L$ gene mutations published thus far.

Generally, intake of carotenoids and vitamins are considered to be protective of cancer, mainly due to their ascribed anti-oxidant capacities". In a study by Nyberg et al. diet and smoking habits were linked to somatic mutations in vivo ${ }^{10}$. The mutant frequency was significantly decreased in relation to vitamin $\mathrm{C}$ intake, while a u-shaped association with higher mutation frequencies at lower and higher intakes was observed with dietary carotenoid intake ${ }^{19}$. Dietary antioxidants take part in cellular reductionoxidation (redox) reactions in which they can act as either antioxidants (electron donors) or prooxidants (electron acceptors), depending on the physiological environment and general oxidative state ${ }^{11}$. Thus, the possibility exists that; in an environment resulting in prooxidant activity by dietary antioxidants, antioxidant supplementation may actually cause harm in terms of increased risk of new disease ${ }^{\prime \prime}$.

A limited number of epidemiological studies investigated the association of carotenoids and vitamins and risk of $\mathrm{RCC}^{12-21}$. Null associations have been observed for vitamin $\mathrm{A}$ intake ${ }^{13,15,16,21}$, inverse associations ${ }^{15,20,21}$ but also null associations for carotenoids ${ }^{13,16}$, inverse associations for vitamin $\mathrm{C}$ intake $\mathrm{e}^{15,20}$ and nul1 ${ }^{16}$ and inverse ${ }^{13}$ associations for vitamin $E$ intake. A reduced risk was observed for vitamin $\mathbb{E}^{14}$ and multivitamin supplementation ${ }^{13}$, while no protective effect was shown for beta-carotene supplementation $^{12}$.

We investigated whether dietary carotenoid (alpha-carotene, beta-carotene, Jutein+zeaxanthine, beta-cryptoxanthine, and lycopene), and vitamin (vitamins $A$ (retinol), $\mathrm{C}, \mathrm{E}$ and folate) intake and supplemental vitamin $\mathrm{C}, \mathrm{E}, \mathrm{AD}$, and multivitamin use were associated with sporadic RCC and, more specifically, with VHL gene mutations in clear-cell RCC in a prospective cohort study. Stratified analyses by 
smoking were also carried out since a differential effect by smoking status has been suggested for the association of citrus fruits and RCC and VHL gene mutations, and for the association of some carotenoids and vitamins and $\mathrm{RCC}^{16}$.

\section{Subjects and methods}

\section{Netherlands Cohort Study}

The Netherlands Cohort Study on diet and cancer (NLCS) started in September 1986. The study design has been reported in detail elsewhere ${ }^{22}$. Briefly, the cohort included 120,852 men and women aged 55-69 years in 1986. The study was designed as a casecohort study, using all cases and a random sample of 5,000 persons from the cohort (subcohort), who have been followed for vital status information to estimate the accumulated person-years in the entire cohort ${ }^{23}$.

\section{Follow-up for incident cancers and vital status}

The entire cohort was followed for incident cancer by computerized record linkage with the Netherlands Cancer Registry and PALGA, a national database of pathology reports. All participants who reported prevalent cancer (excluding skin cancer) at baseline were excluded from analyses (leaving 4,774 subcohort members). The method of record linkage to obtain information on cancer incidence has been described previously ${ }^{24}$. The completeness of cancer follow-up was estimated to be more than $96 \%{ }^{25}$. From 1986 to 1997 (11.3 years follow up) 355 kidney cancer cases (ICD-O-3: C64.9) were identified. Urothelial cell carcinomas were excluded and only histologically confirmed epithelial cancers were included (ICD-O: M8010-8119, 81408570 ), leaving 337 cases.

The subcohort has been followed up for vital status information biennially by mail. The vital status of subcohort members who did not respond, was completed by contacting municipal population registries. Only two male subcohort members were lost to followup after 11.3 years of follow-up.

\section{Questionnaire}

At baseline, all cohort members completed a mailed, self-administered questionnaire on dietary habits, lifestyle, smoking, personal and family history of cancer and demographic data ${ }^{26}$. The questionnaire concentrated on the habitual consumption of food and beverages during the year preceding the start of the study. The dietary section of the questionnaire was a 150 -item semi-quantitative food-frequency questionnaire, which was validated against 3-day diaries completed at three time points during a calendar $y \mathrm{ear}^{26}$. The correlation, adjusted for error index and day to day variation, between the record and the questionnaire was estimated at 0.76 for vitamin $\mathrm{A}$ intake and at 0.58 for vitamin $\mathrm{C}$ intake $\mathrm{e}^{26}$. 
Mean daily nutrient intakes were calculated using the computerized Dutch food composition table ${ }^{27}$. For calculation of the intake of specific carotenoids, an additionall food composition table has been constructed ${ }^{28}$, providing information on alphacarotene, beta-carotene, lutein+zeaxanthine, beta-cryptoxanthine and lycopene. Briefly, foods that are the main sources of carotenoids (e.g., vegetables) and some other foods were sampled and analyzed for alpha-carotene, beta-carotene, lutein, zeaxanthin, and lycopene. Values for all other foods were mostly derived from recent literature with the same methods of analysis used. In the carotenoid food composition table, lutein and zeaxanthin had to be taken together because most of the literature sources did not provide separate values for each of these carotenoids ${ }^{28}$. Folate data were derived from a validated liquid chromatography trienzyme method ${ }^{29}$, used to analyze the 125 most important Dutch foods contributing to folate intake ${ }^{30}$.

Information on supplement use was collected with an open-ended question with space for four different supplements at most. Participants were asked whether they used vitamin tablets, drops, or other preparations during the 5 years before baseline ${ }^{31}$. The relative validity of this open-ended question was studied in comparison to reference information from three personal interviews carried out within a period of 10 months ${ }^{32}$; recall for overall vitamin supplement use was $72.7 \%{ }^{32}$. In that study vitamin supplement use included vitamin $\mathrm{A}, \mathrm{C}, \mathrm{AD}, \mathrm{B1}, \mathrm{B} 2, \mathrm{~B} 6, \mathrm{~B} 12, \mathrm{~B}$ complex, $\mathrm{E}$ and multivitamin intake. In the current study, we investigated supplemental vitamin C, E, A and/or $\mathrm{D}(\mathrm{AD})$ and multivitamin intake.

According to criteria published before ${ }^{26}$, subjects with incomplete or inconsistent dietary data were excluded; 314 RCC cases and 4,438 subcohort members remained for anallyses.

\section{VHL gene mutation analysis}

Paraffin material of cancer cases was collected after approval by the Medical Ethical Committees of Maastricht University, PALGA and the Netherlands cancer registry. We were able to collect paraffin blocks of tumors for 251 cases from 51 pathology laboratories, which we described in detail elsewhere ${ }^{33}$.

One experienced pathologist (CAHK) revised all HE-stained slides. The RCC were classified according to the World Health Organization (WHO) classification of Tumours of $2002^{34}$. DNA isolation and mutation analyses have been described previously. Briefly, paraffin was removed with $x y l e n e$ and DNA was extracted by saltprecipitation. The entire gene was amplified using 6 primer sets. Samples were first subjected to PCR-SSCP analysis, which was followed by direct sequencing in case of aberrant or equivocal results. Mutations were identified by visual inspection of sequences provided by the $\mathrm{ABI}$ basecaller. After revision and $V H L$ gene mutation analyses, data was available for $235 \mathrm{cases}^{33}$. Information for 10 cases was discarded, since the dietary data for these subjects was incomplete or inconsistent. 


\section{Statistical analysis}

Based on the literature and previous analyses, considered confounders were age at baseline (years), sex, body mass index $\left(\mathrm{kg} / \mathrm{m}^{2}\right)$, a history of hypertension (yes/no), a family history of RCC (yes/no), alcohol consumption (g/day), social economic status (SES) based on education, non-occupational physical activity $(<30,30-60,60-90,>90$ min/day), occupational physical activity (for men only) $(<8,8-12,>12 \mathrm{kj} / \mathrm{min})$, and energy intake (kcal/day). Those variables that were associated with RCC and were correlated with one of the carotenoids or vitamins were included as covariates in multivariable analyses. Confounders entered in these multivariable analyses were age, sex, smoking, BMI and a history of hypertension.

Differences in age, sex, smoking status, BMI and a history of hypertension between cases with $(\mathrm{N}=225)$ and without $(\mathrm{N}=89)$ collected tumor material were assessed by calculating student $t$-tests and chi-square tests.

RRs were calculated for the dietary intake of carotenoids alpha-carotene, beta-carotene, luteintzeaxanthine, beta-cryptoxanthine and lycopene, and of the vitamins A (retinol), $\mathrm{C}, \mathrm{E}$ and folate. Exposure variables were categorized into quintiles based on the distribution in the subcohort, for men and women separately. For vitamin $\mathrm{C}$, however, quintiles 2 and 3 and quintiles 4 and 5 were combined, because the validation study demonstrated that these quintiles could not be distinguished ${ }^{26}$. Furthermore, we investigated use of supplemental vitamin $\mathrm{C}, \mathrm{E}, \mathrm{AD}$ and multivitamins (yes or no).

Analyses were carried out for the following case groups: total RCC (all cases of RCC detected by linkage to cancer and pathology registry; $\mathrm{N}=314$ ); clear-cell RCC (all cases of RCC classified as clear-cell after revision by one experienced pathologist (CAHK); $\mathrm{N}=179$ ); $V H L$ mutated clear-cell RCC (clear-cell RCC with a mutation in the VHL gene; $\mathrm{N}=110$ ) and $V H L$ wildtype clear-cell RCC (clear-cell RCC without a mutation in the $V H L$ gene; $N=69$ ).

RRs and corresponding 95\% confidence intervals (CD) were estimated using Cox proportional hazard models processed with STATA (STATA statistical software, Release 7, STATA Corporation, College Station, TX, USA, 2001), after testing the proportional hazards assumption using scaled Schoenfeld residuals ${ }^{35}$. Standard errors were estimated using the robust Huber-White sandwich estimator to account for additional variance introduced by sampling from the cohort ${ }^{36}$. To obtain $p$ values for dose-response trends, ordinal exposure variables were fitted as continuous terms. Two sided $p$ values are reported throughout this paper.

\section{Results}

Baseline characteristics for exposure variables and potential confounders for subcohort members, all cases, cases with collected tumor material, clear-cell cases and clear-cell cases with or without a VHL gene mutation are shown in table 7.1. First, we checked for differences in characteristics of RCC cases for whom we could $(\mathrm{N}=225)$ or could 
not $(\mathrm{N}=89)$ collect tumor tissue. There were no differences in mean age $(p=0.62)$, the percentage of men $(p=0.16)$, the percentage of smokers (never, ex and current) $(p=0.33)$, mean BMI $(p=0.85)$, or the percentage of cases that reported a history of hypertension $(p=0.71)$.

We also tested differences in mean carotenoid and vitamin intake and in the percentage of supplement users between clear-cell RCC with and without a $V H L$ gene mutation. There were no remarkable differences in mean carotenoid and vitamin intake between clear-cell RCC with and clear-cell RCC without a VHL gene mutation (results not shown). The percentage of supplemental vitamin $\mathrm{C}$ and multivitamin users was higher for clear-cell RCC with wildtype $V H L$ compared to clear-cell RCC with a $V H L$ gene mutation. $(10.1 \%$ versus $4.6 \%(p=0.15)$ and $10.1 \%$ versus $3.6 \%(p=0.08)$, respectively), although these differences were statistically not significant.

RRs for the association of carotenoids, vitamins, and supplement use and total RCC, clear-cell RCC and clear-cell RCC with or without $V H L$ gene mutations are shown in table 2. A statistically significant inverse association with RCC was observed in quintile 2 of lutein+zeaxanthin intake. Furthermore, a statistically significant increased risk of RCC was observed in quintile 4 of beta-cryptoxanthin intake. Eyeballing these results, we observed a possible u-shaped association of carotenoids and RCC risk, with the exception of beta-cryptoxanthin and lycopene. Higher intakes of beta-cryptoxanthin and lycopene were associated with an increased RCC risk. The possible u-shaped association was no longer present when investigating the association of carotenoids and clear-cell RCC risk. The observed RRs for wildtype $V H L$ tumors were higher than those observed for VHL mutated tumors in case of dietary alpha-carotene and betacryptoxanthin intake (table 7.2). Vitamin intake did not seem to be associated with RCC risk, but there was a possible differential effect for folate intake between tumors with and without a $V H L$ gene mutation. RRs were mostly greater than 1 in case of wildtype $V H L$ tumors, while these were mostly lower than I for $V H L$ mutated tumors. Supplemental vitamin E, AD and multivitamin use were associated with increased RCC risk, while there was no association of supplemental vitamin $C$ use and $R C C$ risk. Stratified analyses based on VHL mutational status revealed higher RRs for wildtype tumors in case of supplemental vitamin $\mathrm{C}$ and multivitamin use and lower RRs for wildtype tumors in case of supplemental vitamin $\mathrm{E}$ and $\mathrm{AD}$ use. Supplemental multivitamin use was associated with a statistically significant increased risk or clearcell tumors without a $V H L$ gene mutation (RR: $2.51 ; 95 \% \mathrm{CI}: 1.10-5.75$ ). 
Table 7.1 Descriptives for carotenoids, vatamins, supplement use and confounding factors for subcohort members and case groups. Netherlands cohort sudy on diet and cancer, 1986-1997.

\begin{tabular}{|c|c|c|c|c|c|c|}
\hline & Subcolhort & $\mathrm{RCC} \cdot \mathrm{lotal}$ & $\begin{array}{l}\text { Tumor } \\
\text { material } \\
\text { collected }\end{array}$ & $\begin{array}{l}\text { Chearell } \\
\mathrm{RCC}\end{array}$ & $\begin{array}{l}\text { Clearicell } \\
\text { RCG } M H L \\
\text { mutated }\end{array}$ & $\begin{array}{l}\text { Clear-cell } \\
\mathrm{RCC} \\
\text { Whidype } \\
\text { WHL }\end{array}$ \\
\hline & $N=4.438:$ & $N=314$ & $N=225$ & $x=-179$ & $\mathbb{N}=110$ & $\mathrm{~N}=69$ \\
\hline \multicolumn{7}{|l|}{ Carotenoids } \\
\hline Aphawcarotene (mug/day) - Mean (sd) & $0.696(0.569)$ & $0.685(0.499)$ & $0.666(0.444)$ & $0.676(6.462)$ & $0.674 \cdot(0.478)$ & $0.680(0.4399)$ \\
\hline Beta-carotene (tang/day) - Mean (sd) & $2.96(1.57)$ & $2.97(1.44)$ & $2.911(1.24)$ & $2.94(1.30)$ & $2.94(1.36)$ & $2.93(1.25)$ \\
\hline Lutentit Zeax anthin (ng/day) - Mean (so) & $2.56(1.13)$ & $2.56(1-11)$ & $2.50(1.03)$ & $2.52(1.05)$ & $2.57(1.11)$ & $2.44(0.94)$ \\
\hline Beta-cryptoxanthir (mg/day) - Mean (so) & $0.179(0.179)$ & $0.186(0.179)$ & $0.185(0.172)$ & $0.188(0.168)$ & $0.186(0.168)$ & $0.19 .(0.169)$ \\
\hline Lycopene (mg/dary) - Mean (sd) & $1.20(1.77)$ & $1.18(1.88)$ & $1.26(2.15)$ & $125(2.21)$ & $1.13(1.28)$ & $1.45(3.17)$ \\
\hline \multicolumn{7}{|l|}{ Dietary viltamins } \\
\hline Vitamin A (rethnol) (mg/day) - Mean (sd) & $0.970(0.418)$ & $0.97 \pi(0.429)$ & $0.967(0.428)$ & $0.977(0.453)$ & $0.981(0.455)$ & $0.971(0,454)$ \\
\hline Vittanin C (mg/day) - Mean (sd) & $103(43.8)$ & $103(44.8)$ & $102(43.8)$ & $102(43: 6)$ & $101(41.9)$ & $103(46.6)$ \\
\hline Vittamin E (mg/day) - Moran (sd) & $13.4(6.19)$ & $13.9(6.81)$ & $13.6(6: 14)$ & $13.6(6.29)$ & $13.4(6.44)$ & $13.8(6.09)$ \\
\hline Foldte (ngg/day) - Mean (sd) & $0.211(0.0722)$ & $0.2140(0.0771)$ & $0.21(0.0755)$ & $0.211(0.0780)$ & $0.208(0.0712)$ & $0.215(0.08891)$ \\
\hline \multicolumn{7}{|l|}{ Vitamin supplements } \\
\hline Supplemental vitamin $C$ user $-N(\%)$ & $289(6,9)$ & $19(6.1)$ & $15(6.7)$ & $12(6.7)$ & $5(4.6)$ & $7(10.1)$ \\
\hline Supplemental vitamin E user - N (\%) & $87(2.00)$ & $9(2.9)$ & $5(2.2)$ & $4(2.2)$ & $3(2.7)$ & $1(1.5)$ \\
\hline Supplemental vitumin $A D$ user - N $(\%)$ & $130(2.9)$ & Ifi (3.5) & $6(2.7)$ & $5(2.8)$ & $3(2.7)$ & $2(2,9)$ \\
\hline Supplemental nuultivitamin use - $\mathbb{N}(\%)$ & $207(4.7)$ & $21(6.7)$ & $16(7.1)$ & 11. (6.2) & $4(3.6)$ & $7(10.1)$ \\
\hline \multicolumn{7}{|l|}{ Confounding factors } \\
\hline Age - Mean (sd) & $61.4(4.23)$ & $61.9(9.88)$ & $62.0(3.87)$ & $61.7(3.82)$ & $61.8(3.76)$ & $50.5(3.92)$ \\
\hline Sex $=$ Male $-N(\%)$ & $21.91(49.4)$ & $207(659)$ & $143(631,6)$ & $108 \cdot(60.3)$ & $69(627)$ & $39(56.5)$ \\
\hline \multicolumn{7}{|l|}{ Cigarette snoker } \\
\hline Never - N $(\%)$ & $1590(35,8)$ & $78(24,8)$ & $58(25.8)$ & $47(263)$ & $31(28.2)$ & $16(23.2)$ \\
\hline $\mathrm{Ex}-\mathrm{N}(\%)$ & $1593(35.9)$ & $122(38.9)$ & $91(40.4)$ & $74(41.3)$ & $47(42.7)$ & $27(39.1)$ \\
\hline Current - N $(\%)$ & $1255(28.3)$ & $114(36,3)$ & $76(33.8)$ & $58(32.4)$ & $32(29.1)$ & $26(37.7)$ \\
\hline Number in analysiest & $\mathbb{N}=4272$ & $N=293$ & $N=209$ & $N=168$ & $N=102$ & $N=66$ \\
\hline Cigarettes smoked per day - Mean (sd) & $9.51(10.9)$ & $13.4(13.1)$ & $13.3(13.4)$ & $13.7(13.9)$ & $13.6(13.4)$ & $13.8(14,8)$ \\
\hline Number in analyses ${ }^{\text {a }}$ & $N=4380$ & $\mathbb{N}=3: 10$ & $N=223$ & Noin 177 & $\mathrm{~N}=109$ & $\mathrm{~N}=68$ \\
\hline Years of eigarette smoking - Mean (sd) & $20.2(18.2)$ & $25.5(1.8 .2)$ & $24.8(18.1)$ & $24.2(18.0)$ & $23.6(18.0)$ & $25.2(17.9)$ \\
\hline Kidney cancer in first-dege rellatives - $\mathrm{N}(\%)$ & $43(1.00)$ & $301.00)$ & $3(1 \times 3)$ & $2(1: 1)$ & $2(1.8)$ & 0 \\
\hline Number in analyses" & $N=4292$ & $N=304$ & $N=215$ & $N=172$ & $N=104$ & $N=68$ \\
\hline BMI $\left(\mathrm{kg} / \mathrm{m}^{2}\right)-$ Mem $(\mathrm{sd})$ & $25.0(3+12)$ & $28.5(2: 95)$ & $25.3(2.89)$ & $25.8(3.009)$ & $25.8(305)$ & $25.8(2.93)$ \\
\hline History of hypertension - N $(0,0)$ & $1156(26.1)$ & $94(29.9)$ & $66(29,3)$ & $52(29.1)$ & $35(3 \perp .8)$ & $17(24.6)$ \\
\hline
\end{tabular}

"The number of cases was lower in analyses for number of cigareites smoked per day, number of years of cigarette smoking. and $\mathrm{a}$ Mll due to nisising values. 
Table 7.2 Relative risks for the association of dietary carotenoid and vitamin intake, and supplemental vitamin use and Renal Cell Carcinoma (RCC), clear-cell RCC and clear-cell RCC with or without a von Hippel-Lindau gene mutation, Netherlands cohort study on diet and cancer 19861997.

\begin{tabular}{|c|c|c|c|c|c|}
\hline Camotenojd/Vitamin & $\begin{array}{l}\text { Median intake } \\
\text { in subcohort }\end{array}$ & $\mathrm{RCC}$ & Clear-cell RCC & $\begin{array}{l}\text { Clear-oll RCC } \\
\text { whL gene mutated }\end{array}$ & $\begin{array}{l}\text { Clear-cell RaCC } \\
\text { wildype }\end{array}$ \\
\hline$:$ & Men / Women & RR $(95 \% \mathrm{CD})$ & RR $(95 \% \mathrm{CD})$ & $\operatorname{RR}(95 \% \mathrm{CI})$ & $\operatorname{RR}(95 \% \mathrm{Cl})$ \\
\hline Number of cases & & 284 & 162 & 97 & $65^{\prime \prime}$ \\
\hline $\begin{array}{l}\text { Wumber person-years in } \\
\text { subcothort }\end{array}$ & & 42,972 & 42972 & 42,972 & 42,972 \\
\hline \multicolumn{6}{|l|}{ Apha-caroterbe } \\
\hline Q\| & $0.19 / 0.18$ & 1 (reference) & 1 (neference) & 1 (refterence) & 1. (reference) \\
\hline$Q 2$ & $0.38: 0.37$ & $0.85(0.59-1.24)$ & $0.81(0.49 \times 1.344)$ & $0.67(0.35-1.28)$ & $1.07(0.48-2.38)$ \\
\hline Q3 & $0.57 / 0.56$ & $0.82(0.56-1.20)$ & $0.97(0.60-1.57)$ & $0.93(0.51-1.68)$ & $1.04(0.47-2.32)$ \\
\hline Q4 & $0.82 / 0.82$ & $0.76(0.52-1.12)$ & $0.76(0.45-1.26)$ & $0.61(0.31-1.17)$ & $1.05(0.472 .34)$ \\
\hline Q5 & $1.31 / 1.32$ & $0.90(0.62-1.31)$ & $0.96(0.59+1.57)$ & $0.84(0.45-1.55)$ & $1.20(0.542 .65)$ \\
\hline trend & & 0.46 & 0.80 & 0.53 & 0.71 \\
\hline Continuous per $0.1 \mathrm{mg} / \mathrm{day}$ & & $0.99(0.97-1.01)$ & $0.98(0.96-1.01)$ & $0.98(0.95-1.02)$ & $0.99(0.95-1.03)$ \\
\hline \multicolumn{6}{|l|}{ Beta-carotene } \\
\hline Q1 & $1.48 / 1.39$ & 1 (reference) & 1 (refierence) & 1 (reference) & I(reference) \\
\hline $\mathrm{Q} 2$ & $2.14 / 2.03$ & $0.76(0.51-1.12)$ & $0.92(0.54-1.55)$ & $0.89(0.45-1.74)$ & $0.96(0.43-2.17)$ \\
\hline$Q 3$ & $2.67 / 2.61$ & $0.84(0.57-1.23)$ & $1.22(0.74-2.01)$ & $1.26(0.67-2.36)$ & $1.17(0.53-2.56)$ \\
\hline Q4 & $3.37 / 3.32$ & $0.84(0.57-1.23)$ & $1.01(0.61-1.69)$ & $1.09(0.58-2,07)$ & $0.89(0.39-2.04)$ \\
\hline Q5 & $4.75 / 4.72$ & $0.97(0.67-1.40)$ & $1.09(0.66-1.82)$ & $.0 .94(0.48-1.83)$ & $1.34(0.62-289)$ \\
\hline petrend & & 0.95 & 0.64 & 0.92 & 0.54 \\
\hline Continulous per $1 \mathrm{ng} / \mathrm{day}$ & & $0.98(0.91-1.06)$ & $0.96(0.87-1.05)$ & $0.95(0.84-1.07)$ & $0.98(0.85-1.12)$ \\
\hline \multicolumn{6}{|l|}{ Lutein -Zeaxanthin } \\
\hline$Q_{1}$ & $1.42 / 1.30$ & 1 (reference) & 1 (reference) & 1 (reference) & 1 (reforence) \\
\hline $\mathrm{Q} 2^{2}$ & $1.89 / 1.81$ & $0.66(0.45-0.99)$ & $0.68(0.4 k-1.13)$ & $0.57(0.28-1.14)$ & $0.84(0.40-1.79)$ \\
\hline Q3 & $2.37 / 2.29$ & $0.79(0.54-1.16)$ & $0.81(0.49-1.31)$ & $0.78(0.41-1.46)$ & $0.85(0.40-1.79)$ \\
\hline Q4 & $2.86 / 2.78$ & $0.92(0.64-1.33)$ & $0.99(0.62-1.58)$ & $1.12(0.63-2.02)$ & $0.79(0.37-1.68)$ \\
\hline Q5 & $3.89 / 3.77$ & $0.90(0.62-1.29)$ & $0.76(0.46-1.25)$ & $0.76(0.40-1.45)$ & $0.76(0.35-1.63)$ \\
\hline$p$ trend & & 0.88 & 0.74 & 0.89 & 0.48 \\
\hline Conthinuous pet 1 mg/day & & $1.01(0.91-1,12)$ & $0.96(0.84+1.10)$ & $0.98(0.81-1.17)$ & $0.94(0.76-1.15)$ \\
\hline \multicolumn{6}{|l|}{$\begin{array}{l}\text { Continuous per l mgroay } \\
\text { Betawcryptoxanthin }\end{array}$} \\
\hline Q & $0.01 / 0.03$ & 1 (reference) & 1 (reference) & I (feference) & 1 (reference) \\
\hline$Q 2$ & $0.04 / 0.09$ & $1.08(0.72-1.62)$ & $1.24(0.72-2+13)$ & $1.00(0.52-1.93)$ & $1.88(0.73-4.82)$ \\
\hline$Q 3$ & $0.10 / 0.17$ & $0.99(0.65-1.50)$ & $1.11(0.64-1.93)$ & $0.63(0.30-1.32)$ & $2.40(0.97-5.95)$ \\
\hline Q4 & $0.20 / 0.27$ & $1.56(1.06-2.28)$ & $1.58(0.95-2.65)$ & $1.18(0.63-2.22)$ & $2.64(1.08-6.46)$ \\
\hline Q5 & $0.36 / 0.50$ & $1.17(0.78-1.74)$ & $1.40(0.83-2.36)$ & $1.30(0.70-2.42)$ & $1.61(0.62-4.16)$ \\
\hline$p$ trend & & 0.11 & 0.11 & 0.31 & 0.118 \\
\hline Continuous per $0.05 \mathrm{mg} / \mathrm{day}$ & & $1.03(1.00-1.06)$ & $1.03(0.99-1.07)$ & $1.03(0.98-1.088)$ & $1.03(0.97-1.09)$ \\
\hline \multicolumn{6}{|l|}{$\begin{array}{l}\text { Continuous per } 0.05 \mathrm{mg} / \mathrm{day} \\
\text { Lycopene }\end{array}$} \\
\hline $\mathrm{Q} 1$ & $0.14 / 0.17$ & 1 (reference) & $\mathbb{1}($ reference) & 1 (feference) & 1 (reference) \\
\hline Q2 & $0.42 / 0.56$ & $0.90(0.59-1.35)$ & $0.68(0.38-11.21)$ & $0.81(0.41-1.63)$ & $0.45(0.16-1.29)$ \\
\hline$Q 3$ & $0.74 / 0.90$ & $1.12(0.76-1.67)$ & $121(0.73-2.00)$ & 1. $10(0.58-2.091)$ & $1.40(0.64-3.06)$ \\
\hline Q4 & $1.11 / 1.30$ & $1.35(0.93-1.98)$ & $1.47(0.90-2.38)$ & $1.26(0.68-2.36)$ & $1.81(0.86-3.82)$ \\
\hline$Q 5$ & $1.98 / 2.33$ & $1.17(0.79 \times 1.72)$ & $1.23(0.74-2.04)$ & $1.13(0.59-2.16)$ & $1.39(0.64-3.05)$ \\
\hline$p$ trend & & 0.10 & 0.05 & 0.36 & 0.04 \\
\hline Continuous per $0.5 \mathrm{mg} / \mathrm{day}$ & & $1.01(0.88-1.17)$ & $1,05(0,88-25 y$ & $0.96(0.79-1.18)$ & $1.13(0.89-1.44)$ \\
\hline
\end{tabular}




\begin{tabular}{|c|c|c|c|c|c|}
\hline \multirow[t]{2}{*}{ Carotenoud/Vitamili } & \multirow{2}{*}{$\begin{array}{l}\text { Median Holke } \\
\text { in subicolinort } \\
\text { Men / Women }\end{array}$} & \multirow{2}{*}{$\begin{array}{l}\mathrm{RCC} \\
\mathrm{RR}(05 \% \mathrm{CT})\end{array}$} & Clear-cell RCC & \multirow{2}{*}{$\begin{array}{l}\text { Cletritetll RCC } \\
\text { WHL gent mutarted } \\
\text { RR }(95 \% \mathrm{CD})\end{array}$} & $\begin{array}{l}\text { Clear-cell RCC } \\
\text { wildtype }\end{array}$ \\
\hline & & & RR $(95 \% \mathrm{Cl})$ & & $\operatorname{RR}(95 \% \mathrm{CD})$ \\
\hline Number of cases & & 284 & 162 & 97 & 65 \\
\hline $\begin{array}{l}\text { Nunbor person-years in } \\
\text { subcolwont }\end{array}$ & & 42,972 & 42,972 & 42,972 & 42,972 \\
\hline \multicolumn{6}{|l|}{ Vitamin (retinol) } \\
\hline 01 & $0.61+0.52$ & 1 (reference) & 1 (referencice) & 1 (refference) & 1. (refierence) \\
\hline$Q 2$ & $0.81 / 0.70$ & $1.01(0.69-1.48)$ & $0.96(0.58-1.60)$ & $1.11(0.59-2.10)$ & $0.76(0.34-1.72)$ \\
\hline Q3 & $0.95 / 0.84$ & $1.00(0.68-1.47)$ & $1.12(0.69-1.84)$ & $1.14(0.60+2.14)$ & $1.11(0.52-2.36)$ \\
\hline Q⿻肀二丿 & $1.14 / 1.01$ & $0.73(0.48-1.11)$ & $0.75(0.44-1.29)$ & $0.89(0.45-1.75)$ & $0.57(0.23-1.37)$ \\
\hline QS & $1.51 / 1.37$ & $1.13(0.78-1.64)$ & $1.05(0.64-1.72)$ & $0.94(0.49-1.81)$ & $1.20(0.58-2.48)$ \\
\hline$p$ trend & & 0.96 & 0.84 & 0.63 & 0.81 \\
\hline Continuous per $0.1 \mathrm{mg} /$ day & & $0.99(0.96-1.03)$ & $1.00(0.95-1.04)$ & $1.00(0.94-1.05)$ & $1.00(0.94-1.06)$ \\
\hline \multicolumn{6}{|l|}{ Vitaminc } \\
\hline$Q 1$ & $5223 / 58.93$ & 1 (reference) & 1. (reference) & 1 (reference) & 1. (reference) \\
\hline$Q 2+Q 3$ & $81.78 / 92.73$ & $1.10(0.78-1.55)$ & $1.04(0.67-1.60)$ & $0.90(0.52-1.56)$ & $1.28(0.65-2.55)$ \\
\hline$Q^{4}+Q S$ & $129.76 / 140.84$ & $+1.01(0.72-1.43)$ & $0.88(0.57-1.38)$ & $0.87(0.50-1.50)$ & $0.91(0.44-1.87)$ \\
\hline$p$ trend & & 0.99 & 0.48 & 0,63 & 0.58 \\
\hline Contin unous per $10 \mathrm{~min} / \mathrm{day}$ & & $1.01(0.98-1.04)$ & $0.99(0.96-1.03)$ & $0.99(0.94-1.04)$ & $1.00(0.94-1.06)$ \\
\hline \multicolumn{6}{|l|}{ Vitamin $\mathbb{E}$} \\
\hline Q1 & $7.18 / 6.13$ & 1 (referemce) & 1 (reference) & 1 (reference) & 1 (reference) \\
\hline $\mathrm{Q2}$ & $10.56 / 8.54$ & $0.77(0.53 \times 1.16)$ & $0.66(0.38-1.15)$ & $0.91(0.46-1.78)$ & $0.35(0.12-0.97)$ \\
\hline Q3 & $13.54 / 11.05$ & $1.09(0.75-1.58)$ & $1.16(0.72-1.88)$ & $1.53(0.84-2.80)$ & $0.69(0.30-1.57)$ \\
\hline Q4 & $17.20 / 14.40$ & $1.04(0.72-1.52)$ & $1.13(0.70-1.81)$ & $0.74(0.37-1.49)$ & $1.63(0.85-3.13)$ \\
\hline 05 & $23.76 / 19.55$ & $1.00(0.68-1.47)$ & $0.90(0.54-1.50)$ & $1.00(0.52 * 1.93)$ & $0.76(0.34-1.70)$ \\
\hline$p$ trend & & 0.53 & 0.63 & 0.81 & 0.30 \\
\hline Continuous per 5 mag/day & & $1.05(0.95-1.15)$ & $1.03(0.90-1.16)$ & $1.00(0.84-1,19)$ & $1.07(0.89 \% 1.27)$ \\
\hline \multicolumn{6}{|l|}{ Folate } \\
\hline $\mathrm{Q}$ & $0.15 / 0.13$ & (reference) & I (reference) & 1 (reference) & 1 (reference) \\
\hline$Q 2$ & $0.18 / 0.16$ & $0.83(0.56-1.24)$ & $0.74(0.44-1.24)$ & $0.62(0.33-1.19)$ & $0.99(0.42-2.34)$ \\
\hline$Q^{3}$ & $0.21 / 0.19$ & $1.04(0.72-1.52)$ & $1.08(0.74-1.77)$ & $1.02(0.58-1.80)$ & $1.20(0.54 .2 .66)$ \\
\hline Q4 & $025 / 0.22$ & $0.86(0.58-1.27)$ & $0.510(0.49-1.35)$ & $0.52(0.26-1.05)$ & $1.44(0.66-3.14)$ \\
\hline 05 & $0.31 / 0.27$ & $0.95(0.65 \cdot 1.40)$ & $0.79(0.48 \times 1.31)$ & $0.65(0.34 \times 1.23)$ & $1.10(0.49-2.48)$ \\
\hline$p$ trend & & 0.88 & 0.50 & 0.17 & 0.52 \\
\hline Contirulum per $0.1 \mathrm{~m} n / \mathrm{dag}$ & & $0.99(0.83-1.199)$ & $0.95(0.73-1.23)$ & $0.88(0.62-1.23)$ & $1.05(0.71-1.53)$ \\
\hline \multicolumn{6}{|l|}{ Supplenrent use } \\
\hline No & & I (referente) & 1 (nelprence) & 1 (reference) & 1 (reference) \\
\hline Supplemental witamain $\mathrm{C}$ user & & $0.95(0.57-1.58)$ & $1.07(0.57-2.02)$ & $0.64(0.23-1.75)$ & $1.76(0.79-3.95)$ \\
\hline Supplemental witanin E Hser & & $1.83(0.89-3.78)$ & $1.42(0.50 \times 4.01)$ & $1.92(0.59-6.31)$ & $0.81(0.11-6.07)$ \\
\hline Supplemental vitramin $\mathrm{AD}$ i.sser & & $1.42(0.74-2.73)$ & $1.04(0.41-2.67)$ & $1.12(0.33-3.74)$ & $0.95(0.22-5.75)$ \\
\hline Supplenental axtultivittamin use & & $1.51(0.91-2.51)$ & $1.43(0.73-2.79)$ & $0.72(0.22-2.28)$ & $2.5 .1(1.10-5.75)$ \\
\hline
\end{tabular}

All models adjusted for age, sex, smoking (current smoker yes or no; number of cigarettes per day; number of smoking years), BMI and history of hypertension. Supplemental witanin C, E, AD and multivitamin use are simultaneously entered in one model. 
We also investigated possible interaction by sex and cigarette smoking status. Although we observed a statistically significant interaction of sex and beta-carotene intake for $\mathrm{RCC}(p=0.03)$, stratified analyses showed that there was no consistent differential effect for sex over the quintiles (results not shown). Table 7.3 shows results stratified by smoking and $p$ values for interaction with smoking. There were no statistically significant differential results for the intake of carotenoids, vitamins or the use of supplements. We repeated these analyses for the subgroups of clear-cell cases with or without a $V H L$ gene mutation. No conclusions could be drawn based on these results since the low number of cases, especially in the supplemental vitamin use groups, hampered analyses (data not shown).

Table 7.3 Relative risks for the association of carotenoid and vitamin intake and renal cell carcinoma (RCC), stratified by smoking status. Netherlands cohort study on diet and cancer 1986-1997.

\begin{tabular}{|c|c|c|c|c|}
\hline Carotenoid/Vitamin & $\begin{array}{l}\text { Never smokers } \\
\text { RR }(95 \% \mathrm{CI})\end{array}$ & $\begin{array}{l}\text { Ex-smokers } \\
\mathrm{RR}(95 \% \mathrm{Cl}) \\
\end{array}$ & $\begin{array}{l}\text { Current smokers } \\
\operatorname{RR}(95 \% \text { Cil }\end{array}$ & $\begin{array}{l}p \text { value for } \\
\text { interaction }\end{array}$ \\
\hline Number of cases & 75 & 111 & 98 & \\
\hline Number person-years in subcohort & 16,543 & 15,182 & 11,247 & \\
\hline \multicolumn{5}{|l|}{ Alpha-carotene } \\
\hline Q1 & 1 (reference) & 1 (reference) & 1 (reference) & 0.29 \\
\hline $\mathrm{Q} 2$ & $0.54(0.25-1.13)$ & $1.16(0.65-2.09)$ & $0.80(0.41-1.58)$ & \\
\hline Q3 & $0.80(0.41-1.56)$ & $0.74(0.39-1.41)$ & $0.93(0.48-1.80)$ & \\
\hline Q4 & $0.63(0.30-1.29)$ & $0.66(0.35-1.26)$ & $1.05(0.55-2.01)$ & \\
\hline Q5 & $0.46(0.22-0.96)$ & $1.06(0.58-1.95)$ & $1.22(0.65-2.30)$ & \\
\hline$p$ trend & 0.09 & 0.53 & 0.39 & \\
\hline Contimuous per $0.1 \mathrm{mg} /$ day & $0.95(0.91-0.99)$ & $1.00(0.96-1.03)$ & $1.01(0.98-1.05)$ & \\
\hline \multicolumn{5}{|l|}{ Beta-carotene } \\
\hline Q1 & I (reference) & 1 (reference) & 1 (reference) & 0.18 \\
\hline $\mathrm{Q} 2$ & $0.80(0.39-1.66)$ & $0.54(0.28-1.02)$ & $1.02(0.52-2.01)$ & \\
\hline $\mathrm{Q3}$ & $0.84(0.40-1.74)$ & $0.80(0.45-1.45)$ & $0.88(0.43-1.79)$ & \\
\hline Q4 & $0.99(0.49+1.99)$ & $0.48(0.26-0.92)$ & $1.30(0.67-2.51)$ & \\
\hline Q5 & $0.53(0.24-1.17)$ & $0.96(0.54-1.68)$ & $1.47(0.77-2.78)$ & \\
\hline$p$ trend & 0.25 & 0.80 & 0.18 & \\
\hline Continuous per $1 \mathrm{mg} / \mathrm{day}$ & $0.86(0.74-1.00)$ & $1.00(0.87-1.13)$ & $1.06(0.94-1.19)$ & \\
\hline \multicolumn{5}{|l|}{ Lutein + Zeaxanthin } \\
\hline $\mathrm{Q} 1$ & 1 (reference) & 1 (reference) & 1 (reference) & 0.57 \\
\hline $\mathrm{Q}^{2}$ & $0.53(0.24-1.18)$ & $0.76(0.39-1.46)$ & $0.67(0.35-1.30)$ & \\
\hline $\mathrm{Q}^{3}$ & $0.83(0.41-1.67)$ & $1.02(0.55-1.87)$ & $0.53(0.26-1.08)$ & \\
\hline Q4 & $0.96(0.49-1.88)$ & $1.09(01.59-2.00)$ & $0.75(0.39-1.42)$ & \\
\hline Q5 & $0.58(0.27-1.22)$ & $0.92(0.49-1.75)$ & $1.13(0.64-1.99)$ & \\
\hline$p$ trend & 0.49 & 0.78 & 0.61 & \\
\hline Continuous per $1 \mathrm{mg} /$ day & $0.91(0.73-1.15)$ & $1.04(0.87-1.24)$ & $1.04(0.90-1.20)$ & \\
\hline
\end{tabular}




\begin{tabular}{|c|c|c|c|c|}
\hline Carotenoid/Vitamin & $\begin{array}{l}\text { Never smokers } \\
\text { R } 195 \% \mathrm{Cl}\end{array}$ & $\begin{array}{l}\text { Ex-smokers } \\
\text { RR }(95 \% \mathrm{Cl})\end{array}$ & $\begin{array}{l}\text { Current smokers } \\
\text { RR }(95 \% \text { CI) }\end{array}$ & $\begin{array}{l}p \text { vallue for } \\
\text { interaction }\end{array}$ \\
\hline Number of cases & 75 & 111 & $98: \div$ & \\
\hline Number person-yeats in subcohort & 16,543 & 15,182 & 11,247 & \\
\hline \multicolumn{5}{|c|}{ Betamcryptoxandin } \\
\hline Q1 & 1 (reference) & 1 (teference) & 1 (reference) & 0.24 \\
\hline 02 & $0.59(0.26-1.36)$ & $1.06(0.54-2.07)$ & $1.56(0.81-3.02)$ & \\
\hline$\therefore$ & $0.91(0.43 \cdots 1.93)$ & $0.79(0.39-1.60)$ & $1.27(0.63-2.57)$ & \\
\hline 04 & $1.26(0.63-2.52)$ & $1.21(0.64-2.29)$ & $2.30(1.23-431)$ & \\
\hline Q5 & $0.82(0.38-1.76)$ & $1.52(0.82-2.81)$ & $0.97(0.46-2.07)$ & \\
\hline$p$ trend & 0.65 & 0.14 & 0.42 & \\
\hline Cothunous per $0.05 \mathrm{mg} / \mathrm{day}$ & $1.01(0.95-1.07)$ & $1.06(1.01-1.11)$ & $1.02(0.96-1.08)$ & \\
\hline \multicolumn{5}{|l|}{ Lycoperie } \\
\hline Q1 & 1 (reference) & 1 (reference) & 1 (reference) & 0.81 \\
\hline Q2 & $0.81(0.37-1.77)$ & $1.10(0.54-2.24)$ & $0.82(0.41-1.65)$ & \\
\hline Q3 & $1.21(0.59-2.47)$ & $1.28(0.65-2.54)$ & $0.92(0.47-1.83)$ & \\
\hline Q4 & $0.86(0.40-1.86)$ & $1.83(0.96-3.49)$ & $1.42(0.76-2.63)$ & \\
\hline QS & $1.25(0.61-2.54)$ & $1.44(0.73-2.84)$ & $0.92(0.47-1.81)$ & \\
\hline$p$ trend & 0.54 & 0.09 & 0.60 & \\
\hline Continuous per $0.5 \mathrm{mg} / \mathrm{day}$ & $0.98(0.80-1.22)$ & $1.06(0.85-1.32)$ & $0.97(0.73-1.29)$ & \\
\hline \multicolumn{5}{|l|}{ Vitamin A (retinol) } \\
\hline QI & 1 (reference) & 1 (reference) & 1 (reference) & 0.38 \\
\hline$Q_{2}$ & $0.85(0.39-1.83)$ & $1.54(0.86-2.77)$ & $0.67(0.34-1.34)$ & \\
\hline$Q 3$ & $1.31(0.66-2.60)$ & $1.02(0.54-1.94)$ & $0.76(0.38-1.50)$ & \\
\hline Q4 & $0.81(0.37-1.75)$ & $0.80(0.40-1.60)$ & $0.62(0.31-1.24)$ & \\
\hline Q5 & $0.84(0.39-1.81)$ & $1.28(0.69-2.38)$ & $1.19(0.64-2.20)$ & \\
\hline$p$ trend & 0.65 & 0.83 & 0.55 & \\
\hline Continuous per $0.1 \mathrm{mg} / \mathrm{day}$ & $0.97(0.90-1.04)$ & $1.01(0.95-1.07)$ & $1.00(0.96 m 1.04)$ & \\
\hline \multicolumn{5}{|l|}{ Vitamin $C$} \\
\hline QI & 1 (reference) & 1 (reference) & 1 (reference) & 0.29 \\
\hline $\mathrm{Q}_{2}+\mathrm{Q}_{3}$ & $0.97(0.50-1.87)$ & $0.81(0.47-1.42)$ & $1.62(0.91-2.89)$ & \\
\hline$Q_{4}+Q_{5}$ & $0.99(0.52-1.89)$ & $0.98(0.57-1.68)$ & $1.04(0.57-1.90)$ & \\
\hline$p$ trand & 0.99 & 0.85 & 0.78 & \\
\hline Continuous per $10 \mathrm{mg} / \mathrm{day}$ & $0.98(0.93-1.03)$ & $1.03(0.98-1.08)$ & $1.01(0.97-1.05)$ & \\
\hline \multicolumn{5}{|l|}{ Vitamin $\mathrm{E}$} \\
\hline $\mathrm{QH}$ & I (reference) & 1 (reference) & 1 (reference) & 0.25 \\
\hline Q2 & $0.67(0.32-1.40)$ & $0.69(0.35-1.36)$ & $0.98(0.48-2.01)$ & \\
\hline$Q 3$ & $0.97(0.49-1.91)$ & $1.13(0.61-2.10)$ & $1.15(0.59-2.21)$ & \\
\hline Q4 & $0.75(0.37-1.51)$ & $1.32(0.73-2.39)$ & $1.00(0.50-1.98)$ & \\
\hline Q5 & $0.49(0.22-1.07)$ & $0.94(0.50-1.75)$ & $1.72(0.91-3.28)$ & \\
\hline$p$ trend & 0.13 & 0.45 & 0.14 & \\
\hline Continuous per $5 \mathrm{mg} / \mathrm{day}$ & $0.88(0.69-1.12)$ & $1.01(0.88 \mathrm{~m} 1.15)$ & $1.19(1.02-1.40)$ & \\
\hline
\end{tabular}




\begin{tabular}{|c|c|c|c|c|}
\hline $\begin{array}{l}\text { Carotenoid/Nitamin } \\
\end{array}$ & $\begin{array}{l}\text { Newer smokers } \\
\text { RR }(95 \% \text { CI) }\end{array}$ & $\begin{array}{l}\text { Ex-smokers } \\
\text { RR }(95 \% \mathrm{Cl})\end{array}$ & $\begin{array}{l}\text { Current snokers } \\
\mathrm{RR}(95 \% \mathrm{Cl})\end{array}$ & $\begin{array}{l}p \text { value for } \\
\text { interaction }\end{array}$ \\
\hline Number of cases & 75 & 111 & 98 & \\
\hline Number person-years in subcohort & 16,543 & 15,182 & 11,247 & \\
\hline \multicolumn{5}{|l|}{ Folate } \\
\hline Q1 & 1 (reference) & 1 (reference) & 1 (reference) & 0.17 \\
\hline $\mathrm{Q} 2$ & $0.92(0.43-1.94)$ & $0.66(0.33-1.33)$ & $0.97(0.51-1.86)$ & \\
\hline Q3 & $1.56(0.80-3.03)$ & $1.05(0.57-1.94)$ & $0.71(0.37-1.37)$ & \\
\hline Q4 & $0.66(0.29-1.51)$ & $1.25(0.68-2.29)$ & $0.62(0.31-1.24)$ & \\
\hline Q5 & $0.79(0.36-1.74)$ & $1.05(0.55-1.98)$ & $0.96(0.52-1.80)$ & \\
\hline$p$ trend & 0.40 & 0.32 & 0.59 & \\
\hline Continuous per $0.1 \mathrm{mg} / \mathrm{day}$ & $0.85(0.58-1.23)$ & $1.24(0.91-1.69)$ & $0.87(0.65-1.15)$ & \\
\hline \multicolumn{5}{|l|}{ Supplement use } \\
\hline No & 1 (reference) & 1 (reference) & 1 (reference) & \\
\hline Supplemental vitamin $\mathrm{C}$ user & $0.61(0.17-2.1 .5)$ & $1.05(0.49-2.27)$ & $1.09(0.46-2.56)$ & 0.69 \\
\hline Supplemental vitamin $\mathbf{E}$ user & $1.76(0.38-8.08)$ & $2.22(0.83-5.95)$ & $1.13(0.22-5.86)$ & 0.85 \\
\hline Supplemental vitamin AD user & $1.23(0.36-4.19)$ & $0.89(0.26-3.07)$ & $2.63(0.87-7.94)$ & 0.40 \\
\hline Supplemental multivitamin use & $1.16(0.40-3.34)$ & $2.02(0.97-4.21)$ & $1.41(0.52-3.87)$ & 0.71 \\
\hline
\end{tabular}

Models adjusted for age, sex, BMI, history of hypertension, and for ex and current smokers additionally adjusted for: number of cigarettes per day; number of smoking years. Supplemental vitamin $C, E, A D$ and multivitamin use are simultaneously entered in one model.

\section{Discussion}

We investigated the association of several dietary carotenoids and vitamins $(\mathrm{A}, \mathrm{C}, \mathrm{E}$ and folate) and supplemental vitamin $\mathrm{C}, \mathrm{E}, \mathrm{AD}$ and multivitamin use and $\mathrm{RCC}$ incidence in the Netherlands Cohort Study on diet and cancer (NLCS). We observed no association for carotenoids and vitamins from diet and RCC risk. This is not surprising, since we also observed null associations for vegetable and fruit consumption and RCC risk ${ }^{37}$. Contrary to expectations, we observed a small statistically non-significant increased risk with supplemental vitamin $\mathrm{E}, \mathrm{AD}$, and multivitamin use.

Important strengths from the NLCS are that exposure was assessed before the diagnosis of cancer and that only incident cases were included. Therefore, recall bias is not likely to have influenced our results. Furthermore, selection bias is also unlikely because of the high completeness of follow-up of cases and subcohort members.

The consumption of vegetables and fruits, which contribute the most to the intake of carotenoids and vitamins, was extensively measured in the NLCS, using a validated semi-quantitative food-frequency questionnaire. Misclassification of exposure might have occurred. However, from our validation study it was concluded that the questionnaire could satisfactorily rank subjects according to the intake of nutrients and food groups ${ }^{26}$. In a reproducibility study, it was further demonstrated that the single food frequency questionnaire measurement could characterize dietary habits for a period of at least 5 years $^{38}$. If misclassification has accurred, we expect this to be 
nondifferential and risk estimates are most likely biased towards the null value. This may explain our negative results. However, for vegetable and fruit consumption, a very important source of carotenoids and vitamins, we believed this to be an unlikely explanation for the observed null association with $\mathrm{RCC}^{37}$, since statistically significant associations had been observed for vegetable and fruit consumption and lung ${ }^{39}$ and colorectal $^{\text {tid }}$ cancer within the NLCS previously. However, this was less clear for previous studies on carotenoids and vitamins within the $\mathrm{NLCS}^{41-44}$. The assessment of intake of vitamin supplements was also shown to be reasonably good in our study ${ }^{32}$.

The number of cases in this prospective cohort study, the second to report on carotenoids, vitamins and supplement intake, was reasonably large. The lowa Women's Health Study ${ }^{13}$ was the first cohort study to report on carotenoids, vitamins and supplement use, analyzing 124 incident cases after 15 years of follow-up. In the current study, we observed 314 incident RCC cases after 11.3 years of follow-up.

We cannot exclude the possibility that residual confounding has influenced our results, even though we tried to investigate and adjust for the appropriate confounding factors. All possible confounding factors as reported from the literature and measured within the cohort were included in the analyses if associated with RCC risk and correlated with at least one of the exposure factors in our population. Chance may have played a role since a large number of associations was tested, but we hardly observed statistically significant associations. Finally, power may have been a problem since the number of cases in subgroup analyses was sometimes low, although results across quintiles did not point in the direction of a dose-response relationship.

For carotenoids, there was an indication for a u-shaped association with RCC. This was less clear in the case groups of clear-cell RCC, and clear-cell RCC with or without a $V H L$ gene mutation, possibly because of the smaller number of cases. This observation is in line with the observation of a u-shaped association with higher mutation frequencies at lower and higher intakes of dietary carotenoid intake ${ }^{10}$. Despite these suggestive results, we only observed a statistically significant inverse association in quintile 2 of luteintzeaxanthin intake. For lycopene and beta-cryptoxanthin, risks seemed to be increased, without an indication of a u-shaped association. Lycopene is mainly derived from tomatoes, and citrus fruits including mandarins are an important source of beta-cryptoxanthin. Both tomato consumption and mandarin consumption were associated with a increased RCC risk in our population ${ }^{37}$. We could not explain the previously observed results for tomato and mandarin consumption and ascribed them to chance. Most results for carotenoids were not statistically significant, leading us to conclude that there was no association with RCC risk. These results are in line with most other studies, which reported statistically non-significant inverse and null associations ${ }^{13,16,20,21}$. The only study to report statistically significant inverse associations for alpha-carotene, beta-carotene, lutein, and beta-cryptoxanthin was a large population based case-control study including 1,204 cases ${ }^{15}$.

We observed no association of dietary vitamin intake and RCC risk. To our knowledge, folate has not been investigated in relation to RCC risk before. For vitamins $A$ and $\mathrm{E}$ 
null associations and non-statistically significant inverse associations have been reported $^{13,15,16,21}$. For vitamin $C$ intake, reported associations were also not statistically significant, but generally somewhat more suggestive of a possible protective effect $^{13,15,16,20}$.

Supplemental vitamin $E$ and multivitamin use seemed associated with an increased RCC risk (not statistically significant). One trial on vitamin supplementation and RCC risk was carried out (the ATBC study ${ }^{12}$ ). In this trial, male smokers were randomly assigned to supplemental alpha-tocopherol, beta-carotene, alpha-tocopherol and betacarotene, or a placebo. No statistically significant differences in incidence/mortality rates of RCC were observed ${ }^{12}$. However, an inverse association was observed with multivitamin supplement use in the lowa women's health study (RR: $0.63 ; 95 \% \mathrm{Cl}$ : $0.42-0.93)^{13}$. Two other large population-based case-control studies reported a null association with supplement use ${ }^{15,16}$.

We also investigated possible effect-modification by smoking. We did not observe a differential effect for never, ex and current smokers. Thus far, stronger inverse association for non-smokers ${ }^{16}$ as well as non-differential effects ${ }^{15}$ have been published. In the study by Hemminki et $a l^{8}{ }^{8}$ it was noted that smoking appeared to change the outcome of many variables (although smoking itself was not a risk factor for $V H L$ gene mutations). However, small numbers in that study did not allow for testing of smoking as a true effect modifier. In the current study, numbers were also too small to draw firm conclusions from interaction tests and from analyses, stratified by smoking.

We were able to investigate risk factors for the specific histological subtype clear-cell $\mathrm{RCC}$ and also for the presence of $V H L$ gene mutations, which has not been done before for vitamins and carotenoids. There has only been one report on diet and VHL gene mutations based on a case-only analysis ${ }^{8}$. The authors of that study concluded that their results provide evidence that the intake of vegetables, selenium and particularly citrus fruit protects the renal $V H L$ gene from mutational insults, although chance results could not be ruled out in that relatively small study ${ }^{8}$. Based on case-only comparisons, we would have observed a non-statistically significant protective effect of supplemental multivitamin intake on $V H L$ gene mutations (OR: 0.22; 95\% CI: 0.05-1.02). However, compared to the subcohort, the risk for wildtype $V H L$ tumors was increased (RR: 2.51 ; $95 \% \mathrm{Cl}: 1.10-5.75$ ) which shows that case-only comparisons can be misleading. Thus, we observed an increased risk for $V H L$ wildtype clear-cell tumors for supplement use and not a protective effect of supplemental multivitamin use on $V H L$ gene mutations. In summary, no statistically significant dose-response associations were observed. Stratified results by $V H L$ gene mutation showed no statistically significant differential effects, although results were sometimes suggestive of a differential effect. These associations should be investigated by others to confirm the current observations. 


\section{Acknowledgements}

We wish to thank Dr. E. Dorant, C. de Brouwwer, Prof. Dr. A. Geurts van Kessel and Prof. Dr. D. Ruiter for their preparatory work for this study; Dr. A. Volovics and Dr. A. Kester for statisticd advice; S. van de Crommert, H. Brants, J Nelissen, C. de Zwart, M. Moll, W. van Dijk, M. Jansen and A. Pisters for assistance, $H$, van Montfort, T. van Moergastel, L. van den Bosch and R. Schmeitz for programming assistance; and $K$. van Houwelingen and $H$. Gorissen for laboratory assistance. The authors also thank the staffs of the Dutch regional cancer registries and the Netherlands national database for pathology (PALGA) for providing incidence data. Finally, we would like to thank the participating pathological laboratories for providing paraffin material for a complete list, see: (33)). 


\section{References}

1. Ferlay J, Bray F, Sankila R, Parkin D. EUCAN: Cancer lncidence, Mortality and Prevalence in the European Union 1998, version 5.0. Lyon: LARC Press, 1999.

2. Coleman MP, Gatta $G_{3}$ Verdecchia A, et al. EUROCARE-3 summary: cancer survival in Europe at the end of the 20th century. Ann Oncol 2003;14 Suppl 5:v128-49.

3. Gnarra JR, Duan DR, Weng $Y$, et al. Molecular cloning of the von Hippel-Lindau tumor suppressor gene and its role in renal carcinoma. Biochim Biopliys Acta $1996 ; 1242: 201-10$.

4. Richards FM. Molecular pathology of von Hippel-Lindau disease and the VHL tumour suppressor gene. Expert Rev Mol Med 2001;2001:1-27.

5. Kaelin $W G$, Jr. The von hippel-lindau tumor suppressor gene and kidney cancer. Clin Cancer Res 2004:10:6290S-5S.

6. Brauch $\mathrm{H}$, Weirich $\mathrm{G}$, Hornauer MA, Storkel $\mathrm{S}$, Wohl T, Bruning T. Trichloroethylene exposure and specific somatic mutations in patients with renal cell carcinoma. I Natl Cancer Inst 1999;91:854-61.

7. Brauch $H$, Weirich $G$, Klein B, Rabstein S, Bolt HM, Bruning T, VHL mutations in renal cell cancer: does occupational exposure to trichloroethylene make a difference? Toxicol Lett 2004; 15 1:301-10.

8. Hemminki K, Jiang Y, Ma X, Yang K, Egevad L, Lindblad P. Molecular epidemiology of VHL gene mutations in renal cell carcinoma patients: relation to dietary and other factors. Carcinogenesis 2002;23:809-15.

9. Steinmetz KA, Potter JD. Vegetables, fruit, and cancer. II. Mechanisms. Cancer Causes Control $1991 ; 2: 427-42$.

10. Nyberg F, Hou SM, Pershagen G, Lambert B. Dietary fruit and vegetables protect against somatic mutation in vivo, but low or high intake of carotenoids does not. Carcinogenesis $2003 ; 24: 689-96$.

11. Seifried HE, McDonald SS, Anderson DE, Greenwald $\mathbb{P}$, Milner JA. The antioxidant conundrum in cancer. Cancer Res 2003;63:4295-8.

12. Virtamo J, Edwards BK, Virtanen M, et al. Effects of supplemental alpha-tocopherol and beta-carotene on urinary tract cancer: incidence and mortality in a controlled trial (Finland). Cancer Causes Control 2000;11:933-9.

13. Nicodemus KK, Sweeney C, Folsom AR. Evaluation of dietary, medical and lifestyle risk factors for incident kidney cancer in postmenopausal women. Int J Cancer $2004 ; 108: 115-21$.

14. Hu I, Mao $Y$, White K. Diet and vitamin or mineral supplements and risk of renal cell carcinoma in Canada Cancer Causes Control 2003;14:705-14.

15. Yuan. JM, Gago Dominguez $M$, Castelao JE, Hankin JH, Ross RK, Yu MC. Cruciferous vegetables in relation to renal cell carcinoma. Int J Cancer 1998;77:211-6\%.

1.6. Wolk A, Gridley G, Niwa $S$, et al. International renal-cell cancer study, VII. Role of diet. Int J Cancer 1996;65:67-73.

17. Chow WH, Gridley $\mathrm{G}$, McLaughlin $\mathrm{JK}_{\mathrm{K}}$, et al. Protein intake and risk of renal cell cancer. I Natl Cancer Inst 1994;86:1131-9.

18. Mellemgaard A, McLaughlin JK, Overvad K, Olsen JH. Dietary risk factors for renal cell carcinoma in Denmark. Eur IJ Cancer 1996;32a:673-82.

19. Lindblad P, Wolk A, Bergstrom $R_{y}$ Adami HO. Diet and risk of renal cell cancer: a population-based case-control study. Cancer Epidemiol Biomarkers Prew 1997;6: 215-23.

20. Boeing $\mathrm{H}$, Schlehofer B, Wahrendorf J. Diet, obesity and risk for renal cell carcinoma: results from a case control-study in Germany. Z Ernahrungswiss 1997;36:3-11.

21. Maclure $M$, Willett W. A case-control study of diet and risk of renal adenocarcinoma. Epidemiology 1990;1:430-40. 
22. Van den Brandt PA, Goldbohm RA, Van 't Veer $P$, Volovics $A$, Hermus R, Sturmans F. A large-scale prospective cohort study on diet and cancer in The Netherlands. J Clin Epidemiol 1990;43:285-95.

23. Volovics A, van den Brandt PA. Methods for the analyses of case-cohort studies. Biom $J 1997 ; 39: 159-214$.

24. Van den Brandt PA, Schouten LJ, Goldbolim RA, Dorant E, Hunen PM. Development of a record linkage protocol for use in the Dutch Cancer Registry for Epidemiological Research Irit I Epidemiol 1990;19:553-8.

25. Goldbohm RA, Van den Brandt PA, Dorant E. Estimation of the coverage of Dutch municipalities by cancer registries and PALGA based on hospital discharge data. Tijdschir Soc Gezondheidsz 1994;72:80-4.

26. Goldbohm RA, van den Brandt PA, Brants $\mathrm{HA}$, et al. Validation of a dietary questionnaire used in a large-scale prospective cohort study on diet and cancer. Eur $J$ Clin Nutr 1994:48:253-65.

27. NEVO table. Dutch food composition table 1986-1987. The Hague, The Netherlands: Voorlichtingsbureau woor de Voeding, 1986.

28. Goldbohm RA, Brants HA, Hulshof KF, van den Brandt PA. The contribution of various foods to intake of vitamin $A$ and carotenoids in The Netherlands. Int $J$ Vitam Nutr Res 1998;68:378-83.

29. Konings Ev. A validated liquid chromatographic method for determining folates in vegetables, milk powder, liver, and flour. J AOAC Int 1999;82:119-27.

30. Konings EJ, Roomans HH, Dorant E, Goldbolum RA, Saris WH, wan den Brandt PA. Folate intake of the Dutch population according to newly established liquid chromatography data for foods. Am IClin Nutr 2001;73:765-76.

31. Voorrips LE, Goldbohm RA, Brants HA, et al. A prospective cohort study on antioxidant and folate intake and malle lung cancer risk. Cancer Epidemiol Biomarkers Prev 2000;9:357-65.

32. Dorant E, van den Brandt PA, Goldbohm RA, Hermus RJ, Sturmans F. Agreetnent between interview data and a self-administered questionnaire on dietary supplement use. Eur J Clin Nutr 1994;48:180-8.

33. van Houwelingen KP, van Dijk BA, Hulsbergen-van de Kaa CA, et al. Prevalence of von Hippel-Lindau gene mutations in sporadic renal cell carcinoma: results from the Netherlands cohort study. BMC Cancer 2005;5:57.

34. Eble $\mathbb{J}$, Sauter G, Epstein $J$, Sesterhenn I. World Health Organization Classification of Tumours. Pathology and Genetics. Tumours of the Urinary System and Male Genital Organs. Lyon: IARC Press, 2004.

35. Schoenfeld D. Partial residuals for the proportional hazards regression model. Biometrika 1982;69:239-41.

36. Lin DY, Wei LJ. The robust inference for the Cox Proportional Hazards Model. J Am Stat Assoc 1989;84:1074-8.

37. Wan Dijk BA, Schouten LJ, Kiemeney LA, Goldbohn RA, van den Brandt PA. Vegetable and fruit consumption and risk of renal cell carcinoma: Results from the Netherlands cohort study. Int $J$ Cancer 2005.

38. Goldbohn RA, van 't Veet $P$, van den Brandt PA, et al. Reproducibility of a food frequency questionnaire and stability of dietary habits detemined from five annually repeated measurements. Eur J Clin Nutr 1995;49:420-9.

39. Voorrips LE, Goldbohm RA, Verhoeven DT, et al. Vegetable and fruit consumption and lung cancer risk in the Netherlands Cohort Study on diet and cancer. Cancer Causes Control 2000;11:101-15.

40. Voorrips LE, Goldbohm RA, van Poppel G, Sturmans F, Hermus RJ, van den Brandt PA. Vegetable and fruit consumption and risks of colon and rectal cancer in a prospective cohort study: "The Netherlands Cohort Study on Diet and Cancer. Am J Epidemiol 2000; 152:1081-92. 
41. Schuurman AG, Goldbohm RA, Brants HA, van den Brandt PA. A prospective cohort study on intake of retinol, vitamins $C$ and $E$, and carotenoids and prostate cancer risk (Netherlands). Cancer Causes Control 2002;13:573-82.

42. Verhoeven DT, Assen N, Goldbohna $R A$, et al. Vitamins $C$ and $E$, retinol, betacarotene and dietary fibre in relation to breast cancer risk: a prospective cohort study. Br J Cancer $1997 ; 75: 149-55$.

43. Zeegers MP, Goldbohm RA, van den Brandt PA. Are retinol, vitamin $C$, vitamin E, folate and carotenoids intake associated with bladder cancer risk? Results from the Netherlands Cohort Study. Br J Cancer 2001;85:977-83.

44. Botterweck AA, van den Brandt PA, Goldbohm RA. Vitamins, carotenoids, dietany fiber, and the risk of gastric carcinona: results from a prospective study after 6.3 years of follow-up. Cancer 2000;88:737-48. 
8

General discussion 
Classical epidemiological studies have generally reported weak associations between most risk factors and renal cell carcinoma (RCC); moreover, results of studies on the same risk factors were often equivocal. One way to obtain stronger associations is to reduce heterogeneity at the level of the endpoint. Therefore, in addition to studying the association between risk factors and RCC risk in a classical epidemiological approach, we investigated risk factors in relation to the presence of specific gene mutations, as a more specific endpoint, in a molecular-epidemiological approach. Results from these analyses could ultimately substantiate or lead to hypotheses on the etiology of RCC. Mutations in the von Hippel-Lindau (VHL) gene were chosen as a more specific endpoint since VHL gene mutations are rate-limiting events in the carcinogenesis of clear-cell $\mathrm{RCC}^{1,2}$ and it is the most common genetic aberration. In this chapter the main findings described in this thesis, strengths and limitations, implications of analyses including VFL gene mutations, conclusions and suggestions for further research are discussed.

\section{Main findings}

The relationship between clinical and pathological parameters and the $V H L$ gene mutational status was investigated. Approximately $60 \%$ of all clear-cell tumors presented with one or more $V H L$ gene mutations. Some heterogeneity was present, i.e. in some instances two mutations were observed in one paraffin block, or one paraffin block from a tumor showed no mutations while we did find a mutation in another paraffin block from the same tumor. Regarding clinical parameters, only tumor size appeared to differ by $V H L$ gene mutational status, with larger tumors in case of at least one VHL gene mutation, although this was not statistically significant.

Height was associated with a statistically significantly increased RCC risk only in women. Body mass index and gain in body mass index since age 20 were associated with a statistically significantly increased risk of RCC for men and women. We furthermore assessed whether energy intake and/or physical activity were independent risk factors and whether these factors explained the association between body mass index and RCC. Energy intake was not related to RCC risk, while the association between physical activity and RCC remained unclear. Energy intake and physical activity did not explain the association between body mass index and RCC risk.

Vegetable and fruit consumption were not associated with RCC risk. Most specific botanical groups and individual vegetables and fruits were also not associated with RCC risk. In addition, no association between carotenoid and vitamin intake and RCC risk was observed. Only supplemental vitamin intake appeared to be associated with a slightly increased risk. Stratified analyses based on mutational status showed somewhat higher risks in the group of VHL wildtype tumors (tumors without a mutations in the VHL gene) for alpha-carotene, beta-cryptoxanthin, folate, and vitamin $\mathrm{C}$ and multivitamin supplement intake. Cigarette smoking was no effect modifier for the association between vegetable and fruit consumption and RCC risk or for the 
association between carotenoid and vitamin intake and RCC risk, or risk of $V H L$ mutated or $W H L$ wildtype tumors.

Cigarette smoking itself was associated with an increased RCC risk, especially for men. This is probably the result of a difference in smoking habits between men and women. Risks increased with increasing frequency of cigarettes smoked per day and increasing number of smoking years for men, while the number of cases did not allow us to investigate this for women. We did not find an association of cigarette smoking and specific $V H L$ gene mutations. Risks were the same or slightly higher for wildtype tumors compared to $V H L$ mutated tumors, suggesting cigarette smoking may not cause RCC through $V H L$ gene mutations.

Both hypertension and antihypertensive medication use were associated with a nonstatistically significant increased risk of RCC. Stratified analyses based on the VTHL gene mutational status showed a somewhat higher risk in the group of tumors with a VHL gene mutation for a history of hypertension, while for antihypertensive medication use the risk appeared to be higher in the group of VHL wildtype tumors, suggesting different pathways.

\section{Strengths and limitations}

Both classical epidemiological and molecular epidemiological studies may suffer from different types of bias and confounding. Compared to the classical epidemiological studies, molecular epidemiological studies include molecular data, therefore some additional issues are specifically important, e.g. misclassification of the molecular data. In the following sections, the most important general methodological issues and methodological issues specific to molecular epidemiological studies will be discussed.

\section{General methodological issues}

\section{Measurement of independent variables}

Recall bias is unlikely in this study since the self-administered questionnaire was filled out before cancer was ascertained (all prevalent cancers were excluded from analyses). There are two possible issues that deserve further attention; misclassification of exposure and latency.

First, some misclassification of exposure may have occurred, since exposure was assessed using a self-administered questionnaire. In most instances the effect of the possible presence of this phenomenon could be argued. Height, weight, weight at age 20 , a history of hypertension, antihypertensive medication use and cigarette smoking were all self-reported, as were all other risk factors in this study. This may lead to under-or over-reporting. However, these factors were measured before the diagnosis of $\mathrm{RCC}$ and therefore misclassification is likely to be non-differential with respect to the outcome. Generally, non-differential misclassification leads to attenuated rate ratios ${ }^{3}$. However, in case of variables with more than 2 categories (such as physical activity), 
the result of possible misclassification of exposure is difficult to predict, and may be away from the null for one of the categories. Another possible source of misclassification of exposure is changing habits. In this study population dietary habits were observed to be relatively stable during at least 5 years ${ }^{4}$.

Second, this study was based on 55-69 year olds at baseline because dietary habits (and their contrasts) are stabilized, and such a cohort will yield sufficient cases for meaningful analyses within a reasonable time period ${ }^{5}$. Exposure factors should be measured at a relevant time frame and latency estimates could help determine this timeframe. However, there is uncertainty concerning latency and estimates for latency are seldom reported, because they are difficult to establish. To our knowledge, few studies have reported estimates for latency periods; latency periods are usually estimated at decades e.g. one study estimated latency for smoking and lung cancer at 30 years based on population figures ${ }^{6}$. For RCC, estimates for latency exist only for specific occupational exposures as measured in occupational cohorts. The question then arises whether the incident cancer can be attributed to the investigated factors. It has to be acknowledged that some factors may not be stable or the latency period may not have been adequate, which could have resulted in misclassification and erroneous results. However, most dietary factors appear to be relatively stable in an elderly cohort for a period of at least five years and perhaps even for a decade ${ }^{4}$.

\section{Follow-up}

Loss to follow-up is the primary source of potential selection bias in prospective cohort studies (provided it is differential across determinant strata) ${ }^{5,7,8}$. To minimize the possibility of selection bias, the study area and population in the present cohort study were chosen in a way to ensure sufficient follow-up coverage". The completeness of incident cancer follow-up was estimated to be more than $96 \%{ }^{9}$. The subcohort has been followed up for vital status information biennially by mail, and in case of non-response completed by contacting municipal population registries. Only two male subcohort members were lost to follow-up after 11.3 years of follow-up. It is unlikely that our results are influenced by selection bias because of the high completeness of incident cancer and of person-years follow-up.

\section{Methodological issues specific to molecular epidemiological studies}

\section{Selection bias resulting from tissue collection}

Paraffin block collection to complete information on molecular data for all cases is of great importance in this study. If the collected paraffin blocks are a selection of the blocks in the entire population, observed results may only apply to the investigated population and not to the entire population. Specifically, the absence of tumor tissue, if differential, may lead to selection bias ${ }^{10}$. 
Generally, there are three reasons why tumor tissure may not be available ${ }^{10}$ :

1. In some instances, no material is collected as part of the diagnostic process, e.g. if only low-grade tumors are excised: Overall, a high percentage $(78 \%)$ of patients diagnosed with RCC in the region of the Netherlands covered by the IKL (which is representative for the Netherlands) is treated surgically; although the percentage of surgical procedures was somewhat lower for patients with stage IV $(59 \%)$ or stage X (not assessable) (38\%) tumors (personal communication, IKL, the Netherlands). If this occurred, no histology report or unsuitable samples for our study (e.g. biopsy material only, see also reason 3) would be present. The absence of a histology report in this study may, however, also be the result of record linkage errors or of the incompleteness of PALGA ${ }^{9,11}$. In our study, histology reports, including information on which pathology laboratory holds the paraffin material, were present for most patients $(273 / 337=81 \%)$.

2. Tissue samples may have been unavailable because the tissue was lost or destroyed or the hospital would not release the sample:

Great effort was undertaken to retrieve tumor material from all laboratories with relevant material. Most laboratories were visited to collect paraffin blocks, although some laboratories preferred to mail us the requested paraffin blocks. In the current study, only three pathology laboratories refused to release material (blocks from 10 cases) and for 3 cases material could not be located in the laboratory.

3. The sample preparation is inappropriate for the molecular analysis (e.g. sample is too small, too degraded to assay, lacks normal DNA, or sample preservation method is incompatible with the molecular analytical protocol):

Twenty-four samples were not usable for this study because they were too small, too degraded, or lacked tumor material.

There were no large differences in investigated exposure variables and possible confounding factors between cases with collected paraffin material $(\mathrm{N}=235)$ and cases without collected paraffin material $(\mathrm{N}=102)$. Only the percentage of antihypertensive medication use was different between cases with paraffin blocks collected and those without paraffin blocks ( $26.8 \%$ versus $14.7 \%$, respectively). This difference can probably be ascribed to chance since many variables were tested and none of these variables, including a history of hypertension, showed a statistically significant difference between the groups with and without collected paraffin material. The fact that we were able to retrieve a high proportion of samples, the reported reasons for not being able to collect paraffin material and the absence of differences between cases with or without paraffin material lled us to conclude that our results are not likely to be affected by selection bias.

Ascertainment of endpoint: histological classification

One experienced pathologist revised all slides, resulting in a consistent classification of histology according to the World Health Organization (WHO) classification of Tumours of $2002^{12}$, which is a strength of this study. This information on histology 
could not be extracted from the records of the Netherlands cancer registry or PALGA. The classification of $R C C$ is telatively new and until recently most parenchymal kidney cancers were classified as Grawitz tumors. Most studies on etiological factors for RCC did not incorporate information on the specific histological subtype, while some etiological factors may be linked more closely to certain histological subtypes, as is the case for e.g. smoking and lung cancer ${ }^{13}$.

\section{Ascertainment of endpoint: mutational status}

For the determination of the mutational status of the tumors, a large number of PCR gene based diagnostic tests had to be carried out. We undertook a pilot study to assess PCR-SSCP as a screening tool preceding direct sequencing (chapter 4). In this pilot study, no mutations were missed in the SSCP compared to direct sequencing, and we estimated the upper 95 confidence limit for the chance of missing mutations as a result of using PCR-SSCP as a screening instrument at between $3.7 \%$ and $16.9 \%$. These results led to the decision to use PCR-SSCP as a screening tool. We used 6 primer pairs to cover the VHL gene, which means that for every sample at least 6 PCRs were performed, followed by SSCP analyses. The percentage of observed mutations (61\%) was high in comparison to other studies, which led us to believe that we did not miss large numbers of mutations. We interpreted all observed mutations to be "true" mutations, when the mutations were confirmed in two independent experiments starting from DNA isolated from the paraffin block: PCR-SSCP and direct sequencing.

Surprisingly, discordant cases were found; we observed different mutations in the same paraffin block (13 cases) or the absence versus the presence of a mutation in different paraffin blocks (10 cases) obtained from the same tumor. These results might indicate tumor heterogeneity, while in line with the general opinion clonal $V H L$ mutations were expected. However, others have also reported multiple mutations per primary tumor ${ }^{14-16}$. This observation may be the result of increasing genetic instability leading to additional mutational events in tumor development. All in all, we believe that we obtained valid results for a large population-based study that can be used to investigate the association between risk factors and clear-cell $\mathrm{RCC}$ with or without a $V H L$ gene mutation. However, we are aware of the fact that we investigated the association of risk factors to prevalent and not incident mutations. As a result, we could not determine whether an observed association to a mutation is important in the initiation or promotion phase of tumor development.

\section{Genotype versus phenotype}

The VHL protein (pVHL) and not the VHL gene is eventually important for the tumor suppressing effect. One may argue that the classification into wildtype versus mutated should be made at the protein level (phenotype) and not at the DNA level (genotype), as was done in the current study. Most observed mutations lead to an altered and/or inactive protein. However, this is not the case for silent mutations $(\mathrm{N}=13)$. Also, a mutation in the first 54 codons $(\mathrm{N}=6)$ may not cause the loss of tumor suppressor 
function of the protein, although other functions may be affected. Furthermore, for missense mutations the effect on the protein or on the protein function may not always be clear. This would lead to misclassification at the level of the presence of functional protein, resulting in an underestimation of heterogeneity between samples classified as VHL-mutated or wildtype. However, given the study design and material and methods available, we were only able to investigate the presence of $V H L$ gene mutations and not the presence of (functional) protein. Immunohistochemical staining for pVHL is possible, but the presence of staining is not related to the deletion of $3 p$ gene sequences or VHL mutations ${ }^{17,18}$. Even though absence of functional pVHL is required to lose tumor suppressor function, in molecular carcinogenesis not directly the function but the mutation and type of mutation are of primary interest.

\section{Statistical analyses}

Using a more specific endpoint by definition reduces the number of cases in the analyses. This lack of power may have led to the absence of statistically significant associations, but if a differential association between risk factors and mutational status exists, we still would have expected to find indications for a consistent difference in point estimates based on mutational status.

Investigating heterogeneity of mutational status can be carried out by investigating different case groups (such as cases with a $V H L$ gene mutations or cases without a $V H L$ gene mutation) in comparison to a "control group" or by comparing these different case groups to each other (case-only analyses). The case-only approach is commonly used in molecular-epidemiological studies ${ }^{19-22}$. However, using merely a case-only design is not preferable since no comparison to the population can be made. Therefore, results of a case-only design can only lead to conclusions on the possible existence of mutational heterogeneity, and if a protective effect for mutations is observed, this does not necessarily mean that the risk of cancer is also reduced. This can be illustrated using the data on supplemental vitamin use from chapter 7. Based on case-only comparisons, a nearly significant protective effect of multivitamin supplement intake on $V H L$ gene mutations was observed (OR: $0.22 ; 95 \% \mathrm{Cl}: 0.05-1.02)$. However, compared to the subcohort, the risk for wildtype VHL tumors was increased (RR: $2.51 ; 95 \% \mathrm{Cl}: 1.10$ 5.75 ), while the risk for $K H L$ gene mutated tumors equaled $0.72(95 \% \mathrm{Cl}: 0.22-2.28)$. This shows that the inclusion of a population-based control group in this type of research to show the relation to the population is preferable.

\section{Implications of analyses including $V H L$ gene mutations}

We believed that this molecular epidemiological study could elucidate part of the black box between exposure to risk factors and the not very specific endpoint of RCC. Thus far, however, associations between risk factors and molecular endpoints have not led to more convincing conclusions or clear differential effects. Even for cigarette smoking, we did not find differential results, while cigarette smoking has clearly been shown to 
cause mutations in human DNA, also in tissues not directly exposed to tobacco smoke $^{23}$. Cigarette smoke metabolites have been detected in urine ${ }^{24}$, suggesting exposure of the renal parenchyma to mutagenic cigarette smoke constituents or metabolites. Furthermore, $\mathrm{N}$-nitrosodimethylamine induced tumors were associated with $V H L$ gene mutations (predominantly $\mathrm{G}: \mathrm{C} \rightarrow \mathrm{A}: \mathrm{T}$ transitions) in rats ${ }^{25}$, Unfortunately, the numbers in our analyses were too small to draw conclusions on specific mutations, as well as on the association of the number of cigarettes smoked per day and the number of smoking years and the $V H L$ gene mutational status. This could have given us a more detailed picture of cigarette smoking in relation to the presence of VHL gene mutations. There are also other factors that may explain of the absence of a stronger association between cigarette smoking and the presence of VHL gene mutations. We know that not all persons exposed to cigarette smoke develop cancer, probably as a result of differences in the individual genetic profile of metabolizing enzymes resulting in differences in mutagenicity. Also, other risk factors, besides cigarette smoking may be involved. This may not just be one (unknown) factor but a (unknown) mechanism, reflected in a combination of factors. We may speculate on lipid peroxidation, since this seems to be associated with many risk factors for RCC, e.g. with a high relative body weight, essential hypertension, cigarette smoking and low vitamin $\mathrm{E}$ intake. Byproducts of lipid peroxidation have been shown to react with renal DNA to form adducts which may ultimately lead to DNA mutations, and increased lipid peroxidation was reported to occur more extensively in primary renal cell carcinomas than in surrounding cancer-free tissue ${ }^{26}$. Another possibility may be that cigarette smoking is not implicated in the initiation phase of tumor development, in which presumably $V H L$ gene mutations occur, but in the promotion phase, affecting other (unknown) targets.

The association with hypertension was stronger in RCC patients with VHL gene mutations, while the association between diuretic use and $V H L$ wildtype tumors was stronger, implying the possibility of different pathways for a history of hypertension and diuretic use. Hypertension is associated with increased lipid peroxidation ${ }^{26}$. Diuretic therapy, specifically hydrochlorothiazide use, might be carcinogenic through conversion in the stomach to carcinogenic nitroso-derivatives or through a low-grade carcinogenic effect on the renal tubular cell, its principal target $t^{27}$.

Results were suggestive of higher rate ratios for alpha-carotene, beta-cryptoxanthin, folate and supplemental vitamin $\mathrm{C}$ and multivitamin intake for wildtype VHL tumors. In a study by Nyberg et al., diet was linked to somatic mutations in vivo ${ }^{28}$. The mutant frequency was significantly decreased with higher vitamin C intake, while a U-shaped association between mutant frequency and dietary carotenoid intake was observed ${ }^{28}$. Carotenoid and vitamin intake may only be beneficial in case of oxidative stress, e.g. as a result of cigarette smoking ${ }^{28}$. Unfortunately the numbers in our analyses did not allow us to draw conclusions on analyses stratified by smoking status in $V H L$ mutated and wildtype groups, even though cigarette smoking itself did not seem to be associated with VHL gene mutations. For the total group of RCC cases, we did not observe interaction between carotenoids and vitamins and smoking. 
In general, there is another likely reason for not finding associations between risk factors and $V H L$ gene mutations. Only about $60 \%$ of clear-cell RCC cases present with a $V H L$ gene mutation, while the other $40 \%$ also developed clear-cell $\mathrm{RCC}$, indicating that there have to be other genes or mechanisms that play a role in clear-cell RCC carcinogenesis. For example, repair processes have to fail for a mutation to be sustained and apoptotic mechanisms have to be disabled for a mutated cell to survive. A stepwise accumulation of mutations has been shown to be necessary in e.g. the evolution of colon cancer, which requires biallelic loss of function of several tumor suppressor genes and gain of function of one or more oncogenes ${ }^{29}$. Similarly, to develop clear-cell $\mathrm{RCC}$, more than the two hits to disable both alleles of the VHL gene may be necessary. The investigated model of one or more exposure factors leading to or protecting against $V H L$ gene mutations leading to clear-cell RCC may have been too simplistic.

\section{Conclusions}

In this study we confirmed the positive association of $\mathrm{BMI}$, cigarette smoking, a history of hypertension and antihypertensive medication use with RCC risk. We observed no association with vegetable and fruit consumption and carotenoid and vitamin intake. By specifying the endpoint, based on histology and the presence of VHL gene mutations, we hoped to gain insight into the etiology of RCC. We did not observe clear differential results based on the presence of VHL gene mutations, suggesting that the investigated risk factors may be associated with other genes in the same pathway of $V H L$ or with other pathways. Consistency over studies could not be shown yet, since this is only the third study that included $V H L$ gene mutations as an endpoint, and the three studies are difficult to compare because of differences in design and risk factors studied.

\section{Recommendations for future research}

In future studies, the association between other risk factors such as occupational factors and hormonal factors, and RCC and specifically to $V H L$ gene mutations should be investigated. Occupational exposures may directly cause mutations, while risk factors, such as obesity, a history of oophorectomy, and diabetes, may induce lipid peroxidation, which may ultimately cause mutations ${ }^{26}$. Stratified analyses based on a combined pattern of risk factors, e.g. comparing a group of persons with high expected lipid peroxidation to a group with low expected lipid peroxidation based on their risk factor profile, seems feasible and may lead to new insights.

There are indications that exposures early in life may be particularly relevant in carcinogenesis. It has been shown that a low caloric intake in childhood has been associated with reduced cancer risk (other than cancer related to smoking) ${ }^{30,3 \|}$, although not consistently ${ }^{32,33}$. Early life exposures should be investigated when possible. 
The numbers in our study did not allow for strong conclusions when incorporating VHL gene mutations as a more specific endpoint. Confirmation of our results by other large studies and pooling of existing studies with information on risk factors and VHL gene mutations could lead to more clarity regarding associations between risk factors and $V H L$ gene mutations.

We were not able to investigate the methylation status in this study, yet. This should be further investigated, since samples with hypermethylation of a normally unmethylated promoter region would have been classified as wildtype in our analyses, while this renders the $V H L$ gene transcriptionally inactive. The association between risk factors affecting the presence of methyl donors, such as alcohol consumption and folate intake, and hypermethylation should be investigated.

As discussed before, another gene or set of genes from the same pathway or other pathways may be involved in RCC. Hypoxia inducible factor (HIF) might be interesting, since this factor plays a central role in the hypoxia pathway. It has been shown that HIF is stabilized during hypoxia, in case of a mutated VHL gene (same pathway as under hypoxia), or as a result of receptor-mediated factors, such as growth factors, cytokines and circulatory factors ${ }^{34}$. These growth factors include insulin and insulin-like growth factor- $1^{35}$, factors that have been implicated in cancer development and progression as mitogens that play a pivotal role in regulating cell proliferation, differentiation, and apoptosis ${ }^{36}$. However, another report stated that hypoxia and insulin activate the same set of target genes downstream of HIF, such as vascular endothelial growth factor (VEGF), but that only hypoxia stabilizes HIF, while insulin does not ${ }^{37}$. Other types of genes to be considered for future investigations are genes involved in repair and apoptotic processes and newly discovered genes which appear to be relevant for RCC.

Finally, all persons handle carcinogenic substances differently. Polymorphisms in enzymes that metabolize substrates that are carcinogenic or become carcinogenic in the process of excretion are common ${ }^{38}$. The efficiency of these metabolizing enzymes determines the extent of exposure to a carcinogenic compound and is thus likely to affect cancer risk ${ }^{38}$. Therefore, it would be useful to take polymorphisms in metabolizing enzymes into account, e.g. by including information on CYP1A1 and GSTM1 as risk modifiers for the association between cigarette smoking and RCC risk. 


\section{References}

1. Latif F, Tory $\mathrm{K}$, Gnarra J, et al. Identification of the von Hippel-Lindau disease tumor suppressor gene. Science 1993;260:1317-20.

2. Zbar B, Brauch $\mathrm{H}$, Talmadge $\mathrm{C}$, Linehan M. Loss of alleles of loci on the short arm of chromosome 3 in renal cell carcinoma. Nature 1987;327:721-4.

3. Rothman KJ, Greenland S. Modern Epidemiology. 2nd ed. ed. Philadelphia: LippincottRaven Publishers, 1998.

4. Goldbohm RA, van 't Veer P, van den Brandt PA, et al. Reproducibility of a food freçuency questionnaire and stability of dietary habits determined from five anmually repeated measurements. Eur J Clin Nutr 1995;49:420-9.

5. Van den Brandt PA, Goldbohm RA, Van 't Veer P, Volovics A, Hermus RJ, Sturmans F. A large-scale prospective cohort study on diet and cancer in The Netherlands. I Clin Epidemiol 1990;43:285-95.

6. Weiss W. Cigarette smoking and lung cancer trends. A light at the end of the turnel? Chest $1997 ; 111: 1414-6$.

7. Kelsey JL, Whittemore AS, Evans AS, Thompson WD. Methods in observational epidemiology. second ed. New York: Oxford University Press, 1996.

8. Kleinbaum DG, Kupper $L L$, Morgenstem H. Epidemiologic Research. Principles and quantitative methods. New Y'ork: Van Nostrand Reinhold, 1982.

9. Goldbohm RA, Van den Brandt PA, Dorant E. Estimation of the coverage of Dutch municipalities by cancer registries and PALGA based on hospital discharge data. Tijdschr Soc Gezondheidsz 1994;72:80-4.

10. Hoppin JA, Tolbert PE, Taylor JA, Schroeder JC, Holly EA. Potential for selection bias with tumor tissue retrieval in molecular epidemiology studies. Ann Epidemiol 2002;12:1-6.

11. Van den Brandt PA, Schouten LJ, Goldbohm RA, Dorant E, Hunen PM. Development of a record linkage protocol for use in the Dutch Cancer Registry for Epidemiological Research. Int J Epidemiol 1990;19:553-8.

12. Eble J, Sauter G, Epstein J, Sesterhenn I. World Health Organization Classification of Tumours. Pathology and Genetics. Tumours of the Urinary System and Male Genital Organs. Lyon: IARC Press, 2004.

13. Blot WI, Fraumeni JF. Cancers of the long and pleura. In: Schottenfeld D, Fraumeni JF, eds. Cancer Epidemiology and Prevention. 2nd ed. ed. New York: Oxford University Press, 1996.

14. Brauch $H$, Weirich $G$, Brieger $J$, al. VHL alterations in human clear cell renal cell carcinoma: association with advanced tumor stage and a novel hot spot mutation. Cancer Res $2000 ; 60: 1942-8$.

15. Ma $X$, Yang $K$, Lindblad $P$, Egevad L, Hemminki $K$. VHL gene alterations it renal cell carcinoma patients: novel hotspot or founder mutations and linkage disequilibrium. Oncogene $2001 ; 20: 5393-400$.

16. Yang $\mathbb{K}$, Lindblad $P$, Egevad L, Hemminki $K$. Novel somatic mutations in the VHL gene in Swedish archived sporadic renal cell carcinomas [In Process Citation]. Cancer Lett $1999 ; 141: 1-8$.

17. Hughson MD, He Z, Liu S, Coleman J, Shingleton WB. Expression of HIF-1 and ubiquitin in conventional renal cell carcinoma: relationship to mutations of the won Hippel-Lindau tumor suppressor gene. Cancer Genet Cytogenet 2003; 143:145-53.

18. Los M, Jansen GH, Kaelin WG, Lips CJ, Blijham GH, Voest EE. Expression pattern of the von Hippel-Lindau protein in human tissues. Laboratory investigation a journal of technical methods and pathology 1996;75:231-8. 
19. Hemminki $K$, Jiang $Y$, Ma X, Yang $K$, Egevad L, Lindblad P. Molecular epidemiology of VHL gene inutations in renal cell carcinoma patients: relation to dietary and other factors. Carcinogenesis 2002;23:809-15.

20. O'Brien $\mathrm{H}_{3}$ Matthew $\mathrm{JA}$, Gee $\mathrm{JM}$, et al. $\mathrm{K}$-ras mutations, rectal crypt cells proliferation, and meat consumption in patients with left-sided colorectal carcinoma. Eur J Cancer Prev $2000 ; 9: 41-7$

21. Kampman $\mathrm{E}_{3}$ Voskuil DW, wan Kraats AA, al. Animal products and K-ras codion 12 and 13 mutations in colon carcinomas. Carcinogenesis $2000 ; 21: 307-9$.

22. Martinez ME, Maltzman T, Marshall JR, et al. Risk factors for Ki-ras protooncogene mutation in sporadic colorectal adenomas. Cancer Res 1999;59:5181-5.

23. Phillips DH. Smoking-related DNA and protein adducts in human tissues. Carcinogenesis $2002 ; 23: 1979-2004$.

24. Hecht SS. Human urinary carcinogen metabolites: biomarkers for investigating tobacco and cancer. Carcinogenesis 2002;23:907-22.

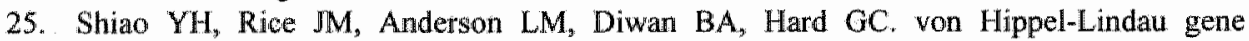
mutations in $\mathrm{N}$-nitrosodimethylamine-induced rat renal epithelial tumors [see comments] I Natl Cancer Inst 1998;90:1720-3.

26. Gago-Dominguez M, Castelao JE, Yuan JM, Ross RK, Yu MC. Lipid peroxidation: a novell and unifying concept of the etiology of renal cell carcinoma (United States). Cancer Causes Control 2002;13:287-93.

27. Grossman $\mathrm{E}$, Messerli FH, Goldbourt $U$. Does diuretic therapy increase the risk of renal cell carcinoma? [editorial]][see comments]. Am J Cardiol 1999;83:1090-3.

28. Nyberg $\mathrm{F}$, Hou SM, Pershagen $\mathrm{G}$, Lambert B. Dietary fruit and vegetables protect against somatic mutation in vivo, but low or high intake of carotenoids does not. Carcinogenesis $2003 ; 24: 689-96$

29. Kinzler KW, Vogelstein B. Colorectal tumors. In: Vogelstein B, Kinzler KW, eds. The genetic basis of human cancer. New York: McGraw-Hill, 1998:565-87.

30. Frankel S, Gunnell DJ, Peters TJ, Maynard M, Davey Smith G. Childhood energy intake and aclult mortality from cancer: the Boyd Orr Cohort Study. Bmj 1998;316:499-504.

31. Dirx MJ, van den Brandt PA, Groldbohm RA, Lumey LH. Energy restriction early in life and colon carcinoma risk: results of The Netherlands Cohort Study after 7.3 years of follow-up. Cancer 2003;97:46-55.

32. Dirx MJ, wan den Brandt PA, Goldbohm RA, Lumey LH. Energy restriction in childhood and adolescence and risk of prostate cancer: results from the Netherlands Cohort Study. An Epidemiol 2001;154:530-7.

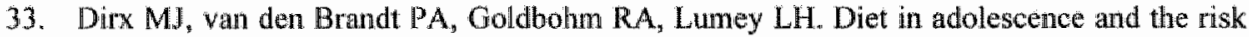
of breast cancer: results of the Netherlands Cohort Study. Cancer Causes Control 1999;10:189-99.

34. Bilton RL, Booker GW. The subtle side to hypoxia inducible factor (HIFalpha) regulation. Eur J Biochem 2003;270:791-8.

35. Zelzer $\mathrm{E}$, Levy $\mathrm{Y}$, Kahana $\mathrm{C}$, Shillo $\mathrm{BZ}$, Rubinstein $\mathrm{M}$, Cohen $\mathrm{B}$. Insullin induces transcription of target genes through the hypoxia-inducible factor HIF-lalpha/ARNT. Embo J 1998; 17:5085-94.

36. Yu H, Rohan $\mathrm{T}$. Role of the insulin-like growth factor family in cancer development and progression. J Natl Cancer Inst 2000;92:1472-89.

37. Yim $S_{\text {, }}$ Choi SM, Choi $Y$, Lee $N$, Chung $J_{3}$ Park H. Insulin and hypoxia share common target genes but not the hypoxia-inducible factor-lalpha. J Biol Chem 2003;278:38260-8.

38. Parkinson A. Biotransformation of Xenobiotics. In: Klaasen CD, ed. Casarett and Doull's toxicology: the basic science of poisons. 5 ed. New York: McGraw-Hill, 1996:1 $13-86$. 
Summary 
Kidney cancer is the ninth most common cancer in the European Union. Incidence and mortality rates are higher in developed regions and are approximately twice as high for men as for women. The 5-year survival is approximately $55 \%$. Kidney cancer includes cancer of the renal parenchyma (renal cell carcinoma ( $\mathrm{RCC}$ )) and cancer of the renal pelvis. These types of cancer differ with respect to anatomical location, type of cell from which these evolve (parenchymal cells versus urothelial cells, respectively) and their association with risk factors.

We confined our research to cancer of the renal parenchyma, RCC, which can be subdivided into several histological types. The most common histological subtype is clear-cell or conventional RCC, which accounts for approximately $75 \%$ of renal neoplasms in surgical series.

Aberrations in the von Hippel-Lindau (VHL) gene have been shown to be a common, early and distinct event in the development of clear-cell RCC. The $V H L$ gene is a tumor suppressor gene, located on the short arm of chromosome 3 (3p25-26), and it is composed of three exons. Since the $V H L$ gene is a tumor suppressor gene, both alleles need to be affected before the function will be lost. Biallelic $V H L$ gene defects are observed in approximately $75 \%$ of sporadic clear-cell RCC. The human VHL gene encodes two VHL proteins: pVHL30 and pVHL19. Both proteins suppress tumor formation. Loss of $\mathrm{pVHL}$ creates an environment favorable for tumor growth.

The association of many risk factors with RCC risk has been investigated, but only cigarette smoking, obesity, a history of hypertension and use of diuretics were consistently linked to RCC risk. Although consistent, risks were not very high.

Generally, little attention is spent on the endpoint. However, RCC is a heterogeneous endpoint, i.e. there are several histological subtypes and sporadic mutations may be present or absent. Stratified analyses based on histology and the mutational status of a tumor may lead to additional insight in the carcinogenesis process.

In this thesis we investigated several hypotheses on the association between risk factors and the risk of RCC and in some instances with clear-cell RCC and the presence of mutations in the VHL gene within the setting of the Netherlands Cohort Study on diet and cancer (NLCS). The NLCS is a prospective cohort study, which started in September 1986 . The cohort included 120,852 men and women, aged 55-69 years at the beginning of the study. All participants completed a self-administered questionnaire on dietary habits (food-frequency questionnaire). lifestyle, personal medical history, family history of cancer and demographic data. The study was designed as a casecohort study, using all cases, while the person-time accumulated in the entire cohort was estimated using a random sample of 5,000 men and women (subcohort). Follow-up for incident cancer has been established by annual record linkage to the Netherlands cancer registry and PALGA, a national database of pathology records. After 11.3 years of follow-up, 337 incident histologically confirmed epithelial cancer cases were observed.

In chapter 2, we found BMI to be an independent risk factor for RCC (rate ratio (RR): $1.07 ; 95 \% \mathrm{CI}: 1.02-1.12$ per $1 \mathrm{~kg} / \mathrm{m}^{2}$ increment). A RR higher than 1 means that there 
is an association with an increased risk (lower than 1 : reduction of risk); the observed association is unlikely to be a chance result if the $95 \%$ CI does not include 1). Height in women (RR: $1.23 ; 95 \% \mathrm{Cl}: 1.02-1.46$ per $5 \mathrm{~cm}$ increment) but not in men (RR: 0.97 ; 95\% CI: 0.84-1.13 per $5 \mathrm{~cm}$ increment), and weight both in men (RR: $1.09 ; 95 \% \mathrm{CI}$ : 0.98-1.20 per $5 \mathrm{~kg}$ increment) and women (RR: $1.11 ; 95 \% \mathrm{CL}: 1.01-1.23$ per $5 \mathrm{~kg}$ increment), also increased $\mathrm{RCC}$ risk. BMI gain since age 20 years increased the risk of RCC (RR: $1.06 ; 95 \%$ CI: 1.01-1.10). Energy intake was not associated with RCC, while the association of physical activity and $\mathrm{RCC}$ remains unclear. Furthermore, energy intake and physical activity did not explain the association of BMI and $\mathrm{RCC}$.

We also observed that neither total vegetable and fruit consumption, nor the consumption of specific botanical groups of vegetables or fruits nor individual vegetables or fruits consumption were associated with a decreased RCC risk. Furthermore, there were no indications for a modifying effect by cigarette smoking. BMI or a history of hypertension (chapter 3 ).

To be able to investigate risk factors with the more specific endpoint of the presence of von Hippel-Lindau (VHL) gene mutations, we collected paraffin embedded tumor material from the large series of incident RCC cases in this cohort from 51 pathology laboratories, which has been described in chapter 4. Approval was obtained from the medical ethical committees of Maastricht University, PALGA, and the Netherlands cancer registry. We were able to identify the location of paraffin material for 273 cases out of the 337 incident cases. For 251 of 273 cases we collected paraffin blocks. After revision by a pathologist, tumor DNA from 235 cases was available for further analysis.

We observed at least one VHL gene mutation in $61 \%$ of the clear-cell RCC tumors; most were truncating mutations. No differences were observed in nuclear grade, TNM distribution or stage for tumors with or without a $V H L$ gene mutation. $V H L$ mutated tumors were on average $72.7 \mathrm{~mm}$ in size compared to a mean tumor size of $65.3 \mathrm{~mm}$ for wildtype VHL tumors. However, this difference was not statistically significant (chapter 4).

Cigarette smoking is a known risk factor for $\mathrm{RCC}$. Cigarette smoke metabolites have been shown to cause mutations in human. DNA, which is not restricted to tissues directly exposed to tobacco smoke. In chapter 5 we investigated the association of cigarette smoking to RCC and to $V H L$ gene mutations in clear-cell RCC. For men, RRs for total RCC were $1.52(95 \% \mathrm{Cl}: 0.89-2.59)$ and $2.07(95 \% \mathrm{CI}: 1.20-3.56)$ for ex- and current smokers compared to never smokers, respectively. Estimates for women equaled $0.95(95 \% \mathrm{CI}: 0.57-1.59)$ and $1.37(95 \% \mathrm{CI} 0.87-2.16)$, respectively. When stratified for $V H L$ mutation status, RRs for current smokers compared to never smokers were 2.34 (95\% CI: $0.79-6.94)$ and 2.95 (95\% CI: 0.65-13.28) for VHL gene mutated and $V H L$ wildtype tumors, respectively, for men. For women, these estimates were 0.82 (95\% CI: 0.35-1.93) and 2.04 (95\% Cl: 0.94-4.45), respectively. Cigarette smoking was associated with RCC risk in men, but cigarette smoking was not specifically associated with VHL gene mutations, irrespective of sex. These results suggest that smoking may be associated with RCC risk, independent of VHL gene mutations. 
A history of hypertension and use of antihypertensive medication have been associated to $\mathrm{RCC}$ risk, although, it remains unclear whether the increased risk is caused by hypertension or the medication. Hypertension (RR: 1.22; 95\% CI: 0.94-1.58) and use of antihypertensive medication (RR: $1.14 ; 95 \% \mathrm{Cl}: 0.85-1.52$ ) were associated with a slightly increased overall RCC risk in our study (chapter 6). A history of hypertension was associated with a non-significantly increased risk of clear-cell RCC with VHL gene mutations: (RR: $1.34 ; 95 \% \mathrm{CI}: 0.87-2.07$ ), and was not associated with the risk of clear-cell RCC without VHL gene mutations (RR: 0.88 ; 95\% CI: 0.51-1.53). Use of diuretics (a type of antihypertensive) was not associated with $V H L$ gene mutated clearcell RCC (RR: $0.91 ; 95 \%$ CI: $0.45-1.81$ ), but it was associated with clear-cell RCC without VHL gene mutations (RR: $2.11 ; 95 \% \mathrm{Cl}: 1.16-3.83$ ). These results imply the possibility of different pathways for a history of hypertension and diuretic use, although false-positive findings as a result of multiple testing and small numbers cannot be excluded.

Dietary carotenoid and vitamin intake were not (inversely) associated with overall RCC risk (chapter 7). Supplemental vitamin E, AD and multivitamin use were associated with a non-statistically significantly increased risk. Results were suggestive of higher RRs for wildtype VHL tumors with alpha-carotene, beta-cryptoxanthin, folate and supplemental vitamin $\mathrm{C}$ and multivitamin intake.

Overall, in this study, we confirmed the positive association of BMI, cigarette smoking, a history of hypertension and antihypertensive medication use with RCC risk. We observed no association with vegetable and fruit consumption and carotenoid and vitamin intakes. We did not observe clear differential results between risk factors and the presence of $V H L$ gene mutations, even though VHL gene mutations are an early, common and distinct feature of clear-cell RCC. One possible explanation may be that risk factors play a role in the promotion and not the initiation phase of renal carcinogenesis. Hypermethylation of the promoter area of the VHL gene may also render the $V H L$ gene transcriptionally inactive, which should be further investigated. Furthermore, only about $60 \%$ of clear-cell RCC cases present with a $V H L$ gene mutation. This indicates that there are other genes or mechanisms that have to play a role in clear-cell carcinogenesis, possibly similar to colon cancer, in which biallelic loss of function of several tumor suppressor genes and gain of function of one or more oncogenes is required.

Future research should investigate more risk factors and/or combine risk factors according to possible mechanisms. The associations investigated in this thesis should, however, be tested in other large studies. Pooling of our results with information on risk factors and $V H L$ gene mutations from other studies may lead to more firm conclusions. Finally, other genes, such as genes involved in the angiogenesis pathway, genes that play a role in repair processes, or genes involved in apoptosis should also be considered for investigation in a molecular-epidemiological approach if there are reports on mutations or promoter hypermethylation in $\mathrm{RCC}$. 
Samenvatting 
Nierkanker is het negende meest voorkomende type kanker in de Europese Unie. Incidentie en mortaliteitsratio's zijn hoger in de ontwikkelde landen en zijn ongeveer 2 keer zo hoog voor mannen dan vrouwen. De 5-jaarsoverleving bedraagt ongeveer $55 \%$. Vaak wordt onder nierkanker niet alleen kanker van het nierparenchym, maar ook kanker van het nierbekken gerekend, maar kanker van het nierbekken is anders wat betreft anatomische locatie, het type cel waaruit de kanker zich ontwikkelt (urotheel cellen versus parenchym cellen) en de beschreven associaties met risicofactoren.

We hebben ons in ons onderzoek beperkt tot kanker van het parenchym, in het vervolg met nierkariker angeduid, dat verder onderverdeeld kan worden in verschillende histologische subtypes. Het meest voorkomende histologisch subtype is heldercellige nierkanker, wat in ongeveer $75 \%$ van niertumoren in chirurgische series vastgesteld wordt.

Afwijkingen in het von Hippel-Lindau (VHL) gen zijn een vroege, veel voorkomende en karakteristieke gebeurtenis in de ontwikkeling van heldercellige niertumoren. Het VHIL gen is een tumor suppressor gen, dat zich bevindt op de korte arm van chromosoom 3 (3p25-26), en omvat 3 exonen. In het geval van een tumor suppressor gen moeten beide allelen aangedaan zijn voordat de functie verloren gaat. Dit wordt gevonden in ongeveer $75 \%$ van de sporadische (niet erfelijke) heldercellige niertumoren. Mutaties leiden meestal tot een verkort, inactief eiwit. Het wildtype $V H L$ gen kan twee eiwitten opleveren: pVHL30 en pVHL 19. Beide eiwitten onderdrukken tumorgroei. Verlies van pVHL zorgt voor een omgeving die gunstig is voor tumorgroei.

De associatie tussen verschillende risicofactoren en het risico van nierkanker is al eerder onderzocht, maar alleen roken, overgewicht, hoge bloeddruk in de voorgeschiedenis en het gebruik van diuretica (medicijnen die voorgeschreven worden om de hoge bloeddruk te verlagen) werden consistent in verband gebracht met het risico van nierkanker. De gerapporteerde de risico's waren echter niet heel hoog.

Vaak wordt in epidemiologische analyses weinig aandacht geschonken aan de specificiteit van het eindpunt. Nierkanker is echter een heterogeen eindpunt omdat er verschillende histologische subtypen zijn, welke gekarakteriseerd kunnen zijn door de aan- of afwezigheid van specifieke mutaties. Gestratificeerde analyses gebaseerd op histologie en op de mutatie status van een tumor kunnen leiden tot nieuwe inzichten in het ontstaansproces van nierkanker.

In dit proefschrift hebben we verschillende hypothesen betreffende het verband van risicofactoren en de kans op nierkanker onderzocht. Indien gegevens ten aanzien van de aanwezigheid van mutaties in het $V H L$ gen in heldercellige niertumoren op dat moment bekend waren, dan zijn deze ook geanalyseerd als een specifieker eindpunt. Dit onderzoek is uitgevoerd binnen de Nederlandse cohort studie naar voeding en kanker (NLCS). De NLCS is een prospectieve cohort studie, welke in september 1986 gestart is. In deze cohort studie zijn 120,852 mannen en vrouwen geüncludeerd die op dat moment 55-69 jaar oud waren. Alle deelnemers hebben een vragenlijst over voedingsgewoonten (voedselfrequentie vragenlijst), leefstijlfactoren, persoonlijke 
medische geschiedenis, vragen over het voorkomen van kanker in de familie en demografische gegevens ingevuld. Het onderzoek is een zogenaande case-cohort studie, waarin alle cases worden opgenomen die in het complete cohort ontstaan, terwijl de persoonstijd in het volledige cohort geschat word aan de hand van de opgebouwde persoonstijd in het subcohort (willekeurige steekproef) wan 5,000 mannen en vrouwen. Incidente kanker werd vastgesteld door een jaarlijkse koppeling met de Nederlandse kankerregistratie en PALGA, een landelijke database van pathologie rapporten. $\mathrm{Na} 11.3$ jaar waren er 337 incidente, histologisch bevestigde, epitheliale kanker.

In hoofdstuk 2 beschrijven we dat body mass index (BMI: gewicht in kilogram / lengte in meter $^{2}$ ) een onafhankelijke risicofactor is voor nierkanker (risico ratio (RR): 1.07; $95 \%$ betrouwbaarheidsinterval (BI): $1.02-1.12$ per $1 \mathrm{~kg} / \mathrm{m}^{2}$ toename). Een RR groter dan 1 betekend dat er een verhoging yan het risico is (kleiner dan 1: verlaging van het risico); indien het getal 1 niet binnen het $95 \%$ BI valt is het onwaarschijnlijk dat de gevonden associatie door toeval kan worden verklaard. Lengte voor vrouwen (RR: 1.23; 95\% BI: $1.02-1.46$ per $5 \mathrm{~cm}$ toename), maar niet voor mannen (RR: $0.97 ; 95 \%$ BI: $0.84-1.13$ per $5 \mathrm{~cm}$ toename) en gewicht in mannen (RR: $1.09 ; 95 \%$ BI: $0.98-1.20$ per $5 \mathrm{~kg}$ toename) en vrouwen (RR: $1.11 ; 95 \% \mathrm{BI}: 1.01-1.23$ per $5 \mathrm{~kg}$ toename) verhoogden het risico van nierkanker. Ook een toename in body mass index sinds 20 jarige leeftijd verhoogde de kans op nierkanker (RR: 1.06; 95\% BI: 1.01-1.10). Energie-inname was niet geassocieerd met nierkanker, terwijl de associatie tussen fysieke activiteit en nierkanker nog onduidelijk blijft. Energie-inname en fysieke activiteit verklaarden het gevonden verband tussen BMI en nierkanker niet.

In hoofdstuk 3 hebben we gevonden dat noch de totale groente en fruitconsumptie, noch de consumptie van groenten en fruit geclassificeerd in botanische subgroepen, noch de consumptie van individuele soorten groenten en fruit geassocieerd waren met een verlaagd risico op nierkanker. Daarbij vonden we geen indicatie voor een modificerend effect door roken, BMI of een hoge bloeddruk in de voorgeschiedenis.

Om de associatie van risicofactoren en het specifieke eindpunt "de aanwezigheid van von Hippel-Lindau (VHL) gen mutaties" te kunnen onderzoeken, hebben we paraffineingebed tumormateriaal verzameld in 51 pathologielaboratoria. Dit is beschreven in hoofdstuk 4. Hiervoor hadden we toestemming van de medisch ethische commissies van de Universiteit Maastricht, PALGA en de Nederlandse Kankerregistratie verkregen. We waren in staat de locatie van het paraffine materiaal te achterhalen voor 273 van de 337 cases. Van 251 patiënten konden we ook daadwerkelijk paraffineblokjes verzamelen. Na revisie door éen patholoog, bleek dat het tumormateriaal van 235 cases beschikbaar was voor verdere analyse.

Gebruik makend van PCR-SSCP gevolgd door directe sequencing, vonden we in $61 \%$ van de heldercellige niertumoren $V H L$ gen mutaties; de meeste mutaties waren truncerende mutaties. We vonden geen verschillen in nucleaire graad, TNM verdeling of stadium tussen tumoren met of zonder VHL gen mutaties. Tumoren met VHL gen mutaties waren gemiddeld $72.7 \mathrm{~mm}$ groot, terwijl de gemiddelde tumorgrootte van 
wildtype VHL tumoren $65.3 \mathrm{~mm}$ was. Dit verschil in grootte was niet statistisch significant (hoofdstuk 4).

Roken is een bekende risicofactor voor nierkanker. Het is aangetoond dat metabolieten uit sigarettenrook mutaties veroorzaken in humaan DNA en dat dit niet alleen plaats vindt in direct blootgestelde weefsels. In hoofdstuk 5 hebben we de associatie tussen roken en nierkanker en $V H L$ gen mutaties in heldercellige niertumoren onderzocht. RRs voor totaal nierkanker voor mannen waren 1.52 ( $95 \%$ BI: 0.89-2.59) en 2.07 (95\% BI: 1.20-3.56) voor ex- en huidige rokers, respectievelijk, in vergelijking tot nooit rokers. De schattingen voor vrouwen bedroegen respectievelijk 0.95 (95\% BI: 0.57 1.59) en 1.37 (95\% BI: 0.87-2.16). Voor mannen waren de RRs voor huidige rokers in vergelijking tot nooit rokers respectievelijk 2.34 (95\% BI: 0.79-6.94) en 2.95 (95\% $\mathrm{BI}$ : $0.65-13.28$ ) voor $V H L$ gen gemuteerde en $V H L$ wildtype tumoren. Voor vrouwen waren deze schattingen respectievelijk $0.82(95 \%$ BI: $0.35-1.93)$ en 2.04 (95\% BI: 0.94-4.45). Roken was geassocieerd met nierkanker bij mannen, maar niet specifiek met $V H L$ gen mutaties noch bij mannen, noch bij vrouwen. Dit suggereert dat roken geassocieerd zou künnen zijn met nierkanker, maar dat dit onafhankelijk van $V H L$ gen mutaties verloopt.

Hoge bloeddruk in de voorgeschiedenis en het gebruik van medicatie tegen een hoge bloeddruk zijn gerelateerd aan de kans op nierkanker, maar het is nog onduidelijk welke van deze twee factoren het verhoogde risico veroorzaakt. Een hoge bloeddruk (RR: 1.22 ; 95\% BI: 0.94-1.58) en het gebruik van medicatie tegen een hoge bloeddruk (RR: 1.14 ; 95\% BI: 0.85-1.52) waren geassocieerd met een verhoogd risico op het ontwikkelen van nierkanker, maar dit was statistisch niet significant (hoofdstuk 6). Hoge bloeddruk was geassocieerd met een niet statistisch significant verhoogd risico van heldercellige niertumoren met een $V H L$ gen mutatie (RR: $1.34 ; 95 \% \mathrm{BI}: 0.87-$ 2.07), en vertoonde geen relatie met de kans op heldercellige niertumoren zonder $V H L$ gen mutaties (RR: 0.88; 95\% BI: 0.51-1.53). Diureticagebruik was niet geassocieerd met $V H L$ gen gemuteerde heldercellige niertumoren (RR: 0.91; 95\% BI: 0.45-1.81), maar wel met heldercellige niertumoren zonder $V H L$ gen mutaties (RR: $2.11 ; 95 \% \mathrm{BI}$; 1.16-3.83). Deze resultaten impliceren dat er mogelijk verschillende routes zijn, via welke hoge bloeddruk en diuretica gebruik leiden tot niertumoren, hoewel foutpositieve bevindingen als gevolg van het uitvoeren vat multipele testen en kleine aantallen niet uit te sluiten zijin.

De inname van carotenoiden en vitaminen uit voeding was niet geassocieerd met niertumoren (hoofdstuk 7). Het gebruik van vitamine $\mathrm{E}, \mathrm{AD}$ en multivitamine supplementen was geassocieerd met een niet statistisch significant verhoogd risico op nierkanker. De resultaten waren suggestief voor hogere RRs in het geval van wildtype VHL tumoren in het geval van alfacaroteen, betacryptoxanthine, follimzuur, vitamine C supplement en multivitamine supplement gebruik.

Deze studie bevestigt de positieve associatie van BMI, roken, een hoge bloeddruk in de voorgeschiedenis en het gebruik van medicatie tegen een hoge bloeddruk en nierkanker. We vonden geen associatie van groente en fruit consumptie en 
carotenoilden en vitamine inname en nierkanker. We vonden geen overtuigende verschillen in de associatie tussen risicofactoren en tumoren met en zonder $V H L$ gen mutaties, ondanks dat VHL gen mutaties gezien worden als een vroege gebeurtenis in de ontwikkeling van heldercellige niertumoren. Een mogelijke reden voor deze bevindingen zou kunnen zijn dat deze risicofactoren een rol in de promotiefase en niet in de initiatiefase van de ontwikkeling van niertumoren een rol spelen. Hypermethylering van de $W H L$ gen promoter zorgt er ook voor dat het gen niet afgelezen wordt en er dus geen eiwit gevormd wordt; daarom zou dit ook onderzocht moeten worden. Bovendien is het zo dat in slechts $60 \%$ van de heldercellige niertumoren $V H L$ gen mutaties worden gevonden. Dit is een indicatie dat andere genen of mechanismen een rol moeten spelen in de ontwikkeling van heldercellige nierkanker, zoals ook het geval is in colorectaal tumoren, waarin verschillende tumor suppressor genen uitgeschakeld en een of meer oncogenen aangeschakeld moeten zijn. In toekomstig onderzoek zouden andere risicofactoren en/of combinaties van risicofactoren gebaseerd op mogelijke mechanismen verder onderzocht moeten worden. Ook zouden we onze resultaten graag bevestigd of ontkracht zien door andere grote studies. Resultaten uit deze studies en onze resultaten zouden dan ook samen genomen kunnen worden voor een zogenaamde gepoolde analyse, wat zou kunnen leiden tot duidelijkere conclusies. Tenslotte, zouden andere genen die betrokken zijn bij het proces van angiogenese (de vorming van nieuwe bloedvaten), genen die een rol spelen in DNA-schadeherstelprocessen en genen die een rol spelen in apoptose (geprogrammeerde celdood) ook overwogen moeten worden voor verder moleculaireepidemiologisch onderzoek indien er aanwijzingen zijn voor mutaties of promoter hypermethylering in niertumoren. 
Dankwoord 
Hier wil ik graag alle personen die direct of indirect betrokken zijn geweest bij het tot stand komen van mijn proefsclmift bedanken.

Allereerst wil ik mịn promotieteam graag bedanken: Leo, je hebt me vaak bijgestan. met je vakinhoudelijke kennis en steun, niet alleen ten aanzien van de grote lijnen maar ook bij de dagelijkse aangelegenheden. Dit heb ik altijd zeer gewaardeerd. Bedankt voor de inspirerende werking die van je uitging en ik hoop dat we contact kunnen houden! Piet, jou wil ik graag bedanken voor je vertrouwen in me, je scherpte ten aanzien van alles, en het in de gaten houden van tijdsplanning en de hoofdlijnen. Jack, hartstikke bedankt voor het mogelijk maken van dit onderzoek in je lab en fijn dat je hierbij als promotor betrokken was.

Dit alles was niet mogelijk geweest zonder gegevens uit de Nederlandse cohortstudie naar voeding en kanker (NLCS). Daarom een woord van dank aan Piet en Sandra, die deze studie hebben opgezet, én natuurlijk aan de deelnemers die ooit de moeite hebben genomen om de vragenlijst in te vullen en deze samen met hun teemagelknipsels op te sturen. In dit onderzoek zijn de koppelingen van de NLCS aan de Nederlandse kankerregistratie en PALGA van groot belang geweest. De pathologielaboratoria wil ik graag bedanken voor hun medewerking bij het verzamelen van tumormateriaal. Een prospectieve cohortstudie vergt nogal wat onderhoud, dus bij dezen wil ik gratg. iedereen bedanken die in het verleden of het heden hier een bijdrage aan geleverd heeft. De jaarlijkse NLCS-dag waarop de collega's uit Zeist en Maastricht bij elkaar kwamen was niet alleen nuttig, maat ook zeer gezellig. Sandra, dankzij jouw nuttige opmerkingen zijn mijn artikelen vaak beter geworden. Elleny, eindelijk mag ik dan ook!

Het laboratoriumwerk was met name het werk van Kjeld en Hanneke. Kjeld, fijn dat jij me in deze praktische zaken wegwijs hebt willen maken. Hierdoor kreeg ik goed zicht op de praktische kant van dit verhaal en ik vond het erg leuk dat ik daardoor een deel van de analyses zelf heb kunnen uitvoeren. Een speciaal woord van dank is ook op zijn plaats voor Egbert Oosterwijk die me zeer geholpen heeft bij de inhoudelijke moleculaire aspecten van dit werk. Ook wil ik de andere medewerkers wan het lab Urologie graag bedanken voor hun gezelligheid en interesse als ik Nijmegen was. Verder wil ik ook Christina graag bedanken voor haar bijdragen en persoonlijke interesse. Bart, jou wil ik graag bedanken voor je enthousiasme en je betrokkenheid, die me hebben gesteund in mijn keuze voor het epidemiologisch onderzoek. Ik vind het erg leuk dat je bij mijn werk betrokken bent gebleven en ik hoop dat dit nog lang zo mag blijwen. 
Ik wil alle (ex-)collega's van Epidemiologie graag bedanken voor de gezellige werksfeer. Natuurlijk zijn er altijd een aantal personen die op verschillende momenten wat extra voor me hebben betekend, dus Mirian (fijn dat je mijn paranimf wil zijn), Margreet, Nicole W, Nicole J, Lore, Maartje, Wonneke, Kim, Stefan, Janneke en het Nijmegen-clubje (Patty, Adri, Luc, Bas, Bianca en Audrey): bedankt! Speciale dank ook aan Nathalie, Ria en Yvonne van het secretariaat voor alle hulp en adviezen en aan Harry en Jos voor hun hulp bij computerproblemen.

Verder wil ik de gemengde recreanten van BC Kimbria graag bedanken. Ik kon me elke donderdagavond heerlijk uitleven en ik heb jullie persoonlijke interesse bij de gezellige borrels na afloop zeer gewaardeerd!

Ik wil mijn vrienden graag bedanken voor hun steun en interesse:

- Mijn vrienden uit Nijmegen: Eva (fijn dat je mijn paranimf wil zijn), Maureen \& René, Sui \& Sjaak, Marieke \& Richard, Paco, Karlijn, Christiaan \& Maike, en Kachung (bedankt voor het maken van deze fantastische omslag!) \& Paulien.

- Mijn vrienden uit "s-Hertogenbosch: Michel, Robert, Marloes \& Stan, en Ramon.

- Maastrichtse vrienden uit Nijmegen: Wendy \& Erik, Etienne, en Meyke.

- Door mijn buitenlanse reizen heb ik ook vrienden gemaakt in:

- The USA: Joe \& Phyllis, Helen and Amy: Thank you for being my friend!

- Guatemala: Byron \& Nidia, Xiomara \& Mirko, Anaité, y Mayari \& Milo: me siento feliz de conocer a vosotros y espero que continuamos el contacto! Un abrazo grande.

Rik, ik had je in veel van de bovenstaande groepen mensen wel een plaatsje kunnen geven, bijvoorbeeld bij de collega's die wat extra voor me hebben betekend en bij mijn vrienden. Ik vond onze lunchwandelingen en onze gitaaravondjes altijd erg gezellig en ik vind het dan ook erg leuk dat ik je hier ook kan bedanken voor je steun als "mijn vriend", Bedankt!

Ik ben ook dankbaar voor de interesse en steun van mijn familie en ik ben blij dat ik Mieke, Marylène, Marieke \& Meindert, Chantal \& Kees-Jan, en Nienke en hun families daar ook bij mag rekenen.

Last but not least: pap, mam en Michiel: bedankt voor jullie geloof in me en voor jullie onvoorwaardelijke steun! 
About the author 
Boukje Annemarie Cornelia van Dijk was born on 30 May 1974 in "s-Hertogenbosch, The Netherlands. She completed secondary school (VWO) at the Jeroen Bosch College in "s-Hertogenbosch in 1995. In 1993, during secondary school, she also obtained a diploma from Dover High School, Dover, Delaware, USA where she studied for one year. She started her studies Biomedical Health Sciences at the Radboud University Nijmegen (formerly Catholic University Nijmegen) in 1995. As part of her training, she fulfilled three internships. The first was carried out at the laboratory of the department of Pathology, Radboud University Nijmegen Medical Centre, in which an alternative formation pathway of the protein angiostatin in colon carcinoma cancer cell lines was investigated. The second internship concerned a survey on knowledges, attitudes and perceptions of water, diarrhea and hygienic practices and was performed at The Medical Entomology Research and Training Unit/Guatemala, a CDC field office located at the Universidad de Valle in Guatemala. She fulfilled her graduation project at the departments of Epidemiology and Urology, Radboud University Nijmegen Medical Centre, where she carried out a case-control study on alcohol intake, alcohol dehydrogenase and the risk of bladder cancer, which resulted in a publication. After obtaining her MSc degree in Biomedical Health Sciences in 2000, she started her $\mathrm{PhD}$ project at the department of Epidemiology, Maastricht University. This project was performed in cooperation with the departments of Urology and Pathology, Radboud University Nijmegen Medical Centre. Her tasks included the collection of paraffin material from kidney (and prostate) cancer cases from pathology laboratories throughout the country, analyzing obtained data and presenting and publishing the results of these investigations. These results have been described in the present thesis. Since June 2005 , she has been working as a researcher, investigating the subject of ovarian cancer at the department of Epidemiology, Maastricht University. She will start her new job as a postdoctoral fellow at the department of Clinical Chemistry, Radboud University Nijmegen Medical Centre in February 2006, and will be sent on secondment on a part-time basis to the department of Epidemiology and Biostatistics, Radboud University Nijmegen Medical Centre. 